\title{
The Royal
}

Botanic Garden

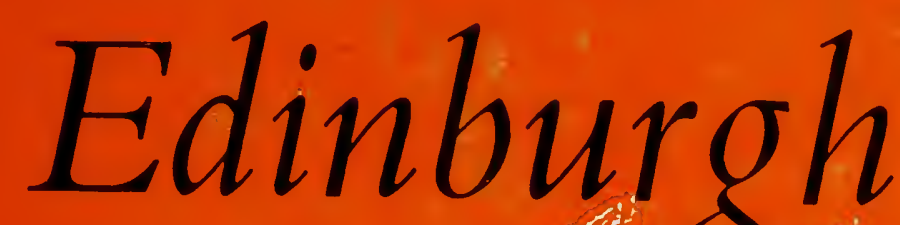

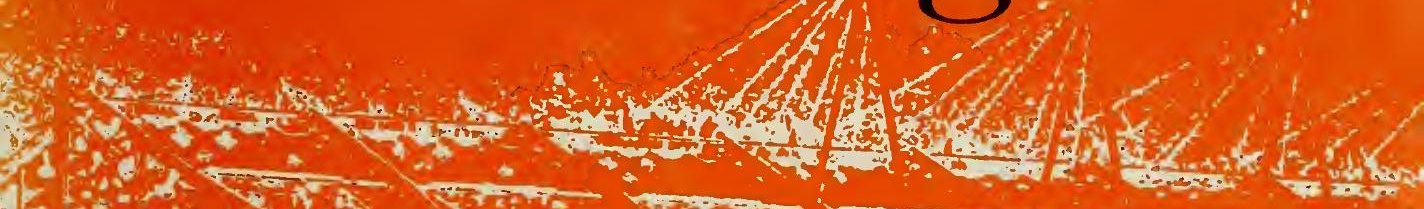
ifis ${ }^{2}$

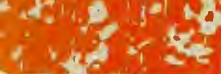
3. (6) (3) inton -

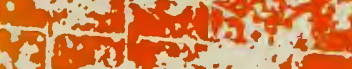
(n) tos $\rightarrow \sin 2$ 5.t.

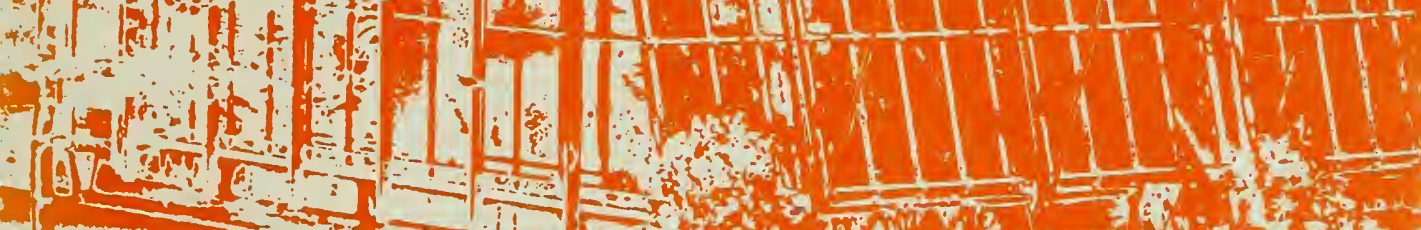

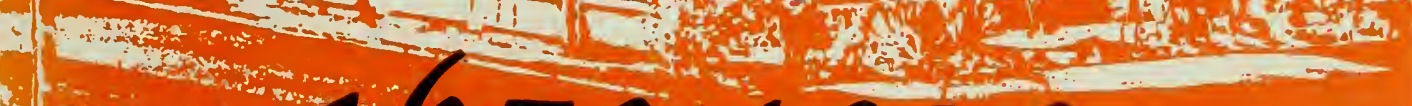
4 
As unfolded by the authors of this informative and well-documented volume the story of Edinburgh's Royal Botanic Garden becomes more than the story of an old foundation which now celebrates its tercentenary. It tells of the lives of a long line of botanists, eleven Professors in all, from the difficult and turbulent days of James Sutherland down to the more spacious times of William Wright Smith, all of them engaged in botanical teaching, and all of them, with varying accents, expounding the science of botany in College and University and in the field excursion. It tells also of the progress of botany during three centuries; of the exploration of the Scottish flora; of the work and careers of notable gardeners; and of the art and science of gardening itself. 

H

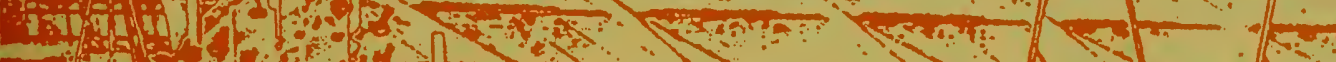

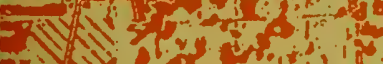

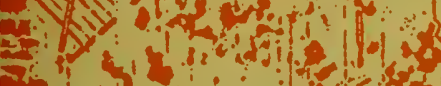

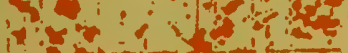

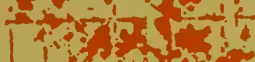

1 1.

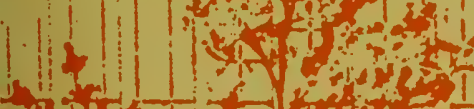
the

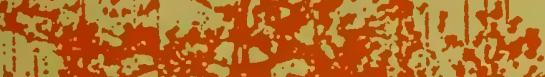

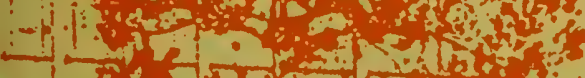
git 3 -

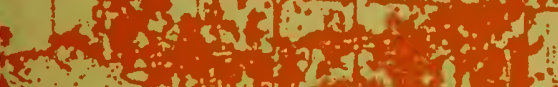

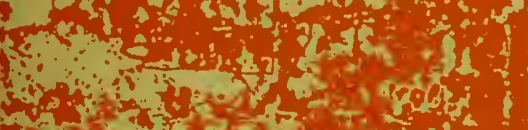

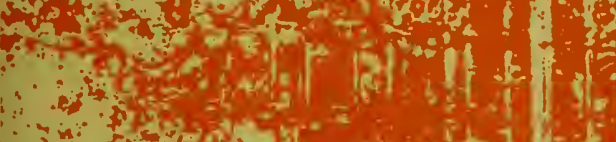

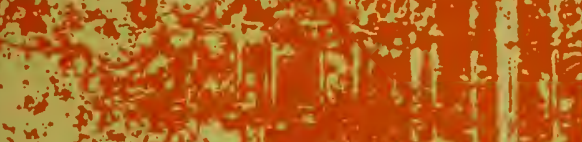
.

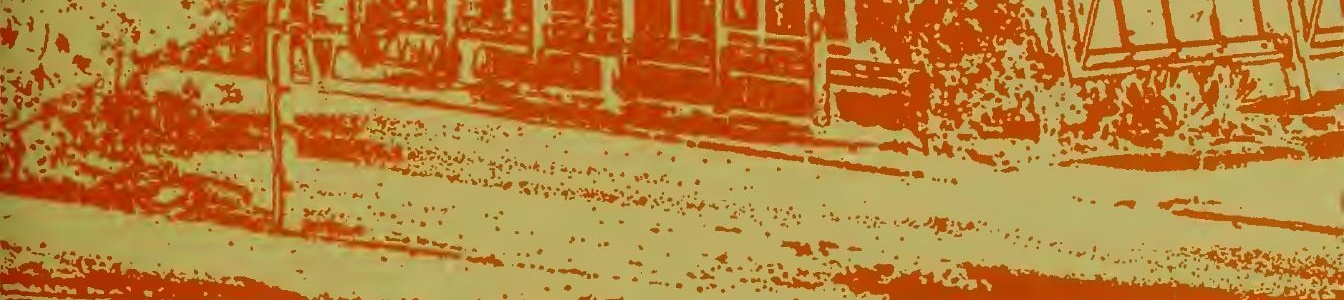
(1)

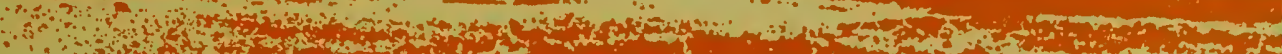

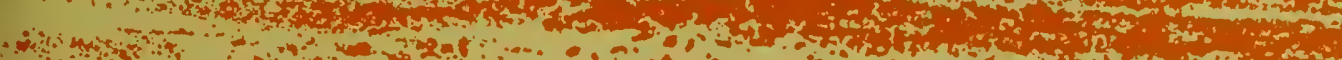

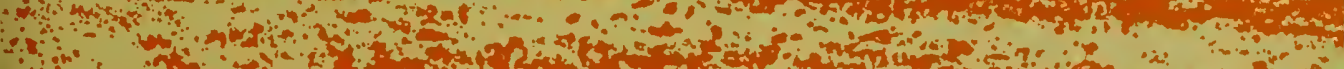
a $\because 2 \pi$ o 
PfP 3 
THE ROYAL

BOTANIC GARDEN EDINBURGH

$$
\text { I } 670 \text { - I } 970
$$






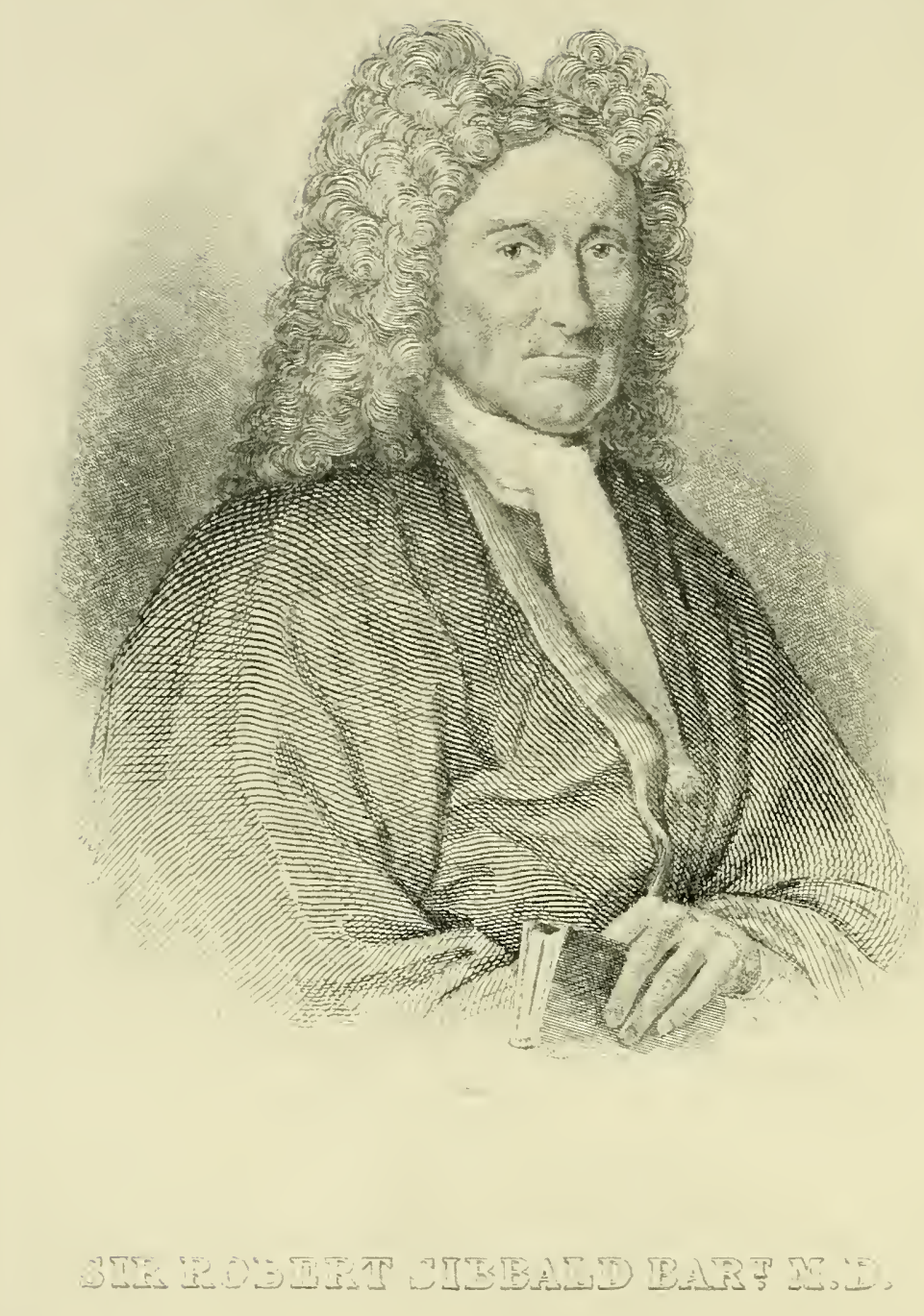

Sir Robert Sibbald (1641-1722)

One of the founders (with Sir Andrew Balfour) of the Garden 
DEPARTMENT OF

AGRICULTURE AND FISHERIES FOR SCOTLAND

\section{The Royal}

Botanic Garden Edinburgh I670-I970

Harold R. Fletcher, William H. Brown

EDINBURGH

HER MAJESTY'S STATIONERY OFFICE I 970

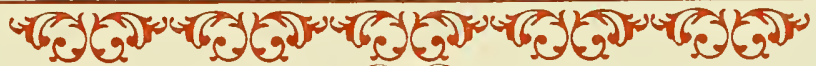




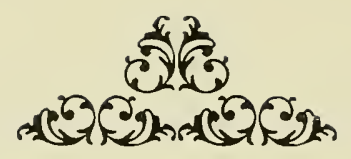

\section{Dedicated}

to all those who in many

capacities have given great service to the

Royal Botanic Garden Edinburgh

and yet are not mentioned

in the following

pages

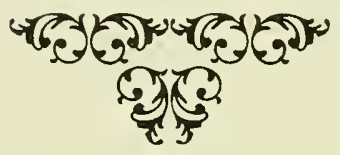

RBGE 5

FLETCHER, H.R.

The Royal Botanic $\mathrm{Ga}$

BPPI'3 $r b$ 


\section{Preface}

IT WAS NOT WITHOUT OPPOSITION THAT TWO EDINBURGH physicians, dissatisfied with the state of medicine in the city, decided to establish a Physic Garden for the cultivation of medicinal and other plants. The site which they secured was a small plot of ground not far from Holyrood Abbey and with the assistance of James Sutherland, the first Intendant of the Garden, the adventure proved entirely successful. It happened in 1670 and neither Andrew Balfour nor Robert Sibbald, the two eminent doctors responsible for the scheme, nor their gardener, could have foreseen that a small plot, measuring scarcely 180 square yards, was to be the precursor of the great Botanic Garden which now occupies an extensive site at Inverleith and of which Edinburgh is justly proud.

Within five years of the original foundation, the collection of plants had so increased that a second garden became necessary and in 1675 new ground was found adjoining Trinity Hospital, not far from where Waverley Station now stands. Here the Garden remained for almost 90 years, serving both for experiment and the supply of specimens to students of medicine. As demands increased so did the need for more space and in 1763 the Trinity Hospital Garden was transferred to a larger site of about five acres off Leith Walk. The final move to Inverleith was made in I823. Thus, step by step, there has gradually evolved the magnificent Botanic Garden of today, a garden now covering 75 acres of great variety and of immense horticultural interest and value.

In an essay entitled 'Garden Ideas', Lord Kames, a learned lawyer and notable land improver of the 18 th century, gave it as his opinion that 'good professors are not more essential to a college than a spacious garden, which ought to be formed with the nicest elegance, tempered with simplicity, rejecting sumptuous and glaring ornaments'. Successive Professors of Botany at Edinburgh were fortunate in having at their command all those resources which a botanic garden can provide and without which they might possibly have found it less easy, whether good professors or not, to give instruction to the students under their charge. In the I7th century botany was 
still linked to medicine and to the herbalism of medieval times. Not a few of the Professors were also Professors of Medicine and a long time was to elapse before the two disciplines became finally separated.

As unfolded by the authors of this informative and welldocumented volume the story of Edinburgh's Royal Botanic Garden becomes more than the story of an old foundation which now celebrates its tercentenary. It tells of the lives of a long line of botanists, eleven Professors in all, from the difficult and turbulent days of James Sutherland down to the more spacious times of William Wright Smith, all of them engaged in botanical teaching, and all of them, with varying accents, expounding the science of botany in College and University and in the field excursion. It tells also of the progress of botany during three centuries; of the exploration of the Scottish flora; of the work and careers of notable gardeners; and of the art and science of gardening itself.

It must suffice to mention a few landmarks and a few outstanding names. The early success of James Sutherland, first as gardener and later as Professor of Botany, gained for him a reputation for skill and learning which travelled far beyond Scotland. His immediate successors were less renowned, although at times they had their exciting moments, but after the appointment of Professor Hope in I76I and the establishment of the Garden at Leith Walk, there followed a period of marked activity, John Hope being a stimulating teacher and a skilled experimenter. He was succeeded by Daniel Rutherford, who was unfortunate in several of his head gardeners, among them George Don, the Forfar botanist, better known for his exploration of the Scottish hills in search of alpines than for his ability as a gardener. The time was to arrive later, however, when the Edinburgh Garden became famous for its great rock garden and collection of rock garden plants.

With the arrival of William McNab in I8Io, one of Scotland's greatest gardeners took charge and to him fell the task of transporting and transplanting the whole collection of plants, large and small, from Leith Walk to Inverleith, an undertaking completed with the utmost skill and with the loss of scarcely a single plant. Three years before this historic event, in 1820 , Robert Graham had been appointed to the Chair of Botany, and in the midst of heavy teaching and administrative duties he found time to encourage local botanists and to play a part in the founding of the Botanical Society of Edinburgh, of which in 1836 he was elected its first President.

At Inverleith the boundaries of the present Garden are much wider than those of 1823 , notably by the incorporation of a large arboretum, and from I845 until 1956, a period of one hundred and eleven years, 
four men reigned supreme as Professors of Botany and Regius Keepers of the Garden. They were John Hutton Balfour, Alexander Dickson, Isaac Bayley Balfour and William Wright Smith; and of these four the greatest was Bayley Balfour. On the secure foundations laid by his father and by Dickson he proceeded at once to make them more secure and like his father before him he held the reins for over thirty years. Chapters I6 and I 7 of this book speak fully of his achievement and of his reputation as botanist and horticulturist. At the same time we should not forget his powers as a teacher. His many pupils, and I was privileged to be one of them, owe him more than we possibly realize.

During the regime of William Wright Smith several outstanding advances were made, including alterations to the woodland area, the formation of peat and heath gardens and, farther afield, the establishment of the Younger Botanic Garden at Benmore, Argyll, the general direction of which is based on Edinburgh. As Wright Smith was quick to realize, the milder and wetter conditions of the west would be favourable for the cultivation of many plants which tend to suffer in the drier and more rigorous climate of the east, and from Edinburgh vast quantities of material, especially rhododendron, poured into Benmore.

When Dr H. R. Fletcher succeeded to the Regius Keepership in 1956, a new era for Botany in Edinburgh was about to begin. For a long time the posts of Regius Keeper of the Botanic Garden and the Professor of Botany in the University had been held by one and the same person. That old tradition was broken and a new arrangement came into being involving the separation of the two appointments. Academic botany found another home, while at Inverleith new enterprises were commenced almost at once and plans were soon prepared for modern buildings to replace those that were old and no longer adequate. Meanwhile, the famous garden at Logan in Galloway, with its remarkable collection of plants, was brought under the care of the Regius Keeper, and at Inverleith, among numerous alterations and developments, there calls for special mention the entirely new and attractive Demonstration Garden, which replaces the old outworn 'Order Beds' and provides an unusual feature of great interest and much educational value. Equally impressive, but in a different way, is the imposing new building which provides accommodation for an invaluable botanical library and herbarium of nearly two million specimens; and, more recently, new and spectacular glasshouses of unique design have been built to provide effectively controlled environments for a great variety of plants from many different parts 
of the world. Here, indeed, one can see plant ecology translated into horticultural practice on a grand scale.

All this and more is on view at Inverleith, and to explore the Royal Botanic Garden of today, the descendant of Robert Sibbald's little plot at Holyrood, is to be rewarded with far more than a passing glimpse of the fascinating world of living plants. As a tribute to all members of the staff who, by hard endeavour, have made it possible, this Preface has been written.

J.R. MATTHEWS

Banchory

January 1970 


\section{fie

\section{Contents}

List of Illustrations

page $\mathrm{xi}$

Introduction

xiii

PART ONE: MATERIA MEDICA AND BOTANY

I Andrew Balfour, Robert Sibbald and Patrick Murray 3

2 James Sutherland

3 William Arthur

4 Charles and George Preston

5 Charles Alston

Interlude to Parts One and Two

PART TWO: BOTANY AT LEITH WALK

6 John Hope

7 Daniel Rutherford and His Gardeners

8 William $\mathrm{McNab}$ 
PART THREE: BOTANY AT INVERLEITH

9 Robert Graham

Io The Botanical Society of Edinburgh

II John Hutton Balfour

I2 J. H. Balfour, James $\mathrm{McNab}$ and John Sadler

I3 The Garden in 1870

I4 The Working Men versus The Sabbath Alliance I64 Interlude to Parts Three and Four

PART FOUR: UNDER THE CROWN

Is Alexander Dickson and His Curators

I6 Isaac Bayley Balfour

I7 Bayley Balfour and the Sino-Himalaya

I8 William Wright Smith

I9 New Buildings

20 The Garden in 1970

Index 


\section{술 \\ (2)}

\section{List of Illustrations}

Frontispiece Sir Robert Sibbald(1641-1722), one of the founders

(with Sir Andrew Balfour) of the Garden

Plates

I John Hope (1725-1786), Regius Keeper of the Garden and King's Botanist 1761-1786

II The old Trinity Hospital, the Physic Garden is in the foreground

III (a) The Garden on the site where now stands Haddington Place, about 1800

(b) Professor Hope's drawings illustrating the sleep movements of clover (i) and Desmodium (ii) and Cassia (iii)

IV (a)-(b) Professor Hope's drawings illustrating the stem of Asperula odorata curving upwards against the force of gravity

(c)-(d) Professor Hope's drawings illustrating the stronger influence of light over gravity

V(a) William McNab (1780-1848), Curator of the Garden 1810-1838

(b) Robert Graham(1786-1845), Regius Keeper and King's, later Queen's, Botanist 1819-1845

(c) John Hutton Balfour (1808-1884), Regius Keeper and Queen's Botanist 1845-1879

(d) James McNab (1810-1878), Curator 1849-1878

VI (a) The Exhibition Hall of the Royal Caledonian Horticultural Society which served as the Herbarium of the Botanic Garden 1864-1964

(b) John Sadler (1837-1882), Curator 1879-1882

(c) The planting machine, originally invented by William McNab and modified by James $\mathrm{McNab}$

VII (a) The state in 1854 of the Palm House opened in 1834

(b) The Palm House opened in 1858

VIII Part of James McNab's famous Rock Garden

IX (a) Alexander Dickson(1836-1887), Regius Keeper and

Queen's Botanist 1880-1887

(b) Robert Lindsay (1846-1913), Curator 1883-1896

(c) Robert Lewis Harrow (1867-1954), Curator 1902-1931

(d) Adam Dewar Richardson (1857-1930), Curator 1896-1902 
X (a) Isaac Bayley Balfour (1853-1922), Regius Keeper and Queen's, later King's, Botanist 1888-1922

(b) Laurence Baxter Stewart(1877-1934), Curator 1932-1934

(c) Bayley Balfour at his lecture table

XI (a) William Wright Smith(1875-1956), Regius Keeper and King's, later Queen's, Botanist 1922-1956

(b) George Forrest (1873-1932), foremost plant collector in the Himalaya and Western China

(c) John Macqueen Cowan (1892-1960), Assistant Regius Keeper 1930-1954

(d) Roland Edgar Cooper (1891-1962), Curator 1934-1950

XII (a) Edward Edmund Kemp (1910-), Curator since 1950

(b) Harold Roy Fletcher (1907-), Regius Keeper since 1956, and Queen's Botanist since 1967

(c) The Herbarium, Library and Laboratory Building, officially opencd by Her Majesty The Queen, 29 June 1964

XIII Herbarium (top), Library (centre), Laboratory (bottom)

XIV (a) The Rock Garden: the North face

(b) The Rock Garden (compare Plate vin)

XV (a) Exhibition Plant Houses, officially opened by Her Royal Highness The Princess Margaret, Countess of Snowden, 25 October 1967

(b) Giant Victoria Water Lilies

XVI (a) Ferns in the Exhibition Plant Houses

(b) Tree Ferns in the Logan Botanic Garden, Wigtownshire

XVII (a) Cabbage Palms in the Logan Botanic Garden, Wigtownshire

(b) Rhododendrons in the Younger Botanic Garden, Benmore, Argyll

XVIII Cabbage Palm Avenue, Logan Botanic Garden

XIX The Woodland Garden, Royal Botanic Garden, Edinburgh

XX The Avenue at Benmore of the California Big Tree 


\section{(2)}

\section{Introduction}

\section{EDINBURGH IN 1670}

THE EDINBURGH OF I 670 WAS A DENSELY POPULATED CITY closely constricted between natural barriers and the narrow boundaries of its own walls. The Castle Rock rose above the swampy valley that is now Princes Street Gardens and the northern limits of the town were sealed in turn by this marsh, the Nor' Loch which drained it ineffectually, and, north-eastwards, the crags of Calton Hill. In the south, beyond the city walls, few buildings as yet encroached on the open fields. The main thoroughfare was the mile-long High Street and Canongate that ran from the Castle in the west to the Abbey and Palace of Holyrood in the east. A secondary street, the Cowgate, stretched the same distance, scarcely two hundred yards away to the south; while connecting the High Street and the Cowgate were the countless closes and wynds in which almost the entire population had their dwellings with little or no distinction of class or status. Dark and narrow stairs, climbing often to ten or even twelve storeys, gave entry to low-ceilinged ill-lit flats for the most part of little architectural merit and differing from one another only in the number of their rooms and closets. Few concessions were made to comfort or sanitation. The High Strect served also as the city's drain into which the inhabitants daily cast the ordure of each household and the 'flowers of Edinburgh' as the more charitable referred to the resulting noisomeness had never known a garden.

Notwithstanding the filth of the streets and stairs, it was a picturesque enough town with no less colourful inhabitants especially when augmented in the years before the Union of the Parliaments by the nobility and their retainers who periodically descended on the capital in attendance on the nation's business. Political and economic changes were soon to alter its character but 
at this time, which many claimed as Edinburgh's most glorious age, the social structure of the city, though racked not infrequently by the same turmoil that afflicted the rest of the land, was comparatively settled. A shopkeeper thought nothing of sharing a common stair with a noble customer or a judge of being neighbour to clerks or artisans.

Desirable as this social stability may have been it reflected stagnation in other directions. The nation was torn by religious strife. In I649 Charles II had first been proclaimed King at the Cross of Edinburgh and although before his coronation at Scone in 1650 he had signed the Solemn League and Covenant, his accession brought not the religious toleration so earnestly desired but a series of insurrections that were to culminate in 'the Killing Time' and lead in the end to the Revolution being hailed as loudly as had the Restoration before it. The religious persecution with its 'Test' and 'Indulgences' is no part of this story except for its disastrous influence on the progress of education, particularly as it affected the Universities. Official episcopacy had been introduced in $166 \mathrm{I}$ by an 'Act for the restitution and re-establishment of the ancient government of the church by archbishops and bishops' that resulted not only in the wholesale ejection of the Presbyterian ministers from their charges but the exclusion from teaching posts of all who failed to conform. Most of the occupants of the chairs of the universities were, as Graham has described them, little more than 'undistinguished Episcopal ministers up to the Revolution, and, after that .... equally uncultured Presbyterian ministers who had got a haphazard education at home or in Holland, to which they had taken flight' so that 'the seats of learning were long empty of learning, and the centres of highest national education could boast of little philosophy and of less science'. I Half a century was to pass before the situation improved. Teaching was in the hands of the Regents, teachers who recruited their pupils as they came up to the university and thereafter saw them through their three or four year course, introducing them successively to each of the branches of knowledge in which they had to show competence before being admitted to their laureation. Small wonder then that while such an educational process had currency few, if any, could show distinction in any single subject. Accommodation matched the standards of the instruction, so inadequate for their purpose were university buildings. Students were encouraged to lodge within their precincts but most

I H. G. Graham, THE SOCIAL LIFB OF SCOTLAND IN THB EIGHTEENTH CENTURY, (1928), p.448. 
of the mean chambers erected for their residence were pressed into use as classrooms to be filled day in and day out with relays of aspiring audiences.

Higher education moreover was very general in character and apart from the added barrier to learning created by the fact that all instruction was imparted in Latin for which few students were adequately prepared, vocational subjects, training in the professions of law and medicine in particular, were totally excluded. Reform was slow in developing but when the first moves were made by the medical profession, approval was far from universal. Sir John Lauder of Fountainhall in his HISTORICAL NOTICES OF SCOTISH AFFAIRS, I66I-I688 records on 27th March I685 'The Magistrats of Edinburgh, on a letter from the Chancelor, installs Doctor Sibbald to be Professosor of Medicine in the College of Edinburgh; but the salary is not yet condeschended upon .... Ther would be more use for a Professor of Law in Edinburgh, as to which the Advocats have made severall proposealls. Ther are now added to Sibbald the 2 other Doctors, viz., Pitcairne and Hacket'. ${ }^{1}$

But if the level of general university education was low compared with continental centres, the medical arts were more strikingly decadent. The Incorporation of Surgeons and Barbers, by the late seventeenth century, was a venerable institution. Barbers not only shaved but performed operations. The rules of the College of Surgeons and Barbers in I 505 required that all must "knaw anatomie, nature, and complexion of everie member of the humanis bodie, and in lykewyse knaw all the vaynis of the samyn, that he mak Flewbothomia in dew tyme, and alseu that he knaw in quilk member of the signes hes domination for the tyme'. A century and a half later methods and techniques had made little advance and practice remained primitive in the extreme. By 1670 the bond between surgeon and barber was strained to breaking point and in Scotland a new profession of Chirurgeon-Apothecary evolved to act as general practitioner to the exclusion of the barbers who were left to exercise their more mundane craft. The change however was little more than one of nomenclature and training requirements continued to be as haphazard as before. Apprenticeships normally extended only over a three year period and cases are recorded in which for the first two of the three years the indentured bound himself not to attend any professor of medicine, anatomy, surgery or materia medica. Indeed instruction by anyone but his master was the exception. His appearance before the Incorporation at the end

I Pitcairne and Hacket were not in fact appointed to chairs until gth September r685. 
of his apprenticeship, to be questioned on the theory and practice of his profession, was cursory and licence to practise was rarely if ever withheld.

Appalling as this situation was, the physicians who practised fared even worse. They had neither professional organization nor formal qualifications and should they be so bold as to step beyond the practice of physic and venture to encroach on the province of the surgeon they were required to pay fees and qualify as surgeons before the Incorporation. Nor was thcir art any more sophisticated than the practice of their brothers. Their concoctions were often barbaric, owing nothing to science or skill. Long after the establishment of their own College, as late as 1737 , in the third edition of the Edinburgh Pharmacopoeia, spiders' webs, gizzard of hen, spawn of frogs, and juice of woodlice still figured large. Even the eminent Pitcairne, formerly a professor at the greatest of the European medical schools, Leiden itself, could reconmmend mercury and broth with earthworms, adding powder of human skull!

It was incvitable therefore that the state of every branch of medicine was the despair of the discriminating. The only mystery is how, from this sea of ignorance, there emerged, as Eric Linklater so aptly records, 'the agreeable fact that botany, the gentlest of sciences, made its debut in Edinburgh in the dark and tormented years of the seventeenth century'.

I Eric Linklater, EDINBURGH, (I960), p.5I. 


\section{PART ONE}

\section{Materia Medica and Botany}

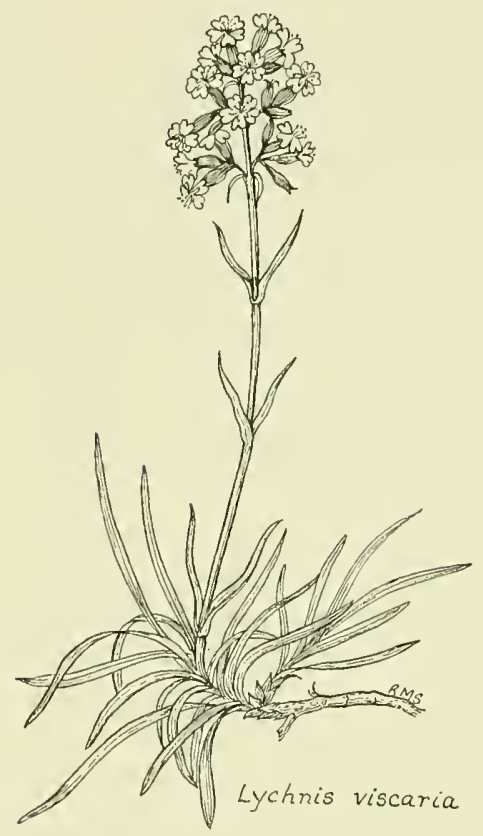





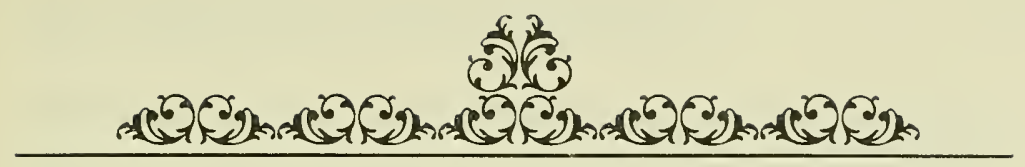

CHAPTER ONE

\section{Andrew Balfour, Robert Sibbald and Patrick Murray}

THE INFLUENCE OF A GRADUATE OF THE UNIVERSITY OF Aberdeen on two Edinburgh physicians, Andrew Balfour and Robert Sibbald, was indirectly responsible for the establishment of a Botanic Garden in Edinburgh.

The Aberdonian was Robert Morison, who, born in I620, graduated MA at the age of eighteen. Intended by his parents for the Ministry, the English Civil War, rather than the Ministry, claimed his interest and energies, and he became involved in the Royalist cause against Cromwell, took up arms, and at the battle of the Brig o' Dee received severe head wounds. On his recovery, like many another fighting this cause, he fled to France where fortune smiled upon him. He took up the study of plants under Robin, botanist to the King, quickly attracted attention by his abilities and in I650 was appointed director of one of the most renowned gardens in Europe, that of the Duke of Orleans, the uncle of the King, at Blois. Here he stayed until the Duke died in I660. By this time the House of Stuart had been restored to the throne of England and Morison, accepting Charles II's invitation to return, was appointed King's Physician and Professor of Botany and Director of the Royal Gardens. Thus it was until I669 when Morison became the first Professor of Botany in the University of Oxford and published his first botanical work, the PRAELUDIA BOTANICA. In this he outlined the rudiments of a system of plant classification which he claimed to be his own but which was in fact in large measure a revival of the system of the Italian botanist 
Caesalpino of almost a century before based on the structure of the fruit and seed.

Of the two Edinburgh physicians, Andrew Balfour and Robert Sibbald, the former was the senior and was the youngest son of Sir Michael Balfour of Denmiln, Fife, where he was born on I8th January I630. On completing his elementary education he proceeded to St Andrews University where he studied philosophy under his brother, Sir James Balfour, an accomplished scholar no less than thirty years his senior. It was at St Andrews that he graduated MA and where his interest in plants led him to study medicine. In pursuit of medical studies he journeyed to London in I650, met the great Harvey, discoverer of the circulation of the blood, but was principally the pupil of Sir John Wedderburn, Physician to the King. In I65I he travelled to France and for a time stayed with Morison at Blois and saw Morison's work in the Duke of Orleans's garden. Shortly afterwards he moved to Paris where he took up residence and assiduously applied himself to his medical education, attending the lectures of Riolanus, Moreau, Guenotius de la Chamble and Patin, working in the public hospitals, and spending much time in the Paris Botanic Garden.

There then followed an interlude during which time he travelled through France in the company of one Watkinson-Pelior with whom he returned for a short time to Yorkshire. However he was soon back in France, at Caen, where he attended the University and obtained the degree of Bachelor in Medicine for his dissertation De Venae Sectione in Dysenteria, and on 20th September I66I was awarded a doctorate.

Shortly afterwards he returned to London where, possibly through the influence of Morison, he was quickly admitted to the highest circles for Charles II nominated him to the post of Governor to the young Earl of Rochester with whom he undertook a grand tour of Europe returning from Italy in 1667 . Rochester was later to acknowledge his indebtedness to Balfour to whom 'next to his parents, he thought he owed more than to all the world'.

In all, Balfour spent some fifteen years abroad, continually observing not only the natural history of the European countries he visited but also their antiquities, laws and customs. And he was forever collecting. On returning to St Andrews he brought with him what has been described as the best library, especially in medicine and natural history, that had until then appeared in Scotland. He had assembled a collection of antique medals, modern 
medallions, pictures, arms, vestments, ornaments, as well as numerous mathematical and surgical instruments. With the latter he performed dissections in surgery previously unknown in Scotland. To complement these medical and surgical appliances he brought a complete range of the 'simples' of materia medica besides a large collection of plants, animals and fossils.

St Andrews did not contain him for long; in I667, or early in I668, he moved to Edinburgh, entered into medical practice, and enjoyed the friendship of the leading figures in Edinburgh society. Freely he made available his library and museum to all who wished to profit by their use, and freely he dispensed advice and introductions to those who intended to travel abroad. Adjoining his house in Edinburgh, the location of which has not been established, he furnished a small botanic garden with plants which he grew from seeds received from his correspondents both in Britain and in Europe; from Morison now at Oxford, Watts in London, Marchant in Paris, Hermann in Leiden, and Spotswood at Tangiers.

As assistant and colleague Balfour had Robert Sibbald (Frontispiece) who was born in Edinburgh on Isth May I64I in a house 'neer to the head of Blackfriars Wynd upon the left syde'. Whilst Sibbald was still a child the family had moved to Dundee, but he returned to Edinburgh for his education at the High School and at the University where he graduated in 1659 at the age of eighteen. Determined to study medicine and thus to follow in the footsteps of his uncle, Dr George Sibbald of Giblestone, who had achieved considerable eminence, he went abroad, first to Leiden, then to Paris, and finally to Angers where he obtained the Patent of Doctor in I66I for a dissertation Disputatio Medica de Variis Tabis Speciebus. He returned to Edinburgh at the end of October of the following year and straightway entered into practice as a doctor.

$\mathrm{He}$, rather than Balfour, took the initiative in an attempt to organise the medical profession and, as part of a larger scheme, set about acquiring land for the establishment of a physic garden. However, according to John Walker, ${ }^{\mathrm{I}}$ to Balfour is due much of the credit for the founding in I68I of the College of Physicians of which Sibbald was elected its second President in I684 and Balfour its third, the following year. ${ }^{2}$ There appears to have been no rivalry in the professional relationships of the two friends; in fact from

I ESSAYS ON NATURAL HISTORY AND RURAL ECONOMY, (ISO8), p.36I.

${ }^{2}$ Sir Archibald Stevensone was the first President, elected on 8 th December I68I. 
the evidence of their works there existed a remarkable harmony of purpose which led to the achievement of most of their aims.

Sibbald was appalled at the state of medicine in Edinburgh. The ignorance of the chirurgeons and apothecaries was greater than anything he had seen on the continent and quacks and mountebanks were everywhere. There was neither pharmacopocia nor standard drugs, and much of what was passed off to unsuspecting patients was inferior and ineffectual. To remedy this Sibbald was led to take up the study of the indigenous plants of Scotland and to establish a private garden in which he cultivated medicinal herbs. About this time he became acquainted with Patrick Murray, the Laird of Livingston in West Lothian, introduced him to Balfour, and travelled frequently to Livingston to see the remarkable collection of plants which Murray had assembled there.

Murray was a young nobleman, with a comfortable fortune, whose main interest lay in natural history. At Livingston he had in cultivation nearly a thousand plants which he had acquired in his travels throughout Britain and from seeds sent to him by foreign botanists. Much impressed by Balfour's accounts of his residence abroad he determined to travel himself and thereby see new plants with which to increase his collection. Thus he departed for the continent in September 1668 travelling throughout the whole of France. However, on his way to Italy in August or Septenber I67I he contracted a fever and died at Avignon. Prior to Murray leaving for Europe Balfour wrote a number of letters to him but, in spite of their general interest, consistently refused to publish them during his own lifetime. In I700, however, they were published anonymously as LETTERS TO A FRIEND, printed on the authority of Balfour's son and dedicated to the Earl of Murray, close friend of his father. The letters are an account of Balfour's experiences and contain advice to Murray on what to look out for in the course of his journeys. And, of course, they mention besides the curiosities, every garden Balfour had visited. From the point of view of this narrative Murray's real significance lies in the fact that his garden was the main source of supply of the plants which stocked the botanic garden which Sibbald and Balfour established in 1670 .

In this year the two physicians obtained from John Brown, gardener of the North Yards in Holyrood Abbey, the lease of an enclosure at St Anne's Yards measuring $40 \mathrm{ft}$ by $40 \mathrm{ft}$. It was the practice of the Hereditary Keeper of Holyroodhouse to let the area known as St Anne's Yards, lying to the south of the 
Abbey, to market gardeners, and Brown was one such tenant. By what they procured from their respective private gardens and from Murray at Livingston, as well as by 'what they brought in from the country', Balfour and Sibbald quickly assembled in their enclosure at Holyrood a collection of between eight and nine hundred plants. However, the plants had to be maintained and neither of them had the time for this. Fortunately they had made the acquaintance of James Sutherland of whose origins nothing is known but who is described as 'a youth, who, by his owne industry, had attained great knowledge of the plants and of medals'. Sutherland was appointed to the charge of the garden whilst Balfour and Sibbald endeavoured to persuade the physicians in the town to contribute something each year to the cost of its maintenance and to the importation of foreign plants. At first they met with nothing but opposition from the Chirurgeon Apothccaries who dreaded that the garden might lead to the establishing of a rival body to their own, might lead in fact to a College of Physicians, which would break their monopoly of medical practice. Balfour's diplomacy, however, ultimately won them round so effectively that they went to the extent of assisting in the acquisition of a lease of another piece of land for botanic garden purposes.

A new garden was made necessary by the very success of the first which soon became too small for the growing collection. Accordingly Balfour, supported by a majority of the medical profession, petitioned the Town Council to lease to Sutherland the land adjoining Trinity Hospital which lay at the mouth of the Nor' Loch on a site now occupied by the east end of Waverley Station (Plate II). In this the Council concurred and duly recorded its decision in a minute dated 7 th July 1675 :

Edinburgh. The seaventh day of Jully, I675.-The Councill Agrees to Sett Intack to Mr. James Sutherland herbalist the yairds and gairdiners hous pertaining to the trinitie Hospital for nyntene years upon the conditions of the former Sett to the last taxman John Craig and upon the condition that he shale menteine the roof of the gairdeners house and dyks of ye yeard dureing the space of the tack And that the Mrs of the hospitall shale have access to ye yairds to walk in ....

The layout of this second garden, later to become known as the Physic Garden and also sometimes confusingly referred to as the

I Sibbald's mS мнмоirs. 
Botanic Garden, was fully recorded by Sibbald in his scotia ILlustrata (1684). Writing in I682, he described it as being about $300 \mathrm{ft}$ from east to west and $190 \mathrm{ft}$ from north to south. It was divided into six rectangular plots, three on each side of the canal which was the drainage channel of the Nor' Loch and which was to assume a certain importance later. The contents of the first and second plots on the north side were formally arranged in beds according to the order in the PINAX of the Swiss botanist Caspar Bauhin, and were accurately divided into genera and species. The third plot on the north, divided from the other two by a privet hedge, was a flower garden with the more showy plants arranged in beds. These three areas sloped from the north boundary wall to the central channel and therefore had an excellent southern exposure. The other part of the garden was somewhat overshadowed by the city wall and was flatter, but, like the rest, was also divided into three, with beds, walks and paths. The first of these-the fourth plot-lying to the north near a wall, was organised as a place of instruction for medical students and plants used in medicine were arranged in beds in alphabetical order as in Dispensaries. The fifth plot contained a pond for aquatic plants as well as a small nursery, whilst the sixth section, divided from the last by another privet hedge, was planted as an arboretum with many kinds of tree and shrub. Along the enclosing walls some of the rarer plants were grown under the protection of bell-shaped glasses and small frames. The walls were also covered with shrubs. Sibbald estimated the number of plants in the Garden at approximately two thousand, more than double the number at the St Anne's Yards plot which now apparently was abandoned to its original tenant, for nothing further is heard of it.

How much Balfour and Sibbald were involved in the supervision of Sutherland and the Garden is not at all clear, although it would appear that once the Garden was successfully established they were content with providing encouragement and soliciting patronage on Sutherland's behalf. Balfour's reputation as the best qualified physician in Edinburgh remained unchallenged until his sudden death which occurred on 9th January I694 whilst he was walking in the High Street. Twelve years earlier, his supremacy, and that also of Sibbald, was recognised when at Holyrood both were knighted by the Duke of York. Although Balfour wrote little in his lifetime he was credited with an immense store of knowledge and experience that, being exerted always for the public good, won 
for him not only fame but honour. Nor was his wisdom entirely confined to medicine and natural history, for he was said, by $\mathrm{Dr}$ John Walker, to have been responsible for introducing the papermaking industry to Scotland.

Balfour's library of 3,000 volumes, of which a catalogue was published in I695, was sold after his death. His museum he left to the University where apparently it lay neglected until 1782 when the remnants were gathered together by Walker. A catalogue of this museum which contained many items contributed by Sibbald was published in 1697 under the title AUCTARIUM MUSAEI BALFOURIANI E MUSAEO SIBBALDIANO. It is more than a mere list. It describes the specimens in some detail and gives notes on their provenance. Walker clearly thought highly of the collection and lamented its dilapidation.

Sibbald recorded Balfour's achievements in MEMORIA BALFO URIANA, a slim memorial volume published in Latin at Edinburgh in I699. He outlived his colleague by a quarter of a century. In I685 he was appointed the first Professor of Medicine in the Town's College, but only a few months later was forced to resign from this appointment and from the Royal College of Physicians on account of his conversion to Roman Catholicism. This involved bim not only in loss of office but in actual physical danger, for he so incurred the displeasure of the citizens that he was hounded from his house by a mob that threatened him with assassination. He escaped, however, to the Sanctuary of Holyrood whence he fled to London where he soon became disenchanted with his new faith, reverted to Protestantism and returned to Edinburgh the following year. Although quickly re-elected a Councillor of the College of Physicians, he seems to have taken little part in its future development, or to have practised to any great extent, concentrating instead, perhaps, on his literary work.

Although one anonymous account now in the library of the Royal Botanic Garden, which has been attributed to John Rutherford, Professor of Practice of Physick at Edinburgh and the contemporary of Charles Alston, ${ }^{\mathrm{I}}$ states that Sibbald died in I7IS, R. P. Ritchie in his history of the Royal College of Physicians writes:2 'A man of pure intentions, of amiable disposition, and of a generous temper', he died in his eighty-second

I See page 40.

2 R. P. Ritchie, THE EARLy Days of THE ROYAll COLledge of PHisitIANS, EDINBURGH, (I899). 
year 'in Bishop's Land, beside Carubbers Close, Edinburgh', on 9th August 1722.

Sibbald was much more of an author than was Balfour, having published his first work, NUNCIUS SCOTO-BRITANNUS, in I683, and was even before that time so well known for his literary talents that Charles II commissioned him to prepare a general description of the entire country and nominated him King's Physician, Geographer-Royal and Natural Historian. The result of this commission was SCOTIA ILLUSTRATA, published in I684, followed by another edition in 1696. The first part deals with geographical and archaeological matters whilst the second part enumerates nearly 500 plant species as well as colour forms and varieties. Some of the plants are rather difficult to identify, whilst many of the species are not really natives of Scotland at all. Only two species are recorded for the first time as British, the alpine Sibbaldia procumbens, named after Sibbald of course, and the Lovage Ligusticum scoticum. Even so there are many references to plants in the neighbourhood of Edinburgh the most interesting of which are the Catchfly Lychinis viscaria, discovered by Willisel in 1670 , and the Forked Spleenwort fern Asplenium septentrionale-both on Salisbury Crags, where they still grow.

Sibbald left to posterity a manuscript autobiography, of which at one time two copies existed; one has been lost without trace but the other is preserved in the National Library of Scotland. It was published first in I834 in Maidment's ANALECTA SCOTICA and republished separately in an annotated version in 1932 by F. P. Hett. Its republication more than two centuries after his death was a becoming tribute to the memory of a remarkable man. 


\section{atis}

\section{CHAPTER TWO}

\section{James Sutherland}

WITHIN EIGHT YEARS OF HIS BEING APPOINTED 'INTENDANT' Sutherland published a list of the plants in the Physic Garden at Trinity Hospital, the HORTUS MEDICUS EDINBURGENSIS of I683, 'a catalogue of the plants in the Physical Garden at Edinburgh containing their most proper Latin and English names'. The work is dedicated to the Lord Provost of Edinburgh, The Rt Hon George Drummond of Miln-Nab and 'humbly kissing your Lordship's Hands' Sutherland says:

My Lord, I shall not here trouble you with any tedious Account of the Garden it Self, it will sufficiently appear to your Lordship, and to all the World, by this Cataloguc, how well it is instructed; and I dare boldly say, comparing it with the Catalogues of other Gardens abroad, it runs up with most of them, either for Number, or Rarity of Plants: it having been my Bussiness these seven years past, wherein I have had the Honour to serve the City as Intendant over the Garden, to use all Care and Industry by forraign Correspondence to Acquire both Seeds and Plants from the Levant, Italy, Spain, France, Holland, England, east and west Indies; and by many painful Journeys in all the Seasons of the year, to recover whatever this Kingdom produceth of Variety, and to cultivate and preserve all of them with all possible Diligence . . . . Neither do I need here to trouble your Lordship with a rehearsal of the Advantages that from this Design accrues to the whole Nation, and more especially to this Place, besides the Ornament thereof; for now it plainly appears that many of these Simples that were wanting here, and therefore yearly brought from abroad, because of their Usefulness in Physick, may now by Industry and Culture be had in plenty at home. And it is evident that the Apothecaries Apprentices could never be competently instructed in the Knowledge of Simples (which necessarly they ought to be) before the Establishing of this Garden; for now they may learn more in one Summer, than formerly it was possible for them to do in an Age. 
The catalogue is an accurate and detailed list which supplements admirably Sibbald's description of the Garden. It includes most of the herbs in common use by the medical practitioners of the day and many of the fruits and vegetables now universally accepted but then very rare. Aiton, in the first edition of HORTUS KEWENSIS (I789), credits Sutherland with the introduction of twelve species new to Great Britain. However, the number of plants which he raised for the first time in Scotland must have been very much greater and included the common larch which he had in his Garden before I683. Although Sibbald, in SCOTIA ILlustrata, states that the plants in the Garden were arranged according to Bauhin's classification, Sutherland claims he has 'disposed the whole Plants according to the most natural and rational Method, and according to the best and latest Authors of Botanie, and particularly our most Learned and incomparable Countreyman Doctor Morison'. No doubt the arrangement was more than once altered.

For his intendantship Sutherland received an annual salary of $f_{20}$, most of which had to be expended on meeting the terms of his lease, and he had from time to time to petition the Town Council and even the Privy Council for further sums which, although granted, at no time amounted to a regular income. On I4th May I684 forty pounds (Scots) was allowed to him for extending the garden to include the Trinity College Kirkyard, and later in the same year, on 24th October, he received a further twenty pounds to subsidise his catalogue. In December I684 the large sum of $£ 2487$ s. 6d. was paid, on Sutherland's behalf, to a Leith shipmaster, James Law, for two years' arrears of fees for the transport of plants from Rotterdam.

Sutherland's official status as intendant was established in $\mathbf{1 6 7 6}$ when the Town Council formally awarded him his salary of twenty pounds, and his post was 'joined with to' the other professions taught in the Town's College. Thus, at this date, he may have been admitted to the teaching body but he had to wait until Ist February I695 for the Council to create for him a Chair of Botany. The minute which records this appointment also awarded him a further salary of ten pounds for planting the College Garden with herbs and other plants, in addition to teaching two days a week in the Town's College. Until this time, therefore, possibly he acted only as demonstrator to Sibbald or Balfour, and certainly in his HORTUS MEDICUS EDINBURGENSIS he makes no claim to any responsibility beyond that of keeping the Garden. 
The planting of the College Garden did not involve Sutherland in the creation of another new garden but in the revival for teaching purposes of a large piece of open ground that had belonged to Kirk-of-Field and which ran along the south and east sides of the College ${ }^{1}$ and extended to the grounds of Blackfriars. Originally it appears to have been a pleasure ground for the Magistrates, Council and the Masters of the College, being recorded in Gordon of Rothiemay's map of I647. However, little is known of its origin and its transfer to Sutherland's custody in 1695 is the earliest occasion on which it comes into prominence. In the course of time it too became known as the Physick Garden, being so-called on Edgar's map of $\mathrm{I}_{742}$, whilst the Trinity Hospital Garden by 1695 was for distinction being referred to as the Botanic Garden. The College Garden was in use for teaching until I724, when once again it was turned to other uses.

Not content with two gardens in February r695 Sutherland undertook the supervision of a third by taking over that part of the Royal Garden at Holyrood known as the King's Garden and there began to cultivate vegetables and medicinal herbs. This garden was quite distinct from the original plot rented from John Brown at St Anne's Yards.

Att Edinburgh, December I2, I695.-Anent the petitione given in to the lords of his Majesties Privy Counsell be Mr. James Southerland Master of the physick gardine shewing that in February last The petitioner hade gott that north yard of the Abbey belonging to the Kings palace wher the great Dyall stands and which is near the Tinnis Court .... And he spared no necessarie expenss to bring it als great a lenth as was possible in so short a tyme haveing had ther this sumer a good cropt of melons and raised many other curious annualls fyne flowres and other plants not ordinary in this Countrie he will also undertake in a few years to have things in alls good order ther as they are about Londone if he be allowed a competencie to.... make .... a green house and a store to preserve orranges Lemons myrtles with other tender greens and fine exetick and forraigne plants in winter ....2

This Privy Council record of I2th December I695 goes on to recommend that in fulfilment of its promise to him he should be reimbursed for his expenditure in putting in good order the North Yard of the Abbey, and be awarded his claim for 'upwards of Ane Thousand punds Scotts besydes four hundred merks'. This third

I Now occupied by the south end of South Bridge and Nicholson Street and South College Street.

2 PRIVY COUNCIL REGISTER, I2th December I695. 
garden, of which Maitland, ${ }^{1}$ quoting Dr Nicolson, ${ }^{2}$ Archdeacon of Carlisle, remarks on its flourishing condition in ${ }^{2} 7{ }^{1} 3$ 'by the skill and industry of the ingenious and worthy botanist', was Sutherland's first step to Royal patronage for on I2th January 1699 he became King's Botanist under a Warrant of William III.

William etc. Forasmuch as wee considering yt Mr James Sutherland has bein att great paines to sett up a physick Garden att Edinburgh and yt he hath for some tyme taught wt. good success ye knowledge of plants and has also brought into good order the garden about our palace of holyroodhouse and wee being willing in consideration yrof and for his further encouragmt. yrin to bestow a mark on him of our royall favor therfore witt yee us to have given granted and disponed Lyke as be these prnts we give grant and dispone to thesd, Mr James Sutherland a yearly pension of fiftie pound ster: dureing our pleasure only to be pd to him out of the first and readiest of our rents revenues customs and casualities whatever our said Kingdome and yt att twa terms in the year Whit: and Martinmas be equall proportions Begining the first terms payt. att Whitsunday next to come and so furth to continue yearly and termly dureing ye space forsd Comanding hereby ye Lords Commissrs. of our Thesry and all receevers and collectors of our rents revenues customs and casualities qtever present or for the time being to readily answer and pay the forsd pension att ye terms above mentioned to ye sd Mr James quheranent these prnts shall be to all qcerned a sufficient warrant Given at our Court att Kensingtonune ye twelf Janry 1699 and of our reigne the tent year. ${ }^{3}$

Eleven years later, in a Warrant of Queen Anne dated I7th March I7Io, Sutherland had created for him a Regius Professorship of Botany which was to lead to rival schools of botany in the city.

Thus did Sutherland rise to prominence not only by assiduously serving Balfour and Sibbald during the formative years of the Trinity Hospital Garden but also by his own industry and talent as a botanist and teacher and gradually the Garden began to enjoy the highest esteem, both in Britain and in Europe. Its progress however was not without incident. Sutherland had a hard struggle to fulfil the obligations in his Trinity lease to maintain the property on the site as well as to raise sufficient funds for the upkeep of the Garden. In 1684 he suffered the loss of all his personal possessions when Sibbald's house and 'the chamber of Mr James Sutherland .... were burned to the very vaults' in a fire caused by the negligence of their neighbour, Lady Forsyth, whose maid left a coal fire

I Wm. Maitland, the history of edinburgh, (I 753 ).

2 Wm. Nicolson (I655-I727), author of S CO TTISH HISTORICAL LIBRARY, (I702).

3 PRIVY SEAL REGISTER, vol. 5, f. I26, I2th January I699. 
unattended. After a law suit the Privy Council awarded him damages of 500 merks in restitution.

A much greater disaster was to overtake Sutherland and the Garden in the spring of 1689 when, during the siege of Edinburgh Castle, Sir John Lanier and other leaders, for strategic purposes, took it upon themselves to drain the Nor' Loch. The dam at the east end of the Loch was broken to allow the water to pass into the channel which ran through the centre of the Trinity Hospital Garden. The volume of water being far greater than the channel, which was designed only for overflow, could take, the entire site of the Garden was inundated for several days. As the flooding subsided the ground was found to be covered by inches of mud and rubbish from the city drains and all but the hardiest plants, so patiently collected by Balfour, Sibbald and Sutherland, were practically obliterated. The clearing of the ground alone took Sutherland and his men an entire season. This was only the first stage of restitution, however, for the tender and rare plants which had been lost had to be replaced-at the expense of time and money. Equally disastrous from Sutherland's point of view was the fact that he was left without livelihood; having nothing to demonstrate to his pupils, their fees, his only regular source of personal income, were abruptly cut off.

The general financial situation was a constant source of irritation and worry to him. Far too much of his time seems to have been spent on preparing petitions to the Town Council and to the Privy Council for money to meet every day running costs. That he set about the virtual recreation of the Garden in such circumstances speaks much for his dedication to botany and gardening.

By 1693 the Privy Council were convinced of the justice of his claims for financial assistance for in a decree of 7 th February they accepted, for once unequivocally, if tardily, the need to recompense him for the Nor' Loch flooding. Accordingly he was voted fifty pounds sterling annually, twenty-five pounds as a personal salary and twenty-five for the expenses of the Garden, the disbursement of the latter under the supervision of a committee; these sums were to be paid from the Council's income from fines. The decree however was not without its sting for it ended 'And the saide Lords Doe hereby Recommend to the Committee as formerly to speak with the sd. Mr James Sutherland anent his Medalls'. This was more than a hint that Sutherland was spending too much time on his antiquarian pursuits. Even so the reprimand seems singularly in- 
appropriate for someone who had so successfully overcome the major catastrophe in the history of the Garden; only six months later a Town Council decree is referring to the reconstructed Garden as 'for numbers and rareness of plants .... inferior to few gardens in Europe'.

There is no question that Sutherland's reputation as an antiquary, and as a numismatist particularly, fell little short of his excellence as a botanist. At this stage however he was still expansionist and dominated botanical teaching in the city. To his students, those of the physicians, and the apothecaries, he now added the apprentices of the College of Surgeons, recently granted new privileges under a Warrant of William III. By an Act of the College of I Ith June I695 he undertook 'the instruction of Apprentices, servants, and such others as have the libertie and priviledge of insight in the shops [they] immediately at entrie to their service to pay a Guinea or twenty three shillings sterling'. He further undertook to wait upon the Masters 'at a solemn publick herbarizing in the fields four severall times every year'. He thus consolidated his influence with both medical factions, a measure perhaps of his importance. It is worth noting that this Act of 1695 is the first document to use the term Botanic Garden to describe the Physic Garden at Trinity Hospital, perhaps, as we have seen, to avoid confusion with the College's Physic Garden.

Sutherland's career was crowned by his appointment, four years later, as King's Botanist and by his freedom from personal financial difficulty through the successful prosecution of his teaching and the stipends he received for the Keeperships of the three Gardens. The situation of his assistants, however, did not greatly improve and the regular maintenance of the Gardens was no more guaranteed than ever it had been. In the College Garden, for example, the gardener, William Cleghorn, had to appeal to the Council on account of the condition of his numerous family and the inadequacy of his salary. The Council responded on 5th April 1699 with a grant of ten Rex dollars and later, in December I 70r, his salary was increased from eight pounds Scots yearly to ten pounds sterling. A Town Council minute of 5th May 1699 reveals the disrepair into which the boundaries of the Botanic Garden had fallen: 'the wester wall .... of the way Leading from the Newport to the Mutriceahill being so low that the sheep coming to the town that way.... eat the herbs and plants of the garden'. By this time Sutherland was no longer concerned with the practical supervision of the Garden for Bailie 
Hamilton and his committee recommend in the same report that a fit person be appointed to oversee the Garden and nominate James Paterson as being so qualified.

In I706, at the age of sixty-eight, Sutherland resigned as Master of the Botanic and College Gardens and his Chair of Botany in the University and 'resolved to live more retirdly and to quite the said professione and applie himself to the studie of meddalls'. Although on the grounds of age alone his retirement at this stage in his career would not appear to be in any way extraordinary, it was, in fact, precipitated by another reprimand. Some months earlier the Town Council had reduced his College Garden salary from twenty pounds to five pounds and had threatened that the remaining five pounds, together with the ten pounds he received from the Chamberlain for overseeing the Botanic Garden, would also be withheld if he did not give better attendance at both. This is not to say that he frequently absented himself from the city. In his younger days he had travelled widely in Scotland-'his late Personal View and Examination of the Shores and Mountains of Anandale, Niddisdale etc. have amply discovered to him the Riches of his own Country', writes Nicolson ${ }^{1}$ - but the only known occasion on which he was given leave was for a journey to London in 1687 'anent his affaires in relation to the improvement of his art'. This present action was against sheer neglect of his responsibilities and arose from a complaint to the Council by the Deacon of Surgeons that Sutherland was 'very much defective in his duty as to the teaching chyrurgeon Apprentices in the Science of bottony which was a considerable part of his employment'. For good measure the Principal and Treasurer of the College complained at the same time that the yard of the College was altogether neglected and 'noeways keeped in order as it ought to be'.

Only Grant in OLD AND NEW EDINBURGH, records the dignified response that for many years Sutherland had 'taught the science of herbs to students of medicine for small fees, receiving no other encouragement than a salary of twenty pounds from the city, which did not suffice to pay rent and servants' wages, to say nothing of the cost of new plants so difficult to procure in those non-travelling times'. Sutherland's own reply to the charges laid against him is not reported but there can be little doubt that in the light of the general neglect of the College and Physic Gardens the

I See p.I4. 
charges were justified. Neither can there be doubt but that, in expressing his desire to spend more time on his coins, he was turning to his now predominant interest.

His chastisement by the city authorities left the King's will unaffected and Sutherland remained Regius Keeper and King's Botanist of the Royal Garden at Holyrood. To replace him in the Town and College posts, on 8th May I706, Charles Preston was elected by a Council decree.

Sutherland's Royal patronage continued into the reign of Queen Anne who corroborated William IIr's appointments with a Warrant of her own dated I7th March i7io. However, on the death of Queen Anne in I7I4, his posts became void, and the following year he was succeeded in them by William Arthur. Thus from I706 until I7I4 Sutherland no longer held a monopoly in the field of botanical education in Edinburgh and for those eight years two rival schools of botany existed-that of the Royal Garden and that of the University.

What can only be fragments of Sutherland's correspondence, but the only known examples, are preserved in the British Museum. Of the fourteen extant letters, nine are addressed to James Petiver, apothecary and antiquary, three to Dr Richard Richardson of Yorkshire, and one each to the distinguished botanist Sir Hans Sloane and Ralph Thoresby the Leeds historian. All are dated between 25th March I700 and I9th September I702. Two further letters, from R. Wodrow to Sutherland, are preserved in Edinburgh University Library; both are dated within the same period and both refer only to coins. In spite of their limited range in relation to Sutherland's career which spanned thirty years the Petiver letters particularly throw light on how a collection of plants was gradually brought together. They also reveal the dual interests of Sutherland, for, in some, the talk of coins clearly predominates.

If his botanical career did not quite terminate when he resigned from the Town and College posts it can hardly have been influential thereafter in spite of his continuing tenure of the Royal appointments. He leaves the scene in almost as much obscurity as he entered it. Beyond a passing reference to him in a letter from Sir Robert Sibbald to Sir Hans Sloane dated 2sth February I714-'Mr Sutherland is yet alive but keeps his chamber as doe I, we come but seldome abroade'-no light can be thrown on his last years.

He died on 25th June I7I9, aged over eighty, and was buried on the 26th in Greyfriars Kirkyard 'close to the south wast corner of 
Mortons Staine'. Whatever the vagaries of his career, he was, as J. M. Cowan truly says, ${ }^{\mathrm{I}}$ a man of great activity and interest who well deserves to be remembered. Happily he always will be remembered by the group of South African shrubs named in his honour-Sutherlandia.

I NOTES ROY. BOT. GARD. EDINB., XIX (1933), P.I3-62. 


\section{CHAPTER THREE}

\section{William Arthur}

IT IS NOT SURPRISING THAT ON THE ACCESSION OF KING George I, the office of King's Botanist, with care of the Royal Physic Garden at Holyrood-a Household appointment and therefore held only during pleasure-which Sutherland had filled during the two preceding reigns, was not conferred upon him-the septuagenarian numismatist that now essentially he was. Instead, the appointment was given to Dr William Arthur whose Warrant of Appointment, although sealed on Ioth May I715, was dated 28th July I7I5.

Dr. Arthur, Botanist, 28 July 1715.

George etc. fforasmuchas Wee Considering yt. it is necessary that the physick Garden at the palace of Holyrood house be keept in good order and for that effect that all due Encouragement be given to a person skilled in Botany who may have the Inspection of the said Garden and may be oyrwise usefall to the lieges by Instructing them in the usefall Science of Botany And we being well Informed of the good Qualifications of $\mathrm{Mr} \mathrm{Wm}$. Arthur, Dr of Medicine as to his fitness for the office of Botanist and of his good affection to us and our Government Therefor witt ye us with the advice and Consent of the Lord Chiefe barron and remanent Barrons of our Exchequer in Scotland to have made Constituted and appointed Like as Wee by those presents Make Constitute and appoint the Said $\mathrm{Mr}$ Wm. Arthur During our pleasure only to be our botanist within that part of our Said Kingdom And Wee Give and grant unto him the oversight care and inspection of our said physick garden to the effect he may keep the Same in good Order With power to him to Sett up a profession of Botanic and materia medica and to Teach the Same and to have and Enjoy the haille fees Casualities priveleges and Immunities of the said office as fully and freely as the Same was possessed by Mr. James Sutherland heretofore And for the said Mr Wm. Arthur his further encouragement Wee have given and Granted and hereby Give and grant to him During the Space forsaid the yearly 
Sallary of fifty pounds Sterling monie to Commence from the 25 day of March I7IS years and So furth thereafter to Continue During our pleasure as said is Given at our Court at St. James's and under our privy Seale of Scotland the Ioth day of May I7IS in the first year of our reigne. Per Signaturam Signo manu Q. D. M. Regis Suprascript. Manibusque Barrons. Scaccarii Scoticae subscript.

If Arthur was 'skilled in Botany' there is absolutely no information about him or his work in any botanical history. In fact his name had been excluded from the published records of the Royal Botanic Garden until it was rediscovered by Isaac Bayley Balfour whose account of Arthur in the TRANSACTIONS AND PROCEEDINGS OF THE BOTANICAL SOCIETY OF EDINBURGH for IgIS furnishes the material for this story. For an explanation of Arthur's appointment, therefore, it is necessary to look not at his professional attainments but rather at his family connections.

$\mathrm{He}$ was born in I680 into a well-known Fife family, the fourth son of Patrick Arthur of Ballone, formerly a surgeon apothecary at Wemyss but by then settled at Elie, and Commissioner of Supply for Fife. In due course, choosing medicine as a career, William journeyed to Leiden, at that time dominated in medicine by the great Boerhaave, from which he graduated MD on I2th March 1707. He appears to have returned to Elie since he is known to have practised medicine there, and, although academically qualified, would have been precluded from establishing himself as a doctor within the City of Edinburgh until formally licensed by the College of Physicians, an event which did not take place until Ist June I7I4. Nevertheless he had entry into the highest society in Edinburgh, for on 2 Ist February I7Io he married Barbara, widow of Sir John Lawson of Cairnsmuir, and sister of Baron of Exchequer John Clerk, second baronet of Penicuik. His practice no doubt benefited from this marriage-Clerk, for instance, became one of his patients. And certain it is that having no knowledge of plants beyond that required of any physician of his time his preferment as Regius Keeper and Regius Professor was due to the political influence to which his marriage gave him access.

By the time of his appointment it would seem that he was socially secure and well on the way to a successful career. Thus his involvement in the Jacobite plot of I7Is which was to bring about his ruin, particularly in the light of the patronage of figures prominent in the Government such as Clerk and the Lord Justice-Clerk, Lord Ormiston, is all the more surprising and can only be explained by 
assuming that his Jacobite sympathies were much more deep-rooted than any of his friends had cause to suspect. The story of the plot is told in Scott's TALES OF a GRANDFATHER.

James, Lord Drummond, son of that unfortunate Earl of Perth, who, having served James vII as Chancellor of Scotland, had shared the exile of his still more unfortunate master, had been rewarded with the barren title of Duke of Perth, was at this time in Edinburgh; and by means of one $\mathrm{Mr}$ Arthur, who had been formerly an ensign in the Scots Guards, and quartered in the Castle, had formed a plan of surprising that inaccessible fortress, which resembled an exploit of Thomas Randolph, or the Black Lord James of Douglas, rather than a feat of modern war. This Ensign Arthur found means of seducing, by money and promises, a sergeant named Ainslie, and two privates, who engaged that when it was their duty to watch on the walls which rise from the precipice looking northward, near the Sally-port, they would be prepared to pull up from the bottom certain rope ladders prepared for the purpose, and furnished with iron grapplings to make them fast to the battlements. By means of these, it was concluded that a select party of Jacobites might easily scale the walls, and make themselves masters of the place. By a beacon placed on a particular part of the Castle, three rounds of artillery, and a succession of fires made from hill to hill through Fife and Angus shires, the signal of success was to be communicated to the Earl of Mar, who was to hasten forward with such forces as he had collected, and take possession of the capital city and chief strength of Scotland.

There was no difficulty in finding agents in this perilous and important enterprise. Fifty Highlanders, picked men, were summond up from Lord Drummond's estates in Perthshire, and fifty more were selected among the Jacobites of the metropolis. These last were disbanded officers, writers' clerks and apprentices, and other youths of a class considerably above the mere vulgar. Drummond, otherwise called MacGregor, of Bahaldie, a Highland gentleman of great courage, was named to command the enterprise. If successful, this achievement must have given the Earl of Mar and his forces the command of the greater part of Scotland, and afforded them a safe and ready means of communication with the English malecontents, the want of which was afterwards so severely felt. He would also have obtained a large supply of money, arms, and ammunition deposited in the fortress, all of which were most needful for his enterprise. And the apathy of LieutenantColonel Stewart, then deputy-governor of the castle, was so great that, in spite of numerous blunders on the part of the conspirators, and an absolute revelation on the subject made to Government, the surprise had very nearly taken place.

The younger conspirators who were to go on this forlorn hope, had not discretion in proportion to their courage. Eighteen of them, on the night appointed, were engaged drinking in a tippling-house, and were so careless in their communications, that the hostess was able to tell some person who inquired what the meeting was about, that it consisted of young gentlemen who were in the act of having their hair powdered, in order to go to the attack of the castle. At last the full secret was entrusted to a woman. Arthur, 
their guide, had communicated the plot to his brother, ${ }^{\mathrm{I}}$ a medical man, and engaged him in the enterprise. But when the time for executing it drew nigh, the doctor's extreme melancholy was observed by his wife, who, like a second Belvidera or Portia, suffered him not to rest until she extorted the secret from him, which she communicated in an anonymous letter to Sir Adam Cockburn of Ormiston, then Lord Justice-Clerk, who instantly dispatched the intelligence to the castle. The news arrived so critically that it was with difficulty the messenger obtained entrance; and even then the deputy-governor, disbelieving the intelligence, or secretly well affected to the cause of the Pretender, contented himself with directing the rounds and patrols to be made with peculiar care, and retired to rest.

In the meantime, the Jacobite storming party had rendezvoused at the churchyard of the West Kirk, and proceeded to post themselves beneath the castle wall. They had a part of their rope ladders in readiness, but the artificer, one Charles Forbes, a merchant in Edinburgh, who ought to have been there with the remainder, which had been made under his direction, was nowhere to be seen. Nothing could be done during his absence; but, actuated by their impatience, the party scrambled up the rock, and stationed themselves beneath the wall, at the point where their accomplice kept sentry. Here they found him ready to perform his stipulated part of the bargain, by pulling up the ladder of ropes which was designed to give them admittance. He exhorted them, however, to be speedy, telling them he was to be relieved by the patrol at twelve o'clock, and if the affair were not completed before that hour, that he could give no further assistance. The time was fast flying, when Bahaldie, the commander of the storming party, persuaded the sentinel to pull up the grapnel, and make it fast to the battlements, that it might appear whether or not they had length of ladder sufficient to make the attempt. But it proved, as indeed they had expected, more than a fathom too short. At half-past eleven o'clock the steps of the patrol, who had been sent their rounds earlier than usual, owing to the message of the Lord JusticeClerk, were heard approaching, on which the sentinel exclaimed, with an oath, "Here come the rounds I have been telling you of this half-hour; you have ruined both yourself and me; I can serve you no longer'. With that he threw down the grappling-iron and ladders, and in the hope of covering his own guilt, fired his musket, and cried 'Enemy!' Every man was then compelled to shift for himself, the patrol firing on them from the wall. Twelve soldiers of the burgher guard, who had been directed by the Lord Justice-Clerk to make the round of the castle on the outside, took prisoners three youths, who insisted that they were found there by mere accident, and an old man, Captain MacLean, an officer of James vil, who was much bruised by a fall from the rocks. The rest of the party escaped along the north bank of the North Loch, through the fields called Barefoord's Parks, on which the New Town of Edinburgh now stands. In their retreat they met their tardy engineer, Charles Forbes, loaded with the ladders which were so much wanted a quarter of an hour before. Had it not been for his want of punctuality, the information and precautions of the Lord Justice-

I The William Arthur of our Story. 
Clerk would have been insufficient for the safety of the place. It does not appear that any of the conspirators were punished, nor would it have been easy to obtain proof of their guilt. The treacherous sergeant was hanged by sentence of a court-martial, and the deputy-governor (whose name of Stewart might perhaps aggravate the suspicion that attached to him) was deprived of his office, and imprisoned for some time.

This story, which appeared with varying detail elscwhere, ${ }^{\mathrm{I}}$ was later fully corroborated by William Arthur himself.

William Arthur did not linger in the city but made his way south on horseback eventually reaching Coldstream where he stayed long enough to be in communication with his wife. 'She sent me a most Lamentable Letter telling me that she had been visited by my Lord Orm[istoun] Her Brother Baron Clerk and Sir Jo[hn] Ingles ${ }^{2}$ airly that morning, who finding her Ignorance too plainly by her inundable [sic] astonishment desir'd her to invite me home in their name with abundance of fine promises that I cannot think of yet without the utmost scorn'.3 The three gentlemen were close relations of his. He had married Baron Clerk's sister; Baron Clerk had married Sir John Inglis's sister; Sir John Inglis had married a daughter of Lord Ormiston, to whom he was also stepson; Clerk was Inglis's brother-in-law and the husband of Ormiston's stepdaughter. And it was to these, Arthur confessed, that he owed his appointment as Professor of Botany and Materia Medica and Keeper of the Royal Garden.

How long he remained in the Borders or what finally influenced him to abandon his wife and career and exile himself is not recorded; he is known only to have reached Rome. His last act of allegiance to the Stuart cause was to write an account of the Castle plot in I7I6 in a long letter to the Earl of Mar, leader of the rebellion of I7IS on behalf of the Pretender, entrusting it on his deathbed to a

I MEMOIRS OF THE LIFE OF SIR JOHN CLERK OF PENICUIK, BARONET. Edited by John M. Gray for the Scot. Hist. Soc., (1892); John, Master of Sinclair, MEM OIRS OF THE INSURRECTION IN SCOTLAND IN I7I5; Patten, HISTORY OF THE REBELLION IN THE YEAR I 7 I 5 , 3rd ed., p.I35; Rae, HISTORY OF THE LATE REBELLION, I7I8; MahOn, HISTORY OF ENGLAND FROM THE PEACE OF UTRECHT TO THE PEACE OF AIX-LA-CHAPelle, I, (I836), p.220; Hogg, the JACOBIte RELICS OF SCOTIAND, (I82I), p.230; Grant, OLD AND NEW EDINBURGH, I, (1880), p.67.

${ }^{2} \mathrm{Sir}$ John Inglis of Cramond, son-in-law of Lord Ormiston and brother-in-law of Baron Clerk.

${ }^{3}$ Arthur's letter to the Earl of Mar, in 1716. 
Dr Roger Kenyon who wrote to Mar from Rome on I7th October I716:

Enclosed is the legacy of an honest man, and a very faithful subject, $\mathrm{Mr}$ Arthur, who after escaping a thousand dangers in the King's cause, met his death where he came from safety by eating a few figs which threw him into a dysentry. The day before he died, he ordered these papers to be delivered me, and desired me to send them you with some excuse for their coming in a form so little fit for your perusal. Had God allowed him a longer time, that would have been amended, and you would have received with these an account of what passed at Preston in his observation. You will receive them just as they were delivered me, and I have only to add, that, several being named who may yet be in danger or unwilling to be generally known, he assured himself you would take care, that living or dying, he might be hurtful to nobody. I had known him only since my coming here, but, as far as I could judge, besides a true zeal in the King's cause, an excellent heart, and no talents wanting to have made him most useful in his station, he seemed to be a great lover of truth, not only so as not to alter it, but even to speak it, where it might not be over grateful. This may make his relation even in the lesser circumstances of it, of more regard, and, since it came to my hands, it has been seen by nobody. We had permission to bury him by the sepulchre of Cestius, a piece of antiquity well known here and within the walls, which is esteemed a favour to us sort of people, and was procured by means of Cardinal Gualterio.

Such was the opinion of Dr Roger Kenyon. The Earl of Mar's opinion and appreciation of Arthur's services are cynically shown in this letter to Captain Harry Straton of 15 th November I7I6:

A countryman of yours, a very pretty young man, is lately dead at Rome, Dr Arthur, and his brother Tom, who is at Francis' quarters (the Firth of Forth) has fallen so ill on it, that 'tis feared he'll die too. The Doctor at his death, I hear, declared he was a Presbyterian, but a loyal one, as he called it, which he thought was not at all inconsistent. You know what was his kind of loyalty. Pray are many of your Presbyterians of his opinion?

So ended the career of one who was as unsuccessful a conspirator as he was unrenowned as a botanist, and who, but for Bayley Balfour's assiduous historical research, might have disappeared for ever from the roll of Regius Keepers of the Royal Botanic Garden. 


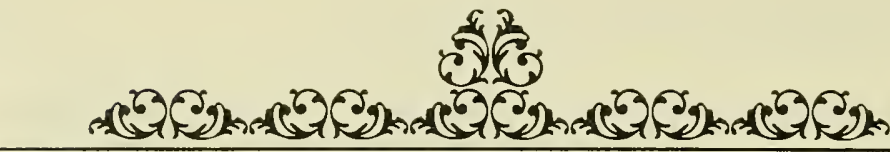

CHAPTER FOUR

\section{Charles and George Preston}

WHEN SUTHERLAND WAS DEPRIVED OF HIS ROYAL APPOINTments apparently there was no obvious successor to him. It was very different in 1706 when he renounced his teaching post in the University and surrendered the care of the Botanic Garden, for Edinburgh's medical circle held, in Charles Preston, one with a ready-made reputation as a botanist and thus, from this point of view, very worthy to take up the posts Sutherland had vacated.

Little is known of Preston's early life ${ }^{\mathrm{I}}$. He was born on I2th July I660, the second son of Robert Preston by his second wife, Margaret Bothwell, and was brought up on the family estate of Gorton which lay in the Esk valley not far from Hawthornden Castle, some six miles south of Edinburgh between Roslin and Lasswade. The ancient stronghold of Craigmillar Castle was the home of his ancestors, and in I454, one of them, William Prestoune of Gortoune, granted a charter for the construction of the Preston Aisle in the High Kirk of St Giles in return for the hereditary right of his lineal descendants to be the bearers of the venerated relic, the arm-bone of the Saint, in all public processions of the College of St Giles, a right which was ended in the riots of 1558 . His branch of the family eventually took the name of Prestons of Valleyfield but the estate reverted to its older name of Gorton in the lifetime of Robert Preston. It is interesting to note that the Governor of Edinburgh Castle, at the time of the I7Is rebellion which saw the downfall of William Arthur, was George Preston, the second son of George Preston-sixth of Valleyfield.

With such a family background and a father who was knighted and elected a Senator of the Royal College of Justice, Charles

For a detailed account of the Prestons, see Cowan in NOTES ROY. BOT. GARD. EDINB. XIX (1935), p.63-134. 
evidently enjoyed a comfortable childhood. He developed into a cultured young man with wide scientific interests and, to judge from his letters, he was an omnivorous reader. From contemporary evidence we know that he took lessons in botany from James Sutherland and although he may have attended the University of Edinburgh he appears never to have graduated. Medicine early attracted him and, since Edinburgh as yet did not have a Medical School, Charles studied in Europe, visiting France, Holland and Flanders, finally taking his doctorate in medicine at Rheims on I4th July I696. It was in the course of these travels that he came in contact with many of the leading scientists of his day-men like Herman of Leiden and Tournefort in Paris. On his way home to Scotland he spent some time in London where he met with many of the outstanding members of the Royal Society, including Sir Hans Sloane, the Society's President, with whom he corresponded for the next fifteen years. The correspondence was somewhat one-sided: 'I wrote frequently to you sometimes by common post at other times by the Secretary's office, but have never received answer.... I am mightily concerned that I cannot hear from you' he wrote to Hans Sloane on 23rd May I699, in a letter which, like many of his others, is preserved in the Sloane manuscripts in the British Museum. He corresponded also with such distinguished botanists of the day as James Petiver, John Ray and Leonard Plukenet, all of whom appear to have held him in high esteem. Robert Brown also must have been aware of his virtues otherwise he would not have commemorated his name in the genus Prestonia.

Charles Preston was back again by the summer of 1697 in Edinburgh and some time after March I698 he entered Aberdeen University where he graduated on 2 Ist June I699. On returning to Edinburgh a surprise was in store for him; he was summoned before the College of Physicians to account for his actions in having practised medicine on his return from the continent in 1697 without holding a licence from the College whose monopoly was so jealously guarded:

Edgr., 30th June 1699.-The Qlk day Mr Charles Prestone indweller in Edgr a pretended practitioner of physick ther, was decerned at the instance of Alexr Ross pror ffiscall to pay to Dr James fforrest treasurer of the colledge ffyve pounds Sterling for his first moneths unwarrentable practising of physick within the ceitie of Edgr and liberties thereof wtout license of the colledge in respect he Compeared formerly befor the Colledge and refused to depone upon the lybell, and was thereafter ceited to this day and place 
and also formerly ceited personally apprehended by the Colledge officer to have compeared and deponed upon the lybell and he not compearing was holden as confest yrupon and decreit pronunced and ordained to be extracted and put in executione against him. ${ }^{1}$

In spite of the fact that he appears not to have paid the fine, Charles Preston was elected a socius of the College on Ist December I704 and was in favour enough the following year to be appointed its 'Secretary and Library Kepper . . . . for the ensewing year'. It is unlikely that he took his medical practice very seriously. His interests, especially his botanical ones, were too wide for this and he was still living outside the city, at Gorton, where he was cultivating a small botanic garden. Moreover he found the disputes among the members of the medical profession distasteful to him. This he makes clear in a letter to Sir Hans Sloane in I702: 'The number of physicians are so multiplied here and their divisions so great that I have but little encouragement to stay among them.... I am truly weary of this country there is so much jangling amongst the physicians qch renders the employment the more contemptible'. Nevertheless he had many friends in the profession including both Sibbald, of whom he had a high opinion, and Sibbald's bitter rival Pitcairne, Edinburgh's most popular physician.

By 1705 Preston had sufficiently moderated his opinion of his medical colleagues to apply to the Royal College of Surgeons for the post of instructor in botany to their apprentices, a petition granted readily enough in a minute of the College dated 8th November I705:

The Deacons being [convened] anent the petition [given] in be Charles Preston doctor of Medicine Making mention that for many years past he had applyed himself to the study of Botany both at home and abroad and while he was in [foreign] England and Holland was at great pains and charge in procureing of [seeds] plants and goods from the said Countryes and Sending them to Scotland for purposes .... of the phisicall garden at Edinburgh .... And now Mr James Sutherland professor of Botany [being] not able to attend the Garden and Scholle as formerly And that the said Doctor Charles Preston being willing .... to prescribe and promote in his power the said Science of Botany and to [teach] ye apprentices and Servants etc yrin after a new and .... method never taught in Brittaine before And yrfore craved the Calling would be pleased .... Therefore the Deacon Masters and Brethren of the said [Incorporation] have GRANTED and by their presents GRANTS .... of the Said petition Nemine Contradicente And have Recalled

I Royal College of Physicians, Edinburgh; Minutes of Meeting of 3oth June 1699. 
and hereby recalls the former Act made in favour of the said Mr James Sutherland and ordaines that all ye apprentices and Servants and others who shall be taught and instructed by the said Doctor Charles Prestone in the Said Science of Botany shall at the subject .... pay a guinea or twenty three shillings and eight pence Sterling to the Thessaur of the Said Incorporation who shall .... ffor the which cause the Said Doctor Charles Prestone shall be obleidged and by these presents bind and obleige him to own and acknowledge all masters and Brethern of the Said [Incorporation] .... as his patrons and to attend them on any afternoon in the Garden when they [think fit] and to wait on them at a Solemn publick Herbalizing . . . in the Country ....

From this appointment to the occupancy of the Chair of Botany in the Town's College was a short step and on 8th May I706 the Town Council minuted his appointment as Professor and Keeper of the College Garden on the same terms, a salary of fifteen pounds, which had been enjoyed by Sutherland; 'ten pound starline money yearly by Thomas Fisher the good touns chamberlaine and his successors in Office and five pound starline yearly by James Dewar present colledge theasurer and his successors in Office .... Contrast this with the fifty pounds sterling salary for the sinecure of Arthur's Keepership at Holyrood!

Once installed in his posts, Preston's career was uneventful. He performed his teaching duties adequately enough and to the satisfaction of his joint masters, the Surgeons and the Town Council, but he had less interest in the development of the Gardens in his care than had his predecessor. The exchange of plants which he began soon after his return from the continent in I697, initially to stock his garden at Gorton and later to improve the collections of the Botanic Garden, was not maintained to any extent after his appointment as Intendant in spite of its being a condition written into the minute 'to carrie on the Said professione of Bottany cultivate the Said gairdines respective and to keep correspondence for procureing plants and seeds from forreigne countries'. Nor is there any evidence to suggest that the gradual disrepair of the Trinity site was due to anything other than Preston's lack of interest. Unlike Sutherland apparently he had little aptitude for the practical side of gardening.

The Surgeons made great demands on his time-apprentices had to attend at 4 am to be back in their masters' shops by 7 a m-and there was his liability to attend to any of them whenever they chose to appear. Presumably to augment his modest income he also had to undertake public instruction as an advertisement in the 
EDINBURGH COURANT of I6th May I707 shows: 'Doctor Preston teaches his lessons of botany in the Physic Garden [ie the Botanic Garden] at Edinburgh, the months of May, June, July and August, I707. Therefore, all gentlemen and others, who are desirous to learn the said science of botany, may repair to the said garden, where attendance will be given.'

Preston's only published work appeared before his College appointment and consists of three short medical papers in the PHILOSOPHICAL TRANSACTIONS OF THE ROYAL SOCIETY OF LONDON of 1694 and 1698 . The only other literary remains are the letters addressed to Sir Hans Sloane between I697 and I7II. Covering as they do the whole of his working life they supply almost all the tangible evidence of his botanical and more general scientific interests. Unfortunately they tell next to nothing about the development of the Botanic Garden; and they tell nothing at all about the man himself. His social life is rarely mentioned. However, it is known that he was unmarried and after his licensing by the College of Physicians and becoming eligible to undertake medical practice it is probable that he left Gorton to reside in the city where he lived alone, unpretentiously and perhaps frugally, for on his death in December I7II, at the age of fifty-one, his estate amounted to no more than half a year's salary, ninety pound Scots. His possessions were equally meagre, "his whole books and pamphlets valued by Alex. Henderson bookseller in Edinburgh to the sum of f90 IIs. Scots money. Item a press and two trunks very old worth f3 Scots, Item of money that was lying beside the defunct at his death $£ 48$ money foresaid.'I As the value of the pound Scots was equal to twenty pence sterling his total wealth was, therefore, less than twenty pounds. It is fair to assume that he was no business-man and true to say that, in spite of his early promise, probably he was one of the least successful administrators to be associated with the Botanic Garden.

If little is known of Charles Preston still less has been recorded of the early life of his brother George who succeeded him as Professor of Botany in the Town's College and Intendant of the Botanic Garden at Trinity Hospital. Not even his date of birth is established although it appears from an obituary notice ${ }^{2}$ that he

I Edinburgh Commissariat of Register of Testaments, Will of Charles Preston 23rd January I7I2.

${ }^{2}$ EDINBURGH CALEDONIAN MERCURY of 2 oth February 1749. 
was born in 1665 or 1666 and therefore was five or six years younger than Charles: 'Thursday last died suddenly at Gorton, Mr. George Preston, Surgeon-Major of His Majesty's Forces in North Britain, aged 84 , a gentleman eminent in his profession, and very useful to all ranks of persons in that country.' The records of the Royal College of Surgeons suggest that he was trained abroad. However, as he was apprenticed to Alexander Hay, HM Apothecary in Edinburgh, on 14th May I684, at which time he was only eighteen, or at most nineteen years old, his early training can scarcely have been extensive.

As soon as he had completed the seven years for which he would be bound, he joined, as Surgeon, the newly raised Cunningham's Dragoons, later the 7 th Hussars, formed in Scotland in September 1690 as six troops of horse mainly to undertake policing duties in the Highlands. It is difficult to ascertain how tied he was to his regiment, the appointment of Surgeon being something less than a formal commission, but early in I693 the Dragoons were ordered to England to prepare for embarkation for Flanders for which they were eventually to leave in May 1694. However a number of the regimental officers, Preston among them, remained in Scotland to further a recruiting campaign and early in 1694 Preston had disappeared from their roll and would seem to have severed his military career, at least for the time being. I In common with his brother, George Preston's biographical record is slight, but it is clear that his military duties had in no way conflicted with his other professional interests and throughout he was able to carry on a successful business as an apothecary even after his appointment as Professor of Botany.

Around 1697 he married Marion, daughter of John Wauchope of Hill, to whom only a daughter, Isabella, who pre-deceased him, was born. 'Macer' Wauchope, so called because he carried the mace of the Court of Session, died soon afterwards and, having been a Burgess of the City of Edinburgh, he enabled Preston 'by right of his wife' to take his late father-in-law's place, his name being entered in the Roll as Burgess and Guild Brother on 4th May I698.

An advertisement in the EDINBURGH GAZETTE on 9th October I70I illustrates the manner in which the business of an apothecary was carried on in Edinburgh at that time:

I On 16th February 1703 he was appointed Surgeon-Major to the Forces in Scotland, an office he retained for life. 
George Preston, apothecary and druggist, is newly arrived with a large parcel of all sorts of drugs newly come from the Indies; as also, all sorts of spices, sugars, tea, coffee, chacolet, etc., and are to be sold at his shop, in Smith's New Land, on the north side of the High Street, foregainst the head of Blackfriar's Wynd, Edinburgh. Printed lists, with their prices, are to be seen at his shop.

Quite clearly the shopkeeper bad to travel far for his supplies and it is likely that George Preston made regular journeys to London to buy direct from vessels as they docked. He was certainly in London in 1702 , with an introduction from his brother to Sir Hans Sloane, but, from one of the two letters written by him known to exist, both to Petiver, he did not, on this occasion at least, meet Sloane.

Whilst establishing himself as an apothecary he was also busy establishing his reputation as a botanist possibly with a view to succeeding his brother. Whether or not this had been his intention, on the death of Charles in December I7II, he lost no time in applying to the College of Surgeons to confer on him the recognition his brother had enjoyed as instructor; to this the Deacon Masters agreed in an Act in his favour dated 3 Ist December I 7 Ir. He was to continue to teach all the apprentices who had already paid fees and

.... to oun and acknowledge all the Masters and Brethren .... and to attend them or any of $\mathrm{ym}$ in the Garden when they incline yrto and to wait on $y m$ at a Solemn public herbalizing Tyst in the country or where the Calling shall think fitt and that four terms in the year . . . at such times as shall be appointed and to teach and instruct all their prentices Servants and others who shall pay to him . . . a Guinea . . . . the true, best and most easy methods of knowing, classing and distinguishing the Trees, shrubs and plants as he shall think fitt, and furder to cause plant what is wanting in the dispensatory in the Garden ....

Two days later the Town Council met to consider his application for the Chair of Botany in the Town's College and 'Master' of the Botanic Garden and on 4th January I7I2 the minutes record his appointment at the same salary paid to his brother. Out of this sum. he had to pay a ground rent of $£ 40$ Scots to Trinity Hospital for the lease of the Garden, but, to compensate, he had a free house and, of course, his fees from the surgeon apprentices besides whatever he could make from the sale of drugs in the Garden. It is interesting to speculate on what might have happened had the Town Council failed to appoint him, coinmitted as he now was to holding classes 
in the Garden for the benefit of the Surgeons. There might have been yet another rival school of botany.

Of Preston's position and of the state of the Garden there is an interesting comment in Alex. Bower's THE HISTORY OF THE UNIVERSITY OF EDINBURGH (I8I7):

The remuneration which Mr Preston received from the patrons must be acknowledged to have been very small. It is to be regretted that not the least vestige remains by which it can be ascertained what numbers attended the Physic Garden. It was . . . . open to the public during the course of the whole day throughout the season, in the time of his predecessor; and it is likely $\mathrm{Mr}$ Preston continued this practice. The emoluments he could derive from the medical plants which he reared in the garden must have been very trifling; and, considering his paltry salary, the only inducement he could have to continue giving instructions in botany, could arise from those who attended him. The local situation of the garden at Trinity Hospital was exceedingly unfavourable for the purpose to which it was applied. It had little or no exposure to the rays of the sun; the soil very swampy; and the plants exceedingly liable to be injured, from its not being properly inclosed. When $\mathrm{Mr}$ Preston was made professor, it appears, from the representation which he gave in to the Town-Council, that the walls were in the most ruinous state, so as to afford no protection. He succeeded however in getting them repaired; but the disadvantages of the situation still formed a great objection; and this was the cause of erecting the greenhouse in the college [i.e. Botanic] garden ....

Charles Preston indeed had left the Garden in a state of some disrepair if his brother's representations to the Town Council on roth September I7I2 are not exaggerated. In these first nine months George Preston had

.... been at Considerable Charges in Laying two new Syvers for draining of the Ground that was much ruined with underwater And in Laying a new ground above these sivers and other parts of the Garden for the better Improving of the plants . . . he would be at yet more Considerable Charges in bringing of new plants out of forreign Countries and was of Intention to build a greenhouse which was most necessary for preserving of forreign and tender plants and trees [but] his present sallary was so very mean that he Could not proceed in so great undertaking .... I

The Council acceded to the request for assistance and agreed to add ten pounds to his salary on condition that he built the greenhouse, but they also took the opportunity to mention, for the first

I EDINBURGH TOWN COUNCIL RECORDS, vol. 4O, f.5I I, IOth September 1712. 
time since Sutherland's appointment, his obligation to keep the College Garden in good order.

By 27th February I7I3 he had submitted to the Town Council firm plans for the erection of his greenhouse

... . to consist of about threty four feet in LENGTH and sixteen foots in breadth and forme the north side wall thereof nine foots within the Colledge kirk yeard . . . and that at the sight of the Dean of Gild and his Councell and further the Councell allowed to the sd Mr George Preston the use of the stove or cahall presently standing in the toun Clark's chamber to be put up in the said Green house upon his report and obleisment to return the same when called for .....

On 18th March the Council authorized the Treasurer to put in hand the repair of the parts of the Botanic Garden wall that had become ruinous, and the construction of the greenhouse was completed during the summer.

Thus was the first glasshouse in the history of the Garden erected. Preston was proud and on 24 th October 1713 was able to write to Petiver: '. . . . if you have any exotick or rare seeds to send me some of them it will be a greate obligation to me for I am more capable to preserve them then my predecessors were by reason I have built a Greenhouse and provyded all other materials for preserving and cultivating plants ....'

In his first year of office (1712) Preston issued a catalogue of the plants in the Botanic Garden under the title CATALOGUS OMNIUM PLANTARUM QUASIN SEMINARIO MEDICINAE DICATO TRANSTULIT GEORGIUS PRESTONUS, now known only in its second edition published in I7I6. After Sutherland's CATALOGUE of 1683 it forms one of the earliest lists of the plants cultivated in Scotland. Preston claimed to the College of Surgeons that he had introduced five hundred new species into the Garden, some of which were new to Scotland. However the actual number of plants mentioned by Preston and not recorded by Sutherland, is small. Both Juglans regia the common walnut, and Laburnum vulgare (now $L$. anagyroides) the common laburnum, are among the new records and their entry in Preston's catalogue possibly is the first printed record of their cultivation in Scotland. Preston no doubt was responsible for the introduction to Scotland of the Cork Oak of Southern Europe and North Africa, Quercus suber, which was growing in the Duchess of Beaufort's garden in 1699-the earliest

${ }^{I}$ EDINBURGH TOWN COUNCIL RECORDS, vol. 4I, f.32, 27th February I7I3. 
record for Britain. The few others not in Sutherland's list were mostly medicinal herbs which of course would be important enough to the author as an apothecary.

Thus, unquestionably Georgc Preston was more interested in the Garden than had been his brother. Unquestionably also he was more businesslike than his brother. Not for him to be at the beck and call of the apprentices at any time of the day whenever they cared to visit him. He fixed his own times at which he would give instruction. The morning session during the summer tcaching tcrm was postponcd from $4 \mathrm{am}$ to $5 \mathrm{am}$ and finished at $7 \mathrm{am}$ and in the afternoons Preston was present on three days in the week.

Like Sutherland he found the financial situation of the Gardens in his charge his greatest worry. Not only was the Town Council unwilling to consider the capital outlays he felt to be necessary but he was soon in difficulties over the fees due to him by his pupils, the apprentices of the Surgeons. The matter developed into a considerable dispute over which the Surgeons were required to give judgement and ordained that failure by masters to hand over the prescribed guinea would result in the Clerk to the College withholding the apprentices' indentures. To add to his troubles, in the new lease of the Botanic Garden that he had to negotiate with the Treasurer of Trinity Hospital on 6th May 1719, he incurred an annual rent of $f_{5} 5$ sterling, more than twicc his previous liability. He was granted a renewal for fifteen years

.... to Digg Delve Manure and Plant the sd Gardine at pleasure durcing the time forsaid Always reserveing Libertie free ish and Entrie to any one of the members of the sd Hospitall for the time being to walk at their pleasure either in the South or North Gardinc . . . . and obleidges him and his forsaid upon his own proper charges and Expences to Maintain Uphold and keep in Good Order and Condition the Flower Plotts Walks and Hedgeings of the said Gardine . ....

Preston's activities as teacher, intendant and apothecary possibly were too diverse for him to give reasonable attention to any of them. After his initial enthusiasm he scems to have lost interest in the Gardens and to have become somewhat disheartened. Dr William Sherard, who endowed the Chair of Botany at Oxford, complains to a correspondent in 1720 'I will spcedily write to $\mathrm{Mr}$ Preston, but do not find him so good as he promises, having never received one specimen from him.' In November 1724 the

I EDINBURGH TOWN COUNCIL RECORDS, vol. 46, f.I58, 6th May I7I9. 
Town Council revoked Preston's right to the neglected College Garden, which from this date ceases to have any connection with the Botanic Garden:

THE SAME DAY [IIth November] anent a Memoriall given in by Messieurs Rutherford, St. Clare, Plummer and Innes shewing that these gentlemen having purchased a house for a chymical Elaboratory adjoining to the College Garden formerly let to $\mathrm{Mr}$ George Preston and finding that the Garden neglected by Mr Preston had for some years lain in disorder Desired of the Honourable the Toun Councill that they might be allowed the use of that ground for the better carrying on their design of furnishing the Apothecary Shops with chymical medicines and instructing the students of medicine in that part of the Science.... I

At this time the Botanic Garden also seems to have fallen on evil days and this, partly at any rate, may have been the fault of the gardener Robert Wood who lived in the Garden and was then probably the only gardener on the staff. Preston certainly blamed Wood as is clear from a letter from Philip Miller, gardener to the Company of Apothecaries at Chelsea, to Dr Richardson; writing on I9th August 1727, the year before Wood's death, Miller says: 'I have lately received a letter from Mr Preston at Edinburgh with great complaints of their loss in the Physic Garden, and he attributes it to the illmanagement of Mr Wood, who I hear but a slight character of'; then Miller significantly adds 'but I am in hopes that Dr Alton [Alston] who is King's Professor of Botany at Edinburgh, will be the best correspondent there; he seems to be a man of learning, and has good skill in distinguishing Plants, and a great share of modesty.'

Thus while the reputation of the Regius Professor, Arthur's successor Charles Alston, was standing high, that of Preston was gradually on the decline. Even so Preston carried on, increasingly ineffectually, until $\mathrm{I} 738$. His resignation may have been accepted with relief by the Town Council which no doubt realised that it would be but logical to fill the University Chair with the very able man who was King's Botanist in charge of the Royal Garden, and Regius Professor.

Preston was to live for another eleven years, retiring to Gorton where he died suddenly on I6th February I749 at the age of eightyfour years, his merits, like those of his brother, cast into the shade by the lethargy which overtook them both.

${ }^{Y}$ EDINBURGH TOWN COUNCIL RECORDS, vol. 50, f.374, I I th November 1724 . 


\section{CHAPTER FIVE}

\section{Charles Alston}

SO FAR, THE STORY OF THE BOTANIC GARDEN AND ITS associated College Garden in Edinburgh, from the initial enthusiasm of Andrew Balfour, Robert Sibbald and James Sutherland, to the ultimate indifference shown by the Prestons, is a sorry one, reflecting the parsimony of successive Town Councils as much as the personal failings of the physicians and botanists concerned. But now a change was at hand, a change which was to bring remarkable progress and a sudden upsurge in the fortunes of the Gardens. And almost all the credit for this is due to the lofty example shown by Charles Alston, Arthur's successor at the Royal Garden at Holyrood, the King's Garden, who not only sustained botanical teaching at Holyrood when it was in decline in the hands of the College professors, but so consolidated it that, within a comparatively short time, Edinburgh's school was able to enjoy a reputation second only in Europe to that at Leiden.

Traditionally, the Alstons came from England with the founders of the Dukedom of Hamilton, in the time of Robert the Bruce, and the Alstons of Thinacre-Milne were the progenitors of all the families of that name in the West of Scotland. The father of Charles Alston was Dr Thomas Alston of Thinacre-Milne and Eddlewood, Lanarkshire, the first in the line to have studied medicine. Charles, the fourth son, was born in $1683^{\mathrm{I}}$ and in I 700 entered the University

I A short autobiography, in manuscript, written towards the end of his life, and discovered in the Edinburgh University Library's Alston Manuscripts by Sir Isaac Bayley Balfour, differs in two important respects from accepted chronology. It states (I) that he was the third son born on 24 th October 1685 , the only specific date cited in any biographical record, and (2) that he was at Leiden only from June 1718 to August 1719. Balfour publishes these dates in his brief account of Alston in Oliver's MAKERS OF BRITISH BOTANY (I9I3). If all Alston's contemporaries are correct in unanimously noting that he died at the age of 77 , he must have been born in I683. Recent evidence from extant family records in the possession of a descendant, Dr J. M. Alston, suggests however that the manuscript is the more correct version. 
of Glasgow. Unfortunately the death of his father three years later cut short his academic career and left the family in some distress. The interest of the Duchess of Hamilton in the family's plight led her to attempt to make some provision for their support by having Charles indentured to James Anderson, Writer to the Signet in Edinburgh, with a view to his ultimate appointment to a place in her service. His heart was not in the law, however; "Anatomy and the [apothecary] shops were more agreeable to him than style books, or the Parliament House.'I However, on matters of law he spent three fruitless years in Edinburgh before entering into the Duchess's service as her 'principal servant'.

However dismal an appearance this change of state (from a Writer to a Servant, of one so far advanced in years) seemed to have, yet it pleased the Divine Providence, to make it the means of putting him into more favourable circumstances, than he could reasonably have hoped for, for as he had aboundance of spare time, he ply'd close the Mathematicks, and whatever else he thought of use to a student of Medicine, particularly Botany; and was encouraged in it by his Kind Mistress. ${ }^{2}$

When Arthur fled to Rome in I715 the Duchess saw her opportunity to further the cause of Alston. Using her immense political influence she decided to acquire for him a commission from George I appointing him King's Botanist, Professor of Botany and Materia Medica, and Overseer of the Royal Garden. As the Dukes of Hamilton were hereditary Keepers of the Palace of Holyroodhouse she had little difficulty in fulfilling her aims and the warrant was sealed on 3oth June I7I6, a mere four months before she died. Moreover, as the commission was one held only at the Sovereign's pleasure and as Her Grace expected her successors to show little concern for the fate of her own favourites, she made over to Alston a bond tying her executors to pay him $f_{500}$ in the event of his being deprived of the salary of fifty pounds attached to his appointment.

Assisted in this way, Alston was now in complete freedom to devote himself to his real interests and to the development of the much neglected Royal Garden. However, no matter how profound his self-acquired knowledge and his capacity to impart it may have been, he was, at this stage in his career, nothing more than a gifted amateur, unqualified in the eyes of the profession for teaching. This

I Alston's MS autobiography.

2 ibid. 
situation had to be corrected and towards this end he departed almost at once for Leiden, ${ }^{\mathrm{I}}$ mecca of the Scottish physicians, to become, at the mature age of thirty-three, a student of Boerhaave.

On his return to Edinburgh he commenced his course of lectures at the King's Garden in June I720 and in the following November conducted his first 'college' in materia medica. In the meantime he also took the earliest opportunity to establish his position among his medical colleagues by graduating as a Doctor of Medicine at Glasgow on 2nd December I7I9 and by applying for admission to the Royal College of Physicians of which he was elected a Fellow on Ist August I72I. His reputation appears to have developed rapidly and the College appointed him its Secretary on and December I725, an office he was to hold for the remarkably long period of twenty-one years. On the accession of George II in I 727 he was confirmed in his post, on this occasion on merit alone, so that the fears of his late patroness, fortunately for botanical science, never were to be realised.

By this time Alston was approaching middle age. Even so, in some ways he was only on the threshold of his career. To a teacher as conscientious as he, the quality of instruction provided to the members of the medical profession by George Preston was a matter of grave concern. Moreover, from his eminent position in the College he could not fail to observe the gradual deterioration of the reputation of his own science. He was witnessing, too, the destruction, by neglect, of what ought to have been a major Botanic Garden had the high intentions of Balfour and Sibbald not been eroded by blundering mismanagement. Above all else, however, Alston was determined to share in the restoration of the medical lectures in Edinburgh to a position in which they might compete with the great continental schools, Leiden in particular, an end to which the professors of the recently instituted medical faculty were working, and one they had often discussed with Alston.

His plans in this direction hinged on Preston's vacation of the College Professorship, an event which did not take place until 1738 . However, when it did come about there was no need for him to solicit the post; there could be no candidature more suitable than his and he was received as a member of the University on 3 Ist March 1738. No salary was attached to his new post and so for a time he was still dependent on his royal stipend. However, in 1746

I See footnote on p. 37 . 
'as the Doctor has now, upwards of twenty-five years, been employed in that station [professor of botany] and, as such, has deservedly acquired a very great character', the Town Council, as Patrons of the Chair, allowed him five hundred marks annually, a gesture significant in its public acknowledgement of Alston's record.

As soon as his appointment as College Professor was confirmed Alston was able to collaborate with his colleagues in an integrated lecture course which exhaustively covered all the branches of medicine. Those involved were all deeply influenced by Boerhaave, and, apart from Alston, two of them had been pupils of the great Leiden master. These were Andrew Plummer, Professor of Chemistry, and Alexander Monro, Professor of Anatomy and perhaps Alston's most intimate friend, whose course included human and comparative anatomy. The others concerned were Andrew Sinclair, Professor of the Theory of Physick, who used as his text the Institutiones medicae of Boerhaave, and John Rutherford, Professor of the Practice of Physick, who discoursed on Boerhaave's APHORISMI DE COGNOSCENDIS ET CURANDIS MORBIS. And now there was Alston himself, in his fifty-fifth year, lecturing on materia medica in the winter and teaching botany in the Botanic Garden in the summer. All the 'colleges' of medicine commenced about the middle of October and ended in April. Botany was the exception, being held only in the months of May, June and July.

Thus Alston had gathered into his hands all the appointments held by James Sutherland and set the pattern, that was to be followed without a break for the next two centuries, of combining the commission of King's Botanist in Scotland with the Chair of Botany in the University of Edinburgh. Thereafter the Royal Garden at Holyrood diminishes in importance as a botanic garden-although never to be neglected with Alston as Keeper-and as soon as the Botanic Garden at Trinity Hospital was restored to some semblance of order Alston transferred his botanical teaching there.

There is a curious absence of record about the Trinity Garden's progress, but, with the inspiration of Leiden never far from Alston's mind, it is fairly certain that it was not long before he had made the Garden as reputable as the Medical School. The author of the anonymous manuscript ${ }^{1}$ quoted earlier which contains the biographies of a number of botanists and physicians writes of 
Alston's persevering and laborious exertions: 'The soil of his garden was not very tractable, or its situation very commodious; but he nevertheless improved it with diligence, and was greatly assisted and countenanced by his friends both at home and abroad in enriching it with the seeds of exotics, or of such natives of the British Isles, as had not then found a place in it.'

The foremost person to whom he had recourse for assistance in increasing the Garden's resources was, not unnaturally, Boerhaave, from whom he had been receiving seeds for many years, certainly since 1720 , for in April of that year, Boerhaave wrote to Alston:

The agreeable letter which you have sent me demands seeds, but does not specify which kinds you are chiefly anxious to obtain. Ignorant of your wishes, I send a few. I wish they may give satisfaction. I have now published another index, select from it what seeds you desire, and give me a catalogue of them; I shall then take care to have these seeds collected during the summer. You are acquainted with our garden, bestow on it supplies of such seeds as you shall be possessed of, whether natives of America, or from other quarters you shall have obtained them. I, for my part, shall take care, that you may have no cause to repent of this reciprocity of good offices; but shall send all that I shall be able of such seeds as you desiderate. Farewell, and have recourse to me as to your friend.

Boerhaave apart, Alston received the seeds of exotic plants from many of his correspondents. One of the more interesting of the latter was clearly Patrick Blair, the anatomist and botanist, who when in practice in Dundee in I706 had distinguished himself in a somewhat extraordinary manner by taking advantage of the death of an elephant in a travelling show to dissect the animal and 'although he was obliged to hasten it on account of the heat of the weather he employed considerable accuracy in its prosecution.' Blair was not one of Alston's regular correspondents and in 1724 was confused by the latter's status, for in October of that year he wrotefrom Boston, Lincolnshire:'Excuse my ignorance in the following query, whether you are Botanick Professor in the College and have the inspection of theirs and the physicians' Garden ${ }^{\mathrm{I}}$ or whether you have succeeded to Mr George Preston in the Physick Garden.'

A more frequent correspondent was another Scot exiled in London, Dr John Fothergill, in honour of whom Linnaeus named

I Another early Edinburgh garden that had no connection with the personalia in this story. It was attached to the Physicians Hall in Fountain Close, lying between that building and the Cowgate. It was regarded as a pleasure ground not only by the Fellows of the College but by many of the gentry living in the neighbourhood. 
the genus Fothergilla. Fothergill supplied Alston with a constant stream of information on matters of materia medica which came his way. In his letters he regularly expresses his obligation to his former teachers in Edinburgh and on one occasion expresses his disappointment with Linnaeus. In a letter written in London in December I 740 he says: 'I did not take it well that Linnaeus had made no mention of the Physick Garden at Edinburgh in his FUNDAMENTA BOTANICA tho' he had taken notice of some that deserved less.' He went so far as to send a copy of the second edition of Preston's catalogus to Gronovius at Leiden, a close friend of Linnaeus and one of the first converts to the latter's 'sexual system' of classification. 'I dare say he'll be glad of it, and if there be a Second Edition of his [Linnaeus's] book justice will be done.'

The Botanic Garden was, of course, still without regular endowment but, when once a stipend was attached to the College Professorship, Alston's professional income was more by far than that enjoyed by any of his predecessors and probably he was able to provide the gardening staff required without the great strain on his resources suffered, for example, by James Sutherland.

In 1740 , at the age of fifty-seven, ${ }^{\mathrm{I}}$ and for the assistance of his pupils, Alston published his first work-INDEX PLANTARUM PRAECIPUE OFFICINALIUM, QUAE IN HORTO MEDICO EDINBURGENSI; it was an index to the plants demonstrated to his pupils in the Botanic Garden. Although he contributed three medical papers to EDINBURGH MEDICAL ESSAYS, the most important of them on opium, another twelve years were to elapse before his next major work, INDEX MEDICAMENTORUM SIMPLICIUM TRIPLEX-lists of official names and a classification of them according to their virtues. In this same year of 1752 he published his first DISSERTATION ON QUICK-LIME AND LIMEWATER, but the botanical work for which he was to gain most renown in his lifetime was that which followed in I753, TIROCINIUM BOTANICUM EDINBURGENSE. This introduction to botany contains a re-issue of the INDEX PLANTARUM of I740 together with the FUNDAMENTA BOTANICA of Linnaeus, as well as a third critical part which represents Alston's first public attempt to explode Linnaeus's 'sexual system' of classification which grouped plants according to the number of stamens and pistils in the flower. His criticism was directed against the system

I See footnote on p.37. 
not as a method of arranging plants by readily recognised characters, but from the standpoint of his denial of the existence of sex in plants. He went to a great deal of trouble to try to prove that stamens were not necessary for the development of fertile seeds and gave examples of seed production when the application of pollen had not been possible. It would almost seem that Alston was fully aware of the condition which was to puzzle botanists for generations to come-until, in fact, the explanation of the phenomenon now known as apogamy was supplied.

So strongly did Alston feel about this matter that he translated the third part of the TIROCINIUM into English and published it, the following year, in the first volume of a new Edinburgh journal, ESSAYS AND OBSERVATIONS, PHYSICAL AND LITERARY. The publication of this translation occasioned a long letter from Philip Miller of Chelsea: 'I wish you had not published your paper .... as it is repugnant to a doctrine so well established especially as those experiments you mention have been found otherwise in almost every place where they have been tried', wrote Miller in February I755. Without a trace of acrimony Alston replied a little over a year later: 'But if they [his experiments] have not been found always otherwise my argument is good .... I hope I will be allowed also to depend on my own as on other people's eyes, especially since they were not made to confirm an opinion but on the contrary oblige me to alter one which I had long entertained.'

Miller's objections by no means formed the only resistance Alston met in attempting to refute Linnaeus's ideas. But Alston was not to change, and Pulteney, in his SKetches of THE PROGRESS OF BOTANY, ', gives the reason why.

Could the doctrine of the sexes of plants have been easily shaken, the learning and abilities of Alston were sufficient to have affected his purpose. But as it was not at that time supported by hypothesis alone, so it has since gained additional strength, by new experiments, and found inductions, resulting from them. Nurtured from his early years in the systems of Tournefort, Ray and Boerhaave, to the first of which he had even given improvement, it is not strange, that at an advanced age, Dr Alston rejected a system of so much novelty, as that of Linnaeus presented. We do not willingly unlearn at sixty, what has been cherished from our earliest youth.

In 1754 there was published a small octavo volume entitled A DISSERTATION ON BOTANY, the title page carrying the

I Vol. 2 (I790), p.I2. 
sentence 'Translated from the Latin by a Physician'. The translator's preface speaks of Alston's 'great natural abilities, learning, universal knowledge, sagacity, accuracy, candour, caution, solid judgement, indefatigable industry, inventive investigation, ardent love and steady pursuit of truth, and sacred regard for the public emolument and utility, joined to that tempering sweetness of disposition .... The DISSERTATION however was not an original Latin work. The 'translator' was Alston himself, who may be forgiven his little conceit if it helped to restore his reputation and correct the impression, widely held, that in the TIROCINIUM he had committed a serious error of judgement.

The DISSERTATION is interesting from another point of view, for it tells which botanical matters occupied his thoughts and those which did not. It is clear, for instance, that anatomical matters were of some interest to him. At the same time it is surprising and certainly disappointing to realise that, although he was a close correspondent of Stephen Hales and obviously must have known of this pioneer plant physiologist's experimental work, he seems not to have appreciated its importance. Unquestionably Alston's interests were strongly biased to materia medica-and his favourite subject of quick-lime and water.

Until a few years before he died Alston was still occupied with his experiments on quick-lime, continually investigating clinical cases in which lime-water had proved efficacious. A second edition of his DISSERTATION on the subject appeared in I754, followed by a second and a third DISSERTATION in 1755 and 1757 . This latter was to be his last publication for he was now seventy-four years of age. He lived for another three years and died on 22nd November 1760. Many years later Robert Brown commemorated his name in the genus Alstonia.

Ten years after his death another loyal and fitting tribute was paid to him by John Hope-probably Alston's most distinguished pupil-who edited for publication Alston's own manuscript materia medica notes that he had been preparing for publication at the time of his death. No slave to his late mentor's doctrines, especially in the matter of the Linnaean controversy, the respect in which Hope held Alston is clear from the introduction to the two materia medica volumes. 'As a Professor, communicative and knowing no greater pleasure than to form the minds of his pupils in such a manner as to render them able in their profession and useful members of society .... But the lectures themselves will best delineate his abilities as 
a teacher; and the pains he had taken to distinguish truth from falsehood before he proposed his sentiments to his audience.'

From these two volumes, as well as from the fact that Alston's teaching was strongly biased to materia medica, it is quite clear that botany in Edinburgh at this time, as in many places elsewhere, was still nothing more than the hand-maid of medicine. 


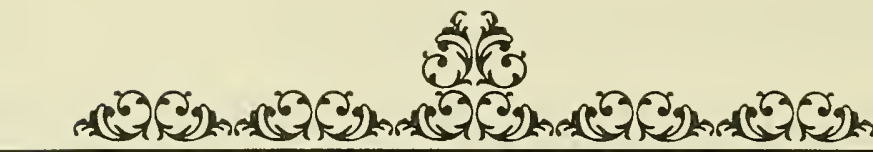

\section{Interlude to}

\section{Parts One and Two}

IN THE I 7 TH CENTURY THE BOTANIC GARDEN IN EDINBURGH was not the only such Garden in Britain. Almost half a century earlier, in I62I, the first Physic Garden had been founded and endowed, at Oxford, by the Earl of Danby, for the study of drug plants or 'simples'. It was laid out on the site of the old Jews' burying ground opposite Magdalen College from whom the Garden is still leased by the University. The magnificent gateway, the Danby Gate, designed by Inigo Jones, was erected in 1632 . However, not until I642 was the Garden ready for occupation and then Danby tried to secure the services of Charles I's gardener, John Tradescant, as Curator or Keeper of the Garden. Failing in this, he appointed an old Brunswick soldier, Jacob Bobart, who began to build up his collection of plants, mainly medicinal, to the effect that in 1648 he was able to publish a catalogue which listed the names of some 600 native plants and some 1,200 from abroad.

In I669 the first Chair of Botany in Britain was established at Oxford and was filled by Robert Morison who 'translated himself to the Physic Garden where he read in the middle of it (with a table before him) on herbs and plants for five weeks space, not without considerable Auditory'. I Bobart worked closely with Morison, as indeed did Bobart's son, Jacob, who succeeded his father in I680 and died in I7I9. Some years later, Dr William Sherard, a distinguished patron of botanical science who had given plants to the Oxford Garden, books to the Library and $f_{5} 50$ towards the enlargement of the Conservatory, endowed a Chair of Botany and Dr Johann Jakob Dillenius who was born at Darmstadt and who had accompanied Sherard to England in I72I was appointed the first Sherardian Professor of Botany in 1728 greatly

I S. H. Vines and G. C. Druce, THe Morisonian herbarium, XXIv (I9I4). 
adding to the interest of the collection in the Garden during the nineteen years of his office. Unfortunately his successor, Humphrey Sibthorp, who held the Chair from 1747-83, appears to have taken little interest in the Garden and not for many more years was real progress to be made at the Oxford Garden.

Of much greater influence, certainly in the I8th century, was the Chelsea Physic Garden and its great gardener Philip Miller, who, especially in England, largely dominated horticulture and gardening. The Chelsea Garden had been founded as the Garden of the Society of Apothecaries in London in 1673. In I712 Dr (afterwards Sir Hans) Sloane had purchased the freehold of the Manor of Chelsea, including the Garden, and in 1722 had conveyed the Garden by deed to the Society of Apothecaries 'to the end that the said garden might at all times thereafter be continued as a Physick Garden, and for the better encouraging and enabling the said Society to support the charge thereof, for the manifestation of the power, wisdom and glory of God in the works of the creation, and that their apprentices and others might better distinguish good and useful plants from those that bore resemblance to them, and yet were hurtful and other the like good purposes.'I

Shortly after Sloane's deed of conveyance Miller was appointed Head Gardener at Chelsea and in 1724 published his first work, the two-volume THE GARDENER'S AND FLORIST'S DICTIONARY, Or a COMPLETE SYSTEM OF HORTICULTURE, which he dedicated to the Apothecaries' Company. Four years later he demonstrated his skill as a cultivator by communicating to the Royal Society, which had been founded in 1662, a paper on 'A method of Raising some Exotic Seeds which have been judged almost impossible to be raised in England'. His horticultural skill at this time was badly needed for plants from overseas were coming into the country in large numbers, hothouses for their cultivation were multiplying, and many such plants were grown and flowered at Chelsea for the first time in cultivation; plants from the Cape, Siberia, North America, and the West Indies, to the extent that the Chelsea Garden was said to exhibit the treasures of both the Indies. Miller determined to impart the knowledge he had acquired of these new plants to others, and in I73I published his monumental work THE GARDENERS DICTIONARY of which the great Swedish botanist Linnaeus said that it was not simply a dictionary of gardening but

I P. E. F., Perrédès, London botantc Gardens, (I906), p.57. 
of botany as well, and which earned for him, overseas, the title of 'Prince of Gardeners'. From the time of its publication until Miller's death in I77I eight editions of the work were to be published, with a further eight editions during the first thirty years of the Igth century. Miller lived to see the number of plant species cultivated in Britain increase fivefold. In I73 I about a thousand were in cultivation; when he died in I77I there were rather more than five thousand.

As early as I7Ir, Trinity College, Dublin, also possessed a Physic Garden and Dr Henry Nicholson, the first lecturer in botany, published a pamphlet on it in I7I2-METHODUS PLANTARUM IN HORTO MEDICO COLLEGII DUBLINENSIS JAmJAm Dispondenarum. The Garden at Kew, which was destined to develop into the greatest Botanic Garden in the world, was not established until 1759 when Princess Augusta initiated a botanic garden of some nine acres in the region of Kew House, a garden which occupied a position about 50 yards south-west of the present Kew Orangery. William Aiton, who had been one of Philip Miller's assistants at Chelsea, was made the first Curator, and the first unofficial Director was the Earl of Bute, a botanist of some distinction. The second Director, also unofficial, was far more distinguished, Joseph Banks. Aiton was to serve as Curator for thirty-four years publishing in 1789 his three-volume HORTUS KEWENSIS Or a CATALOGUE OF THE PLANTS CULTIVATED IN THE ROYAL BOTANIC GARDENS AT KEW which not only listed the 5,500 species which were in cultivation but classified them according to the system of Linnaeus, gave their country of origin, the date of their introduction and by whom they had been introduced.

Not until I76I was there to be a Botanic Garden in Cambridge although John Gerard, herbalist, botanist and surgeon, had proposed one, to Lord Burghley, in I588. And for the thirty years previous to I76I botany in Cambridge was in poor shape. Sir J. E. Smith, the first President of the Linnean Society, well described it when he said: 'Botany slept from I734 till $\mathrm{r} 76 \mathrm{I}$, when Walker raised it from a deep slumber. The Professor had neither salary nor students.' The Professor was John Martyn who practised medicine in Chelsea and journeyed to Cambridge, until $\mathrm{I734}$, to deliver his lectures. After $\mathbf{1} 734$ the lectures were discontinued for there was neither a botanic garden nor students and no one cared. However, as he was on the point of retiring, in $176 \mathrm{r}$, Richard 
PLATE I

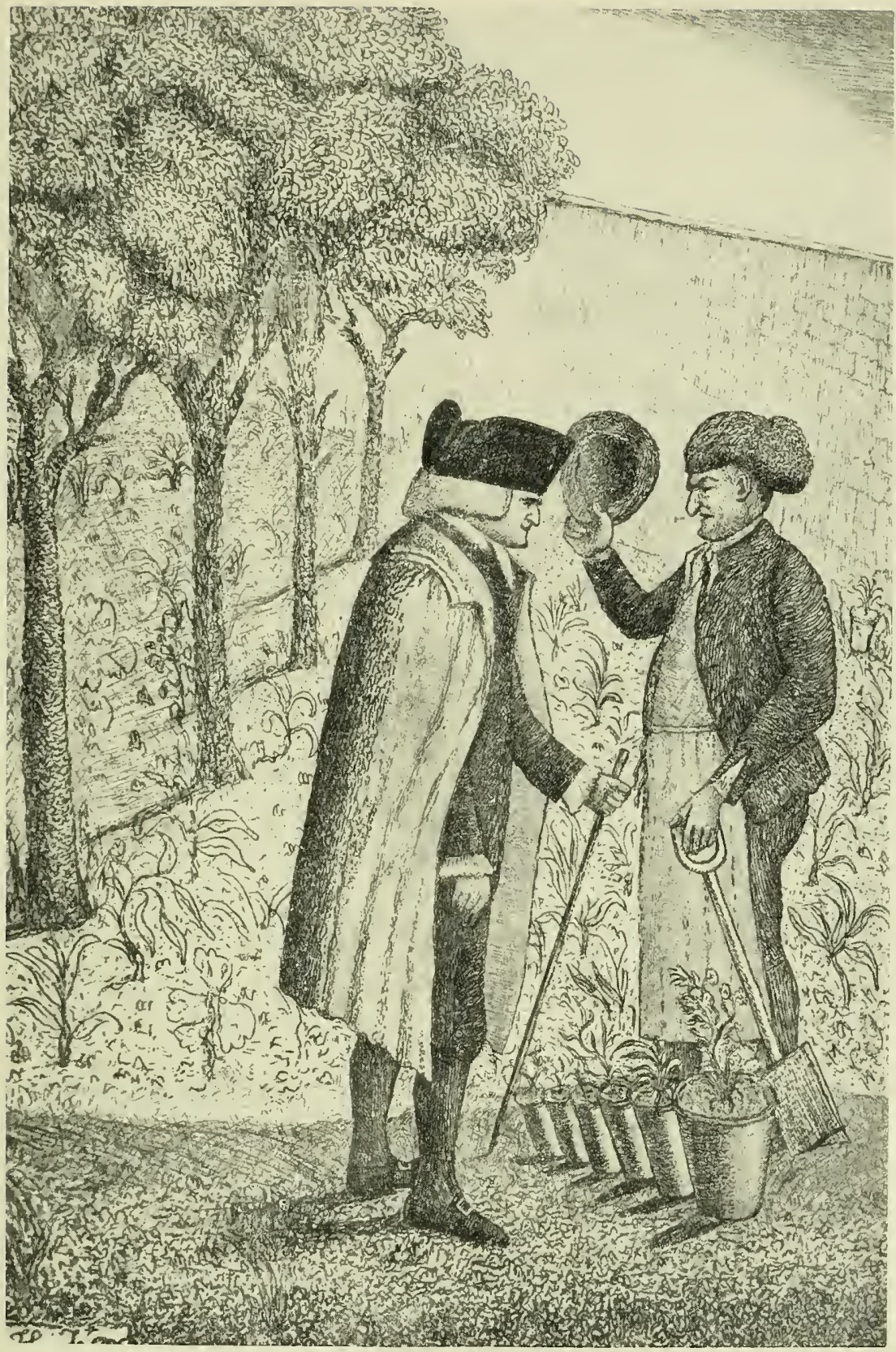

John Hope (1725-I 786), Regius Keeper of the Garden and King's Botanist I76I-1 786 
The old Trinity Hospital, the Physic Garden is in the foreground

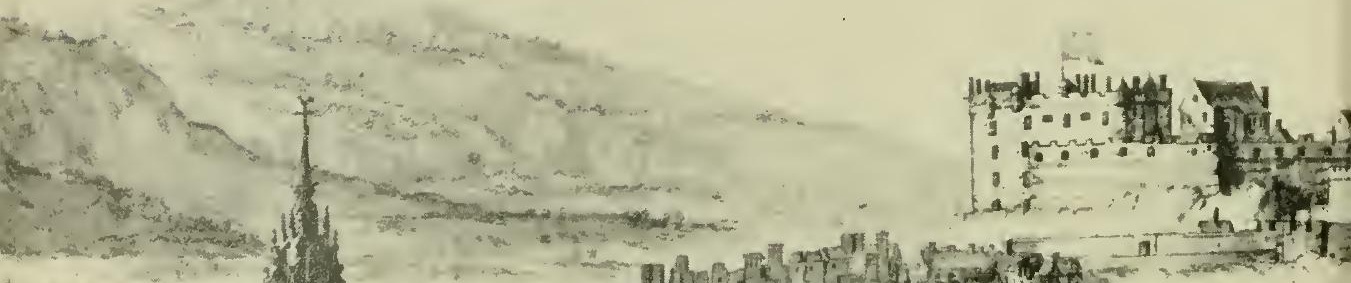

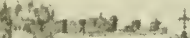

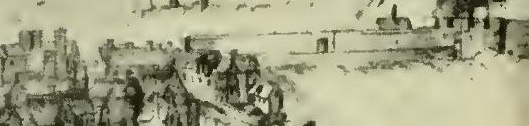

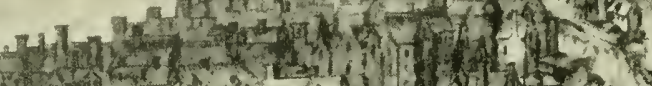

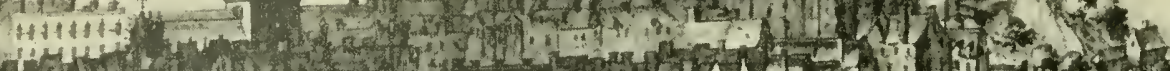

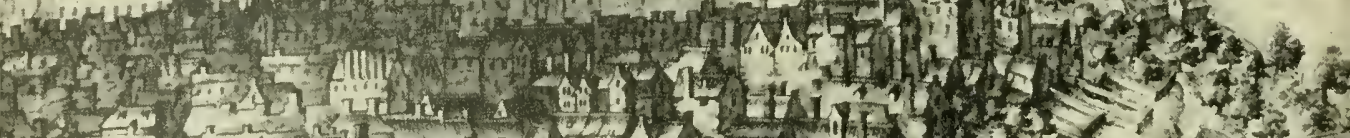

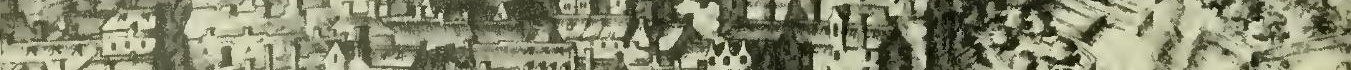
(1)

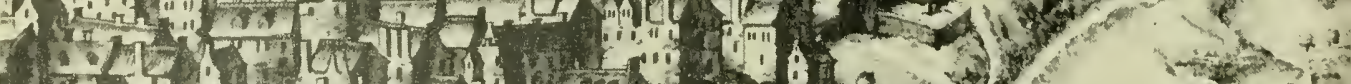

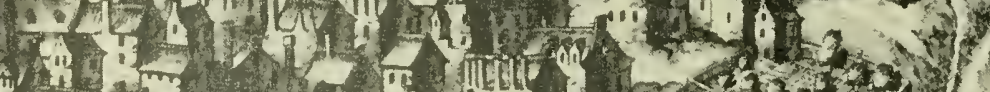

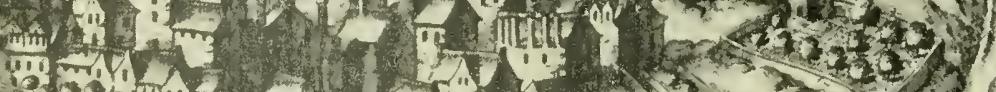

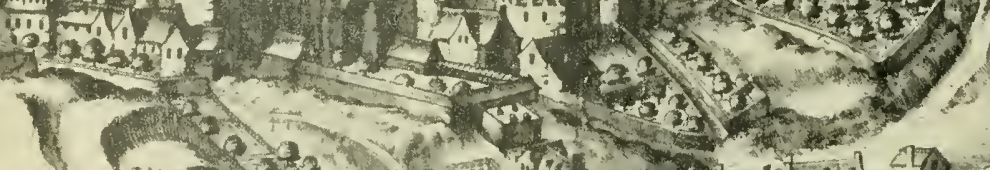

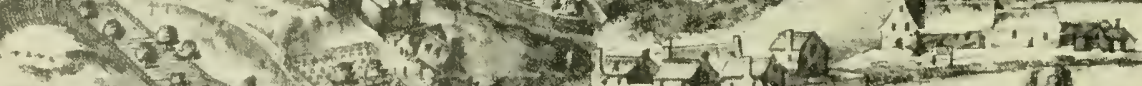

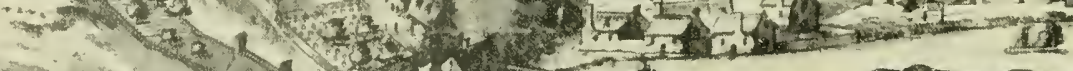

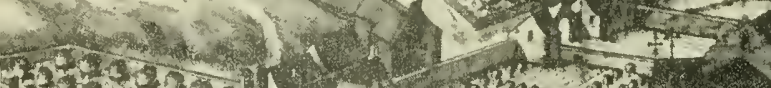

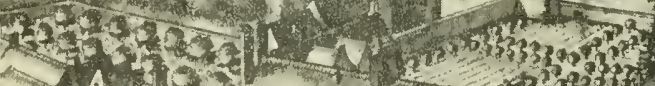

$\frac{3}{4}$

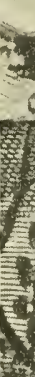

t.

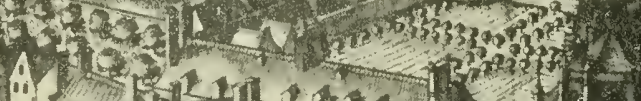

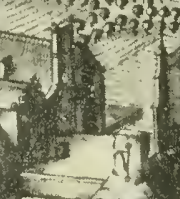

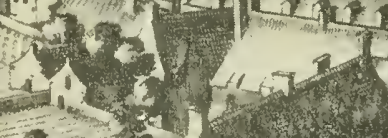

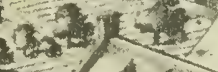
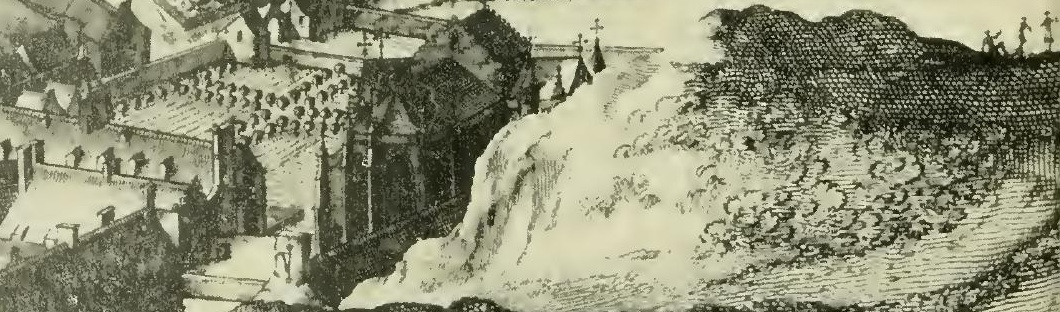

it 114
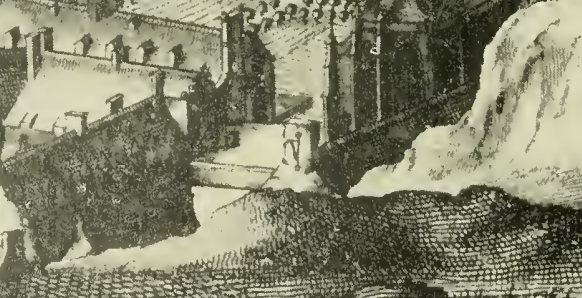

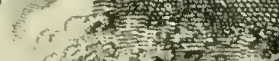

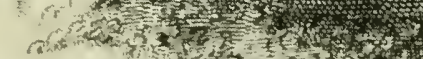

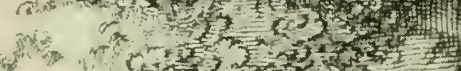

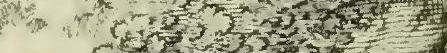

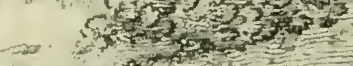
excer: 
Walker, the Vice-Master of Trinity, bought and presented to the University five acres of land in the centre of Cambridge, land on which now stands the Cavendish Laboratory and other University buildings, for the purposes of a Botanic Garden. Thomas Martyn, who had succeeded his father as Professor of Botany, sought the help of his friend, Philip Miller of Chelsea, in the layout of the Garden, and Philip's son, Charles, was appointed the first Curator in I762. Miller however stayed only until $\mathrm{I} 770$ when he went to the West Indies and when Martyn took upon himself the duties of Curator. He himself left Cambridge in 1776 , but, because he was still University Professor of Botany and Walker Reader in Botany, returned to Cambridge almost annually for the next twenty-four years to give courses of lectures. Not unnaturally, under these circumstances, the Cambridge Garden got into poor shape and it was not until the I9th century was well advanced that real progress was to be made.

The year I662 marked the turning point in the career of one of Cambridge's most distinguished sons, one of the greatest naturalists of the seventeeth, or, indeed, of any other, century, John Ray. A blacksmith's son, born in I628, Ray had a brilliant career as a student in Cambridge where he pursued theological studies and was ordained as a minister in I660--the year in which he published his first botanical work, ${ }^{\mathbf{1}}$ a catalogue of the plants growing in the neighbourhood of Cambridge, a catalogue of great significance since it was virtually the first British 'local Flora' since the short lists of British plants which the apothecary Thomas Johnson had published thirty years earlier. Ray also held a Fellowship in Trinity, but, refusing to assent to the Act of Uniformity, he had to resign it in I662 and from this time forth, until his death in 1705 , devoted himself to the study of plants and animals. Beginning in $\mathrm{r} 658$ when he travelled into the Midlands and North Wales, in search of plants, he made a series of botanical journeys which covered almost the length and breadth of Britain and which gave him a knowledge of British plants surpassing by far that of any previous naturalist. In I66r he paid his first visit to Scotland, and was not greatly impressed.

They are not very cleanly in their houses, and but sluttish in dressing their meat .... they have neither good bread, cheese or drink . ... their butter is very indifferent, and one would wonder how they could contrive to

I CATALOGUS PLANTARUM CIRCA CANTABRIGIUM. 
make it so bad .... they have hardly any bellows, or warming pans . . . . the people seem to be very lazy, and may be frequently observed to plough in their cloaks .... they lay out most they are worth in cloaths and a fellow that hath scarce ro groats beside to help himself with, you shall see come out of his smoky cottage clad like a gentleman. ${ }^{\text {I }}$

Still, Ray visited the Bass Rock where he saw gannets, guillemots and black guillemots, kittiwakes and shags, as well as the Wild Beet Beta maritima, the Scurvy-grass Cochlearia officinalis, the Sea Campion Silene maritima, and the Tree Mallow Lavatera arborea. $\mathrm{He}$ came to Leith and to Edinburgh, where he saw the Castle, Heriot's Hospital and the College-but not, apparently, the Botanic Garden. He went to Stirling by Linlithgow, and then on to Glasgow-'the second City in Scotland, fair large and well built, cross-wise, somewhat like unto Oxford'-then south to Hamilton and on to Douglas in Lanarkshire, where on Lowther Hill he saw the Alpine Clubmoss Lycopodium alpinum, past the Leadhills to Dumfries, and south to Carlisle.

By this time Ray was a Fellow of the Royal Society and had made the acquaintance of Thomas Willisel who was professionally employed by the Society as its collector of plants, animals and minerals. In I670 Willisel had added Lychnis viscaria, the Red German, or Viscid, Catchfly, to the British flora, when he found it on the cliffs of Samson's Ribs in Edinburgh, and Ray had recorded the find in his catalogue of plants published in the same year, the catalogue which sums up existing knowledge of the British flora. Ray made his second journey to the North in 167I, accompanied by Willisel, finding the London Rocket Sisymbrium irio, on the walls of Berwick and, two miles from Berwick, a plant new to science, Tofieldia pusilla the Scottish Asphodel, as well as the Northern Shore-wort Mertensia maritima which Willisel had discovered the year before. Thus was the discovery of the British flora being pioneered. Not until I690 was the first British Flora to be published, Ray's sYNOPSIS STIRPIUM BRITANNICARUM, a work which was to remain without rival until $I 762$ and the appearance of Hudson's FLORA ANGLICA which, though an excellent compilation of existing knowledge of the British flora, contains only a few Scottish records.

Ray journeyed not only in Great Britain. Immediately on leaving Cambridge he travelled on the continent, in France, Holland,

I Ray in a letter to his friend Willughby: CORR. p.3. 
Germany, Switzerland and Italy, frequently accompanied by his friend, the amateur zoologist Francis Willughby, and thereby laid the foundation of his contributions to a system of classification and structure of the plant kingdom as a whole which he was to present to the world in his METHODUS PLANTARUM NOVA of I682.

The great value of Ray's system, seen in perspective today, is his emphasis on general resemblance as the basis of classification. He rejected the singling out of one particular feature and insisted that 'the likeness and agreement of the principal parts, root, flower and its cup, seed and its vessel' must be the true criterion for systematic botanists. His own application of this principle in his system is less important than the principle itself and has mainly an historic interest. Like Morison, he owed much to Caesalpino and retained the ancient and artificial division into trees, shrubs and herbs, though he can claim to be the first to establish the two classes Dicotyledons and Monocotyledons into which the Angiosperms (ie the flowering plants excluding conifers and their allies) are still divided. ${ }^{I}$

Ray's greatest contribution to botany was his HISTORIA PLANTARUM GENERALIS, the first part of which was published in I686 and the last in I704, the year before he died. One of Ray's contemporaries, Plukenet, described it as 'the best medium to reach Heaven, better than the divinity of the schools'. Not only did it contain a description of all known plants, but a general introduction to the science of botany as well, including what was then known of anatomy and physiology, proving that Ray's interests extended much further than plant description and classification. By experimenting on the movement of sap in trees he foreshadowed the work of Stephen Hales in the following century. Equally important, his speculations on the sexuality of plants were given experimental proof by the German botanist Camerarius, who, in I688 was made Director of the Botanical Garden in Tübingen, and experimented with mulberry trees, Dog's Mercury, Castor-oil and maize.

In I736, nearly 30 years after Ray's death, the so-called 'sexual system' of classification of Linnaeus was made known to the world and was to be introduced into England by John Hill-herbalist, gardener, actor, dramatist, poet, novelist, journalist, doctor, and vendor of quack medicines-in his FLORA BRITANNICA of I760. Eight years later the system was adopted in the 8th edition of Philip Miller's GARDENeRs Dictionary. As we have seen, however, the system was not adopted in Edinburgh where Alston

I Gilmour, BRITISH BоTANISTs, (I944). 
attacked it bitterly for the very simple reason that he strongly denied the existence of sex in plants.

Apart from the development of botanic gardens, apart from the development of the first systems of plant classification and the beginnings of the discovery of the British flora, the first hundred years in the history of the Royal Botanic Garden in Edinburgh were tremendously important ones in the history of botany in Britain and abroad. Great advances in the science were made through increasing use of the microscope. In 1665, five years before the formation of the Edinburgh Garden, Robert Hooke, one time assistant to Robert Boyle whom he aided in the construction of his air pumps, the greatest mechanic of his age, as well as a botanist, physicist, chemist and philosopher, and true investigator of nature, published his MICROGRAPHIA. It was a remarkable assemblage of all manner of observations made with his microscope of which he had considerably increased the magnifying power. Some of the most interesting of the observations of this 'melancholy, distrustful and jealous' Curator of the Royal Society are those on sections of cork. Hooke found that the cork was all perforated and porousand the pores he called 'cells' and estimated that there were about twelve hundred millions of them to the cubic inch. Thus it was Hooke who was the first to apply the term cell to the unit of plant structure.

For years, Anthoni van Leeuwenhoek, the Dutch cloth merchant and wine taster who lived most of his long life $\left(\mathrm{I}_{32}-\mathrm{r} 723\right)$ in Delft whence he corresponded with the Royal Society in London, devoted all his spare time to lens grinding and the making of microscopes of which he is said to have constructed over four hundred, twenty-six of which he bequeathed to the Royal Society. With his microscopes he discovered the pitted vessels in the wood of plants, and protozoa and bacteria-though he did not recognise these as such.

Using the newly invented microscope, Marcello Malpighi, born in I628 near Bologna in which University he studied and in which he became a professor until I69I when he retired to Rome to become private physician to the Pope, made discoveries in the anatomy and physiology of plants, revealing, among much else, the stomata (breathing pores) on leaves-and moreover understanding their function. His great work on the anatomy of plants, the ANATOME PLANTARUM, was published in 1675 , and, jointly with the publications of another doctor, laid the foundations of the science of plant anatomy. 
The other doctor was Nehemiah Grew. Born in Coventry in I64I, educated at Pembroke College, Cambridge, and subsequently at Leiden where he received the degree of Doctor of Medicine in I67I, Grew practised medicine in Coventry, and later in London where he became secretary of the Royal Society in 1677 . Whilst in his early twenties Grew was drawn to the study of plant structure and in I672, two years after the founding of the Edinburgh Garden, the Royal Society published his first work on this subject, THE ANATOMY OF Vegetables Begun, in which he described the structure of the bean seed, inventing the term 'radicle' for the embryonic root, the word 'plume' for the embryonic stem we now call 'plumule', and using the word 'lobes' for what are now called seed leaves or 'cotyledons', as well as describing the vernation of leaves and methods of bud protection. Most of these observations were made with the naked eye. Soon however Grew was publishing his observations made with the improved microscope; a work on the anatomy of roots in I673, the COMPARATIVE ANATOMY OF TRUNKS, dealing with the structure of stems, in I675, and in I682 the ANATOMY OF PLANTS. With the facilities available to them, Grew and Malpighi advanced the science of anatomy as far as was possible at the time.

In like manner the science of plant physiology was pioneered by a minister of the Church. At the age of thirty-two, in I709, Stephen Hales resigned a Fellowship at Corpus Christi College, Cambridge, to become perpetual curate at Teddington where he was the friend and neighbour of Pope. On I3th March 1718 he was elected a Fellow of the Royal Society and ten days later 'the Rev Mr Hales informed the President that he had lately made an experiment upon the effect of the sun's warmth in raising the sap in trees. Mr Hales was desired to prosecute these experiments and had thanks for communicating his first Essay.' Hales prosecuted his experiments at Teddington for close on ten years and then, in 1727 , published his VEGETABLE STATICKS which deals with the movement of sap in plants. A study of transpiration forms the first part of the book and Hales invented methods of estimating this phenomenon which were to be in use many years later. Root pressure is then discussed as a factor in the raising of the sap in the stem, and again be was the first to measure quantitatively this now well known function. Sachs, Professor of Botany in the University of Würzburg, wrote of him that he had the art of making plants reveal themselves; by experiments carefully planned and cunningly 
carried out he forced them to betray the energies hidden in their apparently inactive bodies. ${ }^{\text {I }}$ By recognising that air may be a source of food in plants, Hales was the forerunner of such workers as the Dutchman Ingen-housz and the Swiss de Saussure, the founders of the central principle of plant nutrition.

Hales' work was greatly to influence botanical teaching in Edinburgh during the latter half of the I8th century.

I F. G. J. von Sachs, HISTORY OF BOTANy (1890). 


\section{PART TWO}

\section{Botany at Leith Walk}

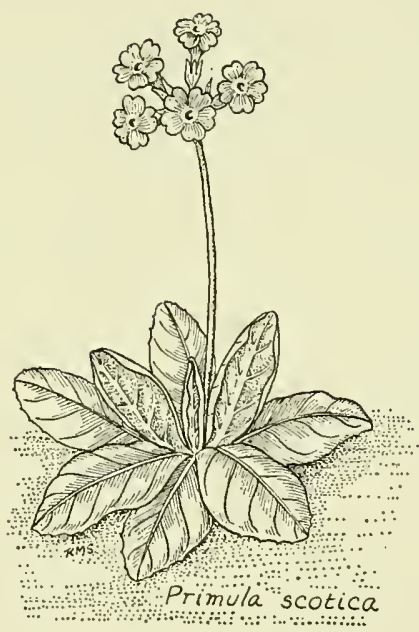





\section{烈}

\section{CHAPTER SIX}

\section{John Hope}

ALSTON WAS SUCCEEDED BY HIS DISTINGUISHED STUDENT John Hope (Plate I), born in Edinburgh in 1725, the son of Robert Hope, an Edinburgh surgeon, whose father had risen to be one of the Senators of the College of Justice with the title of Lord Rankeillour. John Hope had been educated at the school at Dalkeith, at that time and for many decades later, one of the finest schools in Scotland, before entering the University of Edinburgh as a medical student. Under Alston's influence his interest in botany quickly developed to the extent that he interrupted his medical studies to study botany in Paris under Bernard de Jussieu (I699I777) a member of the family which for close on a century and a half held influential appointments in the Royal Gardens, in the Museum of Natural History, and in the Académie des Sciences. Bernard was Professor of Botany and Demonstrator at the Royal Garden in Paris, where he arranged the plants according to the system of Linnaeus. Later he varied the original layout so much that the arrangement became much more his own than that of Linnaeus and was in fact elaborated by his nephew, AntoineLaurent, as the de Jussieu system.

In Paris Hope found himself in a somewhat strange position; he was a pupil of one of the strongest advocates of the Linnaean system of classification, whereas in Edinburgh he had been a pupil of Alston who was one of the strongest opponents of Linnaeus's ideas. Before he could state where his allegiance lay, his father died and he had, perforce, to return to Scotland, graduating in medicine in the University of Glasgow in 1750, and, after election to the Royal College of Physicians, beginning medical practice in Edinburgh. Though apparently a conscientious practitioner for the next few years all his spare time was devoted to botany. Then, in 1760 , Alston died and the joint Professorships of Botany and Materia 
Medica in the University of Edinburgh became vacant. To these vacant Chairs Hope was appointed, as well as, in I76I, to the post of King's Botanist in Scotland and to the Superintendentship of the

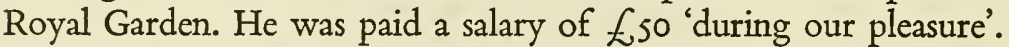

Until I 768 Hope taught materia medica in the winter and botany in the summer always being fully aware of the work of others both in Britain and on the Continent. Thus he was familiar with the pioneer work on the physiology of plants of the curate of Teddington, Stephen Hales, and of the French dendrologist Henri Louis Duhamel de Monceau. He realised, chiefly through their work, that botanical matters were no longer specially related to medicinal plants and that the teaching of botany should no longer be specially related to the teaching of materia medica. As a result, in 1768 , he was successful in arranging for the separation of the teaching of these two subjects and for the creation of a new Chair in Materia Medica of which Dr Francis Home was made the first Regius Professor-but without a salary. Hope retained for himself responsibility for Medicine and Botany in a new Regius Chair and the office of King's Botanist and Superintendent of the Royal Garden. The Commission which Hope received from the Crown on 2nd May I768 reveals two interesting points regarding his appointment. First, this Commission for the first time makes the Crown Professorship of Botany in the University. Second, the office of King's Botanist and Superintendent of the Garden is made a life appointment, instead of one during the Sovereign's pleasure, at a salary of $£ 50$ :

.... taking into our Royal consideration that it would be for the advancement of learning, and advantage of our University of Edinburgh, that the two Professorships of Botany and Materia Medica be separated and each taught by its respective Professors as the other branches of Medicine in the said University, and that both are presently vacant by the resignation of $\mathrm{Dr} J o h n$ Hope .... appoint John Hope, Doctor of Medicine during all the days of his life, to be Regius Professor of Botany in the University of Edinburgh, and give and grant unto him the oversight, care, and direction of the Royal Botanic Garden lately established there, and to be His Majesty's Botanist within that part of the foresaid United Kingdom, with all rights, immunities, and privileges which belong to any other Professor within the said University, or that he or any of his predecessors in office hitherto enjoyed .... and grant unto him during all the days of his life the yearly salary of $f, 50$ sterling.

Alston had felt the limitations of the existing Botanic Gardensparticularly the deleterious effects of atmospheric pollution-and 
had made many fruitless efforts to obtain from Government adequate funds for establishing a new Garden. In succeeding where Alston had failed lay Hope's greatest achievement from the point of view of the history of the Botanic Garden. Judiciously using his family influence, first with the Earl of Bute and later with the Duke of Portland, Hope was successful in securing a new site for the Botanic Garden, in Leith Walk, in transferring there, in 1763 , the plant collections from the Trinity and Holyrood Gardens, and in obtaining from the Crown a permanent endowment for the new Garden. Although the endowment was only firg 3s. od., this last action was greatly to influence botanical education in Scotland.

The new Garden, the boundaries of which Hope marked with stakes of the Huntingdon Willow Salix alba, occupied some $s$ acres on the west side of Leith Walk on a site where now stands Haddington Place (Plate IIIa), and was divided into two. The east section Hope called the School of Botany and in it the plants were systematically arranged. On each side of this area were placed the medicinal plants, shrubs and trees. In the west section were the conservatories, the pond for aquatics, and a plantation which Hope called the Sylva Botanica and which consisted of hardy trees in the shelter of which less hardy plants grew. The conservatories formed a frontage of $140 \mathrm{ft}$ and consisted of a greenhouse in the centre, with a hothouse at either end connected with the central portion by a passage. They contained several interesting and even outstanding plants. There was a splendid specimen of the Star Anise Illicium anisatum, an ally of the magnolia and a native of Japan and Formosa, with greenish-yellow star-shaped flowers; there were plants of the banana, tea, coffee; there was the remarkable Desmodium gyrans, the Telegraph Plant of the East Indies whose leaflets exhibit strange diurnal movements, which phenomenon, as well as many others, Hope demonstrated to his students.

From a manuscript copy of Hope's LECTURES in the Library of the Royal Botanic Garden it is clear that he was familiar with the work of some of the foremost experimentalists of the day for their names are frequently mentioned in his lectures; with the work of Stephen Hales who was the first to conduct experiments on plants and to get quantitative results; with the work of Duhamel on the physiology of trees; with the work on the physiology of leaves by the Swiss entomologist Charles Bonnet; with the work on the flow of sap, and of other matters, of Edme Mariotte. But Hope was by no means content simply to quote such work; continually he was 
describing experiments he himself had devised, experiments on growth in length and in thickness, on the ascent of sap, on the much discussed circulation of sap, on the position assumed by leaves, on the responses of plant organs to light and to gravity, on the healing of wounds, and on many another phenomenon. Thus Hope was an I8th century plant physiologist of no mean order.

Hope's experiments were seen by, and explained to, his students. Whenever possible his lectures were illustrated with living material and, when this was not available, by diagrams. There are some 80 drawings, about half being duplicates, in the Royal Botanic Garden Library. In spite of their small size, mostly Io x I3 inches, they were used to illustrate Hope's lectures. Most seem to have been drawn by J. Lindsay from nature, in red chalk, and carefully copied in sepia or some dark coloured water-colour. There are drawings illustrating the sleep movements of clover, Desmodium and Cassia (Plate $\mathrm{mb})$. There are drawings illustrating the action of light and of gravity on plant organs. For instance, Plate rva $\& b$ shows the stem of Asperula odorata curving upwards against the force of gravity when growing respectively in the open air or when faintly lighted from below; Plate IV figure $\mathrm{c}$ shows, on the other hand, that when the plant is well illuminated from below by means of a mirror the stimulus of light is stronger than the stimulus of gravity and thus straightens out the geotropic curve; Plate IV figure $d$ is another way of illustrating the stronger influence of light over gravity.

These experiments were made in June 1780 and yet the facts were not known to plant physiologists until nearly roo years later when they were published by H. Muiller Thorgan in FLORA (I876) and by Elfving in ACTA SOCIETATIS SCIENTIARUM FENNICAE (I880-83). Clearly Hope's regime was one of experimentation in Edinburgh. It was also an age of experimentation elsewhere for in 1774 Joseph Priestley discovered oxygen and in 1779 demonstrated conclusively that plants in sunlight give off oxygen. Moreover, in the same year John Ingen-housz, who had recently come to England from Vienna and knew of Priestley's work, carried out 500 experiments and published his EXPERIMENTS ON VEGETABLES in which the processes of respiration and of carbon assimilation were clearly distinguished and defined.

Hope lectured five days a week during the three summer months of May, June and July. In addition to his experimental demonstrations at the Garden he taught the history of botany, the nature 
and uses of many of the plants in the Garden, and unfolded the botanical system of Linnaeus for by this time he was as strong an advocate of the Linnaean system of classification as Alston had been an opponent. In fact, apart from plant physiology, systematic botany was Hope's other great interest; systematic botany, moreover, conducted in the field. He encouraged his students to explore and investigate the flora of Scotland and annually gave a gold medal for the best student's herbarium. There can be no questioning the fact that Hope and his students were the pioneer investigators of the Scottish flora for, from Hope's notebooks, it is quite clear that his students collected widely in Scotland, not only on the mainland but in Arran, Skye, Mull, Orkney and Shetland as well, and Hope, without doubt, greatly influenced Lightfoot when the latter was planning the itinerary of his visit to Scotland in 1772 . Lightfoot, in the preface to his FLORA SCOTICA of 1778 (though the title page is dated I777), acknowledges his indebtedness to several scientists and says that Hope 'not only favoured me with the sight of his copius Herbarium, but permitted me the use of his notes and observations, the result of a long enquiry.' The whereabouts of the 'copius Herbarium' is not now known but from Hope's notebooks it is clear that he and his student colleagues had collected quite a number of Scottish plants long before they had been found by others and published as new records for the Scottish or British flora.

In the Library of the Botanic Garden are two small notebooks which belonged to Hope. One of these contains a number of records, of 1764 and 1765 , of stations for plants in the vicinity of Edinburgh and in other parts of Scotland. Hope wrote on the fly-leaf at the beginning of the book, 'List of plants growing in the neighbourhood of Edinburgh, collected in flower 1765 as a sketch of the CALENDARIUM FLORA OF EDINBURGH.' The writing of the manuscript is not that of Hope and no doubt he was not the compiler of the list, but it is clear that he had examined the list, interpolated certain stations, and pointed out dubious records. Upon the first page there is the heading 'A list of plants as they were collected and prepared during the year 1764 , with ye place of growth.' Hope interpolated the words 'in flower' after 'plants', and the list continues in calendar form from March 1764 until January 1765 , when a couple of pages are blank. The calendar starts again on I4th May and continues until 3oth October 1765 under the new heading 'A calendar of plants as they were found 
and prepared in the year I765.' The first portion of the list is of plants found in the vicinity of Edinburgh; the second portion contains a large number of citations of localities distant from Edinburgh.

The second notebook is of more significance especially in view of the unknown whereabouts of Hope's herbarium. On the fly-leaf Hope wrote 'A Catalogue of British Plants in Dr Hope's Hortus Siccus, I768'; the catalogue is also in Hope's handwriting, with occasional interpolations, and there are entries with dates subsequent to I768. Several of Hope's plants undoubtedly form the first records for the Scottish or British flora. For instance James Dickson is usually credited with the first finding of Veronica alpina the Alpine Speedwell 'In montibus prope Garway Moor, et in Ben Nevis' in $1789^{\mathrm{I}}$ and yet it was in Hope's herbarium in 1768 , collected on Ben Nevis in 1767 by Hope's students, Dr de la Roche and the brothers Fabricius. Lightfoot, during his Scottish tour of I772, is generally considered to have discovered the Alpine Poa grass Poa alpina, the Creeping Azalea Loiseleuria procumbens, the Spurge Euphorbia esula, the Creeping Spearwort Ranunculus reptans, the Pyramidal Bugle Ajuga pyramidalis, the Creeping Lady's Tresses orchid Goodyera repens, and the dwarf birch Betula nana-and yet all are listed by Hope as being in his herbarium in 1768 . Poa alpina had been found on 'Ben Crooken by Mr Oaks in 1767 on whose authority I insert it.' Loiseleuria procumbens is stated by Hope to grow 'plentifully on a hill in Glen Criven on Scaraber Caithness on benevalich Sutherland etc.' Mr Benj. Charlesworth is credited with having found Euphorbia esula in I768 growing 'plentifully on a bank South of Ld. Abercorn's', ${ }^{2}$ near to Edinburgh. Hope's specimens of Ranunculus reptans came from Loch Leven where later Lightfoot saw it growing, and his specimens of Goodyera from 'a wood opposite Moy hall south side of ye road to Inverness.' 'Sir James Naesmyth in the moors north of Loch Glash Rossshere' is the source of Hope's specimens of Betula nana. Of Eriophorum alpinum (now known as Trichophorum alpinum) Hope is 'uncertain from whence it came or where it was found.' It is remarkable that this exceedingly rare plant should have been in Hope's herbarium for it has been known only from one locality, Restennet Moss,

I Dickson, PLANTARUM CRYPTOGamicarum BRITANNIAB FASC. II (I790), and TRANS. IINN. SOC. II (I794), p.287.

2 Duddingston House. 
Forfarshire, where it was found by George Don and Robert Brown in I79I, but is now probably extinct.

$\mathrm{Mr}$ Gibb of Inverness is usually regarded as the discoverer of Primula scotica, on Holborn Head, near Thurso, in Caithness; yet Hope records it, under the name of Primula farinosa, 'along the coast of Caithness and Strathraven in moist pastures.' Of Ajuga pyramidalis, Lightfoot wroteI 'I am assured by the Rev Doctor Burgess of Kirkmichael that it is a native of Scotland but I have not yet learned the particular place of its growth.' Hudson ${ }^{2}$ is more specific and gives Ben Nevis as the locality-on the authority of Hope, who not only records the plant from Ben Nevis, but also states it to be plentiful in the burn of Killgower and Ord of Caithness.' Hudson could not have known of Hope's specimens of Carex limosa the Mud Sedge, for on p.409 of FLORA ANGLICA he records it 'In paludibus turfosis in comitatibus Eboracensi, Lancastriensi, Westmorlandico etc. passim.' Hope records it as having been collected by Mr Fabricius in 1767 but does not give a locality. James Brebner, in I884, has the credit for discovering Schoenus ferrugineus when he found it growing beside Loch Tummel, but apparently there were specimens in Hope's herbarium gathered in Skye where it has not been found since.

The finding of the Pipewort Eriocaulon septangulare, in Skye, by his pupil James Robertson (it had previously been found in Skye by Sir John Macpherson in I764), was the subject of one of Hope's few published botanical papers. ${ }^{3}$ Rather more important were his accounts in Volume 55 of the PHILOSOPHICAL TRANSACTIONS of the plants Rheum palmatum and Ferula asafoetida. Seeds of the Chinese Rheum Hope received in 1763 from Dr Mounsey, then Physician to the Empress of Russia. He sowed them out of doors in the Botanic Garden and soon had plants, with their ripened seeds, some $8 \mathrm{ft}$ high. On his death a stock of 3,000 plants between twelve and fifteen years old was found in an enclosure behind the Garden and the plant was widely grown in Britain for its medicinal uses. It has been one of the parents of the culinary rhubarbs of today. Though Hope did not have the same cultural success with the Ferula the plant nevertheless did grow in the Botanic Garden and did set viable seeds.

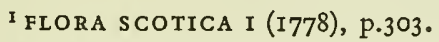

2 FLORA ANGLICA ed. 2 (I778), p. 249.

3 PHILOSOPHICAL TRANSACTIONS, LIX (I770), p.24I. 
Thus, although it is clear that Hope did not entirely neglect the study of medicinal plants, his interests were essentially in plant physiology and in systematic botany. Undoubtedly it was through his advocacy of Linnaeus's teaching that the Swedish botanist's doctrines gained so firm a hold in Britain. So great was his admiration for the Swede that, at his own expense, Hope erected in the Botanic Garden a monument to his honour.

One other monument Hope erected in the Botanic Garden, a memorial tablet bearing the words:

To the memory of John Williamson, who during twenty-five years of faithful service as Principal Gardener in this place, was no less respected for the good qualities suited to his station in life, than esteemed for eminent skill in his profession, this monument is erected by John Hope PB, I78 $\mathrm{I}$.

In John Williamson Hope obviously had a staunch and loyal worker in the laying out of the Garden in Leith Walk as well as a willing helper in his scientific work. Hugo Arnot, ${ }^{1}$ describing the Botanic Garden in I779 and speaking of its development, writes 'this rapid progress of the Garden was much owing to the skill and diligence of John Williamson, the Principal Gardener.' Of his collaboration in Hope's scientific work there is evidence, in the Botanic Garden Library today, in the form of a manuscript entitled A narrative of experiments made on trees in the Botanic Garden. The book contains an account of experiments carried out in I769, and the subjects of investigation were the movement of sap, the polarity of branches, the growth of the wood in the stem, and the relation of the parts of the flower to the ripening of the seeds. It seems clear that the observations and notes were made by Williamson under Professor Hope's direction.

The 'rapid progress of the Garden' was also no doubt partly due to the sums of money which Hope had been able to procure for developments in the Garden. In 1776, 6600 was granted as well as an additional annual sum of $£ 50$, and in 1783 a further $£^{100}$ was allowed.

Williamson died in 1780 and was worthily succeeded towards the end of $178 \mathrm{I}$ by Malcolm McCoig whose main interest seems to have been in systematic botany. He planned to publish a Flora of Edinburgh, as the following prospectus from Kerr's LIFE OF WM. SMellie, printer, Vol. 2, page 243, shows:

\footnotetext{
${ }^{1}$ Hugo Arnot, The His tory of EDINBURgh (1779), p.4I8, Footnote.
} 


\section{PLATE III}

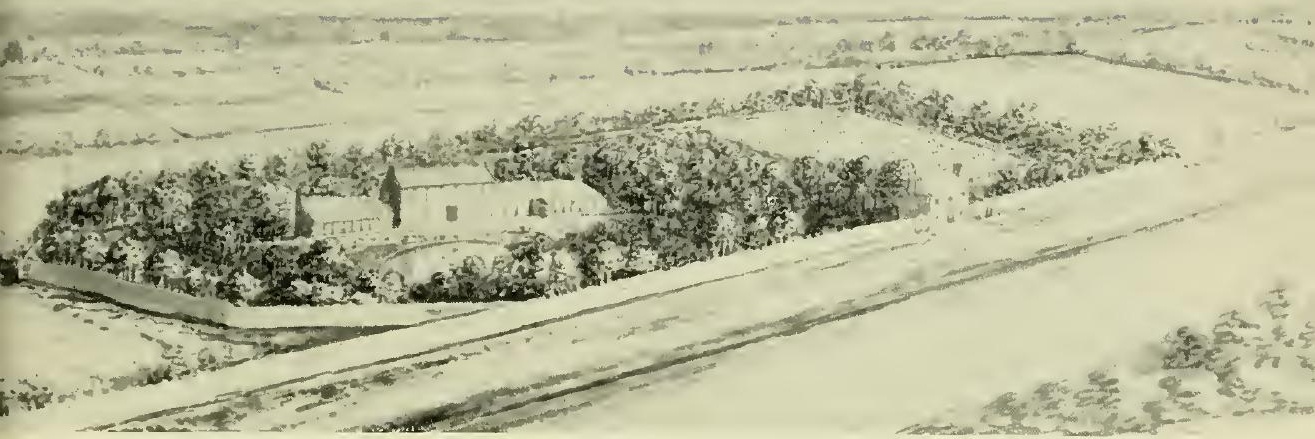

(a) The Garden on the site where now stands Haddington Place, about I 800

(b) Professor Hope's drawings illustrating the sleep movements of clover (i) and Desmoditm (ii) and Cassin(iii)

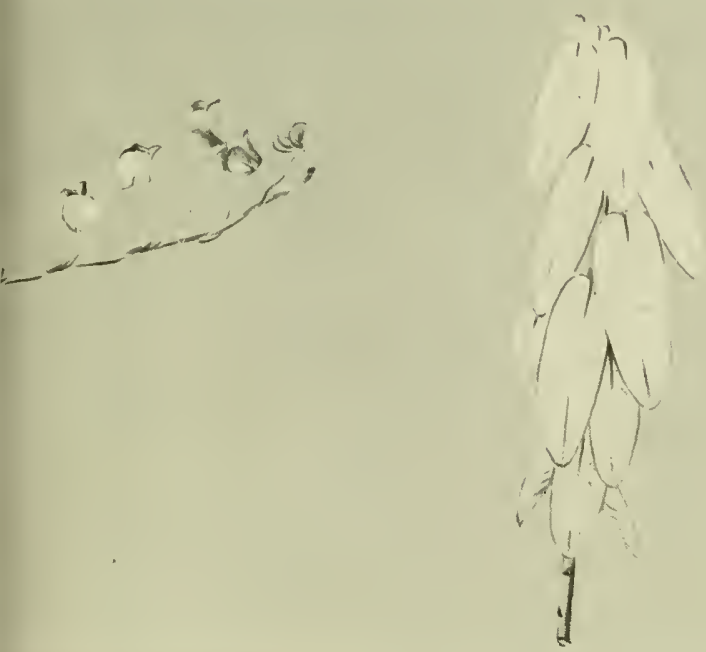

(i) (ii)

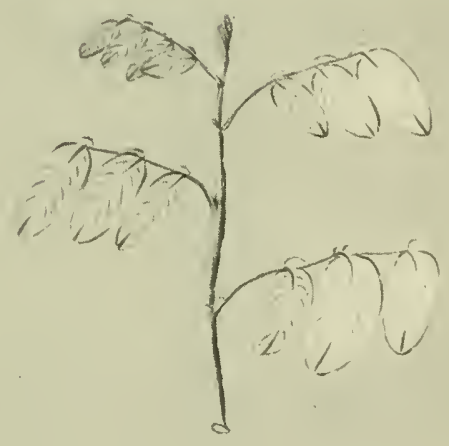

(iii) 


\section{PLATE IV}
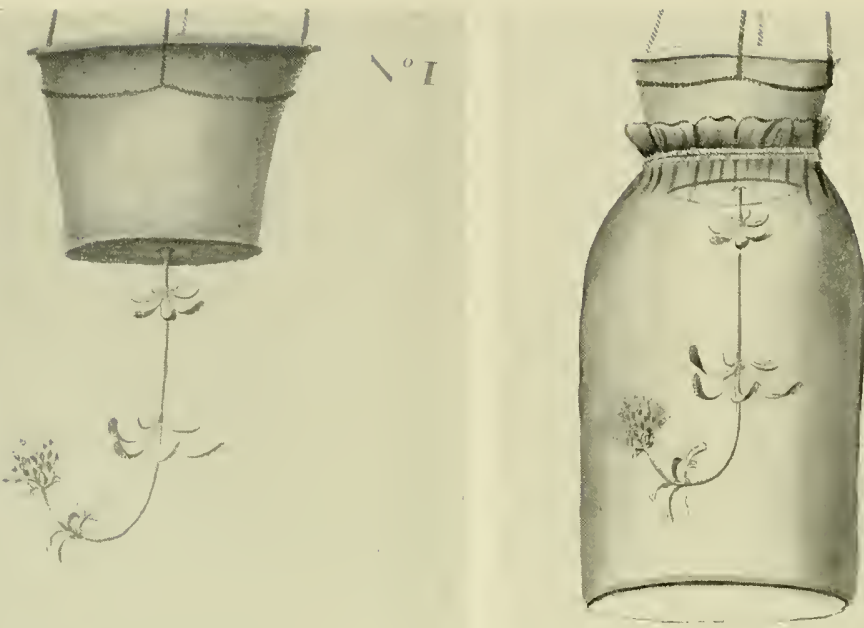

(a) and (b) Professor Hope's drawingsillustrating the stem of Asperula odorata curving upwards against the force of gravity
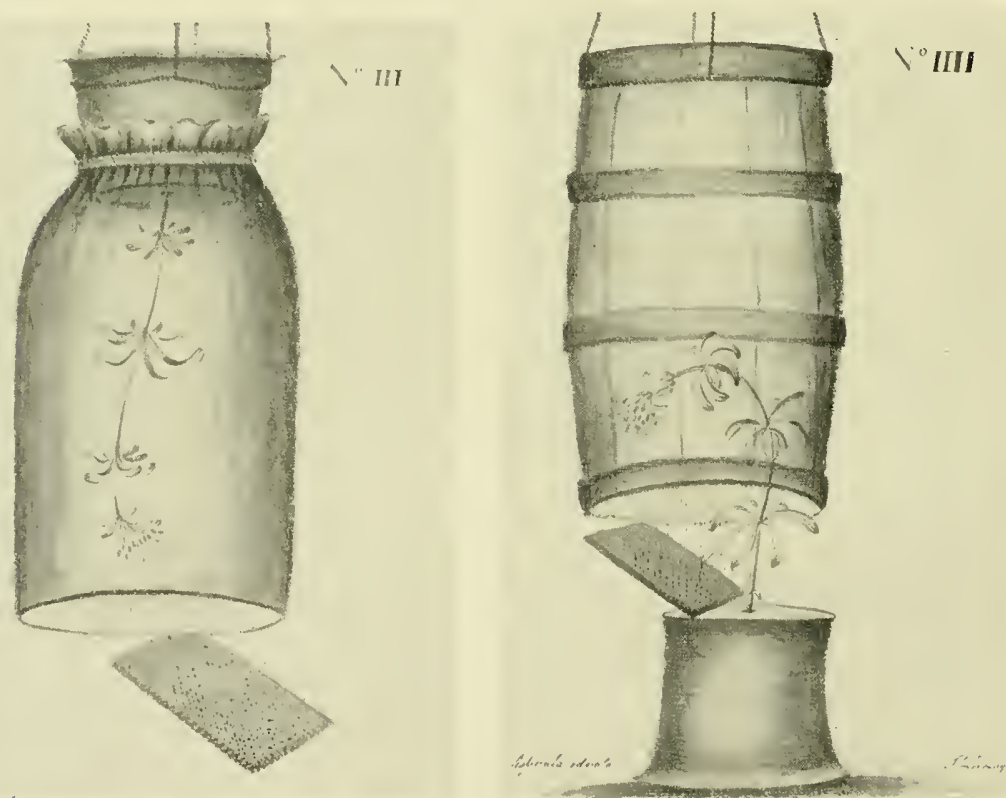

(c) and (d) Professor Hope's drawings illustrating the stronger influcnce of light over gravity 
The ensuing proposals for publishing a FLORA EDINBURGENSIS by Malcolm McCoig, Gardener to the Royal Botanic Garden of Edinburgh, was written by Mr Smellie, at the desire of the author, who, though an excellent gardener, and intimately versant in all the plants of the garden he had charge of, and a good memorial botanist, had not the advantage of a liberal education.

Proposals for publishing/FLora edinenburgensis / or / A Systematic Arrangement and Description of all the plants, those of the Cryptogamia Class excepted, which grow wild within fourteen miles round Edinburgh. / To which will be added, / Complete Catalogues of the Plants which are found on each of the islands of the Firth of Forth / By Malcolm McCoig,/ Gardener to the Royal Botanic Garden, Edinburgh.

Plan of the Work / At the beginning of every class, the several Orders and Genera will be enumerated, together with the short characters which distinguish one Genus from another, after the manner of Linnaeus. / Under each Genus, the several Species, with their trivial names and specific differences, will be comprehended. References will likewise be made to those authors who have given figures of the different species. To every species, the English name, its duration, time of flowering, its native soil, the particular places in which it is found, and a short English description will be subjoined.

Conditions / The work will be contained in one volume, 8vo, price Five Shillings in boards, to be paid on delivery of the Book.

It will be put to press as soon as a competent number of subscriptions are received.

The Flora, unfortunately, was not published, for McCoig died in I789, some three years after his Professor. Even so, he, with Williamson and Hope, had initiated a new botanical era in Edinburgh.

One of Hope's students also initiated a new botanical era in India. He was William Roxburgh, from Craigie in Ayrshire. Having studied in Edinburgh, by Hope's influence he was appointed Surgeon's Mate in one of the East India Company's ships. After making several journeys, in 1776 he accepted an appointment to the Company's Medical Establishment and was posted to Madras. In I78I he was transferred to Samulcotta, a remote hill station north of Madras. Here he cultivated spices experimentally and assiduously began to study the intensely interesting flora of the region. Employing a native draftsman he assembled a vast collection of drawings from which were selected the 300 used in the three large folio volumes of the PLANTS OF THE COAST OF COROMANDEL - the first part of which appeared in 1795 and the last not until I8I9 -four years after Roxburgh's death. This work was commissioned by the Directors of the East India Company and the editing was entrusted to Sir Joseph Banks assisted by Patrick Russell another medical officer on the Company's staff. 
On the death in 1793 of Robert Kyd, the founder of the Calcutta Botanic Garden, Roxburgh was appointed the Garden's Superintendent. At once he began to describe all the plants, indigenous to British India, of which he could procure specimens, and in 1813 , when he was forced to retire from India due to ill-health, he was able to leave for publication the manuscripts of his FLORA INDICA and of his HORTUS BENGALENSIS, the latter being an enumeration of the plants in cultivation in the Calcutta Garden. He also left over 2,500 admirable coloured drawings of species of plants indigenous to India. In this fashion Roxburgh was the first botanist to attempt to draw up a systematic account of the plants of India and his FLORA INDICA, the basis of all subsequent works on Indian botany, remained the only book of its kind until the publication of Sir Joseph Hooker's monumental fLORA OF BRITISH INDIA. Thus Roxburgh's influence on Indian botany was profound and without him the study of the economic products of India might have been put back for half a century. Moreover, the collection of plants he assembled at Calcutta put the Garden in the forefront of the world's great Botanic Gardens for in 20 years the number of species was increased from 300 to 3,500-1,500 of them named, described and illustrated by Roxburgh himself.

Another of Hope's pupils was Archibald Menzies who was born in Aberfeldy, Perthshire, in 1754 and who joined his elder brother Robert as one of Hope's gardeners. Under the Professor's 'genial and painstaking' influence Archibald Menzies became a keen student of botany. In 1778 he made a botanical tour of the Highlands and Hebrides; part of the collections he then made no doubt formed the private herbarium of grasses, sedges and cryptogams which is now incorporated in the Edinburgh Herbarium. He so impressed Hope that the latter encouraged him to take the University's medical course and, on his graduating, helped him to obtain a medical appointment in Caernarvon. From here he entered the Royal Navy as Assistant Surgeon and took part in Rodney's victory in I782. His introduction to the flora of North America, with which his name is so closely associated-Sir J. E. Smith named the North American ericaceous genus, Menziesia, after him-was due to his transfer, on the declaration of peace, to the Halifax Station, Nova Scotia, where he remained until 1786.

On his return Menzies called upon Sir Joseph Banks, the President of the Royal Society, with whom he had previously corresponded, armed with a letter of introduction from Hope and 'a small box 
of Arcadian plants'. Through Sir Joseph's influence he was appointed Surgeon to a "private adventurer, now fitting out at Deptford to go round the world', under Captain Corbett, and was allowed to collect, though he states in one of his letters that it is not allowed for the ship's company to trade or barter for any curiosities'. This expedition occupied three years and at its completion so high was his botanical reputation that he was appointed by the Government to be Naturalist on the DISCOvery during Captain George Vancouver's voyage round the world from I790 to I795. From this expedition he introduced to Britain the Monkey Puzzle, Araucaria araucana. Later he was in the West Indies, where he appears to have completed his term of service in the Navy. Thereafter he settled in London, followed his profession of doctor and surgeon, and there died in 1842 at the advanced age of eighty-eight.

Hope died in I786, at the age of sixty-one, his name commemorated for all time in the genus of trees from South China, Southeast Asia and Indo-Malaya-Hopea. It was William Roxburgh who so honoured him. 


\section{CHAPTER SEVEN}

\section{Daniel Rutherford and \\ his Gardeners}

IN ACCORDANCE WITH TRADITION THE CHAIR VACATED BY Hope was filled by the election of another medical practitioner in Edinburgh. He was Daniel Rutherford, born in Edinburgh on 3rd November 1749, the son of Dr John Rutherford who as Professor of Medicine was closely associated with Alston and others in the formation of the Edinburgh Medical School. The terms of his appointment to Hope's Chair are interesting. On 25th November I786 he was made Professor of Medicine and Botany in the University-by the Town Council. On 2oth December 1786 he was made Regius Keeper of Botany in the University, Keeper of the Botanic Garden and King's Botanist with "the salary, f,so sterling money, to commence from the 25th day of November last, the day on which the said Dr Daniel Rutherford was elected to a Professorship in the said University by the Lord Provost, Magistrates and Council of the City of Edinburgh'. For the first time the Crown appointed as its Professor and Keeper of the Royal Garden the man who already held the office of Professor in the University and it is the only instance in which reference is made in the Commissions to the appointment made by the Lord Provost and his colleagues.

After graduating MA Rutherford began his medical studies in the University of Edinburgh and was fortunate to be able to study under William Cullen and Joseph Black, two celebrated chemists, the former having founded the Medical School in Glasgow before

I Privy Seal Register of 1786. 
moving to Edinburgh as Professor of Chemistry and as one of the supreme teachers of medicine in Britain. In 1772 Rutherford was granted his MD diploma, his thesis being entitled De aero fixo dicto aut Mephitico. This important piece of work clearly established the distinction between carbon dioxide and nitrogen though Rutherford did not give the latter its name. By reason of the fact that he described his experimental work carefully and lucidly he came to be regarded as the discoverer of nitrogen. However, six months before Rutherford's thesis was published, Joseph Priestley, famous for his discovery of oxygen and of its production by plants, had covered the same ground, albeit less methodically, in a memoir published in the PHILOSOPHICAL TRANSACTIONS. Rutherford appears not to have known of Priestley's work.

Having published his valuable paper Rutherford travelled to England, journeyed to France in I773, and thence to Italy. In I775 he returned to Edinburgh and began to practise medicine becoming a licentiate of the Royal College of Physicians of Edinburgh in I776 and a Fellow the following year. Twenty years later he was to become President of the College.

Thus to the Chair of Medicine and Botany one who was fundamentally a chemist was appointed, a circumstance which today would not seem so strange. Of course it could be argued that one experimenter with plants was succeeded by another; but whereas Hope had always been interested in plants as plants, Rutherford had been interested in them simply as objects for his experiments in relation to the chemistry of the atmosphere. As a result, during his regime, though far reaching advances were being made in the world of botany in England and in Europe, botanical science in Edinburgh ceased to move forward with the impetus which Hope had given it. Rutherford's teaching seems to have followed the pattern of Hope and showed no new developments. Neither does he himself appear to have encouraged field botany among his students as Hope had done. Possibly the reason for this was that he suffered from gout-apparently from the age of ten-and did not find it easy to explore on foot the Scottish countryside. Even so, field botany and the exploration of the Scottish flora did prosper and were prosecuted vigorously by Rutherford's Principal Gardeners.

During his 33 years of office in the Leith Walk Garden Rutherford was assisted by six Principal Gardeners-Malcolm McCoig who had been appointed by Hope, Robert Menzies, John McKay, George Don, Thomas Sommerville, and William McNab. 
Of Menzies little is known beyond that he was the elder brother of the distinguished traveller Archibald Menzies and that he succeeded Malcolm McCoig in I789 and was in turn succeeded, in I80o, by John McKay, a name well-known in the annals of Scottish botany.

Much more is known about one of Menzies's foremen, John Tweedie of Lanarkshire, who before being employed at the Royal Botanic Garden was foreman at Dalkeith Palace Gardens. He developed a taste and aptitude for landscape gardening and about I 800 left Edinburgh for Castle Hill, Ayrshire, there to create a new garden. When once this was satisfactorily established he greatly improved three other estates, the last one at Eglinton Castle. By this time, I825, he was fifty, and, having heard of the botanical riches of South America, departed for Buenos Aires where he spent the remaining thirty-seven years of his life, practising his trade of landscape gardener, undertaking several remarkable botanical expeditions, some of them hazardous in the extreme, corresponding with botanists interested in the South American flora notably with Sir William Hooker whose accounts of the flora owe much to Tweedie and who published Tweedie's journals in the JOURNAL of Botany, and introducing South American plants into Britain.

Tweedie it was who introduced some of the species of Verbena from which the present garden verbena, $V . \times$ hybrida, has been developed; the purple, lilac or red $V$. phlogiflora, then called $V$. tweediana, in I834; the white-flowered and fragrant $V$. platensis in 1837 , when it was called $V$. tencrioides; these, with the scarlet $V$. peruviana, are the parents of $V . \mathrm{x}$ hybrida of which there are at least 130 named cultivars in the trade, probably the two finest being 'Lawrence Johnston' and 'Firefly', both with crimson or scarlet flowers. Brunfelsia latifolia, whose fragrant lavender flowers quickly turn to white, was raised from seeds sent to the Glasnevin Botanic Garden in Dublin by Tweedie in I840, when it was called Franscicia latifolia. The fragrant white or creamy-white flowered climber, the Chilean Jasmine, Mandevilla suaveolens, was introduced by him in 1837, and another climber, with yellow flowers, Bignonia unguis-cati, in 1838 , when it was known as Bignonia tweediana. And in I843, at Glasnevin, and from the mountains of Rio Grande, Calliandra tweedii was raised and was soon to show its flowers, each a mass of long scarlet stamens. The genus Tweedia, named by Hooker for a group of South American plants, fittingly honours 
the name of this very remarkable man, several of whose specimens are in the Herbarium of the Royal Botanic Garden.

John McKay, successor as Principal Gardener to Robert Menzies, was born at Kirkcaldy on Christmas Day I772. His father, Hugh McKay, was a professional gardener and John and his younger brother James Townsend, later famous for his work on the flora of Ireland, apparently inherited their love of plants from him. Whilst the boys were still young the family moved to Inveresk, where, by the age of fourteen, John had made a collection of rare garden and hothouse plants and had become familiar with the flora of the Lothians. At the beginning of I79I, when he was eighteen, he found congenial employment in Dickson's Nurseries in Leith Walk, at that time the most extensive and best conducted nursery in Scotland, and during part of the summer assisted Robert Menzies in the Botanic Garden in preparing the material for Dr Rutherford's lectures. Then for a brief spell he was employed in the historic gardens and beautiful pleasure grounds at Hopetoun House, gaining experience in landscape gardening - and in the evenings taking lessons in mathematics at Queensferry-before returning to Messrs Dickson, towards the close of $\mathrm{I} 792$, to act as clerk to their nurseries and to take charge of their more rare plants. Here he remained for several years, a hard and conscientious worker and a diligent student of botany.

Obviously the Dicksons were generous employers for during the summer months McKay was enabled to make lengthy botanical excursions into the highlands and islands of Scotland. Sometimes he journeyed alone; at others he was in the company of the illustrious George Don, the clock and watch maker of Forfar; sometimes he was away for as long as I6 weeks, continuously botanising, and continuously exposed to inclement weather. Always he returned home laden with his collections which provided him with material for study during the winter months and many of which he grew in the nursery. Here, on a special plot of ground, he cultivated an extensive collection of plants indigenous to Scotland and began to specialise in the culture of the rarer alpine plants. In this fashion he established himself as a botanist and caught the eye of Dr Patrick Neill of Cannonmills Lodge, Edinburgh, who recommended him to James Edward Smith, the President of the Linnean Society, for election as an Associate of the Society. Smith testified to McKay's botanical proficiency when in ENGLISH вотANY, in the article on Eriophorum alpinum, he wrote: 'We are obliged for wild specimens 
(they say) to Mr John McKay of Edinburgh, a most diligent and skilful investigator of the vegetable kingdom, by whose communications we have often been enriched'-enriched, in fact, to the extent that McKay is acknowledged as the contributor of over 50 British plants to the pages of ENGLISH BOTANY.

When Robert Menzies died McKay's well known qualifications recommended him to Rutherford who offered him the post of Principal Gardener in the Botanic Garden. McKay, believing the post to be an 'eligible one' and hoping that it would 'turn out to my liking', accepted the offer and in February I 800 took up his residence in one of the cottages in the Garden. He at once brought his varied experience to bear on this new sphere of work and effected many improvements, to Rutherford's great satisfaction. Within the first month he had removed several old trees and was busy exchanging plants with Sir Joseph Banks at Kew. Field botany once again began to prosper in the Botanic Garden for in the summer of I800 and I80I, during Rutherford's lectures, McKay led some of the more earnest students on botanical excursions in the neighbourhood of Edinburgh and to districts with which he had been familiar since his boyhood.

Shortly after his appointment to the Botanic Garden McKay wrote to Robert Brown, recently appointed naturalist to Flinder's Expedition (I80I-05): 'In my present position I feel myself interested in everything relating to Botany, and more stimulus than formerly. The Edin. B. Garden you know has been much neglected, but every endeavour will now be exerted to raise it to that pitch of Eminence it ought to hold among the British Gardens.' There is little doubt that McKay would have been successful in his endeavours had he not died in 1802 .

Thus fell, in the prime of life, a young man who bid fair, had he lived, to have reached the very summit of eminence in his profession. He possessed an acute and penetrating genius, a good taste, and a thirst for the knowledge of nature, that led him to pursue his studies with the greatest eagerness and ardour. He discharged his professional duties with unremitting assiduity; and often did he rob himself of his nightly rest in acknowledging the communications of his numerous botanical correspondents.

This was written of him by his friend Patrick Neill. ${ }^{2}$ And the EDINBURGH COURANT, on 22nd April I802, had this to say:

I Letter of McKay to Lt. Col. Brodie of Brodie House, Forfar.

2 SCOTS MAGAZINE (I804). 
'His manners were gentle, his disposition obliging, his zeal for knowledge great, and his skill in botany uncommon. It would be difficult to say whether he was more amiable as a man, or more excellent as a botanist.'

Certain it is that, by his death, Scotland lost a field-botanist who might well have dealt with its flora in the same comprehensive and thorough fashion in which the brother, James Townsend McKay, treated that of Ireland.

For the third time Rutherford had to appoint a Principal Gardener and his choice ultimately fell on McKay's colleague and fellow explorer of the Scottish countryside, George Don. I Possibly Rutherford sought the opinion of others, for both James Edward Smith and Brodie of Brodie, apparently quite independently of each other, recommended Don for the vacant post, Brodie writing to Smith on 24th October I802: 'I have got your correspondent, Don, the Botanic Gardens at Edinburgh. There he will do well and be of great service to Dr Rutherford and the public.'2 Possibly, too, Rutherford took some time to convince himself that Don was the right man for the post, for, although McKay died in April I802, Don did not take up his dutics at the Garden until the December of the year.

Rutherford would have had the opportunity of making Don's acquaintance when the latter visited McKay at the Garden, and, though he could not fail to have been impressed by Don's great knowledge of British plants and of some aspects of gardening, he may have had reservations about his temperamental suitability for the post of Principal Gardener. Bayley Balfour admirably argues out the position thus:

In the light of after history may we not construct a picture of, on one side, Rutherford, tempted by Don's qualifications as a botanist and gardener, yet hesitating to appoint one whose independence and wilfulness, showing, as one must believe, in Don's every feature and action, gave scarce promise of contentment under control; and, on the other side, Don, wrestling with himself over the value of his freedom and doubtful of the wisdom of entangling himself in the trammels of the routine of a subordinate and ill-paid official post which would enforce banishment from the open-air life amongst the plants on the hills to which he had become used. Whether this

\footnotetext{
${ }^{1}$ Don wrote to N. J. Winch, from Forfar, on IIth May I 802: 'In calling back to my mind that worthy man [John McKay] excites painfull sensations in my breast and wounds my feelings deeply.'

2 Smith correspondence, Linnean Society.
} 
be right or wrong, certain it is that Don's advent as Principal Gardener was long delayed, and it is significant that when he did come to Edinburgh he did not give up his Forfar Garden. ${ }^{\mathrm{I}}$

In fact he left the Forfar garden in the care of his father who was a currier who had moved to Forfar, about 1772, from the parish of Menmuir where George Don had been born in I764. Though the true facts of his early life are by no means clear he seems to have received an ordinary elementary education at the parish school and to have early showed his taste for natural history by exploring the countryside in search of birds, insects and plants. After having been apprenticed to a clock maker in Dunblane, where he made his first herbarium collections of flowering plants and mosses, he became a gardener at Dupplin and used all his leisure time exploring the Ochils and the spurs of the Grampians. In this fashion he increased his knowledge of the Scottish flora. From Dupplin Gardens he moved to England and occupied various gardening posts in Worcestershire, London, Yorkshire; wherever he went he searched for the native plants and invariably was able to record some for the first time. And finally he returned to Forfar, leasing, in I797, for a term of 99 years, two acres of land known as Dovehillock which sloped to the west into what at one time had been Forfar Loch. He made a large artificial pond which he stocked with aquatic plants and fish and in a broad border he arranged the native plants he had assembled according to the Linnaean system. In addition he rented several acres of land as a nursery for young trees.

Here he lived frugally and penuriously, absenting himself from home often for weeks at a time, his plaid and a bag of oatmeal or some bread and cheese sufficing for shelter and sustenance, whilst he explored the beautiful district of Clova and other parts of the Highlands. And here he was once visited by Dr Patrick Neill who tells of the circumstances: ${ }^{2}$

When on a pedestrian excursion along the east coast of Scotland I happened to spend a night at Montrose, and it occurred to me that both Brechin and Forfar deserved to be visited-the former for its well-known Den Noran and its round tower of remote antiquity; the latter for its remarkable botanic garden, and its owner, whose fame was familiar to me, owing to my intimacy with his regular correspondent, Mr John McKay of the Leith Walk Nurseries. ${ }^{3}$ In passing along the margin of the sea basin above Montrose,

\footnotetext{
I NOTES ROY. BOT. GARD. EDINB., III (1904), p.5O.

2 TRANS. BOT. SOC. EDINB., IV (1850-53), p.II7.

3 The Nurseries of Messrs Dickson.
} 
the tide being at ebb, I picked up some fine plants of Salicornia lierbacea, then in flower, and also a somewhat shrubby variety. On reaching Forfar towards evening I soon found Don's garden, and entering inquired of a very rough looking person with a spade in his hand, whom I took for a workman, whether Mr Don was at home. The answer was, "Why, sir, I am all that you will get for him'. Having apologised in the best way I could, I stated that when I left home I did not anticipate a visit to Forfar, else I could have brought a note of introduction from Mr John McKay. Mr Don, pointing to my botanical box, immediately said, 'That is introduction enough for me'; and, having inspected the contents, remarked that he was in want of an example of Monandria monogynia, an Equisettm not having succeeded, and forthwith conducted me to the Linnaean arrangement. I was then introduced to Caroline, his wife, who had brought him two sons and a daughter. I persuaded him to accompany me to the inn at Forfar, where he spent the evening with me. Next morning at six he met me there by appointment, and conducted me to Restennet Moss, where I had the great satisfaction of procuring a living patch of Eriophorum alpinum and a number of fine specimens for drying. The Moss was at this time partially drained for the sake of a rich deposit of marl, but at one end there was still sufficient marsh for the growth of Schoenus (Cladium) Mariscus and Eriophorum angustifolium, and, of course, for the rare E. alpinum, which grew on the drier or firmer parts of the Moss. $\mathrm{Mr}$ Don remarked that in a few years the plant would disappear, which I understand has accordingly happened.

\section{Dr Neill describes Don's garden in THE scots MAGAZINE} for June I 809 :

The existence of a flower garden and flower nurseries at Forfar, which for number, diversity, and rarity of the hardy plants cultivated in it are perhaps scarcely to be surpassed in Britain, is a fact not generally known. We think it right to give it what publicity is in our power, both as a piece of interesting information to botanical amateurs, and of justice to the indefatigable exertions of $\mathrm{Mr}$ George Don, who, we understand, has surmounted many difficulties in following out his favourite pursuit, and in forming so extensive and curious a collection of living plants. The whole of the plants are of a hardy sort, $\mathrm{Mr}$ Don not possessing either green-house or stove for the protection of such as are tender. It is in alpine plants and in hardy perennials, and aniuals, that the Forfar garden excels. The garden is situated on a bank which slopes down to the lake of Forfar, not far from the town; and it fortunately includes a great variety of soils, from dry to peat bog. No place could be found more favourable for alpines and aquatics, which are in general found to be of rather difficult cultivation, but which flourish here as in their native habitats .... To give some idea of the extent of the collection, I shall mention the number of species of several genera which are at present growing in the garden. Of the genus Veronica, there are 55 species, of Salvia 50 species, Cantpanila 44, Allium 40, Saxifraga 46-some of the rarest ones, as S. caesia, S. petraea, S. rivularis, etc.; Dianthits about 20 species, Cucubalus I3-being the whole ever cultivated in Britain; Silene nearly so, Fumaria I4, the genera 
Ononis, Lathyrus, Vicia almost complete, Astragalus 40 species, Trifolium, no fewer than 69, Hieracium 44. It were needless to enumerate more. The botanist will form a due estimate of this collection on being told that he may see here upwards of 60 species of Carex, flourishing in great perfection. The agriculturist may here find the whole of the hardy Gramina, carefully distinguished and arranged, amounting to over roo kinds. This season Mr Don has introduced several hundred species of hardy plants, most of which we are told have never before been cultivated in Scotland. Among the rare British plants at present in flower in this garden may be mentioned the elegant little grass called Knappia agrostidea (Agrostis minina of Smith) and the Holosteum umbellatum. Among the hardy exotics now in flower, the Panax quinquefolia (the root of which constitutes the famous panacea of China called ginseng) is most remarkable. There are certainly very few living specimens of the plant in Scotland; and we have not before heard of its flowering in this country. The Dalebarda fragarioides, brought from North America to France by Michaux and only lately imported into Britain, has already found its way into Mr Don's collection. It is entirely a new plant, belonging to the Icosandria Polygynia, and naturally allied to the Geums.

The Forfar garden, it must, however, in conclusion, be confessed, makes very little external show, being in a great measure destitute of the ornament which arises from neat alleys with hedges or edgings, or well laid-out or well-kept gravel walks. It is, in fact, merely an uncommonly excellent collection of hardy plants; and while it would doubtless fail to please the lover of tasteful gardening, it would as certainly prove highly interesting to the botanist and to the curious cultivator. Mr Don, we have been told, has an ample nursery of rare hardy plants, for which he receives orders from the curious in different parts of Britain; and, when the proceeds of these shall enable him, we understand it to be his intention to improve the exterior appearance of his garden.

Such, then, was the man who succeeded his friend McKay to the charge of the Botanic Garden in Edinburgh. Of the changes he made in the Garden nothing is known. But it is known that he maintained his overwhelming passion for exploring the Scottish countryside through which he no doubt stimulated some of Rutherford's students to do likewise. He was in frequent correspondence with the best botanists in Scotland and England, notably with J. E. Smith who probably was instrumental in Don's election as an Associate to the Linnean Society in 1803 . The following year he began to publish his HERBARIUM BRITANNICUM which he dedicated to Sir Joseph Banks. Four fasciculi, each of twenty-five plants and containing a due proportion of rare alpines, were to be issued yearly. In the preface he says:

Since he began his botanical excursions into the Highlands of Scotland, in the year I779, he is confident (and he hopes he may mention it without the 
imputation of vanity) that he has traversed more of the Caledonian alps than any other botanist has ever done. He has repeatedly ranged over the great mountains of Angusshire which surround the great district of Clova, where no one on a similar pursuit has ever preceded him. He has also searched the vast range of mountains which stretch about sixty miles through the district of Knoydart, in Inverness-shire, a region which had never before, nor has since, been examined with a botanical eye. $\mathrm{He}$ is the only botanist, too, who has explored the lofty mountains of Cairngorm and the great hills of the neighbourhood.

Thus it was to be for the rest of his life and many are the rare plants he discovered. During his frequent visits to Ben Lawers he collected that rare Sandwort Minuartia rubella, the beautiful forgetme-not Myosotis alpestris, and a sedge Carex atrofusca-all new to the British flora-the rare mountain fern Woodsia alpina and the three rushes Juncus biglumis, J. bulbosus and J. castaneus. For the first time in Scotland he located Bartsia alpina and also saw the Alpine Sandwort Sagina saginoides, on Meall Ghaordie. Carex vaginata was his outstanding find on Cairngorm, and the Curved Woodrush Luzula arcuata on the great bulk of Ben Macdhui. As he says, time and time again he explored Clova and was the first to make known to botanists this beautiful district of Angus. Here he discovered Carex rariflora, new to science, Hieracium lingulatum and the Yellow Oxytropis Oxytropis campestris, and on Little Culrannoch, Lychnis viscaria the Red German Catchfly. On distant Ben Nevis he gathered the alpine form of Sagina maritima and the rare grass Poa flexuosa; on Ben Lomond in 1789 he saw Carex saxatilis the Russet Sedge, and the Alpine Mouse-ear Chickweed Cerastium alpinum; a form of the latter from Ben Chonzie he misidentified as Cerastium latifolium; Ben Voirlich yielded the Purple Saxifrage Saxifraga oppositifolia, and Schiehallion the Bladder Sedge Carex vesicaria and the Alpine Meadow Rue Thalictrum alpinum. His many ascents of Lochnagar revealed the riches of the alpine flora of this grand mountain. Here he found the Alpine Foxtail grass Alopecurus alpinus-a species new to science-as well as such rarities as Cochlearia alpina, Saxifraga rivularis, the Blue Sow-thistle Cicerbita (Sonchus) alpina, and the grasses Deschampsia alpina and Poa $\mathrm{x}$ jemtlandica.

Fasciculi of the HERBARIUM BRITANNICUM continued to appear until I8I2, the year in which Don's most important paper was published-An Account of the Native Plants in the County of Forfar, and the Animals to be found there. This formed an appendix to the GENERAL VIEW OF THE COUNTY OF ANGUS OR FORFAR 
and in its forty-nine pages Don enumerates 90 species of flowering plants, roo mosses and I 20 lichens from Clova. Altogether nearly 300 "larger plants, are listed, and most of these, he says, could be seen growing in his Forfar garden.

It is unlikely that the Botanic Garden in Edinburgh prospered under Don's brief regime. He was too interested in his native plants, too often away from the Garden hunting for them, to have an inclination for the cultivation of a wide range of garden plants, especially stove plants of which he had no experience. Moreover, he often forsook the Garden to attend the medical classes in the University with the view ultimately of taking up this profession. Clearly the comparative seclusion of a Botanic Garden was no place for one of Don's disposition and, not surprisingly, he resigned from his post-and returned to Forfar-probably in I806, unofficially practising medicine in his retirement.

Thomas Sommerville, who in all probability had been trained in, and was employed at, the Botanic Garden, succeeded Don. Like that of his two predecessors his reign was a brief one for he died in March I8IO at the age of 27. Had he lived to a riper age there is some evidence that he would have developed the Garden considerably for in 1809 a contributor with the pseudonym 'Qoth Timon' (it may have been Patrick Neill), in an article Some Suggestions for the Improvement of the Edinburgh Botanic Garden, wrote: ${ }^{1}$

Here we shall, in the first place, express the satisfaction we derive from the admirable style in which the Botanic Garden is at present kept, at least in so far as depends on the Superintendent. ${ }^{2}$ We have long been familiar with this Garden; but at no period in our observation can we discover a more judicious plan to have been pursued in the management of the various plants (which indeed their health so strongly indicates), or better taste in the general system. In gardening, every likely exhibition of what is beautiful in nature has a fine effect; winding walks, where the line of beauty is observed, are peculiarly pleasing; at every turn we experience increased pleasure, from the combined beauties of art and nature; and in this particular we remark the walks lately laid out in this Garden, which certainly do honour to the good taste of the projector.

The state of the glasshouses did credit to no one, however, for a writer in the scots MAGAZINE for I808 could not help

I SCOTS MAGAZINE, LXXI (I809).

2 Thomas Sommerville. 
.... taking notice of the deplorable consequences that have resulted from one of the hot-houses having last summer fallen in ruins, and not being renewed owing to want of funds. In this hot-house was contained a very fine old plant of Ficus stipulata [Ficus pumila], or Trailing Fig-tree, which had been placed here nearly thirty years ago, or soon after the introduction of the species from China, and which now covered the whole back-wall of the house, so that it was perhaps the largest and best specimen of the plant in Britain. This plant, not being capable of removal, necessarily became exposed to the open air; and, as might have been expected, it has proved unable to withstand the rigorous cold of a Scottish winter, and has now (March 1808) irretrievably perished. Surely the wants of this Royal Garden must not be fully known to Government, else a pittance would be spared, even in these times of unexampled difficulty, to preserve alive the few valuable full-grown exotics which it contains. A very fine Camphor-tree .... was lately cut over, chiefly in order to avoid the expense of raising the roof of the shed in which it is contained; and as this shed is also becoming ruinous, the specimen is likely to be lost by exposure to the cold. That such things should happen in a National Garden, solely owing to want of pecuniary aid (for the Garden is otherwise kept in most excellent order), is certainly little else than a national disgrace.

Unfortunately, in March I8Io, in the same magazine, ${ }^{\mathrm{I}}$ in a short note about the Botanic Garden, Dr Neill had to write:

This unfortunate Garden, on the neglected state of which we have, for the last two years, been occasionally commenting, has sustained an additional misfortune in the loss of its Superintendent, $\mathrm{Mr}$ Thomas Sommerville. This promising young man, after having lingered for many months in a gradual decline, died on the 17 th instant, at the early age of 27 . He possessed very considerable abilities, both as a professional gardener and a botanist; and had he lived, would doubtless have distinguished himself in this latter respect.

For the fifth time therefore Professor Rutherford was called upon to appoint a Principal Gardener.

I SCOTS MAGAZINE, LXXII (I8Io), p.I66. 


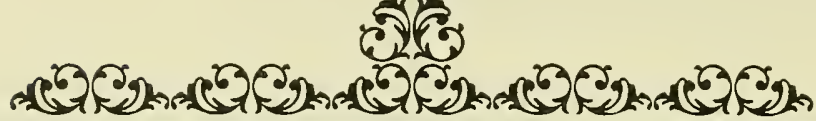

\section{CHAPTER EIGHT}

\section{William McNab}

IN SEARCH OF A NEW PRINCIPAL GARDENER TO BE IN OFFICE in time for the approaching summer session of the University Rutherford wrote to the most influential man in British botanical circles, Sir Joseph Banks, President of the Royal Society and Director of the Botanic Gardens at Kew.

Edin. I9 March I8Io

Sir,

I trust you will pardon the liberty I take of applying to you in the present occasion, as I know no one who is so capable of giving me advice and assistance as you are. I must take the liberty of acquainting you that Mr Sommerville, who was gardener of the Botanic Gardens in this place, is just dead, and I am in the greatest anxiety to fill up the place properly, and indeed as soon as possible, since the season of the year is now so far advanced. Unfortunately the workmen now in the garden are in a manner entirely strangers to me, having come into it only a week or two ago, and I am thus more embarrassed than I should otherwise be. Such being the case, I should esteem it as a singular obligation if you could recommend any person that you think might be qualified for the office. I need say nothing of the talents required, you are a perfect judge of this subject. The Emoluments are $f_{40}$ a year salary and whatever gratuities may be given by people who visit the garden, besides I allow him $2 / 6$ from each of the students. Should you recollect any fit person who might incline to enter in this employment, I shall esteem it as a particular favour if you take the trouble to mention him to me. I hope you will excuse the liberty I have taken. I have the honour to be with the greatest respect, $\mathrm{Sir}$,

Your most obed. and most humble Servant,

(Sgd.) D. Rutherford.

Sir Joseph Banks passed on Rutherford's request to William Townsend Aiton, the Principal Gardener at Kew, writing to him on 22nd March: 
My dear Sir,-I send the enclosed to you as a matter of course, if it should be the means of providing for any one of your worthy lads it would be a great satisfaction to me but I fear the salary is much too small unless the Emoluments make a much greater addition to it than can be expected.

Always Yours,

Jos. Banks.

Banks was not alone in thinking the salary much too small. No doubt Dr Patrick Neill was expressing the general feeling when referring to the matter in his SCOTS MAGAZINE article of I8IO:

While the situation of superintendent is thus vacant, it can give no offence, we should suppose, if we remark upon the insufficiency of the salary. Forty years ago, the keeper of the Botanic Garden may have found himself 'passing rich with forty pounds a year'. But that such a pittance must now be utterly inadequate is too evident to require illustration. In this country there is little difficulty in funding men of merit in the gardening profession; indeed Scottish gardeners are held in repute all over the empire. Several excellent cultivators and keen botanists have, during the last ten years, issued from the Edinburgh Botanic Garden itself. To become Superintendent of the Physic Garden of Scotland is justly accounted a horticultural and botanical honour. But it is hard to ask a person to leave a situation where he receives from $f^{60}$ to $\mathcal{E}_{\mathrm{i}} \mathrm{oo}$, and to offer him $\mathrm{f}_{40}$ a year. The 'feather in his cap' will not, in these times, make up for the deficiency. The perquisites of the place are very trifling and uncertain, and we understand, cannot be reckoned worth more than fio a year.

\section{On 26th March, Banks replied to Rutherford's letter:}

My Dear Sir,--The high respect I feel for the Botanic Institution at Edinburgh and the personal regard I have for the worthy Professor have made me anxious to fulfil the commission contained in your last favour. I therefore applied without delay to Mr Aiton whose foreman I knew to be particularly qualified to fill the office now vacant in your garden, being a man eminently skilled in the names of plants, as well as in their culture, modest, unassuming, quiet, civil and obedient. As he has been Io years at Kew Mr Aiton is desirous of providing for him and will therefore readily part with him if he thinks the offer likely to produce and secure a comfortable settlement for life. Of this however $\mathrm{McNab}$ the foreman has some doubts, and in truth as the price of every necessary of life has of late increased materially and still contintes to increase, or rather as the value of money diminishes every day his doubts are not without a rational foundation.

I have however brought him to say that if $f_{\text {so }}$ a year can be added to the salary of $f_{40}$ he will thankfully accept the place.

Whether this is feasible or not I cannot at all judge. I can only say that as it seems necessary that all fixed salaries should keep pace in their advancement with the admitted depreciation of money, the present is a very proper time to make an addition, and this as I do not know that there is in England 
so proper a man for the present vacancy as $\mathrm{McNab}$ is. He has all the knowledge both of botanical nomenclature and of Horticulture that Don[n] now gardener of Cambridge possesses-I think in a better style, and he is more modest and unassuming by far.

If it is not practicable to obtain an increase of salary I shall still do my endeavour to persuade him to accept the place as I think he may be confident that an addition must soon be made, if it cannot be done at this time.

Your very faithful and very humble Ser. I am My Dear Sir,

(Sgd.) Jos. Banks.

Rutherford, no doubt aware of Neill's criticisms in the scots MAGAZINE, answered Sir Joseph Banks thus:

Dear Sir,-I had the honour to receive your very kind letter two days ago, and I beg leave to offer my most earnest thanks for the trouble you have so readily taken, in procuring a gardener for the Botanic Garden. The salary of $£ 40$ which I mentioned, was what I had been in use of allowing. Surely I can have no objection to raising it to $\mathcal{E}_{50}$ or some shillings below $f_{5}$ just to avoid the Tax. Indeed I had determined to do so as soon as I was assured of an additional allowance for the maintenance of the Garden, which I believe is already granted. I hope then that $\mathrm{Mr} \mathrm{McNab}$ will have no objection to the Place; everything that depends on myself shall be done to render his situation comfortable and agreeable, only one article I should wish him to understand that nothing whatever is to be sold or given from the Garden unless with my permission. Indeed I have had occasion to remark such depredations, unfortunately not however just at the time things were removed, as can hardly be repaired. You may believe that I am anxious that he could be with me as soon as possible and I should be extremely obliged to you if you convey him such intelligence. Indeed I should like to hear from him as there are some plants which I wish him to provide for me before he leaves London. I am quite ashamed to use such freedom with you, but I sincerely hope you will pardon me when you consider the anxiety I have to fix a proper person in the Garden.

I have the honour to be with highest respect and esteem

Dear Sir,

Your most obedient and most humble Servt.

D. Rutherford.

Fortunately for the Edinburgh Botanic Garden, the post thus offered to William McNab held sufficient attractions to induce him to resign from the one at Kew which carried a salary of a hundred guineas. He took up his duties in May I81o and a new era in the history of the Garden began.

IJames Donn, a protegé of Aiton and at that time Curator of the Botanic Garden Cambridge. 
William McNab (Plate va) was born one of a family of twelve on I2th August I780 at Knockcairsh, in the parish of Dailly in Ayrshire, where his father, James $\mathrm{McNab}$, was a farmer. At the age of sixteen his gardening career began when he was apprenticed in the garden of Mr Kennedy of Dunure, at Dalquharran in Carrick. There he remained for three years before moving to the gardens of the Earl of Haddington at Tyninghame in East Lothian. Fourteen months later he made the important move to London with a recommendation to William Aiton at Kew where he became employed in March I80I. Clearly he must have impressed Aiton as a gardener, for when William Kerr, a foreman at Kew, was sent to Canton in I803 to collect plants, McNab was appointed in his place. This position he held until r8ro when he decided to return to Scotland.

$\mathrm{McNab}$ threw himself into the task of developing the Botanic Garden with immense enthusiasm and success, as Dr Neill narrates. 'Through the kindness of his botanical friends in the south, he has already introduced into the Edinburgh Garden many of the new and rare species of stove and greenhouse plants, which were never before cultivated here. Among these are a number of New Holland plants, particularly six species of Banksia, and two of the rarest of the Mimosa tribe.'I 'Mr McNab from Kew is doing wonders at our Botanic Garden here, if there were but funds for improvements." "The personal exertions of the superintendent, or head gardener, $\mathrm{Mr} \mathrm{McNab}$, we believe to be unremitting; and it seems a public disgrace that they should not be better rewarded, and that his abilities and zeal should not be seconded by a small grant of the public money for the improvement of the garden. Notwithstanding this discouraging state of matters, $\mathrm{Mr} \mathrm{McNab}$ has lately introduced many new or very rare plants into the garden. He has, in particular, carried the culture of exotic aquatics to a pitch hitherto unknown in Scotland.' ${ }^{3}$ And in Patrick Neill's I8I2 essay on Scottish Gardens and Orchards, he tells us that 'At present the Garden enjoys a most active and intelligent superintendent, Mr William McNab, who, notwithstanding the discouraging circumstance of the funds for maintaining the Garden being extremely inadequate, has contrived not only to keep up but to increase the collection of plants.'

I SCOTS MAGAZINE, LXXII (I8IO), p.367.

2 Patrick Neill to Sir J. E. Smith, Is Feb. I8II-Smith Corresp., Linn. Soc.

3 SCOTS MAGAZINE, LXXIV (I8I2), p.484. 
Patrick Neill's essay of I8I2 was contained in Sir John Sinclair's GENERAL REPORT OF THE AGRICULTURAL STATE AND POLITICAL CIRCUMSTANCES OF SCOTLAND and describes the Botanic Garden at this time. There was, of course, much that had survived from Professor Hope's day, including his monument to Linnaeus. Several of the stakes of the Huntingdon willow which Hope had originally used to mark out the area of the Garden had sent forth shoots and by I8I2 formed lofty trees at the corners and sides of the Garden. There were excellent specimens of the Canadian and Carolina poplars, the Chinese Arbor-vitae Thuja orientalis, the Strawberry tree Arbutus andrachne, the Carolina All-spice Calycanthus floridus, the Central and Southern European Prunus mahaleb. Unfortunately one of the plants in which Hope had been deeply interested had died in I8II-Ferula asafoetida. It had been grown in the open ground since Hope's time, sheltered by a yew hedge and covered every winter with sawdust or litter. In the dry stove Hope had planted a specimen of the Canary Island Dragon's Blood tree Dracaena draco which was now $30 \mathrm{ft}$ high with a stem two feet six inches in circumference and which was the finest specimen of its kind in Britain; its top, with its crown of long narrow leaves, was ready to burst through the roof of the house. There was a small house occupied solely by a plant of the Camphor tree Cinnamomum camphora; there were large specimens of the Date Paln and of Cycas circinalis the Sago Palm. There was a collection of hardy aquatic plants in a circular pond in front of the conservatory, a grouping of medicinal plants, and an arrangement of hardy herbaceous plants.

In the two years following his appointment $\mathrm{McNab}$ had increased the collection enormously. For the first time the Egyptian Paper Reed or the Papyrus of the ancients Cyperus papyrus, was being grown, as were five species of the Australian Banksia, the Javanese Magnolia coco, the close ally of the Pancratium-Eurycles sylvestris from Amboina, a relative of the barberry-the monotypic Nandina domestica of China, and the plant which commemorates the name of Captain Bligh, Blighia sapinda the Akee tree of Guinea. The cultivation of tender aquatics was scarcely known in Scotland until $\mathrm{McNab}$ put it into practice. By I8I2 the flowers of several water lilies could be seen for the first time in Scotland, including the white or rose tinted ones of the Egyptian Lotus Nymphaea lotus, the deep red of N. rubra of Bengal, and the pale blue of N. stellata of S. and E. Asia. From the Eastern United States the yellow flowered Nuphar 
microphylla had been introduced, whilst the two aquatics which probably caused most interest were the East Indian Lotus, Nelumbo nucifera and the annual plant with leaves second only in size to Victoria, Euryale ferox.

A legacy from the days of Hope was a collection of nearly I7O medicinal plants not a quarter of which at that time found a place in the Pharmacopaeia of the Edinburgh College, as well as nearly I,250 hardy herbaceous plants arranged according to the system of Linnaeus. McNab had established a further collection of herbaceous plants, over 2,000 in all, which he had arranged according to the system of de Jussieu-the first such arrangement in Scotland. According to Neill, the collection contained over 4,000 species belonging to at least I,000 different genera. He writes:

It has been already hinted, that the funds for the maintenance of the garden are insufficient. They have not been increased in any due ratio with the depreciation of money; and nothing can be more evident than that the sum (it is believed $£_{1} 170$ a year) which was perhaps found barely adequate forty years ago, must now be utterly insufficient. The salary of the Superintendent, it is said, still remains stationary at $\mathcal{f}_{40}$ a year $\mathrm{I}$-originally a very moderate allowance, now become a pittance which it is disgraceful to the nation to offer to the Superintendent of this Royal Garden, especially when he happens, as at present, to be a man of uncommon merit in his profession. Some small occasional sums have, it is believed, been granted by the Barons of Exchequer in Scotland, in aid of the garden; but an increased permanent yearly income is not only indispensable, but a considerable grant is needed, for rebuilding the hot-houses, which are verging on ruin; one of them indeed having already tumbled down. ${ }^{2}$

As with his predecessors, Rutherford expected his Principal Gardener to have a working knowledge of the Scottish flora, for, among the specimens which the Professor used for the instruction of the students at the Garden a proportion of them were the wild plants of the neighbourhood. Moreover the Principal Gardener was expected to accompany the students on their botanical excursions and to help them to name the plants they collected. In the course of the years McNab became as knowledgeable about the Scottish flora as his predecessors had been.

The desire for knowledge of the local flora was not confined to the University students and the Principal Gardener. In April I8I5 about twenty of the journeymen gardeners from the Botanic Garden and from Walter Dickson's Leith Walk Nursery formed

I This is a mistake.

2 SCOTTISH GARDENS AND ORCHARDS, (I8I2), p.IO3. 
themselves into a society for mutual instruction in matters relating to their profession. They called their society the Leith Walk Linnean Society. ${ }^{\mathrm{I}}$ As the unsettled nature of their employment prevented their entering into a permanent scheme they resolved, as an experiment, to devote the summer months to practical botany, and, as a preliminary step, to set about acquiring an accurate knowledge of the plants indigenous to the neighbourhood of Edinburgh. They hired a schoolroom for their Monday evening meetings and each paid sixpence per week from which were purchased elementary books suited to the subject then under discussion. Willdenow's elements of botany, Smith's introDUCTION to bOtANY, Hull's British FLORA, Martin's LANGUAGe of botany, and W. T. Aiton's epitome of the HORTUS KEWEnSis, were soon procured. The Society's President, John Bain Mackay, then aged twenty, allowed the Society the use of his copy of Lightfoot's FLORA SCOTICA. Each week two members were appointed to collect all the indigenous plants they found in flower. These were passed to the Secretary for naming before being put before the weekly meeting when they were examined by the members present. In this way did the members become practically acquainted with the native plants and their habitats and indoctrinated into classification and terminology. In the autumn of I8Is a number of the members left Edinburgh for situations elsewhere but those who remained carried on the Society's activities in the spring of I8I6. For how many years the Society functioned is not known, though it is unlikely to have been in existence when the Garden moved from Leith Walk in 1820.

Whilst $\mathrm{McNab}$ was gradually increasing the prestige of the Botanic Garden and increasing his own knowledge of the Scottish flora, Rutherford was busy teaching his students in the summertime, undertaking clinical teaching in the Hospital, maintaining his private practice and showing a keen interest in the active literary world of the day in which his nephew (Sir) Walter Scott was the most conspicuous figure. And, before he died on Isth December I8I9, he was able to secure a fio rise in salary for his Principal Gardener. But even on this salary $\mathrm{McNab}$ was in poor financial circumstances; so much so that within a month of Rutherford dying and before his successor was appointed, he was obliged to present the following memorial which throws interesting light on McNab's life at that time.

I GARDENER'S MAGAZINE, III (I828), p.47I-2. 
Unto the Right Honourable the Lord Chief Baron and Barons of Exchequer.

The

MEMORIAL OF WILLIAM MCNAB

Curator of the

ROYAL BOTANIC GARDEN, EDINBURGH

\section{Humbly sheweth}

That the Memorialist before he came to his present situation was Foreman at the Royal Botanic Garden at Kew a situation of very great trust and which the

- Memorialist was so fortunate as to fill for eight years to the entire satisfaction of his superior Mr. Aiton head gardener, whose abilities and knowledge are well known, and who is entrusted not only with the gardens at Kew which are reckoned to contain the finest collection of Plants in Europe, but also with the superintendence of those at Kensington and some other of the Royal residences.

The Memorialist during the last five years he was at Kew had a salary of one hundred guineas per annum and a House firing and candles, and the use of an excellent Botanical Library with some other advantages, and as he was so fortunate as to possess the good opinion of Sir Joseph Banks and some other distinguished Botanists he was entitled to expect when he left the Royal Gardens a more advantageous situation.

In 18 Io the late Dr Rutherford applied to Sir Joseph Banks to recommend a proper person to take charge of the Royal Botanic Garden at Edinburgh and in consequence of his recommendation the Memorialist was desired to become Curator of that garden and the Memorialist understood that some arrangements were likely to be made relative to the garden which would make it a desirable situation.

The Memorialist with this view came to the Edinburgh Botanic Garden for a salary of fifty pounds per annum with House fire and candle and two shillings and sixpence from each Botanical student, which on an average comes to from EI4- EIs per annum.

The Memorialist has no ground or vegetables for his family use.

The Memorialist continued nine years at the above salary and last year he had an addition of ten pounds in consequence of a promise made to him by the late Professor and it may be mentioned that the Memorialist has had much more work personally to perform here that he had reason to expect on account of the small number of workmen cmployed. He has had to work hard with his own hands in order to keep the garden and the collection of plants in a respectable state in doing which being frequently exposed to sudden heats and colds in the Hot-houses he has materially suffered in health.

The Memorialist is also exposed to much unavoidable expence solely for the benefit of the garden and for which he has at present no means of being reimbursed, in entertaining in his own House various correspondents in the line of professional gardeners and those in similar situations and circumstances in life with himself who visit the garden and from whom the 
Memorialist receives important plants and seeds for the use of the garden and to whom some attention is therefore due. Altho this is done in the most economical manner yet it is very severely felt by the Memorialist. He would not be exposed to this expence were it not with the view of getting additions of plants and seeds for the garden, which the Memorialist can shew have been very considerable within these later years as well from the Books which he keeps in the garden for registering the plants and seeds which are received, as from the plants themselves which are now growing in the garden.

The Memorialist is also at considerable expence for Botanical Books which cannot be wanted in an establishment like this. These the Memorialist has to purchase at his own expence while in most similar situations which the Memorialist has visited a small Botanical Library is kept at the expence of the Establishment and where the Curator has no occasion himself to purchase botanical Books. In Oxford and Liverpool this is the case.

The Memorialist has a large family to provide for and he finds that on his present income he cannot give his children the education which his situation in life would seem to demand.

The Memorialist has no means of knowing the salary and other advantages which other Botanic Gardeners may have in various parts of the Kingdon. He knows however that the Curator of the Botanic Gardens at Liverpool has 175 guineas per annum as salary with house firing and other advantages.

The Curator of the Botanic Gardens at Glasgow has $f, 90$ per annum with a promise of an advance a house and a piece of ground for growing vegetables for his family and five shillings from each student who may attend the Botanical Class.

The Memorialist understands that the Curators both of the College Botanic Garden and of the Glasnevin Botanic Garden at Dublin have upwards of Eiso per annum.

On these grounds the Memorialist earnestly entreats that the Right Honourable the Lord Chief Baron and Barons of Exchequer will take his case into consideration. He relinquished a situation in which he had roo guineas per annum when he accepted that of Curator of the Botanic Garden. It is both more laborious and more expensive and he has never drawn above f80 per annum, many years less. He therefore trusts that he will receive such an increase of permanent income as shall be thought reasonable in the circumstances of the case.

Wrlutam McNab, Royal Botanic Garden, Edimburgh. I3th January, I 820.

The memorial was endorsed by Sir Joseph Banks, Mr William Aiton of Kew, and supported by Mr Kennedy of Dunure, in whose garden $\mathrm{McNab}$ had been apprenticed. Two months later, on I4th March, Rutherford's successor, Professor Graham, added his support. The response was favourable. In I $820 \mathrm{McNab}$ 's salary was raised to $£ 80$ and, two years later, to $f_{1} \mathrm{roo}$. Not for another fourteen years was a further advance given to him and then, in I834, his salary was raised to fiso. 
Just as this Kew trained gardener was to spend his life building up the fortunes of the Edinburgh Garden, so an Edinburgh trained gardener was to spend his life in the service of Kew. John Smith was born in Aberdour, Fife, in 1798, and received the usual education then taught in the parish schools in Scotland, at Pittenweem. He then followed his father's occupation as a gardener, entering the garden of the Earl of Moray at Donibristle, near Aberdour, as journeyman, in I8I6. The following year he became journeyman at the garden at Caley House, Kirkcudbrightshireand walked the ros miles from Edinburgh to Caley House, in three days. Finally, through his father's influence with Wm. McNab, he returned to Edinburgh in I8I8, as journeyman in the Royal Botanic Garden.

Here I met with minds congenial with my own, and although four of us lived in a back shed one-roomed bothy, all personal discomforts were forgotten, our leisure time being entirely employed with books, and in drying specimens of plants. Having the privilege of attending the botanical lectures, from which I first gained a knowledge of the natural system of botany, and Mr McNab having kindly lent me Jussieu's NAT URAL SYSTEM, from which I copied the system of arrangement and the chief characters and the orders belonging to each. These circumstances, together with the examples of many exotic genera in the garden, did much to fix in my mind a knowledge of the principles of the natural system. Specimens of the native plants being required to supply the students for the lectures, it was part of our duty to collect them; and thus the localities of most of the rare plants in the vicinity of Edinburgh, as far as the Pentland Hills, became known to me. Mosses and lichens were a special object of collection. Although our wages were only 9 s. per week I nevertheless managed to purchase paper for specimens, and a copy of Dr Smith's COMPENDIUM FLORAE BRITANNICAE. This work was in Latin, but with the aid of a Latin dictionary and the glossary of botanical terms in Lee's INTRODUCTION то вотАNy I was soon able to understand the Latin descriptions. The family of grasses and Cyperaceae also specially took my attention, and there being a fine collection of both native and foreign in the Garden, I made specimens of the whole collection. During this year I gained considerable knowledge of plants. ${ }^{1}$

In November I819 he went home to his father's for the winter, returning to Edinburgh in the spring of $\mathbf{1} 820$ when $\mathrm{McNab}$ gave him the choice of remaining in the Garden or of proceeding, with letters of introduction, to London. Smith chose the latter, presented himself to W. T. Aiton at Kew, and was immediately offered a

IJohn Smith in GARD. CHRON., (1876), p.363. 
post in the Royal Garden at Kensington. In I 822 he moved to Kew -to the propagating department, and in the autumn of 1823 was promoted to the post of foreman. From this time forth he was to be Aiton's right hand man, and, although he had been acting Curator for a number of years, it was not until I84I, when Aiton retired, and when Sir William Hooker became Director, that Smith was officially appointed Curator by the Treasury. And Curator he remained until his retirement in 1863 . 


\section{Interlude to}

\section{Parts Two and Three}

DURING THE REGIMES OF HOPE AND OF RUTHERFORD botanical events of great significance had been taking place in Europe. In France, Antoine Laurent de Jussieu had been elaborating the system of classification according to natural affinities developed by his uncle Bernard de Jussieu and in 1789 had published his genera plantarum. About 1800 , Christiaan Hendrik Persoon, born at the Cape of Good Hope, had taken up his abode in Paris and, although living in straitened circumstances and dying in poverty, published books of fundamental importance to the classification of the fungi; the SYNOPSIS METHODICA FUNGORUM of r8or was the first reliable systematic account of the fungi. In Sweden, Elias Fries, with some slight modification of Persoon's classification, in SYSTEMA MYCOLOGICUM (I82I-I829) had enumerated all fungal genera and species known at the time, and moreover had founded a system of classification for lichens based on the characters of fructifications. In Geneva, Théodore de Saussure had been publishing important discoveries in plant nutrition in his RÉCHERCHES CHEMIQUES SUR LA VÉGÉTATION of I8O4 and, by so doing, had laid the foundation for much future work on this matter. In Berlin, Christian Konrad Sprengel in his DAS ENTDECKTE GEHEIMNISS of 1793 had explained the structure of flowers, had shown that cross pollination was the rule rather than the exception and had distinguished wind pollination from insect pollination; and Carl Ludwig Willdenow and the traveller Alexander von Humbolt had been pioneering the scientific study of plant geography.

In England, Sir Joseph Banks was President of the Royal Society during the whole of Rutherford's reign. In $1766-67$ he had botanised in Newfoundland and Labrador and from $1768-7 \mathrm{r}$ had sailed on Cook's first great voyage of exploration through the Pacific, visiting Madeira, Rio de Janeiro, Tierra del Fugo, Tahiti, New Zealand, Australia (where he saw the plants of the genus which was later to commemorate his name-Banksia), the Dutch East Indies, 
South Africa, and St Helena. As President of the Royal Society, and as unpaid Director of Kew until he died in 1820 , he was formulating the policy of close collaboration with the Empire which was subsequently followed at Kew, and was sending out collectors to bring back new plants for gardens and herbaria. The first to journey from Kew was Francis Masson who collected at the Cape from $1772-73$, in the Canaries and the Azores from 1778-82, in Spain and Portugal from $1783-85$, and at the Cape again, as well as in the interior, from $1786-95$, and from these expeditions sent to Britain the first South African Heaths which were to become immensely popular during part of the I9th century and one of William McNab's specialities in Edinburgh, the Senecio species from which the florist's cinerarea has been evolved, Cape Pelargoniums from which were to be developed the garden geraniums so popular for bedding out purposes-and many another plant. Then in 1803 William Kerr, a foreman at Kew, was sent by Banks to Canton in China, at a salary of $f_{\mathrm{I}} \mathrm{IOO}$ a year, to collect plants for Kew. He introduced, among other things, the so-callcd Ogre Lily of Japan, Lilium tigrinum, which William Townsend Aiton so successfully propagated, by means of the purplish bulbils in the axils of the leaves, that by $18 \mathrm{I} 2$ over 10,000 bulbs had been grown at, and distributed from, Kew. On Kerr's departure from Kew, William $\mathrm{McNab}$ was promoted into his post.

Banks was also instrumental in founding the Horticultural Society of London, now the Royal Horticultural Society, in $\mathrm{I}^{804}$. He, John Wedgwood-the son of the great potter, William Forsythgardener to King George III at Kensington and St James, William Townsend Aiton, the Hon Charles Francis Greville-after whom the genus Grevillea was named, James Dickson the Covent Garden nurseryman who was to discover several new plants in the Scottish mountains, and Richard Anthony Salisbury, a friend of Banks's, were the founder members and were to pilot the Society through its first formativeyears.

In $178 \mathrm{I}$ James Edward Smith, son of a wealthy nonconformist woollen merchant in Norwich, was sent to Edinburgh to study medicine. Naturally he came under the influence of John Hope, learned from him the elements of the Linnaean system of classification according to the number and arrangement of the stamens and styles of the flower, and won one of Hope's gold medals. In $\mathrm{I}_{7} 83$ he came to London with an introduction from Hope to Joseph Banks who persuaded him to purchase Linnaeus's herbarium and library in 1784 . This done, he had the idea of establishing a Natural History Society, 
and thus was founded in 1788 the Linnean Society with Smith as its first President-an office he retained until his death in I 828-and with Banks as an honorary member. Smith devoted the rest of his life to incorporating all that was so far known of the British flora into a number of comprehensive works on this subject. ENGLISH BOTANY commenced publication in 1790 and was completed in I8I4; the work comprises all known British plants with the exception of the fungi, and Smith was responsible for the text of the 36 octavo volumes and James Sowerby for the 2,592 plates. In the meantime the three octavo volumes of his FLORA BRITANNICA were published between I800 and I804. Finally, from I824-I828, the four volumes of THE ENGLISH FLORA appeared, the last one in the year Smith died.

Another of the original founders of the Linnean Society was William Curtis, the quaker from Hampshire, who, trained as an apothecary, had become Director of the Chelsea Physic Garden in I772. Later he established a garden of his own at Lambeth and began publication of his magnificent FLORA LONDONENSIS in I775, the beautiful illustrations by Sydenham Edwards. Until the day it ceased publication in 1798 the FLORA was enthusiastically received by botanists but was always a financial liability and could never have carried on beyond 1787 had not Curtis's immensely popular BOTANICAL MAGAZINE proved so profitable. This BOtANICAL MAGAZINe, or "Flower Garden Displayed, in which the most ornamental foreign plants, cultivated in the open ground, the greenhouse and the stove, are accurately represented in their natural colours', was launched in I787. The price was one shilling per part of three hand coloured plates and the publication was issued from Curtis's botanical garden at Lambeth. The magazine was the first periodical devoted to scientific horticulture and today it is the oldest.

Still another student of Edinburgh University was to make his mark, and advance the cause of botany, in London. Robert Brown, son of an episcopalian minister in Montrose, in I80r accepted from Sir Josepl Banks the post of Naturalist to the Flinders Expedition to Australia. He was absent for four years, returning home with 4,000 specimens of dried plants many of which were new to science. In 1805 he was appointed Librarian to the Linnean Society, which post he held until I 822, and on the death in I8IO of Banks's Librarian -his friend Jonas Dryander-Brown filled the post of Librarian to Banks until I 820. Thus Brown sat at the heart of botanical affairs in England. Collections from all over the world came to him and 
formed the material for a long series of papers elucidating the morphology and anatomy, the geographical distribution and the natural affinities of the plant kingdom. His work did much to overthrow the artificial classification of Linnaeus and to put in its place one based on natural affinitics.

Not all botanical work in England was of a descriptive nature. There was experimental work also. Though Stephen Hales had died in $176 \mathrm{x}$, the year John Hope was appointed Regius Keeper in Edinburgh, the Dutch physician John Ingen-housz had arrived in England from Vienna, and, stimulated by the work of Joseph Priestley, had begun to study the relations between plants and the air. His numerous experiments culminated in the publication of his essay of 1779, Experiments with Vegetables, in which the processes of respiration and assimilation are quite clearly distinguished. Moreover, another of Banks's friends and a disciple of Stephen Hales, Thomas Andrew Knight, was one of the keenest students of plant physiology and was publishing in the PHILOSOPHICAL TRANSACtions of the Royal Society of London. His Observations on the Grafting of Trees of 1795 discusses inheritance of decay among fruit trees and the propagation of debility by grafting. His Experiments on the Fecundation of Vegetables of I799 describes experiments with peas which were begun in 1787 and which quite clearly show that Knight was observing dominance, recessive behaviour and heterosis almost 80 years before Gregor Mendel's day. His great paper On the Direction of the Radicle and Germen during the Vegetation of Seeds, read before the Royal Society in 1806 , illustrates the influence of gravitation and centrifugal force on the responses of seedlings.

In Scotland experimental work ended with the death of Professor Hope and botany almost entirely concerned itself with the discovery of the Scottish flora, in which, as we have seen, the Edinburgh Botanic Garden played its part. In 1762, the year after Hope was appointed Regius Keeper of the Garden, the London apothecary, William Hudson, published his FLORA ANGLICA, which, though an excellent compilation of existing knowledge of the British flora, contained only a few Scottish records. For the next considerable advance in the published record we have to wait until 1778 when the FLORA SCOTICA of the Rev John Lightfoot was published. Lightfoot's journey through Scotland was undertaken in 1772 at the invitation of the celebrated zoologist and antiquary, Thomas Pennant, who travelled with him gathering material for his TOUR. 
Though their itinerary is not given in detail much of it is not difficult to piece together. They journeyed "either by sea or land from the south of Annandale to the borders of Sutherland'. On the way to Sutherland they visited the Isle of Arran where Carex pauciflora was added to the British flora, and the islands of Bute, Jura, Colonsay, Iona, Islay, Mull, and Rhum. On the mountains of the latter island, Barkeval especially, they found the Scottish Asphodel Tofieldia pusilla, the purple Saxifraga oppositifolia, the Moss Campion Silene acaulis, the Mossy Cyphal Cherleria sedoides, the Alpine Meadow Rue Thalictrum alpinum, the Northern Rockcress Cardaminopsis petraea, and the dwarf willow Salix herbacea. In Skye, the recently discovered Eriocaulon was seen, as well as the Butterwort Pinguicula lusitanica, the Knotgrass Polygonum viviparum, the Bladderwort Utricularia minor, the Mountain Avens Dryas, the Black Bearberry Arctous alpinus, a hawkweed Hieracium alpinum, the Frog Orchis Coeloglossum viride, the Moonwort Botrychium lunaria, the Parsley Fern Cryptogramma crispa, and Isoetes the Quillwort. From the islands they came to Loch Maree where they gathered Hymenophyllum the Filmy Fern and Circaea alpina the Enchanter's Nightshade. On the way to Dundonnell they added two orchids to the British flora, Goodyera and Corallorhiza, neither of which has been seen in this locality since, as well as the two Wintergreens Pyrola secunda and P. minor. They explored Little Loch Broom and the mountains at the head of the Loch whereon they gathered the Dwarf Cornel Chamaepericlymenum suecicum and the Whortleberry Vaccinium uliginosum. Thence, by way of Creg-achnocaen-the boundary of Coygach and Assynt where they gathered Dryas, the two ferns Polystichum lonchitis and Asplenium viride, and in the lochs, Sparganium the Bur-reed-on to Tongue in Sutherland. On the return journey they did considerable exploration in Perthshire and probably visited Blair Atholl and Forfar on their way to Edinburgh and Kelso.

The FLORA marked a tremendous advance in our knowledge of the plants of Scotland, as about I,250 species, phanerogams and cryptogams, are listed. For the first time the richness of the flora of the Breadalbane mountains was made known, and Creag na Caillich, Meall Ghaordie, Meall-nan-Tarmachan and Bein Heasgarnich are familiar names in the pages of the FLORA. This was due in the main to a Perthshire botanist, the Rev John Stuart of Killin, who accompanied Lightfoot on his journeys.

Lightfoot and James McKay and Don and Hope's students were 
the pionecr explorers. Others followed. There was James Dickson, the Covent Garden nurseryman who paid two visits to Scotland and between I785 and I8OI issued a set of nineteen fascicles of plants. In 1789 he gathered on Ben Lawers the Blue Rock Speedwell Veronica fruticans, the Rock Whitlow-grass Draba rupestris-both new records for our flora-as well as the Alpine Flea-bane Erigeron borealis. Three years later, on the same mountain, Dickson discovered the Drooping Saxifrage Saxifraga cermua, and the small alpine gentian Gentiana nivalis. There was Thomas Drummond, who took over Don's Forfar garden, later became Curator of the Belfast Botanic Garden and accompanied Franklin on his second Arctic Expedition, and who issued two fascicles of Scottish mosses, recorded the Woolly Willow Salix lanata from Clova and discovered the vetch Lathyrus niger in the Den of Airlie, west of Forfar. There was Robert Brown, the Perthshire nurseryman who found Plyllodoce caerulea near Aviemore in I8I2. There was James Brodie of Brodie House who in 1793 discovered the Wintergreen Moneses uniflora the same year in which the plant was sent to the Linnean Society by Mr James Hoy, a gardener at Gordon Castle. There was Dr Alexander Murray of Aberdeen, author of the NORTHERN FLORA, a description of the wild plants of the North and East of Scotland. There was the friend of J. E. Smith, William Borrer, who added the yellow water-lily Nuphar pumila to our flora, and Professor Beattie of Aberdeen, the discoverer of Linnaea borealis in the pinewoods of Mearns in I795. The findings of all these-and of others-are partly recorded in Smith's 36-volume ENGLISH BOTANY.

One worker in this field is of special importance, Thomas Hopkirk of Paisley, author of the FLORA GLOTTIANA of I8I3. This is an enumeration of plants mainly obtained from the banks of the Clyde and the neighbourhood of Glasgow, some 662 species in all, of which about 40 are additions to the Scottish flora, but most of them aliens and casuals. Also in I8I3 Hopkirk published a catalogue of the plants cultivated in his garden at Dalbeth which in a few years were to form the nucleus of the new Botanic Garden in Glasgow which Hopkirk helped to found on an eight-acre site at the western part of Sauchiehall Street. Hopkirk raised funds by public subscription and to these funds the University made a substantial contribution. The establishment of this Botanic Garden was the prelude to the founding of the first Regius Chair of Botany in Glasgow, to which, in I8I8, Dr Robert Graham was appointed. 


\section{PART THREE}

\section{Botany at Inverleith}

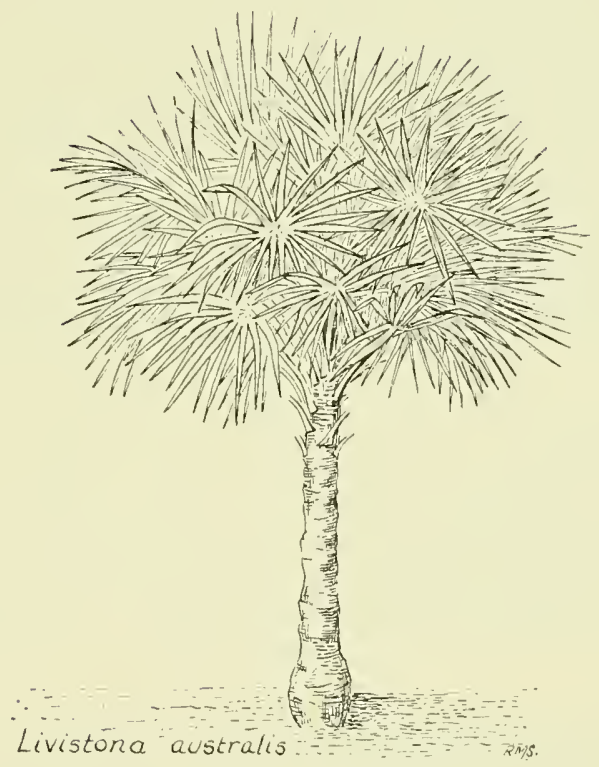





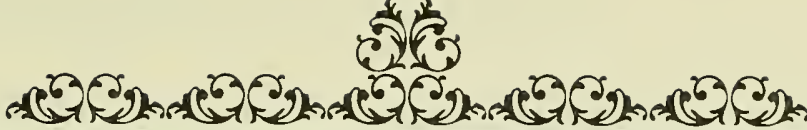

CHAPTER NINE

\section{Robert Graham}

THE QUESTION OF RUTHERFORD'S SUCCESSOR AROUSED CONsiderable interest in Edinburgh's scientific circle. THE EDINBURGH EVENING COURANT of 3 rd January I 820 summed up the feelings of many:

The deep interest which was taken by the public in the last election of a Professor, and the satisfaction which was felt at the independent and spirited conduct of the patrons of the University, are still fresh in our memory; this encourages us to hope that a similar preference will be given to the claims of the candidate of superior merit in the appointment of a Professor of Botany. Botany is one of the classes which all those students who intend taking the degree of Doctor of Medicine at this University are obliged to attend; and it is therefore of the utmost consequence to the interests of the medical school, on which so much of the reputation of the University depends, that the chair should be filled by a person of scientific eminence. As the duties of the Professorship do not commence until May, there is no necessity for haste in making the appointment; and we sincerely trust that full time will be given for the application of candidates.

For some three years there had been speculation about Rutherford's successor and Dr Patrick Neill and others were determined to secure the first botanist in the country, Dr Robert Brown, who was still Librarian to the Linnean Society as well as to Sir Joseph Banks. As early as i4th July I816 Neill was endeavouring to entice Brown to Edinburgh:

.... When I arrived here, I found speculation afloat as to a successor to the botanical chair. The cause of this has been removed for the present, by the recovery of the Profr sufficiently to go on with his course.

Now, what I would most sincerely represent to you is this-that you have only to take MD from St. Andrews (for which all due certificates, I know, are at your service), and you are qualified in case of a vacancy. You would have some great advantages at London; but you might spend 
two months in the capital every winter. The chair is surely honourablethe class, even now, is lucrative: While you advanced your own fame, or at best spread it wide, you would have the consolation of raising the name of Edinr.-its garden-and its medical school. Surely you might submit to some drudgery, and annoyance from raw and youthful botanists, to promote so many important ends; for I believe it would be somewhat annoying to you to descend botanically! - as it is to our good friend $\mathrm{Mr}$ Jameson to descend mineralogically. - In all this I am quite serious-and I can only speak the sentiments of all who know you here, or who can at all judge of your standing in the botanical world. With best wishes,

Yours truly,

(Sgd.) P. Neill. ${ }^{\mathrm{I}}$

Within four days of Rutherford dying, Neill was again trying to cajole Brown into coming to Edinburgh. He wrote on I9th December 1819:

Before this reaches you I trust that you will have made up your mind in favour of Edinburgh. I saw the letter of Dr Duncan Junr and can assure you that he speaks the sentiments of everyone here whose opinion is worth regarding. But those possessing the power are in general so completely ignorant, that means must be taken to let them know your status in the scientific world. It may sound strange to your ears to be told that certificates or testimonials are necessary. They may not be so to the Scavans of Paris, Vienna, or Berlin; but to the Town Council of Edinburgh, they are indispensable. A few letters from first rate characters will be enough. One or two from Paris could soon be got. Please do not overlook this matter.

A copy of the PRODROMUS TO THE FLORA OF NEW HOLLAND - of the Essay in the Appendix to FLINDERS VOYAGE - and of any papers in LINN. TRANS. etc. should also be sent to Edinburgh-with extracts of what has occasionally been said by foreign botanists. I know all this will be repulsive to your feelings; but it is necessary to prepare for contingencies.

You could come to Scotland and lecture in the summer of 1820 , and then spend the winter I820-2I in London; only finally leaving Lin. Soc. and Sir Joseph in March I82I.

Would not D. Don ${ }^{2}$ deserve the confidence of Lin. Soc. He writes botanical Latin well; reads French; is a most acute botanist; a lad of the most honourable gentlemanly feelings. He would soon acquire a little German and Italian.

Dear Sir, Yours sincerely, Pat. Neill.

Neill was by no means the only one imploring Brown to come to Edinburgh. There was Andrew Duncan, Jnr, mentioned in Neill's letter, who informed Brown on rgth December that it would be

I Patrick Neill to Brown: Brown Corresp., Brit. Museum.

2 Son of George Don, Rutherford's Principal Gardener, 1802. 
necessary for him to reside in Edinburgh only for three months in the year-May, June, July; the rest of the time he could give to his work in London. '. . . . I trust that Sir Joseph [Banks] from his zeal for Botanical science and his generally liberal views will himself urge you to accede to the universal wishes of those to whom I hope you will soon be a Colleague.' There was Alex. Henderson, a member of the Town Council, who described Edinburgh and the Botany Chair as 'a place of much respectability', adding 'and from your great experience and research [you] would be an acquisition to your Native Country and to the Modern Athens'. ${ }^{I}$

The Rev George H. Baird, Principal of the University of Edinburgh, canvassed on Brown's behalf by writing to Lord Melville and to the Earl of Morton. He wrote to Lord Melville on Isth December, the day of Rutherford's death: 'Mr Brown .... is held throughout Europe as the first Botanist of the age and if he can be prevailed on to accept the vacant chair there is no doubt that he would increase both the prosperity and the fame of the University.' And Mclville wrote to Banks, in whose household Brown was living: 'If $\mathrm{Mr}$ Brown is willing to accept the situation I can have no difficulty as to using my best endeavours to carry into effect Principal Baird's suggestion in his favour-the appointment is in the Crown."

Three days later Baird, at considerable length, explained the whole position to the Earl of Morton:

The Professor of Botany holds one Commission from the Crown and one from the Town Council. By the first he is made King's Botanist for Scotland and Keeper of the Regius Botanical Garden. By the second, Professor of Medicine and Botany in the University in which last character he becomes a member of the Medical Faculty and Examinator of Candidates for Graduation. To make the joint offices useful it is obvious that they must be held by the same person-a King's Botanist would as such merely have no right to teach in the College, a Professor of Medicine and Botany would as such merely have no right to enter and teach in the Botanical Garden.

The emoluments of both offices-with all the duties of both donewould amount to upwards of considerably $£ \mathrm{I}, 000$ per an.

Part of this sum arises from Clinical Lectures given in the Infirmary and for examination of Medical Candidates for Graduation. But the friends of some Candidates here are disposed to hint that $\mathrm{Mr}$ Brown might not hold himself fully competent to the discharge of these duties from having lately devoted himself pretty exclusively to other pursuits than those strictly medical.

I Brown Correspondence, British Museum.

2 ibid. 
It is chiefly in reference to this view of the case I wish to give an explanation to Your Lordship. In the first place then-all Mr Brown's personal friends have a perfect conviction from their knowledge of his qualifications and character that he is fully competent-But in the next place I am anxious that it should be distinctly understood-that he is not bound by any one of the commissions to undertake any one of the duties-undertaking them is entirely optional to the members of the Medical Faculty-several of whom accordingly never give Clinical Lectures (Dr Gregory, Dr Hope and Dr Monro for instance) and in the same way, any Professor choosing to decline the Examination of Candidates would find his colleagues quite willing to relieve him of the duties if the emoluments were no object to himself. ${ }^{\mathrm{I}}$

But, in spite of all the entreaty, Brown was unmovable; he refused to sever the Banksian connection and stayed in London.

Robert Brown was not the only botanist whom those in authority in Edinburgh thought would be suitable for the vacant Chair. If the Secretary of the Linnean Society refused to move to Edinburgh, perhaps the President of the Society would be persuaded. At the end of a letter to Brown on I6th December, Neill says: 'If you decline, would Sir J. E. Smith come forward?' But, like Brown, Smith was not to be persuaded to leave London. Brown declined the post on 20th December and on that same day, or the day following, the appointment was given to Dr Graham of Glasgow who was then the only candidate in the field. THE EDINBURGH EVENING COURANT of IOth January I820 greeted the news enthusiastically:

We understand that the appointment of Dr Graham to the vacant botanical chair in our University, gives universal satisfaction. He has filled the Botanical Professorship in the University of Glasgow with much celebrity, and has great merit in forming and improving the new Botanical Garden there. The Government, with their usual attention to the encouragement and promotion of science, have lately purchased some acres of ground in a fine situation in the neighbourhood of Edinburgh, for a new Botanical Garden for the University, to be laid out and formed under the management and superintendence of Professor Graham.

Robert Graham (Plate vb) was born at Stirling on 7 th December I786, the third son of Dr Graham, afterwards Moir of Leckie, and in Stirling he received his early education. In 1804 he was apprenticed to $\mathrm{Mr}$ Andrew Wood, surgeon in Edinburgh, and became a licentiate of the College of Surgeons in I808, graduating $M D$ at the University in the same year. Thereafter he studied for a

I Brown Correspondence, British Museum. 
year in London, at St Bartholomew's hospital, before commencing practice in Glasgow, where in 1812 he was appointed physician to the Infirmary and lecturer in Clinical Medicine. During this period he published an essay On Continued Fever which was epidemic in Glasgow. In the University of Glasgow at this time botany had not acquired the dignity of a Professorship. It was attached to the Chair of Anatomy, although a separate lecturer undertook the teaching. To this lectureship, in I8I7, Graham was appointed in succession to Dr Thomas Brown who bad held the post since I80o, an appointment which proved to be the prelude to his selection to the new Chair of Botany the following year. The foundation of the Chair in some measure appears to have been due to Graham's influence with the Duke of Montrose, the Chancellor of the University, of whose house Graham was a cadet. His appointment coincided with the efforts of Thomas Hopkirk to raise the funds, by private subscription, necessary for the establishment of a Botanic Garden. To the united efforts of these enlightened subscribers the University contributed $f_{2}, 000$ on the understanding that a room would be set aside for the Professor of Botany in which he could lecture, using materials supplied by the Garden. In I8I8 the Crown also contributed, and granted a Royal Charter which styled the new Society 'The Royal Botanic Institution of Glasgow'. Sir Ilay Campbell of Succoth was President, Hopkirk Vice-President and Stewart Murray the Curator of the Garden. Once the ground at the west end of Sauchiehall Street had been purchased from Mr Campbell of Blythswood, Graham played the major role in the establishment of the Garden. But not for long; Professor Rutherford died on Isth December I8I9 and, before the end of the year, Graham had succeeded him.

On 5th January I820 he was appointed Professor of Medicine and Botany in the University-by the Town Council. On 3 Ist January his appointments of Regius Professor of Botany in the University, Keeper of the Royal Botanic Garden, and King's Botanist, were ratified, with a 'salary' of froo sterling money, to commence from the Isth day of December last'. This shows that Graham was appointed to the Garden by the Crown before the Town Council made him its Professor in the University, and published notices of Graham mention his being gazetted Crown Professor in December I8I9. The salary, it will be noted, was increased to fioo.

In Edinburgh Graham was forced to take up medical practice 
and clinical teaching in the hospital and to interest himself in the affairs of the Royal College of Physicians, of which ultimately he was to be President-all this, as with his predecessors, in addition to his botanical work. Straightway he was confronted with a major task-the transference of the Botanic Garden to a new site.

This project had been initiated by Rutherford. The five-acre Garden established by John Hope could no longer accommodate its collections properly; the glasshouses were in a dilapidated condition and the ground surrounding the Garden, which had been mostly occupied by nurseries, was in process of being over-built. A new site had to be found. And indeed a new site had been found, and had been purchased by the Barons of Exchequer, in the vicinity of the Palace of Holyroodhouse. Not everyone favoured the site. Those who did advanced the argument that, on the new site, money for the Garden's maintenance would be more easily got from the Barons of His Majesty's Exchequer. Moreover its proximity to the Royal Palace and to the King's Park was regarded as a decided advantage; the latter could be used as an extension to the Garden and the remarkable opinion was expressed that Salisbury Crags could form a natural rock garden where McNab's collection of Cape Heaths could be cultivated. Again, the situation was a convenient one for the University medical students most of whom lodged on the south side of Edinburgh. In the end these arguments failed. The soil and aspect were unfavourable, and the Barons of Exchequer were induced to purchase another site, some fourteenand-a-half acres in extent, beside the Garden of the Royal Caledonian Horticultural Society at Inverleith.

The land now chosen for the site of the Botanic Garden was part of Broompark or Quacaplesink, its owner being Mr James Rocheid. An eminent agriculturist, he was also a man of inordinate vanity and family pride and it was one of the sights of Stockbridge to see his portly figure, in the old family carriage covered with heraldic blazons, passing to and from the City. No less distinguished was his mother, according to Cockburn in MEMORIALS OF HIS OWN TIME:

Except Mrs Siddons in some of her displays of magnificent royalty, nobody could sit down like the Lady of Inverleith. She would sail like a ship from Tarshish, gorgeous in velvet or rustling silk done up in all the accompaniment of fans, ear-rings, and finger-rings, falling sleeves, scent bottle, embroidered bag, hoop and train, all superb yet all in purest taste; managing all this seemly heavy rigging with as much ease as a fully blown swan does its plumage. She would take possession of the centre of a large sofa, and at the same 
moment without the slightest visible exertion cover the whole of it with her bravery, the graceful folds seeming to lay themselves over it, like summer waves. The descent from her carriage too, where she sat like a nautilus in its shell, was a display which no one in these days could accomplish or even fancy. The mulberry coloured coach, apparently not too large for what it carried, though she was alone in it-the handsome, jolly coachman and his splendid hammer-cloth loaded with lace-the two respectful liveried footmen, one each side of the richly carpeted step, these were lost sight of amidst the slow majesty with which the lady came down and touched the earth. She presided in this imperial style over her son's excellent dinners with great sense and spirit to the very last day almost of a prolonged life.

The Rocheids lived in Inverleith House, now the Gallery of Modern Art. The present tea-room, for so long the office of the Regius Keeper, was the Rocheid stables. The lodge at the West Gate entrance to the Botanic Garden in Arboretum Road was the Rocheid gardener's house. At the entrance to the lane which now flanks the Grange grounds by the 'Colonies' were the big entrance gates of the Rocheid estate and the gate-keeper's lodge. The lodge, and the two columns of the gates, are still in existence. Parts of Broompark were planted with trees, but, apart from a kitchen garden on the site of the present lawn in the Botanic Garden devoted to a collection of species of Pyrus, there was no pretence at a garden. From the House a path led to the kitchen garden, across the present Chestnut Lawn, through great sycamores to the south-west of the House. The Botanic Garden was barely established on its new site when James Rocheid died in I824.

The site for the Garden was separated from the rest of the Broompark estate by a wall which ran south from somewhere near the end of what is now Inverleith Place Lane to Inverleith Terrace, to a point where the present boundary railing of the Botanic Garden is at two different levels. Part of the brick wall separating the Botanic Garden from the Experimental Garden of the Royal Caledonian Horticultural Society can still be seen just to the north of the East Gate entrance to the Garden.

Nearly two years were required to move the contents of Hope's Garden in Leith Walk to the new site at Inverleith and for the success of the operation Graham and his Principal Gardener, McNab - especially the latter-must take the credit. The task of transporting and successfully transplanting well-established trees and shrubs could not have been an easy one. $\mathrm{McNab}$ was not deterred however; he invented a transplanting machine specially for the purpose, a somewhat cumbersome and crude version of the tree 
transplanting machines of today, but obviously efficient for all that. The removal to Inverleith is described by Sir Henry Steuart in the PLANTER'S GUIDE:

Dr Robert Graham .... contrived to remove a vast number of plants of great rarity and value, and which, had they been lost, many years of the most diligent culture in the ordinary manner would not have replaced. Previous to the taking-up, he followed the ingenious method of Lord Fitzharding, in cutting round the plants, which, properly speaking, should all have stood for two or three years after, in order to gain an accession to their roots. But, some local arrangements having deprived them of that advantage, a great part were suffered to stand only for a single season. Such, notwithstanding, was the extraordinary care bestowed on them by the ingenious Professor, and the skill and diligence of his Gardener Mr McNab, that the Removals were executed with a safety, which could scarcely have been anticipated. In order to give still greater variety and effect to the new Garden, Forest Trees also of various kinds, and considerable dimensions, some of them from thirty to forty feet high, were at the same time transferred from the old ground to the new.

The method adopted was, to raise as great a mass or ball of earth as possible with the plants, and that was carefully matted up, in order to preserve it entire. The plants were then put upon a platform with four very low wheels, in an upright position (as was practised in the time of Evelyn), and transported about a mile and a half to the new Garden. In removing the Trees, owing to the immense friction occasioned by the lowness of the wheels, ten and twelve horses were occasionally employed; so that the procession through the suburbs for many days, consisting of men, and horses, and waving boughs, presented a spectacle that was at once novel and imposing. The citizens of Edinburgh were surprised and delighted with the master of an Art, which seemed more powerful and persuasive than the strains of Orpheus, in drawing after it, along their streets, both grove and underwood of such majestic size;

\section{Threicio blandius Orpheo}

Auditam moderari Arboribus fidem.

On arriving at the place of their new destination where the ground had been prepared at great expense, and forced up to the depth of three feet or more, the Trees and bushes were carefully planted. Numerous ropes, fastened pretty high from the ground, and extending from the stems to the distance of from twelve to four-and-twenty feet out, in the fashion of a well-pitched Bell-tent, pinned them to the spot with immovable firmness, so that injury from wind seemed altogether impossible. In this way, as may be easily conceived, little or no loss of plants could be sustained by the operation: The depth and richness of the soil; the sheltered site of the Garden, almost as low as the level of the sea; the steadfastness of the plants, in consequence of their fastenings; added to careful waterings daily repeated, almost precluded contingency. ${ }^{1}$

ISir Henry Steuart, the Planter's guide, ed. 2 (1828), p.63-65. 
Graham provided Steuart with a list of over 30 of the largest trees which were moved:1

\begin{tabular}{|c|c|c|}
\hline & Height & $\begin{array}{c}\text { Girth at } \\
\text { I } f t\end{array}$ \\
\hline ommon Hawthorn (Crataegus oxycantha) & $23 \mathrm{ft}$ & $2 \mathrm{ft}$ io in \\
\hline Scarlet-flowering Hawthorn (Crataegus oxycantha var.) & $20 \mathrm{ft} 9$ in & I ft $9 \frac{1}{4}$ in \\
\hline Great American Hawthom (Crataegis intricata & & \\
\hline or C. rotundifolia) & $20 \mathrm{ft} 6 \mathrm{in}$ & I $\mathrm{ft} 7$ in \\
\hline Spotted Hawthorn (Crataegus punctata) & I7 ft & $2 \mathrm{ft} 4 \mathrm{in}$ \\
\hline Cut-leaved Alder (Alnus glutinosa var.) & $43 \mathrm{ft}$ & $3 \mathrm{ft} \mathrm{II}$ in \\
\hline Weeping Ash (Fraxinus excelsior var.) & $34 \mathrm{ft}$ & $2 \mathrm{ft}$ io in \\
\hline eart-leaved Poplar (Populus candicans) & $29 \mathrm{ft}$ & $2 \mathrm{ft}$ I in \\
\hline arious-leaved Ash (Fraxinus excelsior 'Heterophylla') & $34 \mathrm{ft} 9$ in & $2 \mathrm{ft} \quad 7 \frac{1}{2}$ in \\
\hline owering Ash (Fraxinus ornus) & $37 \mathrm{ft} 8$ in & $3 \mathrm{ft} I \pm \frac{3}{4}$ in \\
\hline Common Lime (Tilia europaea) & $37 \mathrm{ft} 8$ in & $2 \mathrm{ft} 6 \mathrm{in}$ \\
\hline White Lime (Tilia tomentosa) & $30 \mathrm{ft}$ & $3 \mathrm{ft} 2$ in \\
\hline White Beam (Sorbus aria) & $34 \mathrm{ft} 6$ in & $3 \mathrm{ft} \quad \mathrm{I}_{2} \mathrm{in}$ \\
\hline Weeping Birch (Betula pendula) & $40 \mathrm{ft}$ & $2 \mathrm{ft} 9$ in \\
\hline Iontpelier Maple (Acer monspessulanum) & I9 $\mathrm{ft}$ & $2 \mathrm{ft} 5$ in \\
\hline Common Walnut (Juglans regia) & $24 \mathrm{ft} 6$ in & $2 \mathrm{ft} 4 \mathrm{in}$ \\
\hline Common Yew (Taxus baccata) & $23 \mathrm{ft}$ & $3 \mathrm{ft} 5 \frac{3}{4}$ in \\
\hline Sugar Maple (Acer saccharinum) & I $8 \mathrm{ft} 6$ in & $\mathrm{I} \mathrm{ft} 9$ in \\
\hline ering Maple (Acer rubrum) & I9 $\mathrm{ft}$ & I $\mathrm{ft} x$ in \\
\hline Scarlet Oak (Quercus coccinea) & I $8 \mathrm{ft} 8$ in & I $\mathrm{ft} \quad 5 \frac{1}{2}$ in \\
\hline Shell-bark Walnut (Juglans cinerea) & $17 \mathrm{ft}$ & I $\mathrm{ft} \quad S_{2}^{\frac{1}{2}}$ in \\
\hline Perfumed Cherry (Prunus mahaleb) & $\mathrm{I} 8 \mathrm{ft}$ & $2 \mathrm{ft} 7 \frac{1}{2}$ in \\
\hline Chinese Arbor Vitae (Thuja orientalis) & $17 \mathrm{ft}$ & $2 \mathrm{ft} 9 \frac{1}{2}$ in \\
\hline Red Cedar (Jimiperus virginiana) & $\mathrm{I} 8 \mathrm{ft}$ & I $\mathrm{ft}$ Io in \\
\hline Common Holly (Ilex aquifoliuni) & $2 \mathrm{I} \mathrm{ft}$ & $\mathrm{I}$ ft $\mathrm{II}_{2}^{\frac{1}{2}}$ in \\
\hline Hedgehog Holly (Ilex aquifolium var.) & II $\mathrm{ft}$ & $\mathrm{I} \mathrm{ft} \mathrm{I}$ in \\
\hline Thick-leaved Holly (Ilex aquifolium var.) & $12 \mathrm{ft} 2 \mathrm{in}$ & a bush \\
\hline Strawberry Tree (Arbutus andractine) & I $3 \mathrm{ft}$ & $2 \mathrm{ft} \quad 7 \frac{1}{2}$ in \\
\hline Shrubby Trefoil (Ptelea trifoliata) & ro $\mathrm{ft}$ & I $\mathrm{ft}$ \\
\hline Blue Magnolia (Magnolia acuminata) & $13 \mathrm{ft} 6$ in & I $\mathrm{ft} 3 \frac{3}{8}$ in \\
\hline Constantinople Hazel (Corylus colurna) & $25 \mathrm{ft} 4$ in & $2 \mathrm{ft} \quad \mathrm{o} \frac{1}{2}$ in \\
\hline Cut-leaved Hornbeam (Carpinus betulus var.) & $\mathrm{I} 2 \mathrm{ft}$ & $2 \mathrm{ft} 3$ in \\
\hline merican Nettle-Tree (Celtis occidentalis) & $\mathrm{I} 4 \mathrm{ft}$ & $\mathrm{I} \mathrm{ft}$ ro in \\
\hline Ulmus americanus) & 25 & I $\mathrm{ft} \quad 9 \frac{1}{2}$ in \\
\hline Irled-leaved Elm & $28 \mathrm{ft} 6 \mathrm{in}$ & $2 \mathrm{ft} 2 \frac{1}{2}$ in \\
\hline
\end{tabular}

\section{Steuart visited the Botanic Garden in June 1823}

.... when the oldest of the Trees had not been longer than a twelve month in the ground; and this effort appeared the more admirable from the circumstance, of which I was at the same time informed, that only one, or two at most, had died in the first season. On visiting the Garden again in July 1827 , I was both pleased and surprised to observe, that the more delicate plants, such as the Magnolia, the Perfumed Cherry, the Arbutus, etc. had succeeded

'Sir Henry Steuart, the planteR's guide, ed. 2 (I828), p.4r3. 
the best; which showed the extraordinary care and judgment, with which, on account of shelter, they had been massed up with others, and also the extraordinary attention, which had been bestowed upon them afterwards. Of the Arbutus there is a noble specimen, supposed to be one of the largest in Britain.

The ordinary Forest-Trees, on the other hand, such as the Lime, the Birch, and the Walnut, appeared by no means successful, although powerfully supported with cordage .... but they were placed in more exposed situations, and seemed less in possession of the Protecting Properties. This conjecture was confirmed to me by the intelligent $\mathrm{Mr} \mathrm{McNab}$, who stated, among other things, that in the tallest of these Trees, which were from seven-andthirty to three-and-forty feet high, the roots did not exceed three and a half or four feet in length; a style of root, as I observed to him, wholly inadequate to nourish or support plants of a far smaller size . . . But I wish distinctly to repeat .... that I consider Dr Graham as beyond comparison the ablest, the most ingenious, and the most successful Horticultural Transplanter in Britain, or perhaps in Europe; and I am certain, that he would render an important service to all others, who may be placed in similar circumstances, were he to publish an account of the particular process which he followed, on this interesting occasion.

Graham published no account of the transplanting, but $\mathrm{McNab}$, the practical gardener, did, in 1830 , in an important paper Hints on the Planting and General Treatment of Hardy Evergreens in the Climate of Scotland. Two years later he published his other main contribution to botanical and horticultural literature, a paper on the Propagation, Cultivation and General Treatment of Cape Heaths, a group of plants he grew with remarkable success in the new Garden. ${ }^{1} \mathrm{McNab}$ was now among the foremost horticulturists in the land and it would have been strange if his excellence had not been recognised by an increase in salary which, by two instalments, was raised to fioo. In 1834 a further advance was made to $£$ I 50 a year.

Graham's published botanical work was in the main concerned with the systematic description of new species of plants, many of them being grown in the Botanic Garden, in the EDINBURGH NEW PHILOSOPHICAL JOURNAL and in the BOTANICAL MAGAZINE. Between I 826 and I844, the year before he died, he was instrumental in over 200 plants in the Garden (and occasionally in the Garden of the Royal Caledonian Horticultural Society) being figured and described in the BOTANICAL MAGAZINE and for the descriptions of the great majority of these he was responsible.

I The cultivation of Heaths was much in vogue at this time, the Edinburgh Professor of Greek, Dr George Dunbar, cultivating, in 1826, some 350 different kinds in a glasshouse at his home, Rose Park, near Edinburgh. 
At first he was often content merely to send the material to William Jackson Hooker in Glasgow for figuring and for description for the MAGAZINE, as with Cinnamomum camphora the Camphor tree of Japan, Isolobus corymbosus of the Cape of Good Hope, and Lobelia coronopifolia of South Africa, of I826. However, from I83 I onwards Graham usually sent an ample description of the plant with the material for figuring. The same plant would sometimes also be described in the EDINBURGH NEW PHILOSOPHICAL JOURnal, as were the Mexican Bouvardia triphylla, the Chilean Gardoquia multiflora and Erysimum perofskianum from the Caucasus, and others. Occasionally he would contribute to the MAGAZINE a description of a plant he himself was unable to determine, and then others-William Hooker for instance-would affix the name. In 1840 , for instance, Hooker named one such plant, an orchid from Cuba, Epidendrum grahamii, in Graham's honour. Unfortunately the orchid was not a new species and has since been determined as Epidendrum phoenicium.

In this fashion the Botanic Garden gave Graham the material for most of his botanical publications. Unfortunately he, in turn, had to give the Garden funds from his own private resources for the Government grant was utterly inadequate for the Garden's proper maintenance. In 1833 the annual grant to the Garden had been fixed at $\mathcal{L}^{\mathrm{x}, 000}$ and this sum had to cover $\mathrm{McNab}$ 's wages and the wages of his assistants, the cost of fuel, soil, materials and specimens, as well as the maintenance of a museum which had recently been erected.

Graham was unsparing in his efforts to place the Garden on a proper footing and always optimistic that one day his strong representations to the Government as to the insufficiency of the accommodation in the hothouses would be fruitful. His optimism was justified. He secured the support of the Hon T. F. Kennedy of Dunure, later to be one of Her Majesty's Commissioners of Woods and Forests, and soon the glasshouse accommodation was vastly improved, especially the accommodation for Palms. Graham must have been a proud man when, in 1834 , he was able to open a new Palm Stove, octagonal in form, with a diameter of $60 \mathrm{ft}$ and a height of $47 \mathrm{ft}$ from the floor to the apex of the conical roof which was of wooden rafters and covered with glazed sashes. At that time the Stove was the largest house of its kind in Britain, had been built at a cost of 'upwards of $f_{1}, 500$ '-and Government had advanced the funds. It was heated at first partly by steam and partly 
by hot water; subsequently hot water alone was used. There were two cast-iron boilers, with distinct arrangements of cast-iron pipes attached to each, so that one or both might be used as required. About the years I $847-48$ the boilers and pipes had to be renewed, and much later still certain other modifications to the house were made by Professor Bayley Balfour.

Such was the environment in which Graham taught his students. That he was a popular teacher is shown by the fact that in the summer of 1828 his class numbered 280 members. Wrote one of them:

The morning walk to the Botanic Garden, the large light conservatory looking lecture-room, surrounded by fine shrubs and beautiful flowering plants, the abundance of newly gathered flowers, with which the lectures were illustrated, and the lecturer himself, simple, unaffected, cordial, and joyous, with no dullness or tedium in him, but as fresh and healthy, and full of life, as the youths around him, remain as a permanent picture in the mind's eye, from which so many scenes have altogether faded.

The Professor took great pains in laying a solid foundation, by dwelling upon the structure and functions of the organs of plants and their classification, in which he adhered pretty closely to the Linnaean principles. In his early lectures, he allotted but a very limited portion of the course to the consideration of the Natural Classification, and only illustrated those orders which contained the more important medicinal plants, at the same time describing their properties. Latterly, however, after giving a view of the Linnaean arrangement, and treating of genera, he proceeded to speak of species in Natural Families at greater length. He also divided the hour of the lecture, dedicating the first half to Physiological details, and the remainder to Practical Botany, illustrating his observations by specimens handed to the students. He found that in this way their attention was better sustained. Their knowledge and progress he ascertained Ist by setting apart a small portion of the hour to oral examination; 2dly, by affixing numbers to particular plants in the Garden, and desiring the students to tell him on the following day what these were. On the Saturdays he invited them to accompany him on botanical excursions in the neighbourhood. These trips sometimes extended over fifteen miles; and, enjoyed alike by the teacher and the taught, they contributed in no small degree to impart a lively interest in their studies in the Lecture-Room and Garden. ${ }^{I}$

To stimulate interest annually he presented a gold medal to the student with the best herbarium, and another for the best essay on some particular botanical subject. That some, at any rate, of these essays were pieces of sound research is shown by the fact that

\footnotetext{
I Charles Ransford, BIOGRAPHICAL SKETCH OF THE LATE ROBERT GRAHAM, MD, FRSE (1846).
} 
H. C. Watson's BOtANICAL GEOGRAPHY first took the form of one of them.

Graham's excursions were by no means confined to Saturdays and to the neighbourhood of Edinburgh. Annually in the months of August and September, accompanied by William McNab, some of his students and a few of his friends, he would travel through various parts of Scotland, England and Ireland, examining, and in search of, the native flora. As a result of these excursions several additions to the British flora were made, including Ononis reclinata which he found in 1835 , by the sea, to the north of West Tarbert near the Mull of Galloway, and Astragalus alpinus which he, with one of his students William Brand, and Robert Kaye Greville, author of the SCOTTISH CRYPTOGAMIC FLORA, discovered in Glen Doll, Clova, in I83I. On these excursions his average daily walking distance was some twenty miles; occasionally, to reach some particular place, the daily walk could amount to fifty miles. Nothing appeared to discourage him and any inconvenience was countered with good temper. His diary of a trip to the Wcst of Ireland amply illustrates this:

\footnotetext{
We left Galway, and arrived at Oughterard. From a blunder, however-for such things, notwithstanding the march of intellect, do occasionally happen, even in Ireland - a bed too few was provided, and I padded a deal form with a plaid belonging to one of the party, wrapped myself in a blanket belonging to another, and slept soundly in this Protestant-murdering Country, without putting a bolt on either door or window; for this reason, amongst others, that neither door nor window had one.
}

Thus Graham worked unsparingly for the Botanic Garden, for systematic botany and for his students at the same time as he practised medicine and taught in the Hospital. Gradually however his strength and activities became impaired and in the autumn of I 843 he made his last botanical excursion. By May I 845 he was unable to conduct his classes at the Botanic Garden and arranged that Dr Joseph Hooker should deputise for him. By August he had died.

As a Scottish botanist Graham was greatly overshadowed by his successor in Glasgow, William Jackson Hooker, who, appointed to the Glasgow Chair in I820, for the next twenty years raised the Glasgow Department and Garden to one of considerable eminence and largely dominated Scottish botany, publishing his FLORA SCOTICA in I82I and his BRITISH FLORA in I83O. 
However there is no gainsaying the fact that Graham's influence on botany in Edinburgh and in Scotland was far reaching through his championing of the Botanical Society of Edinburgh which he helped to form in 1836 and for the success of which he strove to the end of his life. 


\section{CHAPTER TEN}

\section{The Botanical Society of Edinburgh}

ON THE EVENing OF $8 \mathrm{TH}$ February i 836 , TWELVe OF Graham's former pupils met at No. Is Dundas Street, Edinburgh, at the invitation of Dr John Hutton Balfour, an Edinburgh physician. The men in question were William Hunter Campbell, soon to take up a post in Demerara; William Brand, ws, a keen amateur botanist who, with Graham and R. K. Greville, had discovered Astragalus alpinus in Clova in I83 I; James $\mathrm{McNab}$, the eldest son of William $\mathrm{McNab}$ and Superintendent of the Gardens of the Royal Caledonian Horticultural Society; Gilbert McNab, the third son of William, who in two years' time was to travel to Jamaica and devote much time to the study of the flora of the island; Edward Forbes, who was to be Professor of Botany in King's College, London, and, later, Regius Professor of Natural History in Edinburgh; Giles Munby, who had been a pupil of Adrien de Jussieu and was to spend twenty years in Algeria and become an expert on its flora; Nicholas Tyacke, shortly to be a practising doctor in Chichester and always to maintain an interest in the flora of the region; Richard Chandler Alexander, who later was to take the name of Prior and have a genus Prioria named after him; Richard Parnel, the ink manufacturer and an expert on British grasses; Edward Charlton, a medical practitioner of Newcastle; George Charles Wallich, son of the celebrated botanist Nathaniel Wallich, who was to enter the Indian Medical Service; as well as the man who was to succeed to Graham's Chair-Balfour himself.

The meeting was convened with the object of discussing the desirability of forming, in Edinburgh, an association or society to be devoted exclusively to the advancement of botanical science. It 
is true that already, in Edinburgh, there were several societies designed for the promotion of the various branches of natural history; there was the Royal Society of Edinburgh, for instance, which had been founded in $\mathrm{r} 783$, as well as the Wernerian Natural History Society, of which for many years Patrick Neill was Secretary, which had been established in I806. But, although botanical matters were sometimes discussed by these societies, botany as a science was not receiving the attention to which its expanding concepts entitled it. Thus, in Balfour's home at Is Dundas Street, it was agreed 'to bring Botanists more immediately together, and to concentrate their efforts towards the production of original Papers, the formation of a public Herbarium and Library, the extension and improvement of private Herbaria, and generally, towards the promotion of Botanical Science in all its ramifications.' ${ }^{\prime}$ This indeed seemed a worthy aim in a city where there existed a University and a Medical School which every year sent forth zealous students of botany to all parts of the world.

Graham, warmly approving of the scheme, offered the use of his classroom for the Society's meetings and was elected the first President at the first regular meeting on 17 th March, when the number of original members was twenty-one. In addition to the above twelve, there were present: Graham; Robert Kaye Greville, author of several works on botany, especially on cryptogamic botany; the noted botanist and horticulturist Patrick Neill, the Secretary of both the Wernerian and of the Caledonian Horticultural Society; Martin Barry the embryologist; George Arnold WalkerArnott, the future Professor of Botany in the University of Glasgow; David Falconer of Carlowrie; Robert Maughan, who in the first volume of the MEMOIRS OF THE WERNERIAN NATURAL HISTORY society of I8II had published $A$ List of the Rarer Plants Observed in the Neighbourhood of Edinburgh; David Steuart; and William McNab, Graham's Principal Gardener.

In addition to the election of Graham as President, Greville and Balfour filled the offices of Vice-Presidents, Neill, Falconer, Barry, Munby and Tacke, the Councillors, Campbell the Secretary, Forbes the Foreign Secretary, Brand the Treasurer and James $\mathrm{McNab}$ the Curator. And at this first meeting on I7th March, Walker-Arnott and Neill offered the Society all the duplicate material from their various herbaria.

${ }^{1}$ Bot. Soc. Edinb. First Annual Report (I 837), p.5. 
Thus instituted on I7th March 1836, the Botanical Society of Edinburgh issued a Prospectus of its Laws and intended activities at its first open meeting held on I4th April. It said:

The operations of the Society will for some time be confined principally to the holding of Periodical Meetings,--to Correspondence,- to the formation of an Herbarium, - and to the establishment of a Medium of Intercourse for the exchange of Specimens between Botanists at home and abroad .... The value of an authentic Herbarium, especially to the resident Botanist, must be obvious; and this will, therefore, receive particular attention. The peculiar feature, however, in the constitution of the Society, is the provision made for the interchange of Specimens .... The Flora of Edinburgh, which is particularly rich, will afford a constant supply of valuable duplicates, and many rare species will be annually obtained from the mountainous parts of Scotland.

To those interested in the flora of Scotland today, those last words ring ominously.

Clearly, from the Laws of the Society, the exchange of specimens was contemplated on a large scale. To enable him to participate in the distribution of specimens a Resident Member was required to contribute yearly 'not less than fifty species of plants, with as many duplicate specimens of each as possible'. The obligation of a Foreign Member amounted to 'soo specimens (including at least Ioo species)', at the time of his election, and ' 300 specimens, including at least so species' annually thereafter.

Originally $2 I$, the number of members at the end of the first year was I32; 6 British Honorary Members, I9 Foreign Honorary Members, 58 Resident Fellows, 45 Non-Resident Fellows, 3 Foreign Members, and I Associate. And the number of specimens which had been received comprised upwards of 30,000 British plants and nearly 30,000 foreign-including the East Indian Herbarium of the Countess of Dalhousie.

The initial enthusiasm continued and, in I839, after only three years, I50,000 herbarium specimens had been accumulated-and were becoming something of an embarrassment to the Society, not least of all to the Curator and his assistant, in I838, Mr Kellerman, who had the task of preparing labels for between 90,000 and 100,000 specimens for distribution to nearly noo members of the Society.

The Annual Report for I 838 justly praises Kellerman's service to the Society:

The Committee have pleasure in publicly acknowledging the services of Mr Kellerman, the Assistant Curator, who has been engaged since December 
I837, in labelling and arranging the Society's specimens; and in stating their conviction that it is chiefly attributable to his assiduity and exertion that the large mass of plants received, including an accumulation of two years' foreign specimens, were reduced to order, and prepared for distribution. It is with regret that they find that Mr Kellerman's services cannot be continued to the Society beyond the spring of $\mathrm{I} 839$, owing to his intention of proceeding about that time as a collector to South America, under the auspices of His Majesty the King of Saxony; and they take this opportunity of expressing their opinion of his peculiar fitness for such a task, both from the knowledge and information which he has acquired, and the activity and zeal he has uniformly displayed in the cultivation of practical Botany. The Committee have therefore no hesitation in recommending Mr Kellerman to the notice of Botanists, who may be desirous of obtaining specimens from those countries in which it is his intention to collect.

Fortunately Kellerman did not leave the services of the Society in the spring of 1839 . He stayed for another year examining and arranging the large collections in the University Herbarium.

The accommodation of so many specimens also presented a grave problem-and was solved in this fashion. On 3 oth July 1838 , the Society presented a Memorial and Petition to the Patrons of the University of Edinburgh, part of which read:

That the Society have hitherto, by the kindness of the Professor of Botany, been allowed to hold their meetings, which occur monthly, in the Botanical Classroom; and have also been favoured by him with the use of the apartments in the College appropriated to the University Herbarium for the storing of their collections, and for effecting their annual distribution of plants.

That, being now firmly established, the Society are proceeding to classify and arrange their collections, for which purpose they have had an assistant curator, with a salary, constantly employed since the middle of December last; and, from the scale on which their operations are now necessarily carried on, they find that his services will henceforth be permanently required.

That the Society having for their chief object to advance the cause of Botanical science, and thereby promote the public benefit, it has occurred to them that the collections of plants which have from time to time been transmitted to the College, and are now deposited in an unarranged state in the apartments above mentioned, so as to be wholly unavailable for scientific purposes, might, with great advantage to all parties, be handed over to the Society, as well as the permanent use of those appartments, in order that a General Herbarium might be formed, in connection with the University, to which all who cultivate the science of Botany might have ready access for reference and study.

That the Society, if this were granted, would immediately proceed to classify and arrange the joint collections, and would agree that they should become the University Herbarium, of which, however, the Society should continue perpetual curators, but the Professor of Botany for the time to be 
Honorary Curator, with free access to the collection, whether a member of the Society or not.

That, as the plants belonging to the Society already outnumber those belonging to the College, and as much expense must be incurred in their arrangement and preservation, it is hoped the Honourable Patrons will be satisfied that the Society, in making the foregoing proposition, can have no other object in view than that of promoting the science they cultivate, and the general interests of the University where that science is so zealously, ably, and successfully taught.

May it therefore please the Honourable Patrons to take this Memorial into their favourable consideration and accede to the proposal now made on behalf of the Botanical Society, and your petitioners shall ever pray, etc.

In support of the Memorial and Petition, Graham wrote the following letter:

My Lord Provost and Gentlemen, Having read the foregoing petition, I beg to express my anxiety that its prayer should be acceded to. Without some such arrangement, I feel sure that the University Collection will, as from its first beginning in the period of the late Dr Hope, remain utterly useless;with such an arrangement, I feel equally sure that the Collection as it now stands will be made available, and that, before long time, it will form only a small portion of a much greater and very valuable collection, which it is most liberally proposed shall become the property of the University.

This letter and the Petition were favourably received by the Patrons and passed by them to the Senatus for further consideration. The College Committee was appointed, with Graham the Convener, to arrange the terms for carrying into effect the desired union, and on 27 th December 1838 reported:

The College Committee having resumed consideration of this petition, and having communicated on the subject with the Senatus Academicus and with the petitioners, are of opinion that the prayer thereof may be granted by the Magistrates and Council with these explanations and conditions,: viz.

I. That the Society are to have no right of property in the rooms set apart for the University Herbarium, but that these are to be held by them during the pleasure of the Council, and on condition that they shall remove therefrom at any term of Whitsunday, on getting six months previous notice; it being understood, that, in this event, or in the event of the Society removing because of the apartments allotted for them becoming either inadequate or unsuitable, they are to be entitled to take the whole Collections along with them, and also any cabinets, etc. which they have fitted up; but with this proviso always, that in either case the Collections shall continue to be the University Herbarium just as before.

2. That the members of the Senatus shall ex officio have access to the joint collections at all times. 
3. That the Professor of Botany, besides being Honorary Curator, shall be entitled, for the instruction of his Class, to take out from the joint Collections such portions thereof, from time to time, as he shall think necessary, the same being always duly restored; and that the Professor of Materia Medica shall have the same privilege with respect to his Class.

4. That a Report of the state and progress of the Herbarium shall be annually presented to the Senatus and the Town Council, by the Ist day of November.

Of all this the Lord Provost, the Magistrates and Council approved, and thus for the time being the Society's Herbarium was safely accommodated. And so was the Society's Library which by I84I exceeded 500 volumes; since I 839 it had been accommodated in a room in the College, adjoining the Herbarium room, and it was hoped soon to prepare a catalogue of its contents.

Progress on classifying and arranging the General Herbarium, as well as the Library, and the Society's collection of seeds, preserved fruits, fossils, etc, was slow. The work was too much for the spare time of a Curator and until a full-time paid Curator, who should be a competent botanist, could be appointed to devote all his attention to arranging and exhibiting the collections, it was clear that they would never serve the best interests of botanical science. Unfortunately it was necessary to wait until 1890 for real progress to be made; then a Curatorship of the Herbarium and Library was established by Government at a salary of $\mathcal{L}_{\mathrm{I}} 3 \mathrm{O}$ a year, rising by increments to $f_{200}$

With the failing health of Graham, and his death in I845, and with the death or the moving to other parts of the world of some of the Society's original active members, the enthusiasm of the early years abated and fewer herbarium specimens became the property of the Society. Even so, by I85I the 'University Herbarium' had so increased in extent that the University could only conveniently house the British Section. Consequently an arrangement was made with the Office of Works for the foreign collections to be housed at the Royal Botanic Garden and these collections were moved to the Garden in 1863 and were accessible for anyone wishing to consult them. Not so those at the University because the accommodation in which they were housed was badly needed for other purposes-for the Professor of Medical Jurisprudence in fact, Professor Andrew Douglas Maclagan, who at this time was the Society's President. The University Janitor, Cameron, came to the Society's aid and placed at its disposal a room in his house for the herbarium specimens and presses and library. This was only a 
temporary measure, however, for shortly thereafter the collections at the University were also transferred to the Garden, into accommodation which regrettably was totally inadequate-and was to be so for the next 100 years.

For a long period the Society's meetings were held at 5 St Andrew Square, though eventually transferred to the Botanic Garden, and that of 30 th January 1872 was of great significance. Dr Craig had been the Convener of a Committee set up to examine and report on the state of the Society's Library. On 3 oth January he reported that there were upwards of 1,000 books in the Library and that at least one half of them required to be bound. To put the books in order, catalogue them and provide cases for them would, he thought, cost at least $f_{100}$. And he suggested that a committee might be appointed to ascertain whether Government would be disposed to take the Library under its charge and accommodate it in the Herbarium Hall at the Botanic Garden. In furtherance of this suggestion Craig, as Chairman of the Society's Library Committee, wrote to Professor Balfour, Graham's successor, on 23rd April, as follows:

We are authorised by the Botanical Society of Edinburgh, to offer, through you, the Library of the Society to H.M. Board of Works, for the purpose of forming a nucleus of a consulting library for the Herbarium in the Royal Botanic Garden of Edinburgh.

The Library consists of about I,00o volumes, and many of the books are valuable and useful for Herbarium work. You are aware that the Herbarium at the Garden is open to the public, as well as to members of the Society, and many of them consult it. There has, however, been long felt a want of books to consult in the examination of plants.

The Society are aware that you, as Regius Keeper of the Garden, have endeavoured to remedy this defect by granting visitors the use of books from your own private library.

The Society believe that no public collection of dried specimens of plants can be available for scientific purposes without consulting a library. They therefore wish for the sake of the public, and for the advancement of Botanical Science, to do what they can to supply the deficiency.

The Society will hand over to the Government the entire Library, and continue to send any botanical works which they may from time to time receive, on the understanding that the Government will provide for their accommodation and keeping, and that they will be open for consultation to the members of the Botanical Society, as well as to the public who may wish to consult the Herbarium.

The Society have desired us to send this communication to you, with the request that you will forward it to headquarters, with such a statement as you may think necessary to make. The Society believe that by this offer they 
are conferring a great favour on the public-that they are enhancing the value of the Herbarium at the Garden-as well as contributing in no small degrce to the promotion of Botanical Science, and are thus endeavouring to secure for Scotland what England already possesses in the valuable Government Library at Kew.

Professor Balfour sent Craig's letter to the Rt Hon A. J. Ayrton, of H.M. Treasury, with a covering one of his own:

As Regius Keeper of the Edinburgh Botanic Garden, I have received the enclosed letter from the Botanical Society of Edinburgh, and now confirm it, with the request contained in it. I now forward it to you by the Hon. Commissioners of H.M. Works. At the same time I take the liberty of urging strongly the propriety of accepting the generous offer of the Society. I have long been asking for means of providing a consulting library in connection with the Herbarium in the Garden, and it is with great pleasure that I now transmit the Society's offer.

The Library contains many valuable books, which will be most serviceable to those who consult the Herbarium. I have long felt that the usefulness of the collection was much impaired by the want of books.

I hope, therefore, that I shall be authorised to receive the gifts on the part of the Government, and that I may ask a letter to allow uniting the books in the Herbarium Rooms.

I am satisfied as to the value of the Library, and I venture [to suggest?] to you the propriety of accepting it.

On sth June 1872 , at a Council Meeting of the Society at 5 St Andrew Square, Balfour was able to intimate that Mr Ayrton had replied: 'It seems very desirable to carry through the proposal, and I will urge it on the Treasury as soon as I have had the estimate made of the expense.' And after the estimate had been made, on I4th November Balfour reported to the Society that the building of an apartment, adjoining the Herbarium of the Royal Botanic Garden, to accommodate the Society's Library, had now begun.

In this fashion were the Society's Herbarium and Library handed to the Government, an act which was to benefit immensely botanical science not only in Edinburgh but in Scotland and beyond; an act for which the Society can take great pride. Over the years both the Herbarium and Library gradually have been enriched so that today they rank among the finest in the world. But not until I964 were they to be housed in accommodation in keeping with their importance.

From the start the Society issued its publications. At its meeting on I4th April I836, 'A Catalogue of British Plants', prepared by a Committee of the Society, with those plants to be found in the 
neighbourhood of Edinburgh distinguished by conventional marks, was laid upon the table and was ordered to be printed. Regularly the Proceedings of the Society, with brief accounts of the meetings, were published, and the first Annual Report of the work of the Society appeared in 1837. At subsequent annual meetings the President reported on the progress over the year and on the state of botany in Britain, reports which illustrate admirably that the Society was in touch with developments in botany not only in Britain but overseas. And in I844 the first volume of the Society's TRANSACTIONS, covering the years I84I-44, was published.

The early volumes of the TRANSACTIONS show how continuous and close was the relationship between the Society and students attending the botany classes at the University, and how closely its members were in touch with current advances in knowledge of the British flora. It was the practice for the botany classes to hold regular excursions for the study of the plants in the field and throughout the pages of the first dozen volumes of the TRANSACTIONS can be found records of the species observed on such occasions. Likewise can be found the contributions, especially from $1885-1925$, of numerous papers by botanists noted for their work on various aspects of the British flora; Arthur Bennett, R. K. Greville, H. C. Watson, T. Bell Salter, John Bell, T. Townsend, John T. Syme, J. Hutton Balfour, F. Buchanan White, Lauder Lindsay, E. F. Linton, G. C. Druce, A. Scott Elliot, and many another.

Gradually papers on foreign systematic botany began to find their way into the pages of the TRANSACTIONS, especially in Volumes XXII-XXIX which cover the years 1905-25. During this period the enormously rich collections from. Western China of George Forrest were arriving at the Herbarium and their taxonomy was being unravelled by botanists on the University and Garden staffs, as well as by others; such work resulted in papers on Asiatic rhododendrons, primulas, gentians, lilies, conifers and other groups of plants which were to transform the face of the Botanic Garden. The non-flowering plants, the cryptogams-the mosses, the algae, the fungi-both in Britain and overseas, received their fair share of treatment, two papers on these plants occupying two entire volumes of the Transactions; The Distribution of the Hepaticae in Scotland by S. M. Macvicar occupying the whole of Volume Xxv of I9I0, and Richard Spruce's The Hepaticae of South America, the whole of Volume $\mathrm{xV}$ of $\mathrm{I} 88 \mathrm{5}$. In the main it was the cryptogams 
of Scotland which were given greatest attention and this no doubt was inevitable in view of the fact that the Cryptogamic Society of Scotland had been formed in 1874 and was to function as an independent body until 1935 when it was amalgamated with the Botanical Society.

By no means all the activities of the Society have been devoted to the study of systematic botany and the Scottish flora. With the widening horizon of botany, the TRANS ACTIONS have endeavoured to broaden their coverage and, from time to time, papers on anatomy and physiology have appeared and, in more recent years, on ecology, cytology and experimental taxonomy.

The TRANSACTIONS are known throughout the botanical world for they are distributed to 170 scientific institutions and 78 university libraries in 54 countries. In exchange, these establishments send their scientific publications to Edinburgh where they are accommodated on the shelves of the Library at the Botanic Garden. In this way many thousands of pounds' worth of periodicals, over the years, have helped to make this Government Library the finest botanical library in Scotland-at comparatively very little cost to Government.

For many years there existed two very small and select inner circles of the Botanical Society. One was the Botanical Society Club which was almost as old as the Society itself, being formed in I838. On the evening of Thursday, 8th February of that year, there dined with Dr Balfour at his home in Dundas Street several of the original members of the Botanical Society-R. Graham, R. K. Greville, E. Forbes, W. H. Campbell, J. McNab and W. Brand. Balfour explained that his object in asking them was to commemorate the institution of the Society in his home on 8th February I836; that he had formed the idea of calling the twelve original members together on the same evening annually for a like social purpose in order to mark the event. After expressing their obligations to Balfour for the warm interest he had taken in the Society's formation and in particular for the hospitality which they had experienced on the occasions of their numerous meetings at his home, his guests suggested that all twenty-one original members should form a club and that the members should meet in each other's houses annually, at supper, on 8th February. In this fashion the Botanical Society Club came into being, to function for close on a century. And thus it came about that the minutes of the first meeting of the Society are preserved, not in the annals of the 
Society, but among the private papers of the Club. Records of the Club are practically complete from I838-I93I and it is of interest to note that ladies were admitted-as visitors-from as early as I845.

The other inner circle of the Society was the Scottish Alpine Botanical Club. At the Society's meeting in Edinburgh on r2th March I868, Mr Charles Jenner proposed the formation of an 'Alpine Botanists' Club' and, in conformity with his recommendation, 'a committee consisting of Professor Balfour, Mr Gorrie, $\mathrm{Mr}$ Jenner and $\mathrm{Mr} \mathrm{McNab}$ was appointed to consider the subject and to report to next meeting. 'I But the committee never reported. However, on 4th August I 870 several members of the Society took up their headquarters in Mr John Cameron's comfortable hotel at Bridge of Lochay, Killin, Perthshire, and there remained until Thursday, IIth August, botanising on the hills of the district and collecting alpine plants for the Edinburgh Botanic Garden. On the evening of Wednesday, Ioth August, their last night in the Lochay Hotel, the Scottish Alpine Botanical Club was formed 'to consist of naturalists who are in the habit of visiting Alpine districts of Scotland for the practical study of science, and who have proved themselves to be pleasant compagnons de voyage. No one is to be admitted who has not these qualities, and who has not proved that he has ascended on foot to the summits of three Scottish Mountains, not less than 3,300 feet above the level of the sea.'2 Among the ten original members were Professor J. Hutton Balfour and three others who were to figure prominently in the history of the Botanic Garden-Professor Dickson, Isaac Bayley Balfour and John Sadler. Throughout its long life of nearly ninety years the members of the Club met at least once annually for an excursion of several days' duration to the mountains of Scotland, with an occasional visit elsewhere in Britain-or even overseas. These meetings were reported and printed regularly in the TRANS ACTIONS of the Botanical Society and have added considerably to our knowledge of Scottish botany. By 1957 the Club had almost ceased to function and its activities were taken over by the formation of an Alpine Section of the Botanical Society whose excursions are open to all Society members and are reported in the Society's publication.

I Minutes of Scottish Alpine Botanical Club.

2 ibid. 
During its long history financial difficulties have occasionally arisen but from time to time more than one benefactor has come to the Society's assistance.

In recent years the meetings of the Botanical Society have spread far beyond the confines of Edinburgh in that periodic meetings are held annually in Glasgow, St Andrews, Dundee, Aberdeen and Inverness, and, moreover, every year, in one or other of the University Departments of Botany in Scotland, a symposium is organised at which current research problems are discussed. The activities of the Society have never before been pursued so energetically and on so broad a basis as today. 


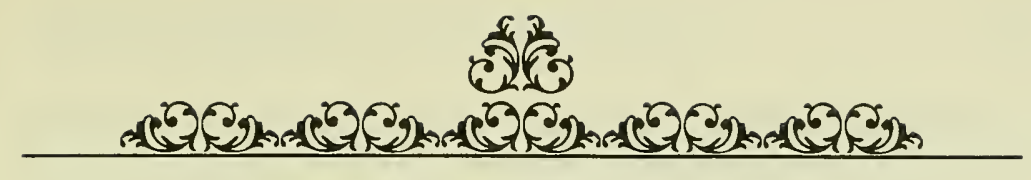

\section{CHAPTER ELEVEN}

\section{John Hutton Balfour}

DURING HIS LAST MONTHS IN OFFICE PROFESSOR GRAHAM was assisted by Dr Joseph Dalton Hooker who in I839 had accompanied the intrepid Captain James Clark Ross on the voyage of the EREBUS to the Antarctic, and who at the time of Graham's death was engrossed in the writing of his FLORA ANTARCTICA. Hooker's motives in assisting Graham were several; he had a genuine desire to come to the ailing Graham's aid, he was anxious to earn some money, and he had an eye on Graham's Chair. In October I844 he wrote to his friend William Henry Harvey, the Irish botanist, to the effect that he was

.... getting very anxious to do something that will pay me-on dit that poor Dr Graham of Edinboro' is on his last legs, and my friends want me, should he go off the hook (which I from my heart say heaven forefend), to stand for the Chair of Botany there (don't laugh). I suppose you like my impudence. I should not be sanguine, as the opposition would be very strong, and if Forbes ${ }^{I}$ stands he will be by far the most eligible: I have no great notion of lecturing but I must pick up a livelihood somehow. How I shall quaque at my first lecture. You must not say anything about this, at present, visionary subject.

Financially, in his assistance to Graham, Hooker was to be disappointed; there was no question of his being paid and Graham apparently was in such financial difficulties that he could not reimburse Hooker from his own resources. Even so, on Graham's death, Mrs Graham sent Hooker froo begging him to accept it for his 'great services'. Primarily Hooker lectured for Graham because 'there would appear to be no doubt of my future success when a candidate for the Chair', as he wrote to his grandfather, the eminent Dawson Turner.

Edward Forbes, at that time Professor of Botany at King's College, London. 
The lectures began on sth May I845 and very soon Hooker was 'lecturing away like a house on fire' and able to 'spout an hour of gas without notes even'. The summer term quickly passed and at the beginning of August Hooker was back home-though for a few days only. On 7th August Graham died and Hooker returned to Edinburgh to canvas the Town Council. In the meantime Hooker's father, Sir William, canvassed the Home Secretary, Sir James Graham, and many others, to the extent that by the middle of September Joseph had a hundred testimonials in support of his candidature for Graham's vacant Chair. They were to avail him nothing, however, for the appointment went to the Edinburghborn John Hutton Balfour who, at the time, was Professor of Botany in the University of Glasgow.

At a meeting of Edinburgh Town Council on 7 th October, the candidatures of Balfour and Hooker were considered. The Lord Provost was in the chair and spoke at considerable length:

The duty that devolves on me today is the most painful that I have had to discharge since I had the honour to sit in this Chair. There are now, we may say, but two candidates for your consideration. One of them has been, from his boyhood, my own friend, and I hope, to grey hairs, he will continue to be so; and such are the amiable dispositions and excellent qualities of this young gentleman, that he has secured to himself the respect and attachment of all who know him. Under these circumstances I do feel it exceedingly painful to be obliged-I hope you will recollect not in opposition to that gentleman-from a conscientious consideration of the qualifications of the two candidates now before us, to propose for your suffrages the other candidate (Dr Hooker), whom I never knew, nor never saw, till a few days ago.

After emphasising that neither he nor any of his colleagues on the Town Council must allow personal feelings to weigh with them he stated that he had examined the testimonials of both candidates with the greatest care;

.... and I have with the greatest anxiety, endeavoured to find out who it is that has the suffrages of the men of science in that walk for which we are now to appoint; and I must say, if ever I saw evidence which was strong, uncompromising, and most decided, it is that in favour of Dr Hooker. The evidence before me, under all circumstances, compels me to say that this is the man who stands highest in reputation among the scientific men of Great Britain, and of the world .... In the one case we have testimonials from literary and clerical men; but in the case of Dr Hooker we have testimonials from nearly all the professors in the universities of Europe. 
Thus did the Lord Provost extol the claims of Hooker and finally begged to move that Hooker be elected Professor of Botany. His motion wás seconded by Bailie Mack.

Bailie Duncan spoke on behalf of Balfour. Whilst none could deny the great scientific achievements of Hooker, Duncan, from the evidence of the testimonials, found him lacking in knowledge of physiological botany, a branch of botany which some of the writers of the testimonials regarded as of much importance; Balfour on the other hand offered 'evidence of indisputable excellence in this department of the Science'. Balfour had proved himself both an excellent lecturer and Professor of Botany in the University of Glasgow, and moreover had extensive and intimate acquaintance with the application of botany to medicine and the arts-a necessary qualification for the Edinburgh Chair. Duncan's concluding remark that 'I have no doubt that botanical science, and the school of medicine-standing so high as it does-will be both greatly advanced by the election of Dr Balfour' was greeted with applause.

The comments of Bailie Gray, who seconded Duncan's motion, were received with laughter. He stated that the impression which the reading of Hooker's testimonials had left on his mind was that they had been given in compliment to Hooker's father; some had even said that the name of Hooker was sufficient to carry the Chair. Now, there might be something in a name, but there was certainly not enough to induce him to elect a son because of the qualifications of the father. He believed that his appointment to the Antarctic Expedition had been given solely because he was the son of Sir William Hooker. He had no doubt that Dr Hooker had performed the duty well enough; but it was easy to swim when the head was held up. He was sure that if Dr Balfour had been appointed to that expedition he would have performed that duty equally well.

After the Dean of Guild and various others had spoken, the Council then divided; 23 voted for Balfour and Io for Hooker. Little did this Council realise how momentous a decision it had taken and how it was to influence the cause of botany not only in Edinburgh, but in Britain and beyond.

Although Balfour was appointed by the Town Council to the Professorship of Medicine and Botany in October I845 it was not until the following month that the Crown offered him the posts of Regius Professor of Botany in the University, Keeper of the Garden and Queen's Botanist-after they had been first offered to 
Joseph Hooker. Balfour refused to accept the Town Council appointments if he could not also have those of the Crown.

Balfour (Plate vc) was to hold the Edinburgh Chair of Botany and direct the fortunes of the Botanic Garden for 34 years-until his retirement in I879. His career has been admirably summarised by his distinguished son, Isaac Bayley Balfour, in F. W. Oliver's MAKERS OF BRITISH BOTANY (I9I3). ${ }^{\text {r }}$

John Hutton Balfour, who succeeded Graham, was born in Edinburgh Isth September I808. The eldest son of Andrew Balfour, surgeon in the Army, who afterwards settled in Edinburgh as printer and publisher, in which business his enterprise was adequate to the venture of the EDINBURGH ENCYCLOPAEDIA under the editorship of (Sir) David Brewster. Andrew Balfour was a grim old presbyterian of the stuff covenanters were made, and in the strict home environment which he created young Balfour early came into touch with theological dogma. The echo of these early impressions remained with him throughout life.

Educated at the High School of Edinburgh where he laid the foundation of sound classical scholarship-always his unobtrusive distinction-Balfour entered the curriculum for the Arts degree at the University. Before completing this he migrated to St. Andrews in order to be under the influence of Professor Thomas Chalmers-the famous Divine, afterwards leader in the disruption that founded the Free Church of Scotland-in conformity with the desire of his father that he should become a minister in the Church of Scotland. But Divinity did not claim him and he returned to Edinburgh to begin the study of Medicine-a decision in face of family pressure which is tribute to the strength of purpose which characterised him and found expression frequently in after life.

At the beginning of this renewed Edinburgh curriculum Balfour attended the Botany course of Professor Graham in 1825, and obtained his first scientific instruction in Botany-a subject for which he had always shown fondness. Robert Dickson, afterwards Lecturer on Botany at St. George's Hospital, London, was a fellow-student, and together they, in this and following years, made many botanical excursions about Edinburgh. With his fellows Balfour seems to have been bon camarade, acquired all the ephemeral distinction attaching to a facile writer of rhymed couplets for occasions, and as an inveterate maker of puns was in demand for the office of punster at the convivial clubs of the period. ${ }^{2}$ A mark of more serious attainment-he was President of the Royal Medical Society in two years. After graduation as MD, when he also became a fellow of the Royal College of

I The following paragraphs are quoted from Oliver's work by the kind permission of the Cambridge University Press.

2 Authors' note. He was for example one of the founder members of the Bonaly Friday Club, an institution formed in 1842 by the sons of Lord Cockburn in imitation of the sedate Friday Club their father had helped to found in 1803 . Exuberance was the keynote of their proceedings at the twice-yearly meeting at Bonaly Tower and Balfour held the office of punster. 


\section{PLATE V}

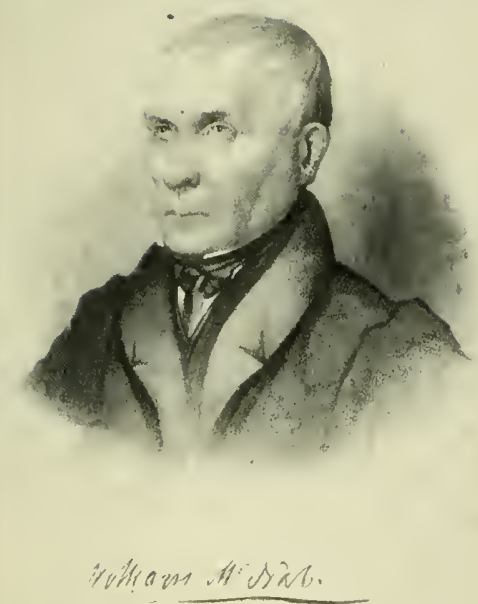

(a) William McNab (I780-I 848)

Curator of the Garden $1810-1838$

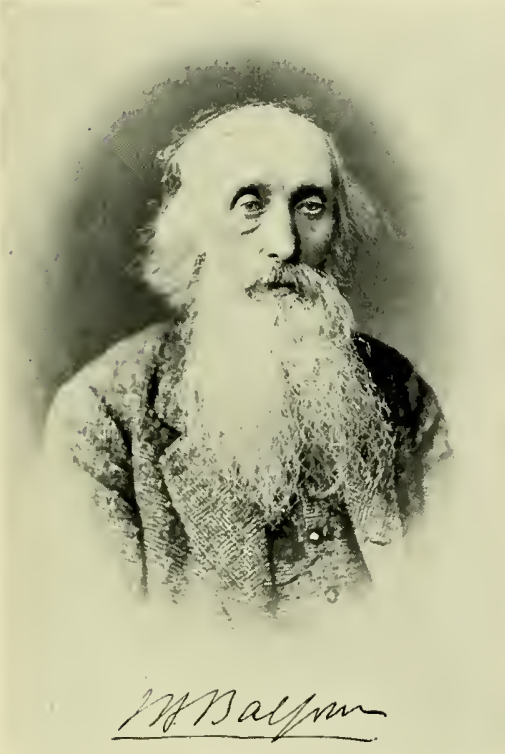

(c) John Hutton Balfour (I 808-I 884) Regius Keeper and Queen's Botanist 1845-1 879

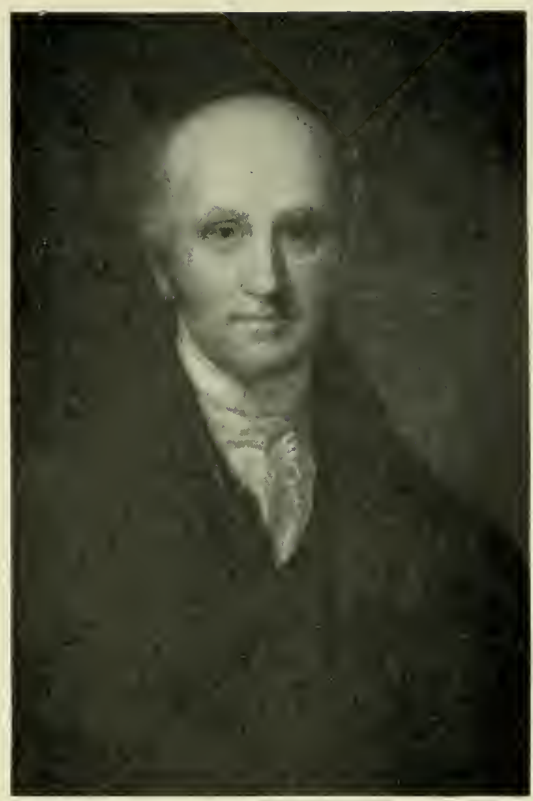

(b) Robert Graham (I 786-I 845) Regius Keeper and King's, later Queen's, Botanist I 819-I 845

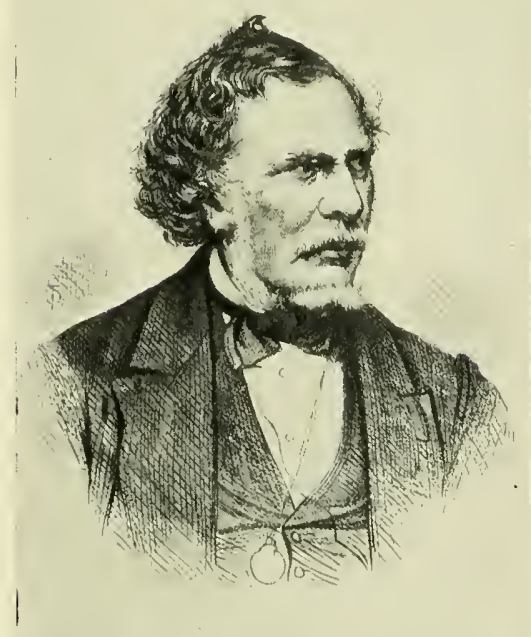

(d) James $\mathrm{McNab}$ ( $1810-1878)$ Curator I $849-\mathbf{I} 878$ 


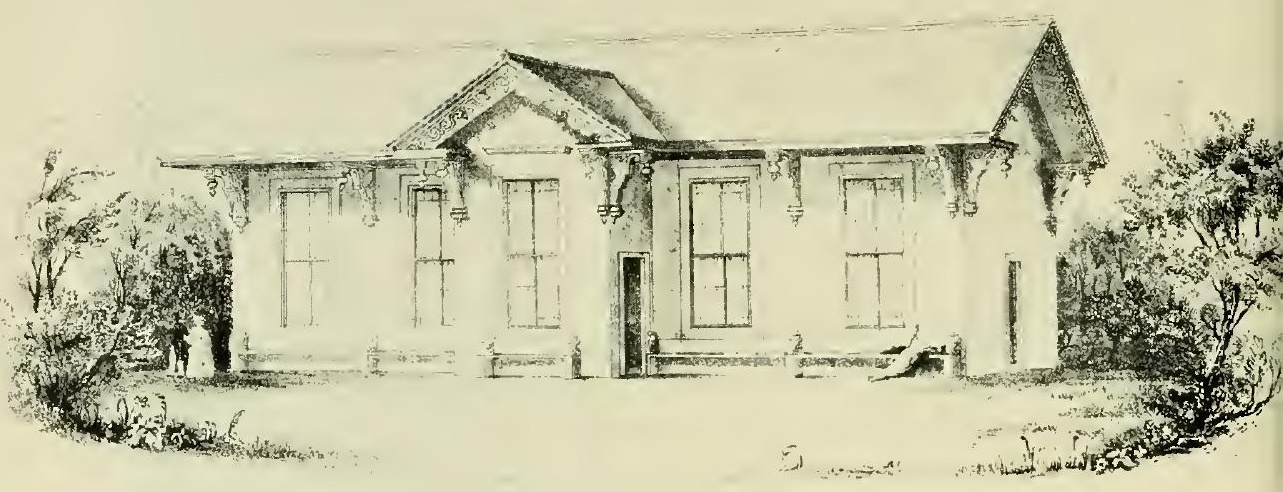

(a) The Exhibition Hall of the Royal Caledonian Horticultural Society which served as the Herbarium of the Botanic Garden I 864-1964

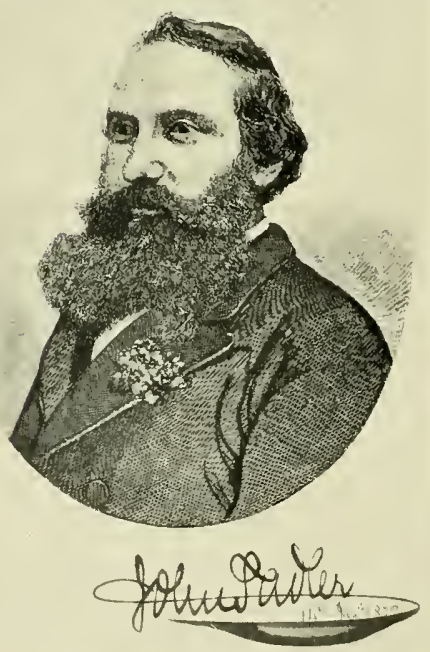

(b) John Sadler (1 $837-1882)$

Curator I879-1882

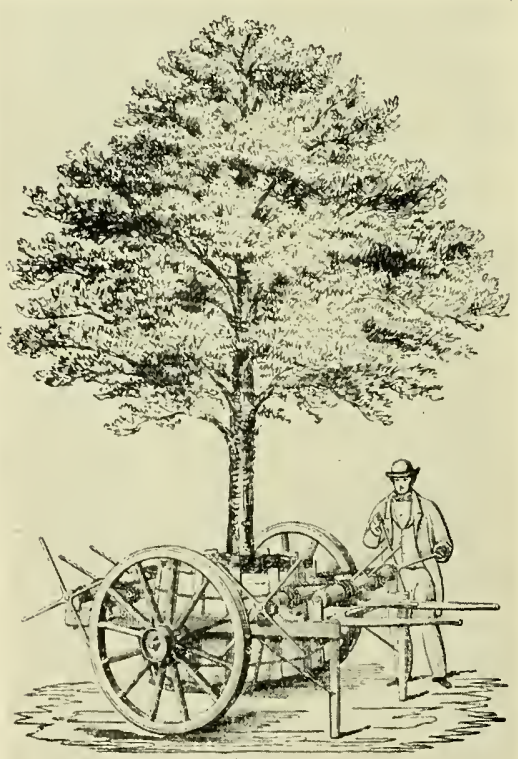

(c) The planting machine, originally invented by William McNab and modified by James McNab 
Surgeons in Edinburgh-his thesis for the former being 'De Strychnia', for the latter 'On Purulent Wounds'-Balfour went in $\mathbf{1} 832$ to Paris to continue his medical education, studying there under Dupuytren, Lisfranc, and Manec. Returning, he settled in Edinburgh in 1834 and entered on practice, becoming assistant within and without the University to Sir George Ballingall, Professor of Military Surgery. Amongst his patients he numbered De Quincey and his family. De Quincey's eldest son died from a cerebral complaint, and the autopsy revealed an interesting pathological condition which formed the subject of Balfour's investigation, and an account of it his first published scientific paper.

From the claims of Medicine Balfour could wrest little time for botanical pursuits, but his holiday always meant the botanical exploration of some area, preferably alpine, and his home became a centre for men of kindred tastes. There in co-operation with his old teacher Graham, and with Greville, Forbes, Falconer, Parnell, Munby and others, was instituted in I836 the Botanical Society of Edinburgh, with wide aims for the promotion of Botany-amongst them the creation of a botanical library and a herbarium. This has proved a signal service to science. It was the pegging out of a claim which has been made effective. The Society after a life-as with all such societies-of fluctuating periods of greater and lesser activity, flourishes still, and its library and herbarium, transferred to the Crown when the space demand of their bulk became urgent, have been the foundation for the large botanical library and herbarium now maintained and subsidised by Government in the Royal Botanic Garden.

Plants gradually drew Balfour away from patients and in 1840 he carried the divorce so far as to establish himself as a teacher of Botany in the Extramural Medical School in Edinburgh-that exemplar of free-trade in teaching -from which so many of the famous occupants of Chairs in the University have entered its portals. But only in I84I, when Sir William Hooker moved to Kew and a vacancy was then caused in the Glasgow Chair of Botany to which Balfour was elected, was he able to give up medical practice entirely.

In Glasgow the first years of Balfour's botanical career were spent, but they were few. On the death of Graham he returned to Edinburgh as Professor of Medicine and Botany and Keeper of the Royal Botanic Garden - the electors passing over Joseph Dalton Hooker also a candidate. In the sphere of these offices the rest of his active life was passed until his retirement in 1879. He came to the University of Edinburgh at a time when the reputation of its medical school was upheld by a remarkable band of teachers in the Medical Faculty-Allen Thomson, Alison, Christison, Goodsir, Gregory, Jameson, Simpson, Syme-and when the struggle of the University after a revised constitution was approaching the climax reached in 1858 , when with other Scottish Universities Edinburgh obtained autonomy, and science was enfranchised. Of this Faculty he became Dean, and held office until close upon the time when he became Emeritus. In all the discussions and controversies, destructive and constructive, that attached to so weighty a crisis, Balfour's influence and outlook for science were used with effect, and no less influential were his action and advice in subsequent years when the specific question of medical reform was raised, as it so often was. 
Absorbing administrative work of this kind, to which were soon added the duties of a Secretary of the Royal Society of Edinburgh-(and he remained in the Secretariat to the end of his active life)-as well as those of an editor of the EDINBURGH NBW PHILOSOPHICAL JOURNAL-(afterwards merged in the ANNALS AND MAGAZINE OF NATURAL HISTORY)-of Secretary of the Royal Caledonian Horticultural Society and of other offices, made inroad alike upon time and energy of a man who had also the administration of the Royal Botanic Garden in his hands, as well as the calls of his Professorship of Botany to attend to. But Balfour was untiring in industry, prompt and precise in method, and administrative work appealed to him.

Though liable like his predecessors to undertake clinical medical teaching, Balfour, save for occasionally acting as locum tenens, took no share in it, and his energies in teaching were devoted to Botany. On the lines he followed he was pioneer. We have seen that Field Botany had been for several decades a characteristic of the Edinburgh Botanic School. Whilst maintaining this feature, Balfour added laboratory work. The word 'laboratory' was not then in vogue, and 'microscopical room' was the designation of the new domain in which the 'guillotine', not the 'microtome', was used. In the sphere of practical teaching this was a notable advance, and the more so when the technical difficulties that had to be overcome are remembered-the days of cheap microscopes were but beginning, aniline dyes were not yet. Nevertheless the student of the time had opportunity were he so minded of examining plant-form and plant-structure for himself under direction, and if the equipment for work were not so perfect mechanically as modern methods now permit of, the training in minute observation was no less excellent than that of to-day, and the educational effect of the teaching no less valuable. The scheme of work was that of the text-books-passing progressively from tissues to organs vegetative and reproductive both phanerogamic and cryptogamic

Before he was able to establish, as he did in the early fifties, practical laboratory classes, Balfour had introduced a system of demonstrations of microscopic objects and of physiological experiments in illustration daily of the subject of his lecture, and it is testimony to his power of infusing zeal in pupils that there was always a contingent of them ready to come to the Botanic Garden at six o'clock in the morning to give voluntary aid in the arranging of these demonstrations for the lecture at eight o'clock. Many of those who came have recorded that they found that period and its work one of the most inspiring in their student history.

This new departure in teaching did not interfere with the continuation and extension of field-work, which up to this time had been the form of practical study cultivated in Edinburgh. On the contrary the Botanical Excursions gave Balfour an outlet for energy and favourable opportunity for the exercise of those gifts of personal magnetism and intellectual stimulus through which he influenced and guided many generations of students. Every Saturday during the summer session an excursion was made, and one of some days' duration usually brought the session to a close. Through these excursions the greater part of Scotland was traversed-on one occasion the terminal 
excursion of the session was to Switzerland-and the features of flora and vegetation were brought to the attention of many hundreds of students.

The aim and result of the excursion were not solely the acquisition of plants and their identification. The stimulating effect on many of this side of Botany is evidenced even in our day by the zeal with which search after rare plants is pursued, and in the eagerness displayed in the race after microforms. But the enticement of acquisition and discovery of novelty whilst there were not the governing influences in Balfour's excursion. In touch as he was with the problems of organography in its fullest sense, a man of wide reading familiar with the botanical work of his time, and associated as he had been in the field with men like Edward Forbes and Hewett Cottrell Watson, Balfour could and did look at plants from the standpoint of their place in vegetation, and in relation to the conditions of growth, and as having a history in their habitat. His teaching reflected this. It was never classification, diagnosis, and nomenclature as the end-all of Botany. The details emphasised changed as the progress of botanical discovery gave new clues to explanation of form and relation, and it was the solvings and attempts at solvings of observed phenomena that gave that fascination to his excursions, the remembrance of which seems to have clung to those who had the fortune to join them. The succession of plants and plant-form from base to summit of a highland hill; contrasts of vegetation of stream-course, mountain pasture, alpine rock; high mountain forms of shore plants; intrusion and extirpation; factors of distribution and their influence; - those and other problems of what we now term Ecological Botany were themes on which the Professor discoursed in his rambles, filling the pupil with information and forcing him to think out to such conclusion as he might on the evidence before him. And then the whole occasion was so enlivened by the outgo of good humour and mirth in joke and pun and story, that fatigue and weariness, which the physical exercise might evoke in those less attuned than the wiry Professor, were drowned in the sunny current of humanity.

I mention this practical teaching first, for it was the characteristic feature, but the idea of practical illustration pervaded all Balfour's effort. His lecture table became a synopsis of the lecture-living plants, herbarium material, museum specimens, all were pressed into service to elucidate the points of the discourse, whilst the walls were tapestried by diagrams. Never did teacher more sedulously absorb the new for presentation to his pupils. $\mathrm{He}$ was a lucid expositor, and, apart from his University lectures, during many years was sought after for more popular discourses to non-academic audiences.

The period of Balfour's teaching included the momentous year I859. The impulse of the new spirit introduced by Darwin did not stimulate Balfour as it might have done a younger man. His religious beliefs-always in evidence -were showing then the influence of his early environment, and whilst Darwin's work was incorporated in his teaching, the acceptance of Darwin's theory appeared too near the negation of faith. On Balfour indeed, as on others with like views, the immediate effect of the Origin was the opposite of vivifying. It gave a shock. And this, I conceive, not so much a consequence of Darwin's own statement of his theory as of the forceful uncompromising attitude of the chief protagonist of his cause. Arrogance there was on the 
religious side, but no less also on the scientific side in the discussion. Perhaps it was well that the contest was sharp and bitter. It ended sooner, but its course was strewn with misconceptions and with confusion of cause and effect. In our days of complete reconciliation, when every tyro lisps in phyletic numbers as the outcome of Darwin's work, it is not amiss to recall the struggle at its inception-lest we forget.

The system of Essays which formed so important a part in Graham's teaching remained as prominent and was even developed further in Balfour's course in a way which had the inestimable merit of making the student feel that his study of plants had a living relationship with the everyday concerns of life. Thus when Simpson was engaged in his epoch-making investigations on anaesthetics, the subject for an essay was the effect of anaesthetics on sensitive plants, and by way of emphasis, the prize awarded was a gift by Simpson himself. Similarly Balfour enlisted the sympathy of Messrs Lawson, the prominent agricultural nurserymen of the day, and their prizes for dissection of grasses, for kinds of cereals, and like subjects, were constant reminders of the relations of botanical study to agriculture. The subjects of essays covered a wide field. The titles-influence of narcotic and irritant gases, changes which have taken place in the Flora of Britain during the historical era, cytogenesis and cell development, phanerogamous embryology, cryptogamous reproduction, teratology-may serve to indicate this, and an essential was always the practical illustration, microscopic or other.

For the use of the students Balfour compiled text-books which, like his lectures, are comprehensive in the field they cover, and encyclopaedic in the information they convey. His facile pen found expression too in numberless articles in encyclopaedias and magazines, and his activity as an expositor of botanical topics of the time was unbounded.

In the Botanic Garden Balfour obtained the material for the definite contributions he made to natural knowledge which are in the domain of Systematic Botany. No work in which Balfour engaged gave him more genuine pleasure that the administration of the Botanic Garden. Entering on the responsibility of its care when its repute was high, he left it on laying down office in even higher reputation, for in the McNabs-William and James-father and son-he had lieutenants of the first rank in gardening. During his regime the equipment for laboratory teaching to which reference has been made was installed, a museum to which old pupils all over the world contributed was instituted, and the Garden itself trebled in size, the latest addition, made just before his retirement, being an area to be cultivated as an arboretum for students of Forestry-a subject then beginning to claim attention.

With Balfour's retirement in I879 the link of Botany with Medicine in the University was still further weakened. Medicine was left out of the title of the Chair to which Alexander Dickson succeeded.

Such was the man who was to work unsparingly on behalf of his students, the Scottish flora, and the Royal Botanic Garden, for more than 30 years. The picture is not quite complete, however. Balfour's character is best illustrated in the accounts he wrote of 
the excursions he made with his students and friends into the mountains of Scotland. Some of these accounts are quite remarkable not only for the number of alpine plants which were recorded but for the picture they give of the temperament and attitude of mind to the job in hand of these remarkable men. For instance, in the EDINBURGH NEW PHILOSOPHICAL JOURNAL for July I 848 , Balfour prefaces his account of a three-weeks' excursion in 1847 , to the richest alpine districts in Britain-the mountains of Braemar, Glen Isla, Clova, and Ben Lawers-with these remarks:

Excursions may be truly said to be the life of the botanist. They enable him to study the science practically, by the examination of plants in their living state, and in their native localities; they impress upon the mind the structural and physiological lessons he has received; they exhibit to him the geographical range of species, both as regards latitude and altitude; and with the pursuit of scientific knowledge, they combine that healthful and spirit-stirring recreation which tends materially to aid mental efforts. The companionship too of those who are prosecuting with zeal and enthusiasm the same path of science, is not the least delightful feature of such excursions. The various phases of character exhibited, the pleasing incidents that diversified the walk, the jokes that passed, and even the very mishaps or annoyances that occurred-all become objects of interest, and unite the members of the party by ties of no ordinary kind. And the feelings thus excited are by no means of an evanescent or fleeting nature; they last during life, and are always recalled by the sight of the specimens which were collected. These apparently insignificant remnants of vegetation recall many a tale of adventure, and are associated with the delightful recollection of many a friend. It is not indeed a matter of surprise that those who have lived and walked for weeks together in a Highland ramble, who have met in sunshine and in tempest, who have climbed together the misty summits, and have slept in the miserable sheiling - should have such scenes indelibly impressed on their memory. There is, moreover, something peculiarly attractive in the collecting of alpine plants. Their comparative rarity, the localities in which they grow, and frequently their beautiful hues, conspire in shedding around them a halo of interest far exceeding that connected with lowland productions. The alpine Veronica displaying its lovely blue corolla on the verge of dissolving snows; the Forget-me-not of the mountain summit, whose tints far excel those of its namesake of the brooks; the Woodsia with its tufted fronds adorning the clefts of the rocks; the snowy Gentian concealing its eye of blue in the ledges of the steep crags; the alpine Astragalus enlivening the turf with its purple clusters; the Lychnis [i.e. Viscaria] choosing the stony and dry knoll for the evolution of its pink petals; the Sonchus raising its stately stalk and azure heads in spots which try the enthusiasm of the adventurous collector; the pale-flowered Oxytropis confuning itself to a single British cliff; the Azalea forming a carpet of the richest crimson; the Saxifrages with their white, yellow, and pink blossoms clothing the sides of the streams; the Saussurea and Erigeron crowning the rocks with their purple and pink capitula; the 
pendent Cinquefoil blending its yellow flowers with the white of the alpine Cerastiums and the bright blue of the stony Veronica; the stemless Silene giving a pink and velvety covering to the decomposing granite; the yellow Hieracia whose varied transition forms have furnished such a fertile cause of dispute among botanists; the slender and delicate grasses, the chickweeds, the Carices, and the rushes, which spring up on the moist alpine summits; the graceful ferns, the tiny mosses, with their urn-like thecae, the crustaceous dry lichens with their spore-bearing apothecia, all these add such a charm to Highland botany as to throw a comparative shade over the vegetation of the plains.

The most outstanding of these 'mishaps or annoyances' occurred in this same year of 1847 , when Balfour and his party, accused of trespassing, had a skirmish with the Duke of Atholl and his retainers. A law suit followed and the notorious 'Battle o' Glen 'Tilt' was celebrated in verse and pictures.

During his first three years in office, Balfour had the loyal assistance of his old friend and Principal Gardener William McNab, who in I844, at a Testimonial Dinner, had been presented with a snuff-box purchased from a fund, exceeding $f_{1500}$, which had been contributed by upwards of 800 people of all ranks who equally esteemed his personal character and appreciated the services he had rendered to horticultural science. The Testimonial stated:

During his whole career $\mathrm{Mr} \mathrm{McNab}$ has pursued a steady and unobtrusive course of observation and experiment, with regard to the rearing of Exotics from all quarters of the globe; and that he has been pre-eminently successful in this department, the Botanic Garden, in its present state, furnishes ample proof. He has also, by useful publications (particularly those on the cultivation of Cape Heaths, and the Transplanting of Evergreens), made known to others both the nature and results of his practice; and his numerous pupils have not failed to disseminate widely the lessons they were taught. Indeed, by the strict order and undeviating regularity which he has ever both displayed and enforced, $\mathrm{Mr} \mathrm{McNab}$ may be said to have organised a new school of Practical Gardeners; while his kindly encouragement of merit, wherever it appeared among his assistants, and his unwearied attention to every request for advice or aid, whether from operative or amateur Horticulturists, has made him as universally esteemed as he is extensively known.

The character and philosophy of this great gardener were admirably illustrated by his remarks on receiving his presentation:

Gentlemen, you can easily conceive what my feelings must be, and how unable I am to give expression to them .... Fain would I give utterance to the emotions of this moment, but it is quite out of my power to do so. I have never been trained to public speaking, and to make the matter worse, 
I have little voice left; but even if I were still possessed of the same powerful organ I once enjoyed, I could not have said anything, for the moment I begin to hear the sound of my own voice, everything flies out of my head ... I I . . . have never been able to see that I have done more than my duty. It is true that I know the names of a great many different plants, and also how to cultivate them, so as to make them thrive in this climate; but yet I have never learned this-how to distinguish a species from a variety, nor how to tell what makes a genus. It is very true there is a plant which has been named after me; but this did not take place from any merit of mine as a Botanist .... Besides, even if my education and talents had fitted me to be a Botanist, I feel I could not have entered on that field without treading on ground belonging to my superiors-which is an interference that no good subject ought to be guilty of. For the past forty-three years I have had a considerable deal to do in recommending persons to situations of responsibility, both as head gardeners and as under-gardeners. And my invariable advice to them has been, first to serve their employers well and faithfully, as being the best way to serve themselves; and in the event of their not being able to please, to leave the situation as soon as possible, and on such terms as would still retain them the good feeling and friendship of their employers. I have been told that every master whom I have served during the last forty-eight years, who is still in life, has his name inscribed in the list of contributions to the splendid Testimonial now presented to me; and from this circumstance I flatter myself that I have acted on the advice which I have given to others. I am afraid to say more, but would willingly address a few words to my younger brethren on a point which my experience has given me some means of forming a judgment upon. We are all aware of the prodigious improvements which have, within these few years, taken place in every sphere of knowledge and business. The art of gardening has not stood still, but has progressed also at railway speed, and now we have a vast number of publications constantly issuing from the press for the instruction both of the scientific and practical gardener. It is said that this knowledge will enable the rising gardeners to excel their predecessors, and also save them a great deal of the toil and study formerly required. I warn my younger brethren against being misled by such ideas. Theory is all very well; but I can assure my young friends that they can never rise to distinction without studying as diligently, and working as hard, as we have done. We have now a considerable amount of knowledge as to the nature and properties of soils and manures, and of our varying climate; but notwithstanding the numerous weather prophets and almanac makers of our time, I never yet met with a man who could tell me, with certainty, what sort of a day we were to have tomorrow, or even in the course of a few hours....

Four years after receiving his Testimonial, William $\mathrm{McNab}$ died on Ist December 1848 and was succeeded as Principal Gardener by his eldest son James, who was born in April 1810 at Richmond, Surrey, during the time his father was foreman in Kew Gardens. In the same year the family moved to Edinburgh where father 
William was appointed Principal Gardener at the Royal Botanic Garden. On leaving school, and determined to follow his father's profession, for twelve years James was employed in the Botanic Garden, first as an apprentice, next as a journeyman, and finally as a foreman. He was to prove himself as great a gardener as his father and during these early years conducted a series of experiments on the heating of glasshouses by means of steam and hot water pipes, as well as designed gardens, all of which was to prove to be invaluable to him in later life. Moreover he possessed one accomplishment denied his father; he was an excellent draftsman and made drawings of noteworthy flowering plants which from time to time were published in Sweet's FLOWER GARDEN, the BOTANICAL MAGAZINE, and other periodicals. Naturally his father's friends were his friends, and one such was Robert Brown the Perthshire nurseryman who had discovered Phyllodoce caerulea, the low growing heath-like evergreen shrub with purple urn-shaped flowers, near Aviemore, in I8I2. In I834, Brown, having retired from business and anxious to see for himself, growing in nature, the American forest trees and shrubs to the rearing of which, in his Perthshire nursery, he had devoted so much of his life, decided to pay a private visit to North America and Canada and to ask his friend James $\mathrm{McNab}$ to accompany him. McNab accepted the invitation and, on his return, published in the EDINBURGH NEW PHILOSOPHICAL JOURNAL for I 835 an account of the rarer plants the two friends had observed on their travels. Of his journey he maintained a journal, extracts from which, in later years, he was to read before the Botanical Society of Edinburgh, of which, with his father, he was one of the original members on its foundation in 1836 .

McNab's experiences in Canada and North America were to prove useful some years later when another Edinburgh collector was despatched to N.W. America. On 22nd November 1849, at the Royal Botanic Garden, there was held a 'Mecting of Gentlemen interested in the promotion of the Arboriculture and Horticulture of Scotland'. Professor Balfour was in the chair, James McNab was in attendance, and it was agreed to form an association, with the name of the Oregon Association, with the object of sending a collector to the Pacific West Coast of America to collect, chiefly, seeds of conifers. John Jeffrey from Fife was the young collector chosen. He was employed in the Botanic Garden, had attracted the attention of $\mathrm{McNab}$ by volunteering to ascend a high tree to remove 
a branch which had been broken by the wind and by winning the prize offered to practical gardeners for the best collection of dried plants made in the neighbourhood of Edinburgh. He was recommended to the Association by both $\mathrm{McNab}$ and Balfour and in June 1850 he left for York Factory in Hudson's Bay and accompanied the Company's 'despatch brigade' across the continent in the following winter. By the spring of $\mathrm{I} 85 \mathrm{I}$ he was on the Pacific Coast in the Mount Baker region, sending home seeds of Tsuga mertensiana the Mountain Hemlock, Psendotsuga menziesii the Douglas Fir, Picea sitchensis the Sitka Spruce, Abies lowiana the White Fir, and Pinus contorta the Beach Pine. In I852 he journeyed further south, doubtless along the Willamette River, the route taken by David Douglas 27 years earlier, reached the Siskiyou Mountains which divide S. Oregon from California, and further explored the forests on the flanks of Mount Shasta. He sent home seeds of Tsuga heterophylla the Western Hemlock, Abies procera the Noble Fir, $A$. amabilis the Red Silver Fir, Pinus contorta var. latifolia the Lodgepole Pine, $P$. balfouriana, and the pine which Dr Greville named after him, $P$. jeffreyi, which, no matter whether it be given specific rank or regarded as a form of the widely distributed $P$. ponderosa, is a fine monument to the name of the young collector who, in the following year, disappeared in San Francisco and was never heard of again. Time has shown that his most important introduction was, of course, the Western Hemlock. 


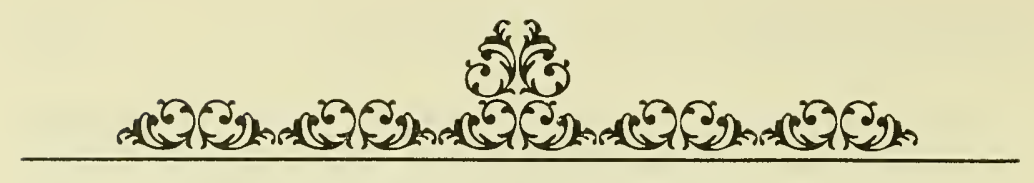

\section{CHAPTER TWELVE}

\section{J. H. Balfour, James McNab and John Sadler}

JAMES MCNAB's (PLATE Vd) APPOINTMENT TO THE BOTANIC Garden in I849, according to the EDINBURGH EVENING COURANT, was hailed 'with feelings of unmingled satisfaction. On his father's death all eyes were turned on him, not merely as the legitimate, but as the best and highest qualified successor.' Of course he knew the Garden well for during the past twelve years he had been Curator of the Garden adjacent to the Botanic Garden-the Garden of the Royal Caledonian Horticultural Society. This Society had been formed in I809, five years after the Horticultural Society of London. On 25th November of that year, the Edinburgh nurseryman Thomas Dickson had called a few friends to his house to discuss the possibilities of forming a Horticultural Society in Scotland. The friends called a general meeting of professional and amateur gardeners to the Physicians' Hall, George Street, on sth December. This hall has long since disappeared and the National Commercial Bank now stands on the site. At this meeting the Caledonian Horticultural Society was instituted. Dr Andrew Duncan took the chair, a Council was formed, Walter Nicol and Patrick Neill agreed to act as Joint Secretaries, and the Earl of Dalkeith was elected President. Neill was to serve the Society in the office of Secretary for the next 40 years. The Society's object was 'the encouragement and improvement of the best fruit, the most choice flowers and most useful culinary vegetables.' By 1824 it had received its first Royal Charter.

As early as I8I I the Council had appointed a committee 'to look out for a proper place for a Garden', but not until shortly after 
1820 did the Society come into possession of ten acres of ground known as Herd's Hill on the lands of Inverleith. For a time the Garden prospered, especially during the regime as Curator of James $\mathrm{McNab}$. In I836, when $\mathrm{McNab}$ was appointed to the Garden, it contained only three small hothouses, a vinery, a greenhouse and a stove. Twelve years later, when he left the employment of the Society, $\mathrm{McNab}$ had added a camellia house, two conservatories, a propagation house, a Winter Garden and an Exhibition Hall, and to some extent had voluntarily raised the necessary funds, by subscription, for their erection. In addition to the buildings there was a splendid collection of fruits, including oranges; a collection of camellias containing the finest and rarest kinds of the day; collections of azaleas, rhododendrons; plants from China, the Himalaya, Australia, South America-all assembled through James McNab's efforts.

The most remarkable of McNab's additions to the Society's Garden was the so-called Winter Garden, and by far the most important was to prove to be the Society's Exhibition Hall. The Winter Garden was a three-gabled structure occupying part of the site of the present Rock Garden in the Royal Botanic Garden. Designed by Drummond of Canonmills, it introduced, for the first time in Scotland, a fashionable promenade similar to the Jardin d'Hiver of the time in Paris. It was visited by a correspondent to the SCOTTISH AGRICULTURAL JOURNAL in I849, about the time $\mathrm{McNab}$ was transferring his loyalties to the Botanic Garden.

We visited this new temple of Flora last Saturday, and found portions of the intended quadrangle, $126 \mathrm{ft}$ long by $30 \mathrm{ft}$ broad, not only completed, but in a full blaze of internal beauty, from such an array of resplendent rhododendrons and chaste camellias, along with showy flowering shrubs and rare exotic plants, as we could not possibly have anticipated in the dead season. Mr McNab explained that, with a view to the opening of the promenade, this profusion of bloom had been brought on by forcing; and to this probably might be attributed the extraordinary purity of colour by which all the blossom was pervaded. But, indeed, although the supply of plants in blow at the Winter Garden must necessarily rob the other conservatories and hot-houses of their decorations, the plants were never before exhibited to the same advantage .... The intermediate spaces, which, in most conservatories, are given up to atmospheric vacuity, are, in the houses of the Experimental Garden, ingeniously hung with fine suspension plants, fed by a water glass and worsted syphon. One of these, a crimson camellia, of two-years' standing, is a thriving plant for such airy quarters. The coup d'oeil presented by the spacious front passage, along which the principal flowering specimens are arranged in a stand, beside the delicately attenuated 
pillars of fluted iron supporting the roof, forms a magnificent vista. $\mathrm{Mr} \mathrm{McNab}$ has exhibited immense tact in facing the structure to the north, by which means he not only calculates on preserving the plants longer in blow, but on affording a more uninterrupted light to the public arcade, here glazed over with panes of large size, without burning the plants with the glass (as now complained of so frequently in England), since the south and other parts of the structure, through which the sun's rays are to act, are glazed with small pieces. The contractor [Drummond] has great credit in his handiwork, as the building, frames, sashes, etc. are fitted up in a style of airy elegance impossible to be surpassed, and invested with all the means and appliances of modern invention, whether for heating or ventilation.

Though a great novelty at the time, and popular though it must have been with the Society's members, as well as on Saturdays with the general public, its life was to be limited. Ultimately it was to be pulled down and on its site a great rock garden was to be built. All that now remains is the foundation which periodically is uncovered when excavations in the present rock garden are in progress.

The Exhibition Hall (Plate via), on the other hand, was destined to be more permanent and certainly to serve a far more usefuleven scientific-purpose. In December I84I a proposition was submitted to the Society for erecting, by means of private voluntary subscriptions, a building suitable for the exhibition of plants, fruits, etc at the Society's competitions, for the reading of papers at the Society's meetings, as well as for many other purposes such as the exhibition of selected plants in flower from the hothouses in the Garden or from gardeners in the neighbourhood, as a museum for collections of named fruits and casts of fruit, as a botanical and horticultural library, and as a place of general resort for the Society's members. The proposition was favourably received, a committee was nominated to arrange all the details, and a printed statement was thereafter prepared and circulated to all members requesting subscriptions. By February 1842, having ascertained that the requisite funds would be forthcoming, the committee commissioned Mr David Cousin, the architect, to design the building which was completed early in $\mathbf{I} 843$.

The contract price, including the architect's fees, was $f^{6} 6804$ s. 9d. When once the hall was erected it was painted and certain additions made, all at a cost $\delta^{62}$ I7s. od. It was also estimated that a further $f$ ioo would be required for the furnishings. Thus the hall cost $£ 843$ Is. 9d. and by the time it was ready for occupation only $f^{612}$ I2s. od. had been subscribed. It fell to James $\mathrm{McNab}$ to make 
application to those members of the Society who had not as yet subscribed, for the remaining $£ 230$ 9s. 9d. The funds were forthcoming and the Exhibition Hall proved to be an invaluable asset to the Society's Garden until I864 when it was used as the Herbarium of the Royal Botanic Garden in which capacity it served botany in Scotland and throughout the world for the next one hundred years, until in fact a new Herbarium and Library was opened in 1964 .

Although $\mathrm{McNab}$ was succeeded as Curator of the Society's Garden by its Garden clerk, the young, energetic though modest, and scientific-minded William Wilson Evans, whose son was to become the most competent Scottish field naturalist of his day, and whose grandson William Edgar Evans was to hold an important post on the staff of the Royal Botanic Garden, the Society's Garden gradually was to meet with increasing financial difficulty which forbade further progress. On the other hand $\mathrm{McNab}$ 's appointment under Hutton Balfour in I849 was to usher in a thirty-year period of great progress at the Royal Botanic Garden.

Within a few weeks of McNab's appointment, Balfour began to campaign for extensive repairs to the glasshouses which were in exceedingly poor condition. He made strong representations to the Edinburgh MP, Sir William Gibson-Craig who was a Lord of the Treasury and was to prove himself a great benefactor to the City of Edinburgh. He was one of the chief originators of the scheme for the water supply of the City and a member of the Commission which was appointed in I847 to enquire into the whole subject of art in Scotland, as a result of which the National Gallery was built. Sir William, who had always taken a warm and deep interest in the welfare of the Garden, entered into Balfour's schemes and at once took steps to have the management of the Garden placed under the direction of Her Majesty's Commissioners of Woods and Forests. An immediate examination was made of the hothouses which were straightway put into an efficient state; they were repainted, after much of the rotten wood had been replaced, and a complete new system of hot water heating was introduced. Thus in 1849 the houses were in better shape than for many years.

Spurred on by his success, in the autumn of I 849 Balfour appealed to the Commissioners of Woods and Forests relative to the state of his classroom and the lack of accommodation for a museum. Success once again attended his endeavours; the matter was investigated and after various negotiations it was agreed that a new class- 
room should be built, at a cost of $\oint_{1}, 600$, and the existing one converted into a museum. At the same time arrangements were made for more ample accommodation for botanical research. In the provision of this new accommodation, Mr Matheson, the Clerk of Her Majesty's Public Works, closely collaborated with Balfour, as indeed did he on future occasions. Though work on the building of the new classroom-connected with the old one-only commenced on 4 th November 1850 it was ready for occupation by Balfour and his students on Ist May the following year.

Towards the end of June I85I the museum and the other rooms were finished and the whole was opened for public inspection. Balfour and $\mathrm{McNab}$ gave their own extensive private collections to form a nucleus for the museum and appealed to all interested parties for further contributions. Though these were slow to come the museum was opened to the public on Ist January I852 when upwards of 6,000 people crammed into the building to witness the result of the unremitting labours of the Professor and his Curator. According to the local press of the time visitors were gratified with most of what they saw. The building, however, received a little adverse criticism:

The cases in which the specimens are preserved seem to us to be much too heavy. They want a certain airyness and lightness which they ought to have had for such a purpose. In these days, when the Great Exhibition building ${ }^{\mathrm{I}}$ has given us a lesson on the cheapness of glass, we think larger panes and less wood work should have been employed, when the whole would not have appeared so heavy, and the specimens would have been better exhibited. The windows on the side of the building also are reflected on the glass of the cases, which often renders it impossible for the eye to penetrate into the interior. Had the hall been lighted from above, instead of from the sides, this defect would have been obviated, and much more room would also have been afforded for the numerous and still increasing objects of interest. Perhaps, when the Museum is more crowded, the authorities may yet be tempted to make this alteration, and then it will be considerably and profitably improved.

Too heavy though the cases may have been, they were to serve the museum well for the next hundred years and more and during much of that time in a less well-lit environment than that of $I 852 .{ }^{2}$

Having obtained his Museum of Economic Botany and new accommodation for teaching and research Balfour once again

\footnotetext{
'Joseph Paxton's great glass construction of $185 \mathrm{I}$, which covered more than 20 acres.

${ }^{2}$ See p.258-9.
} 
turned his attention to the glasshouses in the Garden-and especially to the Palm House. It was now twenty years old and so quick had been the growth of some of the palms that they had outgrown the House. Some such as Caryota urens and Metroxylon rumphii, the Wine and Sago Palms respectively of Malaya, periodically sent their leaves through the roof. A fine specimen of the former, over 4I ft high, had to be turned out of the House into the open ground where it was an object of great interest during the meeting of the British Association in August 1852, and astonished the famous Italian Professor of Botany, Parlatore, who, not knowing the history of its transplantation, took far too favourable an impression of the warmth of the Edinburgh climate. Of course the palm died during the cold weather two months later. Other palms in the House were greatly injured by overcrowding. These circumstances led Balfour to apply for an addition to the Palm House and, after a series of representations to the Commissioners of Woods and Forests, more particularly to Sir William Molesworth and Sir Benjamin Hall, aided by an excellent photograph (Plate vna) by Dr James Duncan showing some of the palms projecting their leaves for many feet through the roof of the old House, $\delta^{6} 6,000$ was voted by Parliament in 1855 for the purpose of a new Palm House (Plate virb).

The building was planned by the same Matheson who had been so helpful with the new classroom, and after some delay in regard to the letting of contracts, etc, work commenced in May 1856and the building was opened two years later. This is the house which still dominates the Royal Botanic Garden-situated to the west of the old Palm House with which it communicates. Throughout its construction Matheson, Balfour and $\mathrm{McNab}$ worked closely together. The House is substantially built of sandstone quarried at Bishopbriggs, near Glasgow, and the roof is formed of curvilinear iron rafters. $\mathrm{McNab}$ was the strong advocate for such solid masonry, claiming that it prevented rapid cooling and gave the shade important for the successful cultivation of many palms, especially those that are social in habit. McNab, a very successful cultivator of palms, claimed that too great sunlight was prejudicial; hence the western exposure of the front of the house. The sandy nature of the soil required that the foundations of the house be laid on two feet of concrete the laying of which proved difficult owing to vast quantities of water which poured in on all sides. On the concrete, six feet of underground mason-work was placed, and on this, 
solidly-built stone pillars $4 \mathrm{ft} 4$ ins in breadth, separated by arched windows $8 \mathrm{ft} 8$ ins wide and $22 \frac{1}{2} \mathrm{ft}$ high, were erected. This was the base for the great iron and glass roof.

The building has the form of a parallelogram, being from north to south roo $\mathrm{ft}$ over the foundation and about $90 \mathrm{ft}$ within the walls, $57 \mathrm{ft}$ from east to west, and $70 \mathrm{ft} 6$ ins high. The sides form an arcade $35 \mathrm{ft}$ high with the outside face relieved by pilasters and entablature of the Tuscan order-the arches being filled in with glazed cast-iron frames. The roof, of cast-iron rafters and glazed sashes, forms a two-staged dome, each stage about $\mathrm{I} 7 \frac{1}{2} \mathrm{ft}$ highthe lower one rising from the top of the sides to half-way up the roof, where a base is formed for the upper one. Galleries are provided at the base of each of the domes for convenience of access in case of repairs. Inside there is a series of fourteen light cast-iron pillars placed at a distance of $\mathrm{I} 2 \mathrm{ft}$ from the sides, forming a rest for the top of the lower dome and for the base of the upper one.

$\mathrm{McNab}$ made a great study of the heating of the house. He visited all the leading gardens in Britain to examine heating systems as a result of which he evolved the flued saddle-boiler which was manufactured by Schott's Iron Company of Leith Walk. Four such boilers were used in the hot water heating of the house and they were connected with I, 3 I 6 feet of 5 -inch bore cast-iron pipes. Two of the boilers were connected with pipes which passed round the whole house, one set of pipes going to the right and the other to the left. The pipes of the other two boilers passed in the first instance to the centre of the building and then returned by the outsideeach set of pipes thus passing round half the building. In this way was the heat increased or decreased as required.

Such was, and is, the building which cost $f^{6,500 \text {, which was }}$ opened on Ist April 1858 and to which the palms were transferred from the old Palm House by McNab by 3 oth April-a very great feat of planting when it is realised that the greater part of the palms had to be retubbed and that some of the specimens, notably Livistona chinense and Sabal umbraculifera, with the earth at the roots, weighed from seven to eight tons. These two palms for the last eighteen years had been grown in large square boxes without bottoms, each $4 \mathrm{ft} 6$ ins in diameter and $4 \mathrm{ft} 3$ ins deep. The Livistona had a stem $6 \mathrm{ft}$ in circumference at the base and $42 \mathrm{ft}$ high, whilst the Sabal stem was $5 \mathrm{ft} 6$ ins at the base and $28 \mathrm{ft}$ across the globular-shaped top which consisted of great heavy leaves. This latter plant had been removed from the stove in the old 


\section{PLATE VII}

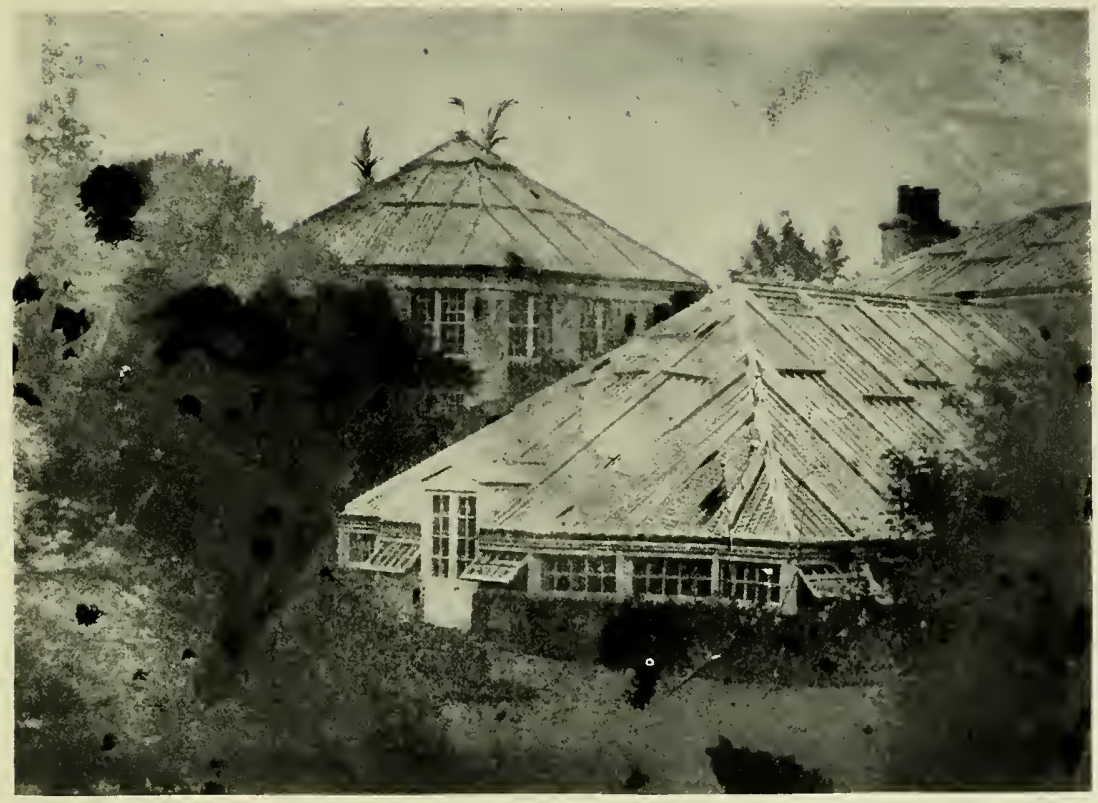

(a) The state in 1854 of the Palm House opened in 1834

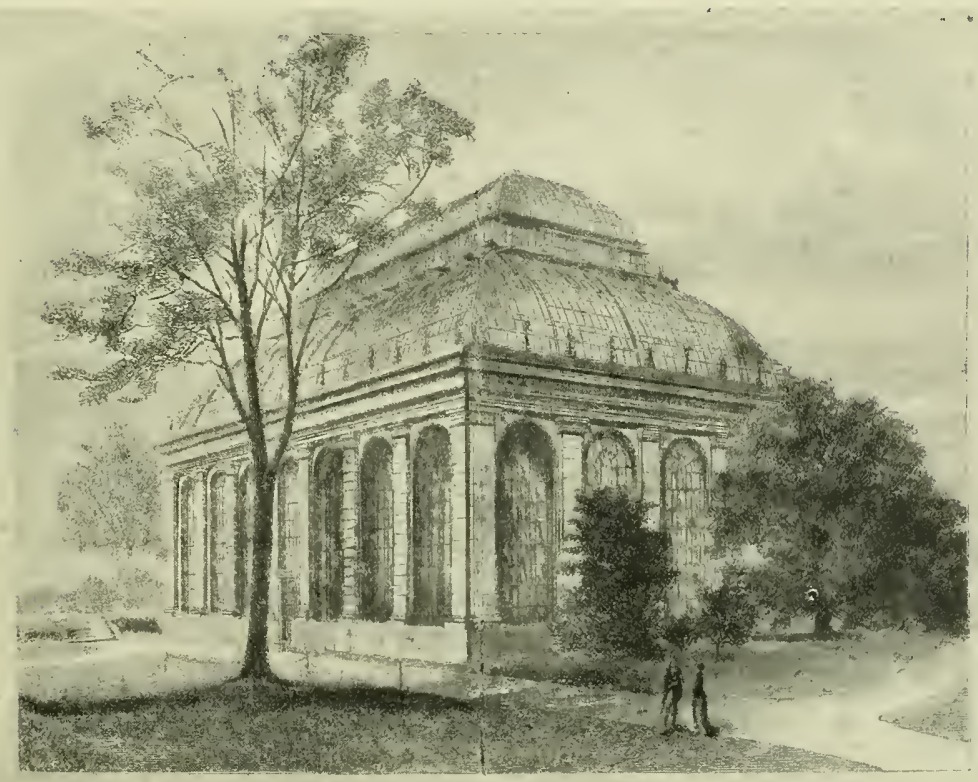

(b) The Palm House opened in I 858 
Botanic Garden at Leith Walk in 1822 and at Inverleith, for thirteen years, had been maintained in a lean-to house; as this house was only I $8 \mathrm{ft}$ high at the back and $7 \mathrm{ft}$ at the front, Sabal had been greatly hampered for accommodation and in 1834 had been moved to the new Palm House. Its present transference then, into the latest house, was its third move in thirty-four years. The retubbing of these great plants (some of the tubs were over $22 \mathrm{ft}$ in circumference) and their journey from one house to the other was not lacking in adventure, and $\mathrm{McNab}$ recorded one exciting episode ${ }^{I}$ attending the perilous task of cutting off the top of Caryota urens before it could be removed from the high lantern part of the roof of the old house. William Bell, one of the journeymen gardeners, volunteered for the task and accomplished it with safety; the glass was broken from the outside and the top removed with a saw. $\mathrm{McNab}$ recorded his experience with the retubbing of palms on several occasions, but notably in the scotrisH GARDENER for 1856 .

For a time $\mathrm{McNab}$ had to employ canvas shades to prevent excessive glare from the sun from reaching the plants--because the light iron sash bars cast little or no shade. Thus, when Balfour was given $f, \mathrm{I}, 000$ for reroofing the old palm house, $\mathrm{McNab}$ at first inclined to the view that the new roof should be of wood and glass because the small panes and the thicker wooden bars would cast more shade than larger panes and iron sashes. Even so, in 1859 it was resolved that a new iron roof should be constructed and this was completed in I860. In this way was the height of the old palm house increased to $50 \mathrm{ft}$. Whilst this work was in progress a temporary partition of old window glass was erected to separate the two houses so that one might contain palms and trees of hot climates and the other arborescent plants from warm temperate regions.

The great new house, still the highest of its kind in Britain, was acclaimed by both press and public alike-though not all in the quaint terms of the FALKIRK HERALD of Igth August I858:

They [the palms] seem thoroughly at home however, in their new place, and, lofty although the house be, if they proceed at their present rate of growth, few years will have elapsed before they be demanding more head room. The tropical aspect of this house is heightened by the fact that the man in attendance upon the visitors is a bone fide African. The presence of

ITRANS. BOT. SOC. EDINB., VI (I857), p.5-6. 
such a man gives a consistency to the scene; and, besides, it is found that a native of the sunny climes, where the palm trees grow, is better able to stand the high temperature of such a house than one of our pale-faced race.

Botanical instruction to hundreds of students, for whom he specially wrote text-books, management of the Botanic Garden, championing the cause of Edinburgh societies, especially the Royal Society and the Botanical Society, as well as the Royal Caledonian Horticultural Society, all combined to make Balfour an overworked man, and in 1854 he was given an assistant-John Sadler who was born at Gibbleston in Fife in 1837. Sadler (Plate vib) received his early education at the parish school of Dunbarnie and at Perth Academy before assisting his father who was gardener at Moncrieffe House to Sir Thomas Moncrieffe. At the age of I7 he came to Edinburgh to join the staff of the Royal Botanic Garden, was employed first partly in the propagating department and partly in the Herbarium in connection with Balfour's botany classes, and was fortunate enough to attend some of the University classes. His interest in plants quickly brought him to the attention of the Professor who appointed him his assistant, a post he occupied and the duties of which he faithfully discharged for close on a quarter of a century. An inveterate rambler over the countryside in his study of British plants, he was to gain a great knowledge of the Scottish flora-especially of the flora of Perthshire-on which he was to lecture regularly to the Botanical Society of which he was appointed Assistant Secretary in 1858 , a post he filled until 1879 when he was rewarded with a handsome testimonial of approval. At the same time, through his intimate connection with the teaching of botany in the University, he developed into an excellent all round botanist, in 1869 receiving from the Royal Caledonian Horticultural Society, of which he had for long been a Councillor, the Neill Prize for his eminence as a Scottish botanist. When, in I867, the teaching of botany was introduced in the Royal High School, Sadler was appointed lecturer; and here he lectured until I879.

The problem of the overcrowding of the palms had been solved -at least temporarily. Balfour and $\mathrm{McNab}$ now had to turn their attention to the plants out of doors, especially to the congestion of the trees and shrubs which were crowded together in miscellaneous groups wherever space could be found for them with no semblance of any scientific arrangement. Clearly the area of the outdoor garden had to be greatly extended beyond its present fourteen acres. 
And in two stages the acreage was almost doubled by I864. The acquisition of $2 \frac{1}{2}$ acres of land to the west of the new Palm. House, soon after the opening of the House, was a great help. But it was the acquisition of the Garden of the Royal Caledonian Horticultural Society in I864 which really solved McNab's planting problemsand gave free scope for the use of his tree transplanting machine.

In 1856 the Royal Caledonian Horticultural Society was in financial difficulty, owing to loss of membership, non-payment of subscriptions, and a general lack of interest in the Shows. The Council had endeavoured to reduce expenditure by avoiding all unnecessary outlay and at the same time to increase income by the cultivation and sale of plants. But this had not been effective and in 1857 , realising that it was not possible to administer the Garden efficiently without accumulating debt, the Council memorialised Government to take the lease into its own hands and administer the Garden in conjunction with the Botanic Garden. Conferences were held with Lord Panmure, Sir Benjamin Hall and the Secretary of the Treasury-but without positive result.

In 1858 the Council learned that Government had withdrawn its annual grant of $f_{200}$ which the Society had received since I853and thus the Society was left without the means of paying the annual rent of EI40 5s. od. to the Office of Works. Under these circumstances the Council found it necessary either to arrange with nurserymen to take over the Garden or to hand it over to the Government in the hope that it would be amalgamated with the Botanic Garden. The second alternative was proposed to the members and shareholders-and was accepted and confirmed in December 1859 .

Then for the next few years negotiations were carried on with the Government, partly by memorials and partly by personal interviews with the Commissioners of Woods and Forests, the Secretary of the Treasury, the Chancellor of the Exchequer, Lord Palmerston, the Duke of Argyll, and others. In all these negotiations Sir William Gibson-Craig played a prominent role. In the meantime, though the Garden was maintained with the lowest possible expense, the debt to the Office of Works gradually accumulated to the extent that, in I864, it amounted to nearly 6850 . There was also a further debt of $£ 300$ to the Royal Bank of Scotland. In the end, in I864 the Government proposed to give $f, \mathrm{I}, 000$ for the surrender of the lease, including the Exhibition Hall, the Winter Garden, the Gardener's House, on the condition that out of this 
sum the debt due to the Office of Works should be paid in the first instance. Government further proposed to give the Garden, in whole or in part, to the Botanic Garden. To all this the Society naturally agreed, and in this fashion was a further Io acres added to the area of the Botanic Garden.

This was not to be the end of the Garden's expansion under Balfour's regime for shortly before he retired in 1879 the grounds of Inverleith House were taken over as an Arboretum for students in forestry. 


\section{CHAPTER THIRTEEN}

\section{The Garden in 1870}

BY I 870 HUTTON BALFOUR HAD BEEN REGIUS KEEPER ÓF THE Garden and Professor of Botany for 25 years, James McNab had been Curator for just over 20 years, and John Sadler, Balfour's assistant, for just over I5 years. The Garden was 200 years old and, due to the combined and sustained efforts of this triumvirate, for its size, was the equal, in scientific importance, of any Garden in Europe. Its general layout, at this time, is illustrated on Plan I.

On entering the Garden, immediately beside No. 20 Inverleith Row, there was a walk leading past the Curator's House and to the entrance to the classroom. The walk was planted with such conifers as the yew, the Deodar-cedar, the Big Tree Sequoiadendron giganteum, as well as several specimens of hawthorn, including that known as Weeping Queen Mary Thorn. The Big Tree had been planted in 1861 by Sir Robert Christison, the eminent toxicologist, who was a staunch supporter of the Garden where he periodically measured the rate of growth of the trees; on planting, the Sequoiadendron was a little over $6 \mathrm{ft} \mathrm{high,} \mathrm{and} \mathrm{in} 1870$ close on $20 \mathrm{ft}$.

Beyond the Curator's House ${ }^{(I)} \dagger$ was the Botanical Museum(2), open to the public and formed from the old classroom and filled with specimens contributed mostly by Balfour and his former pupils, and by McNab. They were intended for the teaching of botany, for instruction in form and structure and in economic and medicinal products and uses. There were several glass-covered tables, three of which were occupied by collections of conesAraucaria, Pinus, Larix, Abies, Picea, Sequoia, Cryptomeria, Thuja, Cupressus, Juniperus, Taxus, Torreya, and others, as well as cones of cycads such as Stangeria, Cycas and Encephalartos. Two of the

t The numbers in brackets are the reference numbers on Plan I facing p.I6o. 
tables contained fossil plants, especially those from the Carboniferous period, as well as specimens of coal; one of the most noteworthy of the fossils was that named Pothocites grantonii which Dr Robert Paterson had discovered in the exposed coal strata along the coast at Granton, Edinburgh, and which he had described in the first volume of the TRANSACTIONS OF THE BOTANICAL SOCIETY OF EDINBURGH.

Another table was devoted to dried specimens and drawings illustrating some of the plants of the Bible, a subject dear to Balfour's heart.

Between the windows on the north and south sides were six glass cases, those to the south containing a series of models illustrating the parts of the plant, especially the flowers and fruits, as well as the structure of ferns, mosses and fungi; the cases on the north side contained specimens of articles manufactured from grasses, from various vegetable fibres, as well as sections of tree ferns. At the east end stems, flowers, fruits and the products of palms were displayed, whilst collections of exotic woods occupied the west end. In front of the windows were tables containing special specimens of woods, fruits and fossils. Such was the ground floor.

The wall cases of the gallery on the east and west sides were filled with glass jars containing medicinal and economic products, and fruits; specimens of tea, coffee, chocolate, sugar, etc, all arranged in their appropriate plant families. On the north and south sides were ten large upright cases containing vegetable dyes, barks, fibres and fruits, whilst around the gallery was hung a collection of framed dissections of flowers, including those of grasses and sedges, of lichens and other non-flowering plants, all executed by former pupils of the Botany Class, including the eminent physician and amateur geologist Dr Charles Murchison; another physician and authority on sedges, Dr (later Sir) W. O. Priestley; Dr William Lauder Lindsay the lichenologist, and Mr John Maclaren who was to establish the famous Golden Gate Park in San Francisco on a great moving sand dune.

Beside the Museum were the classrooms ${ }^{(3)}$. The large room seated about 300 students and was so constructed that the Professor and his assistant could exhibit living specimens of plants in pots, dried specimens from the Herbarium, large drawings, and minute structures under microscopes. A class herbarium, illustrating genera and species arranged in families, was maintained in this main room. Behind the classroom was the Professor's retiring room, with cases 
for specimens, drawings, and books used for class purposes. Above the retiring room was a room devoted to 'microscopical research' in which 50 students with tables, microscopes and dissecting apparatus could be accommodated.

Proceeding north ${ }^{(4)}$ there was a collection of ferns and those allies of the lilies with stiff long narrow leaves and heads of whitish flowers, the yuccas, whilst in the far north-east corner an old willow had been given special protection close to the tablet to John Williamson which had been erected by John Hope in the Leith Walk Garden in I78I. Along the north wall(5) were many interesting plants, some of which were given the protection of matting during the winter; there were camellias, Wisteria sinensis, the Judas Tree Cercis siliquastrum, the Maidenhair Tree Ginkgo biloba (at that time known as Salisburia adiantifolia), the black and white mulberries Morus nigra and $M$. alba respectively, the Mandrake Mandragora officinarum, species of Acacia and Eucalyptus from Australia, Clematis, Bignonia, the Chinese jasmine Jasminumn nudiflorum-one of the hardiest and finest of winter-flowering shrubsthe Pomegranate Punica granatum and the common fig Ficus carica. The border at the base of the wall was reserved mainly for bulbous plants, whilst an area in the north-west corner of the Garden ${ }^{(6)}$ was given over to duplicate herbaceous plants which were used for class demonstration.

The Palm Houses (7), the pride of $\mathrm{McNab}$ and a source of great interest to Balfour's students, were very popular with the general public. The old house now contained many half-hardy palms and tree ferns, as well as other trees, which required protection from frost but not a very high temperature. Among the palms, the European Chamaerops humilis and its tall variety arborescens, the Fanleaved Palm of North China Trachycarpus fortunei, T. martianus from the Himalaya, the Wax Palm of the Andes of Colombia Ceroxylon andicola, Jubaea spectabilis of Chile, Phoenix humilis of India and China, and the Australian Livistona australis, named after Murray of Livingston from whose garden came many of the plants for the Physic Garden in 1670-all were outstanding. Likewise were the tree ferns-Dicksonia antarctica from Australia and D. squarrosa and Cyathea dealbata both of New Zealand, as well as the conifers Dacrydium and Agathis and many other southern hemisphere plants.

At this time the most spectacular plant in the large Palm House was Arenga pinnata (then known as A. saccharifera), the Sugar Palm 
of the Indian Archipelago, from which sugar is procured from the juice of the large sheaths which enclose the flowers. It was almost touching the roof and a few years later had to be cut down. But there were many other splendid palm specimens. There was the West Indian Fan Palm Sabal umbraculifera which had been brought from the Leith Walk Garden in r822; a species of Cabbage Palm Prestoea montana from Venezuela, the young shoots of which are used like cabbage; the Prickly Pole Acrocomia sclerocarpa of Brazil; the Date Palm and the Palm of the Bible Phoenix dactylifera, as well as the Wild Date of India P. sylvestris; the Talipot Palm of S. India and Ceylon Corypha umbraculifera whose great fan-shaped leaves are used for fans, umbrellas, thatching, etc; the Oil Palm of Guinea Elaeis guineensis yielding the noted palm oil; the Wine Palm of India Caryota urens which yields palm wine and a kind of sago; the West Indian Cabbage Palm Roystonia oleracea; the pan-tropical Coco-nut Palm Cocos nucifera; and Plectocomia elongata of Java and Sumatra, a weak-stemmed palm having large claw-like spines on the lower part of the mid-rib of the leaf and on the leaf-stalk for the purpose of climbing; these and many more.

Palms apart, there was the beautiful tree fern from Queensland and Norfolk Island Alsophila excelsa; the Anchovy Pear Grias cauliflora from the West Indies; bananas and bamboos; the sugar cane of commerce Saccharum officinarum, cultivated from time immemorial; the Longyen fruit of India, allied to the Litchi, Euphoria longana; the Allspice, Pimento or Jamaica Pepper Pimenta officinalis; the Screw Pine Pandanus with numerous stem-like roots and large bunches of fruit; the Banyan Tree Ficus benghalensis also with remarkable stem-like roots; the Caoutchoue plant of India Ficus elastica, and F. religiosa the Pepul Tree of the Hindus; Swietenia mahagoni the Mahogany of Central America and the West Indies; the Travellers' Tree of Madagascar Ravenala madagascarensis, yielding water fluid from the basal sheathing part of the leaf stalk; and the Mexican Monstera deliciosa with edible fruits and the leaves perforated by large holes.

To the east of the Palm Houses was a range of low-roofed houses and propagating pits ${ }^{(8)}$ wherein could be found many economic and medicinal plants. There was the Mango tree Mangifera indica which yields a well-known, somewhat kidney-shaped tropical fruit; the Mangrove tree Rhizophora mangle, remarkable for its adventitious stem roots which grow into the mud at the mouths of tropical rivers and serve to prop up the parent tree; several 
species of the Peruvian Bark tree, including the Red Bark Cinchona succirubra, the Yellow Bark C. calisaya, and the Brown Bark C. officinalis, all yielding quinine; the native of Brazil, the Ipecacuana plant Cephaelis ipecacuanha, which, like the cinchonas, has been introduced into India; several species of Smilax the Sarsaparilla, the roots of which are used as an aromatic stimulant; the medicinal Squill Urginea maritima, from the large bulbs of which is expressed the substance used for coughs; the Dumb Cane or Dumb Plant Dieffenbachia sequina, of which any part of the plant, on chewing, causes a swelling of the tongue and dumbness for several days; the Taro Colocasia antiquorum, cultivated in the tropics for the edible corms; the family Araceae, to which Colocasia belongs, are generally acrid, yield starch, while the leaves of some of them distil a watery fluid. There were species of the Carrion Flower of Tropical and South Africa Stapelia, the flowers of many of which give off a foetid odour, much like putrid carrion, and thereby attract insects which are useful for fertilisation; specimens of Streptocarpus rexii from the Cape, one of the seed leaves or cotyledons of which remains as a permanent leaf and constitutes the only leaf of the plant; Bryophyllum pinnatum, widely distributed in the tropics of the Old and New Worlds, the leaves readily producing buds; many species of cactus-Cereus, Echinocactus, Mammillaria and others, including of course the well-known night flowering Selenicereus grandiflorus which opens its flowers late in the evening and closes them by morning never to open them again. There was the Croton-oil plant Croton tiglium of India, the seeds of which, by expression, yield an acrid oil; the Indian Nux-vomica plant Stryclinos nux-vomica, yielding the very poisonous alkaloid strychnine; the Nutmeg Tree of the East Indies Myristica fragrans, the seeds of which supply the spice called nutmeg, and the scarlet covering of the seeds the mace of commerce; the Pepper plant Piper nigrum, a climbing East Indian species, the dried unripe fruits of which constitute black pepper, or, if the dark outer fleshy covering is washed off, white pepper. And there was the Rice plant Oryza sativa, the fruit of which provides food for vast numbers of people in East and South-east Asia.

Many alpine plants were accommodated in cool frames in this part of the Garden.

Beyond the compost heaps ${ }^{(9)}$ was the range of hothouses(10) mostly built by Professor Graham and renovated by Balfour and $\mathrm{McNab}$. Each house contained a diversity of plants, many of them 
of economic importance, growing in the environment $\mathrm{McNab}$ believed to be most appropriate. No one house was devoted to one group of plants-orchids, or ferns, or cacti, for example, as was to be the rule in later years. For instance the contents of the house at the east end of the range( ${ }^{(\text {Ioa })}$ were plants requiring stove conditions and, although there were many orchids of warm climates, with pseudo-bulbs and aerial roots, some of them attached to blocks of wood, the majority of the plants were grown for their economic interest. The only orchid of any economic value was there, the Vanilla Orchid Vanilla fragrans of the West Indies; the dried fruits yielded the vanilla of commerce which is now produced synthetically. Two species of Cinnamomum were there: C. zeylanicum of India and Malaya, the bark of the young twigs producing cinnamon, and C. cassia, the Cassia-bark sometimes used as an adulterant of cinnamon. There was the Arabian coffee Coffea arabica whose seeds form the coffee 'beans' of commerce; the cocoa of Central America and Trinidad, Theobroma, with fruits 8 inches long containing up to Ioo bean-like seeds; the Bitter Quassia Quassia amara whose scentless wood is extremely bitter and has been used as a tonic; the West Indian arrowroot Maranta arundinacea; the ginger of the East Indies Zingiber officinale; the Litchi fruit tree Litchi chinensis of S. China, widely grown in the tropics and eaten both fresh and dried, as well as preserved in syrup; Tamarindus indica of Tropical Africa and the West Indies, the tamarind of commerce which is used medicinally in both European and native medicines-the bark, wood, leaves, flowers and seeds all being economically useful; the clove of the Moluccas Eugenia aromatica, the dry unexpanded flower buds being the cloves of commerce; Artocarpus incisa the Bread Fruit of Malaya and the Pacific Islands; Lagetta lintearia of the West Indies, the Lace Bark of commerce derived from the many layers of the inner bark; the aquatic Lace Leaf or Lattice Leaf of Madagascar Aponogeton fenestralis (for long known as Ouvirandra), with its leaves full of holes and its roots being used like yams; Palaquium gutta the Gutta-percha Tree of Malaya; Garcinia xanthochymus the False Gamboge of India, yielding large quantities of indifferent gamboge and not to be confused with the true Gamboge, Garcinia cambogia of the East Indies, whose stem, on notching, yields the gamboge of commerce; Haematoxylon campechianum, the Campeachy Wood of Central America and the West Indies and the source of the dye haematoxylin which is made from the dried brownish-red heartwood broken into chips before 
use; the Sand-box Tree of Tropical America Hura crepitans, whose capsular fruits burst with great force and noise; species of cotton, Gossypium, the hairs covering the seeds being the cotton of commerce; the Double Coconut, or Coco de Mer, Lodoicea maldavica of the Seychelles, noted for the immense size of the seed of which the usually lobed fruit, which may weigh as much as $40 \mathrm{lbs}$, usually contains but one; and two plants which had been much used by Professor John Hope in his demonstrations to his students-the Sensitive Plant of Tropical America, Mimosa pudica, whose leaves exhibit movement at the slightest touch, and Desmodium gyrans, the Telegraph Plant of India, which, at temperatures above $72^{\circ} \mathrm{F}$ during the day moves its lateral leaflets steadily round in an elliptical orbit, and at night droops them downwards.

More economic plants, more palms, more tree ferns, and a collection of bananas were displayed in Iob, whilst Ioc again contained a mixed collection of stove plants together with several cycads-some of the most primitive of seed-bearing plants allied to the conifers-and a series of tropical ferns which were exhibited on the stone platform in front of the house-species of Aneimia, Platycerium, Adiantum, Gymnogramma, etc. The next house (rod) was to some extent used as a growing house and housed young plants which later would find a place in the other houses. Even so one outstanding plant was permanently accommodated here, Cyperus papyrus the Papyrus or Egyptian Paper Reed, so called because the ancient Egypians used the cellular inner part of the stem for making paper.

Half-hardy plants demanding cooler conditions were housed in Ioe. Here were camellias; tree ferns; several species of Passiflora the passion-flower, and several hedychiums of the ginger family; the Cashew plant, Anacardium occidentale of the West Indies, the kernel of the nut yielding an oil, and the wood a gum used in varnishmaking; Sapium sebiferum the Tallow Tree or Vegetable Tallow of China, grown for the wax which covers the seed and which is used for candles and soap making. The centre house (rof) was again for half-hardy plants of an arborescent nature, chiefly those from the southern hemisphere, whilst Iog was a cool house devoted to camellias and other plants of mild temperate climates, some palms, some tree ferns and several insectivorous plants such as several species of Sarracenia of North America, Darlingtonia californica of the mountains of central California to southern Oregon, 
the Venus Fly-trap Dionaea muscipula of Carolina, and, most remarkable of all, the Australian pitcher plant Cephalotus follicularis, which even today is a rare plant in cultivation.

More tall temperate plants, chiefly from New Zealand and Australia, were in Ioh. But the most remarkable plant in this house was a large Camphor Tree from Japan, Cinnamonum camphora, whose wood, heated with water, is the source of camphor; this particular plant was $30 \mathrm{ft}$ high with a stem nearly $3 \mathrm{ft}$ in circumference. A mixed collection of plants which were frequently changed during the course of the season occupied roi, whilst rok was devoted to more southern hemisphere plants such as species of Epacris, Banksia and Acacia, as well as proteas from the Cape. Heaths from the Cape had always been well cultivated in the Royal Botanic Garden, especially by William McNab, and many of the plants which he had grown were still thriving in the house at the west end of the range, Iol.

The lawn to the south of the houses(II) was given over to conifers-deodars, pines and spruces, several species of Yucca, and two palms-the European Chamaerops humilis which was close on 50 years old, and Trachycarpus fortunei which had been introduced from China in $\mathrm{I} 844$ by Robert Fortune who in 1840 had been employed under William McNab before joining the staff of the Royal Horticultural Society. Plants for class demonstration occupied I2, and hardy heaths (which were one of James McNab's specialities) and azaleas I3. To the west of this latter area was the old yew which had grown originally in the old Physic Garden and which had been thence transported to Leith Walk-and finally to its present site. And here it prospered until January 1968 when it was destroyed by the hurricane which hit the city in the early morning of the Isth. In front of the yew was the monument to Linnaeus which had been erected by Professor Hope in 1779, and which today stands to the north of the New Exhibition Planthouses.

Hardy herbaceous plants were displayed in area I4, and medicinal and poisonous plants in 15 -and some of these latter had to be protected in the winter. Roses and Ghent azaleas occupied I6 and a collection of British plants, arranged in their families and mostly gathered by Balfour and his students on their excursions, area 17 . Near to this last area was a triangular group of conifers, all in excellent health. Pseudotsuga menziesii the Douglas Fir was the best specimen; it was $52 \mathrm{ft} \mathrm{high,} \mathrm{had} \mathrm{a} \mathrm{branch} \mathrm{spread} \mathrm{of} 28 \mathrm{ft}$ and the stem nearly $7 \mathrm{ft}$ in circumference. The Deodar Cedrus deodara 
was $38 \mathrm{ft}$ high, Abies procera the Noble Fir $50 \mathrm{ft}$ high, Pinus lambertiana the Sugar Pine $32 \mathrm{ft}$ high, and P. wallichiana the Bhutan Pine $35 \mathrm{ft}$ high.

From I8, excellent views of Edinburgh were to be obtained, and, because the Queen and the Prince Consort had visited the Garden in October I86I, the views from I8 were known as 'The Queen's Views'. In this area trees had been planted by HRH The Prince of Wales, HRH The Duke of Edinburgh, the Prince of Hesse, and Lord Palmerston.

Area I9 was a cheerful sight in the spring, for here was a collection of bulbous plants-snowdrops (Galanthus), Crocus, Scilla, snowflakes (Leucojum), Erythronium, Sisyrinchium, Puschkinia, Fritillaria, Narcissus. As was appropriate for a Botanic Garden in those days, the plant families occupied rather a large area(20). The families were planted in beds, the beds were labelled and arranged in three groups. The first was devoted to the Dicotyledons-the embryo of the seed having two seed-leaves or cotyledons; the second to the Monocotyledons-the embryo having one cotyledon; and thirdly the Acotyledons-the embryo having no cotyledons; this last group was illustrated by ferns and horse-tails.

Aquatic plants, including water lilies, were grown in the Pond(2I) and more plants for class demonstration in area 22.

The rest of the Garden (23-4I) was formerly the Garden of the Royal Caledonian Horticultural Society and was almost entirely the creation of James McNab. It was he who had planted the Pinetum with some semblance of grouping as is shown on the plan 23-32. It was he who had planted the variegated trees ${ }^{(35)}$, including oaks, elms, maples, poplars, etc; the weeping trees(36) birch, elm, ash, oak; the fastigiate trees(37) _oaks, lombardy poplars, etc, and the general collection of trees and shrubs ${ }^{(4 I)}$. Unfortunately these trees, though many of them were young, were badly overcrowded and both $\mathrm{McNab}$ and Balfour were deeply conscious of the fact that, if an Arboretum of any pretensions was to be formed, much more land would have to be provided.

Many of the trees had been transplanted from other parts of the Garden when they were of considerable size and the operation had been performed by the Garden's famous transplanting machine (Plate vIc). This machine originally had been invented by William $\mathrm{McNab}$ and had been in active operation in the Garden for thirtyfive years. However the transplanting in the Garden's new extension 
caused the working parts of the machine to be considerably altered and greatly strengthened, thus facilitating the raising of a much greater amount of soil with the plant, and with fewer men assisting, than it could formerly accomplish. The merit of James McNab's machine was that a shrub or tree weighing from $18-30 \mathrm{cwts}$, after being prepared, could be raised, conveyed, and planted without being subjected to any undue stress or even the possibility of injury. $\mathrm{McNab}$ discovered that, if water was copiously used, trees and shrubs could be moved safely during any of the spring, summer or autumn months-and in fact much of the transplanting in the Pinetum was done during May, June and July. As several visitors to the Garden, after seeing the machine in operation, had expressed a desire to possess one, $\mathrm{McNab}$ arranged for his model to be commercially produced. As a result two types were built by Alexander Hislop, Agricultural and Horticultural Implement Works, Canonmills, Edinburgh. The first type, which lifted a root ball of 48 inches by 40 inches, complete with all its gearings sold for f22 Ios. od., whilst the other, to lift a ball 42 inches by 38 inches, cost frg rss. od. The machine in the illustration weighed about $8 \frac{1}{2} \mathrm{cwts}$, and was constructed of a strong frame of wood and iron, supported on wheels, with two windlass rollers in front, and two at the back, the back rollers being so arranged that they could be removed to enable the machine completely to enclose the plant being moved.

$\mathrm{McNab}$ in some measure had also been responsible for the Conservatory or so-called Winter Garden ${ }^{\left({ }^{3}\right)}$ and the Herbarium ${ }^{(38)}$, in that, as Curator of the Garden of the Caledonian Horticultural Society, it had largely fallen to him to solicit subscriptions, from members, for their erection. The Herbarium, formerly the meeting room of the Society's members, was now serving a splendid scientific function containing as it did a large collection of dried specimens of plants arranged in cases, in plant families, according to a geographical system-collections of the plants of Britain, Europe, Asia Minor, Palestine and Syria, East Indies, China and Japan, North America, South America, Australia, New Zealand, Africa-especially the Cape of Good Hope-Western Africa, Abyssinia, and Algeria, as well as those from the Arctic. There was also a special collection of medicinal and economic plants. The cryptogamic plants formed another special collection, including ferns, mosses, lichens, fungi and algae, from all parts of the world. The Herbarium embraced all the collections made by Dr Robert 
Kaye Greville, author of the FLORA EDINENSIS of I824 and the SCOTTISH CRYPTOGAMIC FLORA of I823-28, as well as those accumulated by Professor Balfour. Here was also housed, for the first time adequately, the herbarium of the Botanical Society containing plants collected by such well-known botanists as Wallich, Roxburgh, Wight, Hooker, Harvey, Gillies, Tweedie, Thomson, Munro, Jameson, Gardner, Spruce, Drummond, Douglas, Jeffrey, Anderson, Mossman, Stewart, Cleghorn, Campbell, Lauder Lindsay, Wilson, Lange, Ritchie, Captain Burton, Captain Parry, Jardin, and others. A separate case contained the Indian collections of Francis Buchanan (afterwards Hamilton), and a special set of cases, presented by the late Archibald Menzies, contained plants collected by him during the voyage of VANCOUVER of I790-95.

Lying in front of the Herbarium was the trunk of a large fossil tree - Araucarioxylon-which had been found in Craigleith Quarry.

Most visitors to the Garden in I 870 seem to have found one of the most recent additions of very great interest-the Rock Garden(34), which was still in the process of construction, at this date being $\mathrm{I} 90 \mathrm{ft}$ long and $85 \mathrm{ft}$ wide, and which was situated to the south of the Winter Garden. It was built with a northern aspect and had a uniform terraced slope of I $2 \mathrm{ft}$. Ultimately it was planned to have the width $\mathrm{I} 20 \mathrm{ft}$ and the height $\mathrm{I} 8 \mathrm{ft}$. To modern eyes, this construction of $\mathrm{McNab}$ 's presents a remarkable appearance (Plate var) and one wonders how it could possibly have been conceived. It was nevertheless to become one of the Botanic Garden's greatest assets. It is revealing to allow $\mathrm{McNab}$ to speak for himself, for he stated his ideas and intentions in an article in THE GARDEN of I6th December I87I:

Rock Gardens may be looked upon as comparatively modern institutions, while rockeries are of ancient date. The latter are excellent in their way, but depend much on the nature of the material at the command of the operator, and on being constructed in such a manner as to produce a landscape effect. In rockeries the suitable and geological arrangement of the material is generally aimed at, more than a scientific or artistic distribution of the plants intended to be grown. But with rock gardens, on the other hand, the arrangement and formal distribution of the plants are specially to be considered. It is, however, not necessary that artistic effect should be laid altogether aside, for it is quite possible to have a graceful arrangement without sacrificing the individual health and habit of the plants. For a long series of years I have been enamoured by the diversified forms and extreme beauty of alpine plants, having always had under my charge a large number of these deserving favourites. Their cultivation, however, had always been 
in pots, plunged in ashes in raised pits, covering with glass during the winter months when necessary.

Some years ago the removal of a high wall which separated the botanical from the old experimental garden here became necessary, to throw the two establishments into one. To utilize this large portion of old building material I commenced what I call a rock garden, in contradistinction to the rockeries which I had previously seen in many places throughout the country, where alpine and herbaceous plants, shrubs, both evergreen and deciduous, and often trees, were indiscriminately growing together, the stronger and widerspreading plants often smothering the weaker. The general effect of such rockeries when judiciously constructed was good, particularly in the eyes of people not having a botanical taste. In the construction of the rock garden here, I got the stones of the old wall just alluded to split up longitudinally, and arranged in a piece of sloping ground facing the north, which I had previously laid out in an undulating and somewhat geometrical form, and which I had divided into uniform sections, separated by stone paths and steps. These sections were then divided into angular compartments of various sizes, and each filled with soils suited for the various plants to be put into them. The compartments of the various sections were afterwards filled with various species of a genus, such as the sections of Sempervivums, Sedums, Saxifrages, also of Primulas, Silenes, Aubrietias, Gentianas, Androsaces, etc. Other sections were filled with plants of a uniform height, particularly of kinds of which only a few species exist, while others were arranged in geographical order. The success of the early part of this experiment was such as to induce me to transfer a very large proportion of our alpine plants to the rock garden; and I am happy to say that I have never had cause to regret it. It was often a difficult matter to get such a large collection of alpine plants as existed here kept in proper order, particularly when confined under pot culture, the attention necessary for shifting such a collection being often more than it was possible to undertake at the proper season with a limited staff of men. Unless such re-potting was regularly gone into, the foliage and flowers of each could not be properly developed. In this state species often got confounded together, which is not likely to be the case when all are planted in separate rock-work compartments, yet near enough to be easily compared. The various sections of a rock garden, having the soil prepared specially for the different genera, should be equally drained and enjoy the same exposure. Under such auspices, each individual plant is developed in a more perfect condition than it can possibly be under ordinary pot culture; but, of course, if anyone could devote a great deal of care and attention to a few select favourites, they might develop very superior specimens by pot culture.

The rock garden recently constructed at the Edinburgh Botanic Garden, and still in progress of extension, contains upwards of four thousand compartments, of which 2,200 spaces are filled with various species and varieties of alpine and dwarf-herbaceous plants, besides numerous dwarf, shrubby kinds, from all temperate parts of the globe. The remaining compartments are filled with free-flowering duplicates, placed at uniform distances, to please the eye of those whose taste is for more colour; but even to the botanical 


\section{PLAN I/ROYAL BOTANIC GARDEN EDINBURGH 1870}

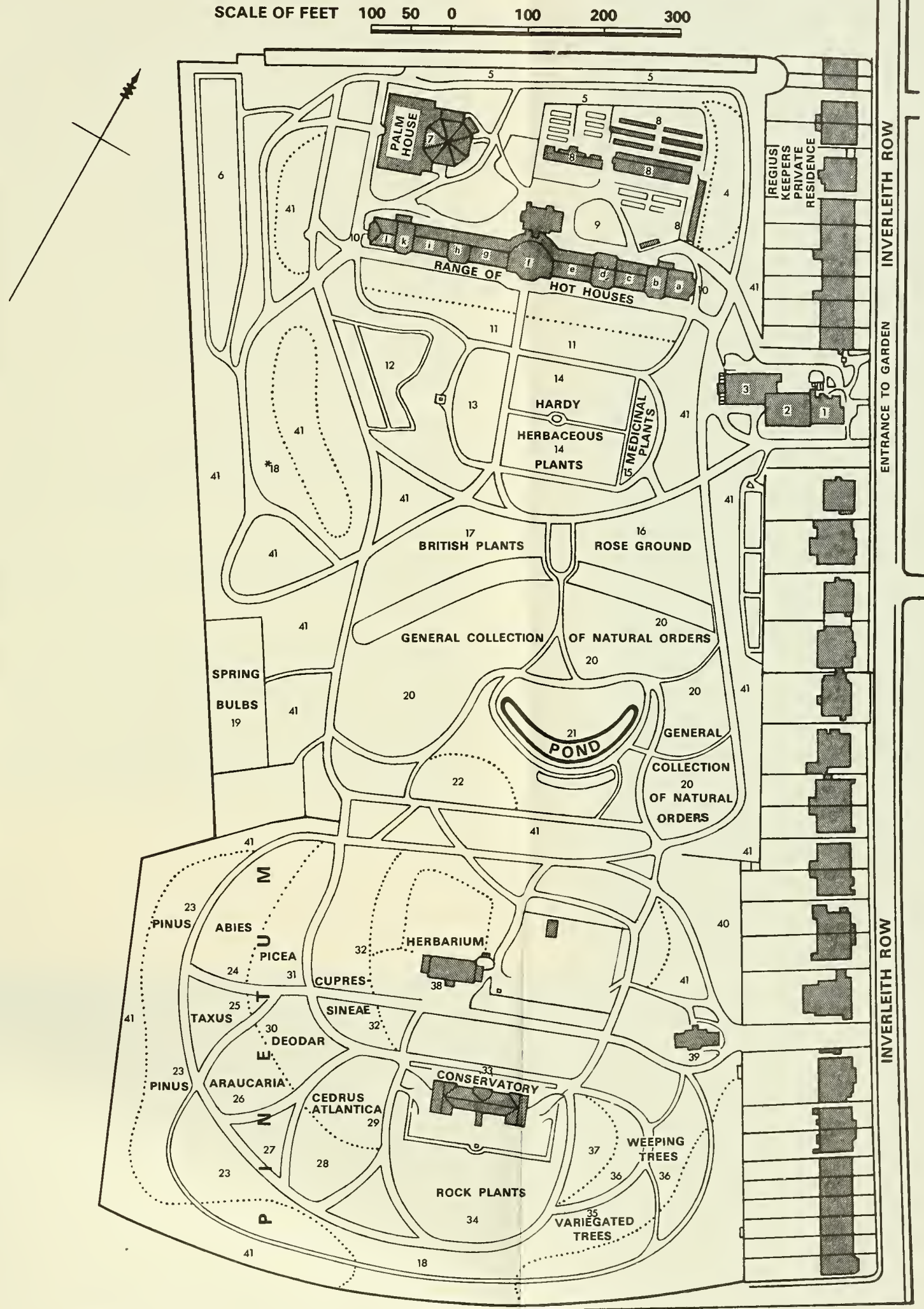


cultivator, such free flowering duplicate masses cannot be otherwise than extremely interesting.

All the angular interstices between the irregular plant compartments are filled with a selection of bulbous plants ... .; amongst them nothing more pleasing than the Iris reticulata, which thrives well in such places and flowers abundantly. It never requires to be lifted except for sub-division.

Many of the larger compartments between the miscellaneous collection of alpines are filled with a selected collection of spring-flowering bulbous plants .... After the spring bulbs have done blooming and cut down, a little good soil is placed on the surface, and the spaces are filled with dwarf annuals, and shallow-rooted summer flowering herbaceous plants .... Such plants are all removed as soon as injured by frost, and the surface of the bulbs is again covered with a little fresh soil, in order to protect the seeds of the annual plants, which rarely start till the bulbous plants are over...

Besides the choice bulbs planted in the general rock garden compartments, a large division is also set aside for a general collection of all the springflowering bulbous plants, both species and varieties, and which are exceedingly interesting during the early months. A division is also arranged for Colchicums, of which the red, pink, white, and variegated contrast well with the varieties of autumn-flowering Crocus, particularly the Crocus speciosus, which succeeds admirably in the stone compartments, making quite a show during the months of September and October.

Large divisions are also appropriated for a selection of monocotyledonous plants, exclusive of bulbs, such as dwarf and herbaceous species of Iris and Yucca; also species of Cordyline, Sporaxis, Helonias, Ophiopogon, Trillium, terrestrial orchids, Convallaria, Uvularia, Narthecium, Tofieldia, Acorus, rare species of alpine Carex etc.

The interstices between the upright stones are filled with varieties of Primula vulgaris, both single and double, which flower abundantly. The double-flowering sorts, which hitherto were of difficult cultivation in the open air, succeed in such places remarkably well. Hepaticas are also admirably adapted for such situations, and, with the Primulas, have a gay appearance during the spring months.

McNab was not the only one who regarded his rock garden as an artistic success as well as an admirable setting for the successful cultivation of many plants. 'F.L.S.', writing in the local press of the time, had this to say:

.... while admiring how well adapted it is for the growth of [alpines], and how kindly some of our choicest rock plants have taken to their new home, one desirable feature, and one only, seems to me not to have been brought sufficiently out, and that is general effect-I would rather say decorative or artistic effect. For as the plan and style of the whole thing is strictly artistic -a new idea of the Curator's own-any attempt to introduce the wild vagaries of rocky pinnacles in miserable imitation of nature would be simply ridiculous. But were any such things as some of the quaintly-carved stones of the old Trinity College Church [which the Lord Provost's Committee 
had been instructed 'to report as to the best means of utilising or disposing of'] .... to be obtained, these, distributed and set up with the taste and skill which the Curator has already displayed, would make this rock garden of his-already so efficient for its proper end-all that the most fastidious could desire in an ornate point of view. Besides it would be the means of permanently preserving some of the most interesting relics of one of our most interesting ecclesiastical edifices from 'going to the wall', and of keeping them in a most fitting place before the eyes of all who are curious in such things. Nay more, I venture to predict that new interest would be lent to them by the tasteful way in which, I feel assured, they would be disposed of.

'F.L.S.' might also have ventured to predict that his suggestion would meet with opposition-as it certainly did. 'E.L.T.' replied:

It would be a monstrous pity to see these stones used for rockeries in the Botanical Gardens, or for other degrading purposes, when they might form, as they did for centuries, a part of a temple dedicated to the worship of God, which would be a memorial, however imperfect, of the ancient church of Trinity College, as well as of the great kindness and paternal care which the Town Council of Edinburgh has ever exercised towards that unfortunate church and parish.

Needless to say, the Trinity College Church stones were not incorporated into the rock work of the rock garden, but the old, well-worn steps and landing of the old School of Arts in Adam Square were added-and so were basalts from the Giant's Causeway and Staffa, large masses of granite and quartz, Black Hecla or Lava stones, and some carved stones which formed part of the old Bank of Scotland buildings at the Mound.

Such then was the Garden which, though lacking the particular character which so many Sino-Himalayan plants were later to give to it, nevertheless was enjoyed by the general public and used for the instruction of a great number of students. In I 874354 students attended Balfour's lectures at the Botanic Garden which were always illustrated by numerous specimens which, in the summer of I873, amounted to 86,000 . On one day in 1873 there had been a competitive examination as well as a lecture and demonstrations, and the specimens cut from the Garden had numbered 7,000. In addition to all this the School of Design at the Royal Institution was also provided with flowers from the Garden. In order to supply these demands and also to ensure the appropriate material for the practical work of the students much greater space was required than was at present available-and not only garden space, but classroom accommodation as well. The shrubs and trees were 
encroaching so much on the ground necessary for the herbaceous plants that the supply of the latter was not only becoming limited but the plants themselves were being injured by shade at the same time. The opportunity for acquiring an extension to the Garden was soon to come.

The construction and planting of the Rock Garden was McNab's last major contribution to the Botanic Garden which he had served with great distinction for thirty years. He died in November I878 leaving a widow, five daughters and one son-William Ramsay McNab, Professor of Botany in the Royal College of Sciences, Dublin. Not only did he achieve real eminence as a cultivator of a wide range of plants, but also some renown as a writer on a diversity of horticultural and arboricultural matters. Much of what he had learned from his practical experience he put on to paper so that others might profit; his transplanting of trees; his retubbing of palms and other large exotic plants; his pruning of conifers and of other shrubs and trees; his ideas on improving Edinburgh-tree planting in the Meadows, West Princes Street Gardens, Queen Street Gardens, St Andrew Square Gardens, the Calton Hill, Royal and Regent Terraces, Gayfield Square and Elm Row, Hope and Bellevue Crescent Gardens, Queen's Park, Moray Place and Royal Circus Gardens; his ideas on the decoration and utilisation of waste places and railway embankments. In his ideas on landscape gardening and town planning he was clearly ahead of his time and his views were accepted without dissent. On one matter however there were many who disagreed with him. In I 872 he was elected President of the Botanical Society of Edinburgh and his Presidential Address on the supposed change of climate in Scotland and its effect on vegetation gave rise to much discussion.

With his death the remarkable reign of the great triumvirate was at an end. 


\section{CHAPTER FOURTEEN}

\section{The Working Men versus The Sabbath Alliance}

OCCASIONALLY IN ITS LONG HISTORY THE GARDEN HAS BEEN the centre of controversy and at no time more so than in the autumn of 1862 when local opinion was divided on the question of whether or not the Garden should be open to the public on Sunday afternoons.

The controversy began when a petition signed by upwards of I4,000 working men of Edinburgh was presented to the Lords of Her Majesty's Treasury praying that the Royal Botanic Garden might be opened to the public on Sunday afternoons after the usual hours of public worship. The petition emphasised that the Garden was established and maintained for the advancement and diffusion of useful knowledge and for the improvement of the people and that it was mainly supported by annual grants out of the taxes of which the industrial classes paid their proportion; that the petitioners were chiefly working men whose labours and domestic duties gave them little or no opportunity to visit the Garden during the working days of the week so that the majority of the Edinburgh citizens received little benefit from it. It was further emphasised that a Select Committee of the House of Commons, in I854, had resolved 'that it was expedient that places of national recreation and instruction, then closed, should be open to the public on Sunday, after the hour of Two o'clock pm, and that, so far as any such places were then closed by the operation of Law, such law should be so far amended as to enable the Lord Chamberlain, or other competent authority, to determine what places should be permitted to be so opened, and for what length of time.' Again, it was argued that the Museum and Gardens at Kew, and the Picture Galleries 
and Gardens of Hampton Court, had for long been open on Sundays, and that, recently, Government had required that the Botanic Garden at Dublin should also be opened; that these institutions were highly appreciated and extensively visited on Sundays by working men and their families and that no kind of recreation and instruction could be more rational than that derived by such people from visits to such places. 'Not only will they thus be led to take wholesome exercise in the open air, but their tastes will be elevated, their manners improved, their knowledge of the works of Nature increased, and their devotional feelings nourished and stimulated.'

Immediately Their Lordships of the Treasury were confronted with a counter-petition from a Society called The Sabbath Alliance which emphasised that the Garden was open gratuitously from six in the morning until six in the evening from Monday to Friday; that on Saturday the Garden remained open until eight in the evening during the summer months for the express purpose of obliging the working classes and their families and that, therefore, these classes had no real difficulty in visiting the Garden, especially on Saturday afternoons; that the working men's petition 'proposed not only violation of the Divine Law, which forbids us from doing our own pleasure on God's holy day, but also a complete innovation on the established usages of the people of Scotland'; that 'were the proposed change adopted, it would have the effect of violating the consciences of most of the men employed in the Garden, and either depriving them of their Sabbath's rest, or removing them from their situations on behalf of others less trustworthy.'

The soundness of the Sabbath Alliance view did not remain unchallenged. To endeavour to prove and illustrate its unscriptural and irrational character a series of letters signed by 'One who values the Lord's Day' was published in THE SCOTSMAN. Likewise were several letters under the signature of 'Aliquis' which argued the position of the Alliance that all 'pleasure-seeking' on Sunday, except recreation absolutely necessary to health, was sinful.

In the meantime the Sabbath Alliance gathered their forces together. They held a public meeting, presided over by the Lord Provost, on 6th October 1862, in Queen Street Hall, Edinburgh, and resolved to send a memorial, subscribed by the Edinburgh public, to the Lords Commissioners. The memorial of close on 34,000 signatures, was duly despatched. The clergy of Edinburgh 
and Leith naturally gave the Alliance their backing. A deputation of them waited on the Lord Advocate on 22nd October and presented a further memorial of I08 clerical signatures:

.... Your memorialists are unanimously and strongly opposed to the proposal which has recently been made to open the Royal Botanic Garden on the Lord's-day, as inconsistent with the law of God, which says, 'Remember the Sabbath day to keep it holy'; as being an invasion of the Sabbath rest of the men connected with the Garden, utterly uncalled for on the ground of public health; the first step in an avowed attempt to convert our Scottish Sabbaths into days of work and amusement, as on the Continent of Europe; and all this aggravated by the circumstance that it is attempted to be done with the open sanction and active co-operation of the Government of this country.

As men charged, in virtue of our office, with the maintenance and guardianship of public morals, and convinced that a diminished regard for the Sabbath tends to relaxation of all religious and moral principle, we feel that we cannot too strongly resist the first step in such a disastrous course; and we appeal to Your Lordship as the public organ of the Government of this country, as one of the representatives of Edinburgh, and as thoroughly acquainted with the general state of feeling in Scotland, to make such representations as shall prevent the Government from adopting a course which would be offensive to the religious convictions of the community and injurious to the interests of religion and morality.

Similar memorials were adopted by the Commission of the General Assembly of the Free Church of Scotland, by the Edinburgh Presbytery of the Established Church of Scotland, and by the Edinburgh Sabbath Teachers' Union. Later the Sabbath Alliance was strongly supported by Professors in the University of Edinburgh, including Balfour the Professor of Botany, Fellows of the Royal and other learned Societies, Members of the Scottish Bar, of the Medical Colleges, and others; '.... the opening of the Garden is peculiarly uncalled for in Edinburgh where, for those who desire it, there are already ample means of relaxation in the open air on Sunday-in the Queen's Park, the Meadows, the Calton Hill, Bruntsfield Links, and other beautiful and spacious places of resort-all nearer to the houses of the working classes, on whose behalf the opening of this Garden is chiefly asked, and which can be and are freely used without exacting Sunday labour from anyone.'

The Lords of the Treasury replied to the working men's petition on Ist November:

Taking into view the novelty and seriousness of the question as it is regarded at Edinburgh, with the strong feelings and decided opinions on the subject 
of the observance of the Sabbath which prevail there, and also having regard to the present season of the year, my Lords deem it proper to postpone any decision until the spring shall be near at hand, when their Lordships will have a further opportunity of receiving information as to the prevailing wishes of the community on the subject.

For the rest of the winter and into the spring both parties strove hard for their causes and in March I863 were able to submit their petitions to the House of Commons. That which prayed for the Sunday opening of the Botanic Garden after the hours of Divine Service was signed by 36,897 adult males; the other by 48,522 men, women and boys. And on 8th June the matter was debated in the House. Strangely enough, the motion for the opening of the Garden was not moved by a Scots MP but by the MP for Galway, $\mathrm{Mr}$ Gregory, who had successfully initiated the opening of the Dublin Botanic Garden on Sundays. Various MPs spoke in favour of the motion-and various MPs spoke against it. The speech of Lord Palmerston, then in his eightieth year, probably carried the greatest weight:

If I were to vote according to my own opinion on the merits of the question in itself, I should give my support to the motion of my hon friend the Member for Galway. (Loud Cheers.) Of course, in the abstract, I can see no harm, but rather good, in doing that in Edinburgh which has been already done in other capitals-that is to say, opening a place, ever so small or large, for purposes of recreation (Cheers.) But I think in the present case there is another consideration to which the House ought to attend, and by which they ought to be guided-namely, that a real, sincere, and honest feeling on the part of the people of Scotland exists with regard to this question. (Cheers.) I hold that, without some very grave and important reason, you ought not to do violence to public feeling; and that public feeling in Edinburgh and Scotland is against the opening of these Gardens on Sunday evenings is, I think, an indisputable fact. We have been told tonight that there are over 64,000 signatures against the opening and 30,000 in its favour. Why, last year, every morning I used to get petitions, coming from almost every parish in Scotland, against the opening of these Gardens. It is quite true that these petitions had a very strong family likeness-(Cheers and laughter)-but still the striking identity of expression showed such identity of feeling that it really gave weight to these opinions, because it showed that in every part of the country the same opinions prevailed. Whatever might have been the origin of those petitions, they would not have come to me if they did not express the feelings and sentiments of those from whom they proceeded. (Hear, hear.) Now, is there any necessity-any strong and paramount reason-for doing violence to public feeling? It has been already stated by my right honourable friend the Lord Advocate that Edinburgh, of all towns in the world, possesses in its neighbourhood the amplest oppor- 
tunities for air, exercise, and recreation. Arthur's Seat, the Queen's Park, and all the outlets in every part of the town afford the working classes much greater cnjoyment than this small Garden can possibly yield; indeed, I think the great desire expressed to enter it must proceed from the same feelings which forbidden fruit excites in the minds of men. (Hear, hear, and laughter.) This Garden is the smallest thing imaginable; in extent it is only about I6 acres, and the centre is occupied with flower beds and plants intended for scientific instruction. I venture to say that if the 34,000 persons who are so anxious to enter these Gardens were all to agree to go there some afternoon they would find considerable difficulty in getting in, and if they did all succeed in entering, the air would not be by any means enjoyable. (Much laughter.) I think there is no necessity for acceding to the motion of my hon friend. The hon gentleman says the feeling of Scotland is changing in this matter, and that in the course of no distant time the opinion of the majority will be in favour of opening these Gardens. Well, I say, let us wait till that change takes place. (Hear, hear.) I am of opinion that this-I will not call it prejudice, for it is not prejudice, but strong religious feeling, is honourable, and ought to be respected. (Hear, hear.) I am inclined to think that, owing to change of circumstances, the same importance is not attached in Scotland to those strict observances which some time since was attached to them; and in the course of a few years we shall probably find that in the general opinion of Edinburgh and of Scotland there will be no harm in opening these Gardens. Wait till that happens; act in accordance with public opinion and in a spirit of deference to it; and do not, by hasty adoption of a principle to which Parliament in the abstract might be disposed to lend its sanction, offer violence to ancient and honourable feelings conscientiously entertained. (Cheers.)

The House divided; I07 voted for Mr Gregory's motion and I23 against. Twenty-eight Scottish Members were present at the division and twenty-two voted with the majority. Thus was the motion lost by sixteen votes.

Not for another quarter of a century were the working men to gain their point, and even then they had the Sabbath Alliance to contend with. 


\section{Interlude to}

\section{Parts Three and Four}

TO THE CHAIR OF BOTANY IN THE UNIVERSITY OF GLASGOW, which Robert Graham vacated when he succeeded Rutherford in Edinburgh, William Jackson Hooker was appointed in 1820 . He had no experience of Garden administration, no experience of teaching, no experience of lecturing. Nevertheless he was an outstanding success from the first. Largely through his initiative the Glasgow Garden increased enormously in stature through the new plants, many of them new species, which he assembled from far and wide. In I82I the number of species growing in the Garden was about 9,000, whilst in $1825 \mathrm{I} 2,000$ were estimated to be there; an increase of between 300 and 500 continued for several years.

As with Graham in Edinburgh, so with Hooker in Glasgow, field botany figured prominently in his teaching. He led excursions to places of botanical interest within the neighbourhood of Glasgow and once a year engaged in a more ambitious project in the Highlands of Scotland, usually in the Breadalbane range of mountains. Just as Hutton Balfour was later to write text books for his students in Edinburgh, so did Hooker in Glasgow. His first work to meet the requirements of his students on their excursions was the FLORA SCOTICA of I82I which at last revealed to the botanical world the great interest of the Scottish mountain flora. His next work was of much greater significance and was to meet the demands of a much wider public; the BRITISH FLORA was published in I83I and in the course of the next thirty years eight editions were to appear. Previous to the BRITISH FLORA, the written records, with one or two important exceptions, had aimed chiefly at indicating the locality where any particular plant was to be found. But the BRITISH FLORA was meant to do more than this, for in the preface Hooker very significantly avows himself 'rather anxious to indicate the range of the species than the precise spot where any one is found'. Thus British botanists were becoming alive to the interests of the distributional problems of their native plants. 
In this Hooker was not the pioneer. The honour falls to Nathaniel Winch, who, in 1819 , read at a meeting of the Literary and Philosophical Society in Newcastle upon Tyne a remarkable paper entitled An Essay on the Geographical Distribution of Plants through the Counties of Northumberland, Cumberland and Durham.

After briefly discussing the topography of the country, the indigenousness or otherwise of some of the trees such as oak, elm, beech, ash, aspen and pine, the exotics which succeed in woods and plantations, and the past and present distribution of agricultural land, Winch divides the plants of the three northern counties into certain groups: those plants which have reached their northern limits in this part of the kingdom; those which have reached their southern limits; those which are found on the sea-coasts, and again on the mountains; rare species, natives of Switzerland; rare species, natives of Lapland; rare species, natives of both these countries; rare species, natives of neither of these countries; etc.

This analysis of a particular portion of the British flora from a phyto-geographical point of view is something quite new. Likewise is William MacGillivray's ecological and altitudinal study of the plants in an area in Aberdeenshire-Remarks on the Plienogamic Vegetation of the River Dee, published in 1832. MacGillivray describes the alpine vegetation and traces it downwards from the mountain tops as it mingles with the vegetation of the valleys. Gradually descending, he lists the plants which creep down the mountains and those of lower situations which struggle upwards, noticing their habitat and any changes in their vegetative and reproductive condition, until he reaches the heaths and moorlands and finally the valleys.

Both Winch and MacGillivray expressed the hope that their fragmentary studies would stimulate others to prepare a complete picture of the geographical distribution of British plants. In this they were not to be disappointed for shortly after the publication of MacGillivray's paper, in the same year of 1832 in fact, there was printed for private distribution a small volume entitled OUTLINES OF THE GEOGRAPHICAL DISTRIBUTION OF BRITISH PLANTS. The author was Hewett Cottrell Watson, friend both of Graham and of Hooker.

Watson had been a student in Edinburgh and had taken great interest in the botanical lectures of Professor Graham whom he accompanied on an excursion to Sutherland. Graham introduced him to William Hooker and he was thereafter a frequent companion 
of Hooker and his students on many of their Highland excursions. His writings on the geographical distribution of the British flora covered a period of over 40 years and the OUTLINES is his first botanical publication.

After the OUTLINES, for nearly a quarter of a century Watson was compiling what was to be his magnum opus - CYBELE BRITANNICA, or British Plants and their Geographical Relations a work of four volumes the first of which appeared in I847 and the last in I859. 'Cybele' was the mythological name of the Goddess who was supposed to preside over the productions of the earth and Watson proposed this term for an account of the geography of the plants of any particular country as a parallel to the term 'Flora' which had for so long been used for a systematic description of the orders, genera and species of any given region. The CYBELE is a systematic treatise on the geographical distribution of the plants of the counties of Britain and embodies the author's plans for registering the details of plant distribution.

In I860 Watson published a supplement to the CYBELE in which he traced the horizontal range of British species through the 38 sub-provinces into which he had divided Britain. A mass of additional material which he harvested in the years following the publication of the last volume of the CYBELE formed the text of the three volumes of the COMPENDIUM OF THE CYBELE (1868-70) wherein he worked out the distribution of the species beyond the borders of Great Britain. Lastly, in the two volumes of TOPOGRAPHICAL BOTANY (1874-75), with a second edition in I883, the horizontal distribution of the species is traced through the II 2 vice-counties into which he had further divided his original sub-provinces. This work was compiled from a great mass of material for which many botanists were responsible, including of course, in Scotland, the Professors of Botany in the UniversitiesGeorge Dickie of Aberdeen, author of the BOTANIST'S GUIDE TO THE COUNTIES OF ABERDEEN, BANFF AND KINCARDINE (1860), Hooker and Walker-Arnott in Glasgow, Graham and Hutton Balfour in Edinburgh.

Sir William Jackson Hooker (he had been knighted in 1836) left Glasgow in I84I for Kew, there to develop the great Herbarium and Library, and the general layout of the Gardens, Glasshouses and Museums. His successor in Glasgow, John Hutton Balfour, held the Chair only for four years before being appointed to Edinburgh in I845. Hooker's son, Joseph Dalton Hooker, also a 
candidate for the Edinburgh Chair in I845, as we have seen was passed over. Instead of becoming Keeper of the Garden and Professor of Botany in Edinburgh, he became Botanist to the Geological Survey and, though he held this post for only eighteen months, a series of valuable papers on fossil botany was the result. He spent the years I847- 5 I in India and, as a consequence, published hiS RHODODENDRONS OF THE SIKKIM HIMALAYA (I849-5I) and the Himalayan Journals (I854). He became Assistant Director to his father at Kew in 1855 , the year which saw the appearance of volume one-and the only volume-of FLORA INDICA of Hooker and Thomson. In I865, the year following the publication of the first volume of his HANDBOOK OF THE NEW ZEALAND FLORA, he succeeded his father and was Director of Kew until I885, publishing during this period THE FLORA OF BRITISH INDIA, THE STUDENTS FLORA, and, in collaboration with George Bentham, GENERA PLANTARUM; and he founded INDEX KEWENSIS which provides an authoritative list of all the names of plants that have been used, giving the author of each and the place of publication. The list of his published works extended from I837 to I9I I and treated of many aspects of botanical science in all of which he excelled.

The cumulative result is that he is universally held to have been, during several decades, the most distinguished botanist of his time. He was before all things a philosopher. In him we see the foremost student of the broader aspects of Plant Life at the time when evolutionary belief was nascent. His influence in that stirring period, though quiet, was far-reaching and deep. His work was both critical and constructive. His wide knowledge and keen insight, his fearless judgment, were invaluable in advancing that intellectual revolution which found its pivot in the mutability of species. The share he took in promoting it was second only to that of his life-long friend Charles Darwin. ${ }^{\mathbf{I}}$

Such was the judgment of F. O. Bower, who might well have held the Chair of Botany in Edinburgh and who was to fill the Glasgow Chair with great distinction for many years. And such was the man the Lord Provost of the City of Edinburgh was anxious to appoint to the Edinburgh Chair of Botany in I845. It is tempting to speculate on what might have happened to botany in Edinburgh had Joseph Hooker's candidature not been passed over in favour of that of John Hutton Balfour. How much poorer would the world

I F. O. Bower in F. W. Oliver, MAKers of BRItish Botany, (1913), p.323. 
of botany have been if his candidature had been successful? Would Hooker have become the great traveller and geographer, geologist, morphologist, systematist, philosophical botanist and administrator that he proved himself to be?

Likewise is it tempting to speculate on the path which botany in Edinburgh-and elsewhere-would have taken if Robert Brown had severed his connection with Sir Joseph Banks, had resigned his post as Librarian to the Linnean Society and succumbed to the entreaties of Patrick Neill and others, and had succeeded Rutherford in the Edinburgh Chair. What would have been the trend of Brown's future work had he been induced to come to Edinburgh? Most certainly vastly different to what it proved to be, for during the twenty-five years during which Graham, in Edinburgh, was practising medicine, teaching in the Hospital, teaching botany, confuning his research to systematic botany and describing new plants for the вОтANICAL MAGAZINE and other journals in the process, encouraging field botany, instituting the system of student essays, as well as developing the Botanic Garden, Brown was interpreting the morphology of the flower in such great groups as the grasses, the asclepiads, the orchids, the Rafflesiaceae and others, was showing the fundamental distinctions between the Dicotyledons and the Monocotyledons and between the Gymnosperms and Angiosperms, and thus was making important discoveries in the domain of morphology and systematic botany which did so much to overthrow the Linnaean System and to substitute for it a more natural system of classification. Moreover it was Brown who discovered the existence of the cell nucleus-one of the great biological triumphs of the I9th century-which led to the formulation of the concept of the cell as the unit of organic life.

The cellular structure of wood and cork had been discovered in the I 7 th century and the term 'cell' had been first applied by Robert Hooke. It was left to the botanists of the Igth century, using finer microscopes, to discover much of what was within the rigid walls of the cells. Brown's discovery of the nucleus in I83I was taken up by M. J. Schleiden, Professor at Geneva, who in 1838 published his treatise BEITRÄGE ZUR PHYTOGENESIS which is regarded as the foundation of the cell theory, which gave birth to the science of cytology, and which has exerted a great subsequent influence on plant and animal biology. Schleiden's work stimulated such workers as Von Mohl at Tübingen and Naegeli at Munich, who quite independently distinguished the cell wall from the cell contents, 
recognised the protoplasm-the word was first used by Von Mohl in 1846-and prepared the way for the physiological renaissance of Sachs and his school at Würzburg.

Remarkably significant in botanical history as were the years of Graham's tenure of the Edinburgh Botany Chair, the thirty-four years during which Hutton Balfour reigned in Edinburgh were even more so. The year I859 was the momentous one which witnessed the publication of Darwin's ORIGIN OF SPECIES and the Darwinian viewpoint which did not regard the plant kingdom as a collection of more or less static units grouped together in immutable species, each one being created and arranged by the Creator in a master plan, but as a collection of changing things, interacting with their environment and constantly evolving new forms in response to environmental change, greatly influenced all branches of botanical thought. But apart from the ORIGIN OF SPECIES there were other important Darwinian works during this period; FERTILIZATION OF ORCHIDS (I862), INSECTIVOROUS PLANTS (I875), CROSS AND SELF FERTILIZATION IN PLANTS (I876), and Movement in plants (I880).

Darwin apart, there was de Bary in Strassburg, engaged on his great work on comparative anatomy, the COMPARATIVE ANATOMY OF PHANEROGAMS AND FERNS of 1877 , a work which paved the way for Van Tieghem's so-called theory of stele on the basis of comparative morphology and phylogeny. Working in France, Van Tieghem and his students concluded that root and stem are essentially similar because each possesses a central core, or stele, surrounded with a cortex. De Bary was also deeply engrossed in the fungi, defining the terms parasitism and saprophytism, and working on his MORPHOLOGY AND BIOLOGY OF THE FUNGI which appeared in 1884, the year Hutton Balfour died. In France the brothers Tulasne were investigating the development of the fungi and publishing their great work SELECTA FUNGORUM CARPELOGIA between I86I and I865. Incidentally, Pasteur too was working during this period. There was the Leipzig bookseller, Wilhelm Hofmeister, who, though lacking a university education, was destined to hold two important university posts; in 1863 he was appointed Professor of Botany and Director of the Botanic Garden in Heidelberg, and in 1872 he succeeded Von Mohl in Tiubingen. He demonstrated the presence in the plant kingdom of two alternating generations, a sexual and an asexual one. Others were to show that in certain plant groups one of these generations 
is missing; the American W. G. Farlow demonstrated, in I874, the phenomenon of apogamy in the ferns, whereby the sexual process in the life-cycle is cut out, and in 1877 Pringsheim in Berlin conclusively showed in the mosses the condition known as apospory whereby the asexual or spore stage is omitted from the life-history.

In the field of plant physiology Sachs was concerning himself with the importance of root hairs and with the phenomenon of water movements in plants; in France, Jean Baptiste Boussingault was conducting experiments in the assimilation of nitrogen by plants; and two Englishmen, J. B. Lawes and J. H. Gilbert, in I843 at Rothamsted, were conducting field experiments to show the effect of chemical fertilizers on the land and thus were founding the experimental station which was to solve many problems of soil science and plant nutrition.

In the field of plant geography, there were three workers who fully understood the significance of the Darwinian evolutionary concepts; August de Grisebach in Göttingen, who was defining types of physiognomy of vegetation in respect of climate and who published his DIE VEGETATION DER ERDE in I872; Asa Gray in America, who was surveying the characteristics of the North American flora and defining its origin and affinities with other continental floras; and J. D. Hooker, Darwin's greatest and closest confidant, who was showing immense interest in geographical distribution and elucidating problems of endemism and who, in the same year as the ORIGIN OF SPECIES, when working on his collections from the Antarctic, had expressed his belief in the mutability of species. And in the field of physiological plant geography-or what would now be called ecology-there were E. Warming in Denmark, A. F. W. Schimper and H. Schenck in Germany-and others.

Thus, while exciting new ideas and theories anatomical, morphological and physiological, were being developed in Europe, botany in Britain was being dominated, in large measure, by the systematists, Brown and Hooker especially, and outside systematic botany and plant geography, the science in Britain virtually was dead. That the ideas from Europe finally spread among British botanists was due in the main to de Bary in Strassburg, to Sachs in Würzburg, and to the biologist T. H. Huxley in South Kensington, and some of Huxley's demonstrators.

In the early 1870's, at what is now the Royal College of Science, Huxley had given a memorable course in elementary biology 
consisting of a daily preparatory lecture followed by personal observation by each student. In 1872 he was assisted in this by William Turner Thiselton Dyer, who, the following year, was persuaded by Huxley to organise a similar course in botany to science teachers, a course which continued for several years; Thiselton Dyer, who was to assist in the translation of Sachs's TEXT BOOK OF BOTANY (I875); who in 1875 was to become Assistant Director at Kew, and Director in 1885 ; who, during the next twenty years, was to develop the Gardens at Kew, build the Temperate House, rebuild nearly all the glasshouses, extend the Herbarium, enlarge the Museums, do all possible to strengthen the relationship between Kew and the Colonies, and, not least important, equip the Kew Jodrell Laboratory and encourage there Horace Brown's work on photosynthesis, Walter Gardener's work on protoplasm, Scott and Williamson's work on fossil plants, F. O. Bower's work on ferns-and much else.

In I875 Thiselton Dyer's demonstrator at South Kensington was Stanley Vines, then an undergraduate at Cambridge (where the Professor, Charles Cardale Babington, was concerned only with the detailed systematics of the British and European floras) and who later was to study on the Continent with Sachs and de Bary, demonstrate in Cambridge many objects described in Sachs's тЕХт воОк and not seen in England before, pioneer work on the proteolytic enzymes, and become Professor of Botany at Oxford. In I876, Thiselton Dyer had an assistant additional to Vines, Harry Marshall Ward, who was enthralled by the new laboratory teaching, 'The Cause' as he called it, who had also studied with Sachs and de Bary, and who, after holding various posts, was appointed to the Chair of Botany in Cambridge, there to develop a modern school of botany. F. O. Bower, who, with Ward, had also been a student under Vines at Cambridge, and who later was also to work in Strassburg and Würzburg, also demonstrated at South Kensington before becoming Professor of Botany in Glasgow.

One other fell under the spell of Huxley, not at South Kensington but in Edinburgh, in 1875 , when Huxley was acting as DeputyProfessor of Natural History whilst Wyville Thomson was absent on the CHALLENGER Expedition; he fell too under the spell of de Bary (the winter of $1877-78$ ), and under the spell of Sachs (the winter of I878-79)-Isaac Bayley Balfour, who was to carry the New Botany, 'The Cause', from Glasgow to Oxford, and thence to Edinburgh. 


\section{PART FOUR}

\section{Under the Crown}

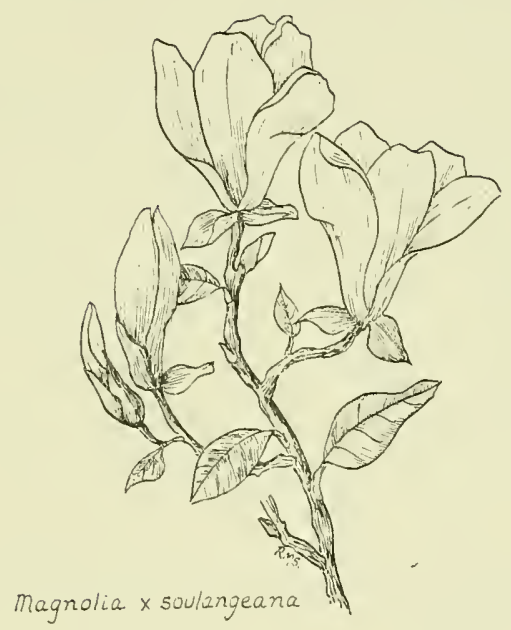





\section{(5)}

\section{CHAPTER FIFTEEN}

\section{Alexander Dickson and his Curators}

FOR SOME YEARS BEFORE HE RETIRED, JOHN HUTTON BALFOUR had been worried by the cramping effects of the small acreage of the Botanic Garden which did not give him scope for the development of an arboretum which he conceived to be necessary now that the science of Arboriculture was gaining prominence, nor scope for the cultivation of the vast number of specimens, mostly herbaceous, which were required for the teaching of the students. The opportunity for acquiring an extension to the Garden came towards the end of 1874 when the grounds of Inverleith (some 28 acres in all) which adjoined the Botanic Garden on the west side and which were unoccupied by buildings were offered to the Government by the Fettes Trustees, to whom they belonged. The Trustees asked the sum of $£, 35$ feu per acre.

Straightway, Balfour began to canvas on behalf of the Garden extension, strongly urging the First Commissioner of Works to bring the matter to the notice of Her Majesty's Treasury, and seeking the support of the Lord Provost and Town Council of the City of Edinburgh as well as the members of various scientific societies. The Botanical Society of Edinburgh promptly reacted by addressing the following letter to the Honourable Lord Henry Gordon Lennox, First Commissioner of Her Majesty's Works, on Igth November 1874:

The Botanical Society of Edinburgh having learned that an opportunity is now presented of making an addition to the Royal Botanic Garden on its western boundary so as to form an Arboretum, respectfully beg to urge strongly upon the Government the great desireableness of steps being taken to secure the grounds which may now be acquired from the Fettes Trustees. 
The acquisition of this property, the soil and structure of which are highly favourable for the purposes of an Arboretum, will materially promote the study of Arboriculture, and will extend the capabilities of the Garden as a school of Science. Means of increased instruction will thus be afforded to the rapidly increasing students of Botany and valuable opportunities for the practical study of Arboriculture which will be open to Foresters and others, and among the rest to those young men who are preparing for Government service in taking charge of the Forests of India and the Colonies, and who at present are obliged to repair to the Continent for acquiring the requisite practical knowledge, and sometimes fail to receive it even there. It is of great importance that the ground be now secured to prevent it from being occupied by buildings, which, if erected, would cause great injury to the present Garden by smoke and otherwise. Moreover the removal from the ground in question of the trees which now form an important protection to the Garden from the strong westerly winds, would be a very serious calamity. In these circumstances the Society trust that the Government will take steps to secure the ground now offered. They urge this measure the more readily, that, after the cost of purchase and putting the ground in order, the annual expenditure for an Arboretum will be much less than for ground applied to the other purposes of a Botanic Garden.

On somewhat similar lines, James Falshaw, the Lord Provost of Edinburgh, also addressed the First Commissioner of Works.

The Treasury replied in January I875 to the effect that, although it appreciated that the proposed addition of an Arboretum to the Botanic Garden would be equivalent to providing Edinburgh with a park of an interesting and instructive character and would also preserve to the citizens of Edinburgh one of the most beautiful and effective views of the City, it regarded these objects as 'local and not imperial'. At the same time the Treasury intimated that, if Edinburgh imitated the example of London which had allowed itself to be rated for the original acquisition of Victoria Park, and other recent acquisitions to the London parks, the Government would undertake the annual expenditure necessary for supporting the Arboretum.

The onus was now with the Lord Provost who, fortunately for Balfour, was anxious to secure the additional land. 'I am convinced of one thing', he wrote to Balfour, '-viz, that there cannot be a more desirable thing for the interests of Scotland and for keeping up the finest view of Edinburgh than the purchase of this ground. I do so wish that I could impress my fellow citizens with my views -but how? that is the question. Surely some power will come up to my help'. Presumably some power did come to the Lord Provost's aid, for he carried his Council with him on all but two 
points; the purchase of the house on the estate and the fencing in of the ground if, and when, the estate was purchased. All was in order when Government agreed to take over Inverleith House as the official residence of the Regius Keeper, and to provide the necessary fencing.

The agreement, between the Town Council of Edinburgh, the Commissioners of HM Works, and the Fettes Trustees and Mr Rocheid, was drawn up in I876 and forms an interesting and historical document which is reproduced in the Appendix.

In this fashion, the City agreed to purchase the lands of Inverleith in 1876 , to transfer them to the Government in March of the following year, so that they would then be maintained by the Government as a scientific Arboretum and as a place of recreation for the public. The Fettes Trustees for their part agreed to provide the appropriate access roads to the Arboretum.

On all matters but one-his occupation of Inverleith HouseBalfour was highly pleased. He owned the house where he was at that time living, 27 Inverleith Row, and neither he nor Mrs Balfour was anxious to move into Inverleith House, especially as it meant Balfour losing his house allowance of $f_{\mathrm{I}} \mathrm{I} 2 \mathrm{O}$. He recommended that, instead of being made into his official residence, Inverleith House be converted into a Museum to complement the Arboretum. He pointed out that the Arboricultural Society was making large collections of specimens, illustrating the characters of the wood of trees, which he was certain the Society would deposit in such a Museum. In addition he would also deposit his own great collection of woods from India and elsewhere. "The constitution of a living Arboretum with a Museum of woods used for timber and for economical purposes in various parts of the world would indeed be a great advantage to the Edinburgh Botanical School and would be prized by all classes of the community.' 'I With a new Museum, the present small one, with the other buildings, could be made available for classroom purposes and for a physiological laboratory and would thus solve the problem of the present shortage of classroom accommodation. This was an eminently sound suggestion in which presumably the Office of Works was not interested.

The house was partially destroyed by fire on Ist August I876, and no doubt Balfour appreciated the fact that now, probably, he would not be called upon to occupy it.

I Balfour in a letter to HM Office of Works, 27th October 1876. 
Having accomplished his object of substantially increasing the area of the Botanic Garden, Balfour's thoughts were now on retirement, and in 1879 he wrote his last annual report of the Garden. The fencing of the Arboretum had been completed by means of a low stone parapet and malleable iron railing of simple design and $8 \mathrm{ft}$ high. Even so, the railing would not be very effective against the entrance of interlopers until a stout hedge had been established inside the railing. Only one entrance to the Arboretum was planned and this would be situated about the centre of the new west road leading from Inverleith Place to St Bernard's Row, Stockbridge. The approach to the entrance would take the form of a wide semicircular sweep with ornamental gates swung to freestone pillars which would be capped with stone globes. Though the refitting of Inverleith House for the Regius Keeper was all but completed, nothing had as yet been done in the laying out of the Arboretum grounds. A plan for walks in the Arboretum had been submitted to Government, and when this had been finally agreed and the ground levelled, the plan for grouping the trees could be determined and planting begun. In this latter the Regius Keeper would have the support of John Sadler, who had succeeded the lamented James $\mathrm{McNab}$ as Principal Gardener.

Balfour emphasised that the quantity of plants required for instruction in the Garden was very great and that the Regius Keeper supplied with specimens the largest botanical school in Britain. In the summer of I 878 the lectures in the Garden had been attended by 4I2 pupils, including students of medicine, science and pharmacy, as well as general students. Besides lectures, demonstrations were given in the planthouses. The number of fresh specimens of plants used for lectures and demonstrations during the session of I878 had been 47,280 , more than a hundred for each pupil.

The amount of instruction given at the Garden was very considerable: lectures every Monday, Tuesday, Wednesday, Thursday and Friday, at $8 \mathrm{am}$, from the beginning of May until the end of July; competitive examinations for honours; demonstrations on Fridays from 9 to $10 \mathrm{am}$; classes in practical botany on Mondays, Tuesdays and Wednesdays at $9 \mathrm{am}$; study at any time during the day in the Museum and Herbarium room. In addition, excursions and demonstrations in the field were held on Saturdays. Prizes were awarded for competitive examinations, herbaria, essays, dissections, models and microscopical preparations. 
Balfour complained that the annual Government allowance of $f_{\mathrm{I}}, 400$ was not adequate for the purpose of satisfactorily maintaining the Garden, the number of men and boys not being sufficient to keep the Garden in a thoroughly efficient condition and under proper surveillance. The annual sum for Garden purposes should be raised to $f_{1}, 700$ or $f_{1}, 800$-quite independent of the allowance which must be granted for the Arboretum.

One of the most important points for consideration on the part of the Office of Works, Balfour maintained, must be the building of a new classroom capable of seating an audience of 400. This want of accommodation had been complained of for the past four years, and two signed petitions on the subject had been submitted to the Government. Some of the planthouses in the Garden were largely in a state of decay and required renewal. A propagating house and hot beds as well as an aquarium and a fern house were required. The funds of the Garden were not sufficient for the purchase of plants, which had therefore to be acquired by exchange from other gardens in many parts of the world.

Such was the situation when Hutton Balfour retired in 1879 and when Alexander Dickson succeeded him in I880.

It is clear that there was a strong body of opinion in favour of Isaac Bayley Balfour succeeding his father, for in March 1879 the following letter was addressed 'To the Right Honourable and Honourable The Curators of Patronage of the University of Edinburgh':

.... Dr Balfour has taken advantage of the exceptional opportunities for the study of botanical science which have been open to him in this country and on the Continent. He has thus been able not only to make himself broadly and thoroughly acquainted with botanical science, but also to devote much effectual labour to the investigation of special departments.

The great importance of Cryptogamic Botany in relation to epidemic and septic disease is admitted by all scientific observers. In qualifying himself for teaching this particular branch, Dr Balfour has had the special advantage of working under Professor de Bary and other distinguished authorities, and has, further, had the advantage of studying medicine under the guidance of those physicians and surgeons who have been most distinguished in applying a knowledge of this subject to practical medicine.

As Botanist to one of the expeditions for observing the Transit of Venus, he studied the flora of the Mascarene Islands, and his monographs are likely to become the standard source of information upon the Botany of this interesting region.

We are able to state that, as Assistant to Professor Huxley and Sir Wyville Thomson, and as Substitute during two sessions for the Professor of Botany, 
Dr Balfour has proved a popular and enthusiastic teacher, and has shown himself to possess a remarkable gift of lucid exposition.

Taking into consideration Dr Balfour's natural ability, his knowledge of Botany, his love for, and devotion to science, we believe that his appointment to the Chair so worthily filled for many years by his father, would give great satisfaction, and tend to increase the reputation of our University.

The letter, signed by 289 graduates of the University of Edinburgh holding important posts in various branches of medicine and surgery throughout Great Britain, however, was of no avail.

The finances of Hutton Balfour's various appointments had been curiously complicated. $\mathrm{He}$ had been appointed by the Town Council to the Professorship of Medicine and Botany in the University, and by the Crown to the Regius Keepership of the Botanic Garden with the title of Regius Professor of Botany. In I 862-63 the University Commission gave as salary to the University Chair of Medicine and Botany $^{6} 60$ per annum compensation (for graduation fees) in addition to $£ 40$ received from Leith Harbour Dues, making $f_{\mathrm{I}} 0 \textrm{o}$ in all. But the University Commission also took the fioo given by the Crown to the Keeper of the Garden and added it to the emoluments of the University Chair to make $f^{200}$. The Keepership of the Garden was thus deprived of any salary. In I867 an Annual Grant of $\mathcal{L}$ I2O was allowed to the Regius Professor and Keeper of the Garden, as house rent. But when in I 876-77 Inverleith House was purchased by the Crown and the surrounding land by the City of Edinburgh, and when the Crown undertook to maintain the land as a scientific educational institution, and the Regius Professor and Keeper received Inverleith House as an official residence, the Annual Grant for house rent was stopped.

The financial arrangements pertaining to Dickson's appointment were quite the reverse of Balfour's. In Dickson's Crown Com-

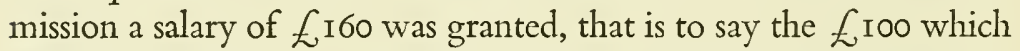
had been attached to the Regius Chair and Keepership in 1820, when Robert Graham was appointed, and which the Universities Commission had taken away to add to the emoluments of the Curatorial (the patronage of the Town Council by this time had been transferred to the Board of Curators) Chair of Botany, was again granted; and the $f_{60}$ which, as compensation for graduation fees was strictly attached to the University Chair of the Curators, was appropriated by the Government to the Regius Chair and Keepership. Therefore, had there been two different occupants of the Chairs, one, the Curators' Professor, would have received only 
f40 salary, and the other, the Crown Professor, would have had fr6o a year in salary. Thus, a condition of affairs came to pass quite the reverse of what the Universities Commissioners established in $1862-63$.

A further interesting point about Dickson's appointment was that the link between botany and medicine was still further weakened, for medicine was not included in the title of Dickson's Chair. Even so, one whose primary training had been in medicine succeeded Hutton Balfour.

Dickson (Plate IXa) was born on 21st July I 836, in Edinburgh. He was the second son of David Dickson, of Hartree in Pecblesshire, and by the early death of his elder brother he became the heir to, and finally the owner of, the estates of Hartree and Kilbucho. After receiving his early education at home, he studied at the University of Edinburgh and graduated in medicine in 1860 , previously having studied in Würzburg and Berlin. During his student days in Edinburgh he manifested a love of botany and was one of Hutton Balfour's most distinguished students, gaining one of Balfour's Gold Medals for a thesis The Development of the Caryophyllaceae, an abstract of which was published in the TRANSACTIONS of the botanical society of edinburgh. Although he had qualified himself to practise medicine, his heart was in botanical studies and, in the hope that some suitable botanical post might present itself, for some time he delayed taking any steps to begin the practice of medicine. However, at the beginning of 1862 he was, as he himself wrote, 'at last reduced to the dire necessity of announcing himself as a servant of the public by way of a door plate'. But before any practical issue could come of this the botanical post materialised for in I862 he was called to Aberdeen to act as Deputy to the Professor of Botany, George Dickie, who at that time was in poor health. In Aberdeen he thus gained experience in lecturing and in teaching, developed his research in the embryology of plants, and by so doing equipped himself to succeed Professor William Henry Harvey to the Chair of Botany in the University of Dublin in I866. His stay in Ireland was short for in 1868 he was appointed Professor of Botany in Glasgow in succession to George Arnold Walker-Arnott.

On his arrival in Edinburgh in 1880 he was immediately involved with the problems of the new Arboretum. In the warrant in his favour as Regius Professor of Botany and Regius Keeper of the Garden no reference was made to Inverleith House and the ground 
for the Arboretum. Like his predecessor he was not greatly concerned about Inverleith House, but he was concerned about the management of the Arboretum and its relationship to the Royal Botanic Garden. Consequently he wrote to the Treasury in I880 suggesting that if he was to be responsible for the safe keeping of the Arboretum, it should be placed formally under his control either by an additional royal warrant or by a suitably authorised addition to his present warrant. He correctly pointed out that he could not properly undertake any responsibility in connection with the Arboretum unless he was invested with power to regulate and manage it in such way as, subject of course to higher authority, he might deem most suitable for the purpose. At the same time he suggested that a supplementary grant of at least $£, 500$ should be included in the estimates for the development of the Arboretum. The matter was referred to the Queen's and Lord Treasurer's Remembrancer who recommended to the Treasury that, because the Arboretum could be regarded as an extension of the Botanic Garden in so far as it was devoted to scientific purposes, it was not necessary to issue any new Commission to Dickson, nor to make any addition to the warrant he had already received. However, in so far as the Arboretum was also a place for public recreation under provisions of the Parks Regulations Act, the Queen's and Lord Treasurer's Remembrancer thought that it might be necessary that the Board of Works frame rules to give Dickson such authority as he thought proper. The rules Dickson thought proper for the scientific institution which he conceived the Arboretum to be were those pertaining to the Botanic Garden which was not open to the public on Sundays. On the other hand if the Arboretum was to be placed simply on the same footing as an ordinary park for the recreation of the public there would be no reason why it should not be open every day. Neither would there by any reason for such a recreation ground being placed under the management of the Regius Keeper of the Botanic Garden.

For the time being, therefore, Dickson declined to accept the responsibility of the administration of the Arboretum, firmly believing that it would be exceedingly difficult to manage it if it were opened as a recreation ground to the public on Sundays or at 'untimous hours' (ie, hours out of ordinary working time) either morning or evening; that his first duty was towards the Botanic Garden and that he could not allow anything to intervene which might impair its efficiency or embarrass him in its management; 
that, as the Arboretum and Botanic Garden adjoined each other with intercommunication by existing gates, were the Arboretum. to be managed by him under regulations different from those of the Botanic Garden, he would quite unnecessarily be exposed to attacks from contending parties; that an agitation would be at once organised for the assimilation of the Botanic Garden regulations to those of the Arboretum; and that, as Keeper of the Botanic Garden, he would be compelled to resist such agitation until there were, at least, some reasonable prospect of removal of the serious obstacles to the unrestricted opening of the Botanic Garden, such as the greatly increased expenditure involved, the conscientious scruples on the part of the Garden employees, and, so Dickson thought, the opposition of the greater part of the Scottish population to any interference with the weekly rest day, so much prized by the workmen, either on general or on religious grounds.

The situation remained static until the middle of I88I when the Lord Advocate suggested that the Curator of the Royal Botanic Garden, John Sadler, might take charge of the Arboretum under the Board of Works. Dickson had no objection to this, believing that Sadler might undertake the work without impairing his efficiency as Curator of the Botanic Garden. However, Dickson maintained that, if this arrangement was put into operation, the Arboretum would have to be regarded as wholly outside the Botanic Garden and that, if it was thought desirable to have an entrance from the Arboretum to the Botanic Garden, such an entrance would require a gate-keeper, with shelter box, similar to that at the then entrance to the Garden from Inverleith Row. To meet the necessary expenditure connected with such an entrance gate, Dickson would require to make special application to the Treasury for an additional grant inasmuch as the present one was no more than was absolutely required for the present management of the Garden.

It was not until November I88 I that Dickson finally agreed to Sadler accepting the charge of the Arboretum under Her Majesty's Board of Works, stating 'that it will be my desire to contribute, so far as is consistent with my duty as Regius Keeper of the Botanic Garden, towards the stocking of the proposed Arboretum with plants'.

The stocking of the Arboretum was long overdue, and in November I88I the First Commissioner of Works addressed the Treasury: 
No planting has been done out of the sum of $f_{, 500}$ which has been voted by Parliament .... for the expense of gardening and providing specimens for the Arboretum during the present year. The season for planting evergreens has expired without any steps being taken and it seems more than probable that the period during which deciduous trees can with safety be planted will be allowed to pass by in a similar manner, rendering a re-vote of the grant necessary in the year I882-83. A whole year of the utility of the Arboretum, and of the growth of the plants will thus have been lost. The only works which have been carried out during the present year are those of maintenance and dressing which have been executed by this Department.

Dr Dickson moreover keeps locked the gate which separates the Arboretum from the Botanic Gardens so that visitors to the Arboretum can only gain access to the Gardens by a walk of some three-quarters of a mile; the same obstacle of course prevents visitors to the Gardens from entering the Arboretum except by a similar walk.

Great dissatisfaction is naturally expressed by the public at this unnecessary delay and obstruction; and it is to be feared that unless Dr Dickson be made to refrain from further insisting upon his supposed rights, the Government will be involved in serious difficulties with the Town Council of Edinburgh. Meanwhile the Arboretum in no way fulfils the purpose for which it was bought.

In the same month the Lord Provost, Magistrates and Council of the City of Edinburgh addressed the Commissioners of Her Majesty's Works and Public Buildings, complaining of this same lack of communication between the Arboretum and Botanic Garden.

The upshot of all this was that the Treasury requested the University of Edinburgh to act as mediator between the City Authorities and Dickson. Consequently Sir Alexander Grant, the Principal of the University, Sir Robert Christison, and Dr Hutton Balfour met Dickson and all were agreed that it would not be consistent with the safety of the plants in the Botanic Garden to open a free and unwatched entrance into that Garden from the Arboretum, and indeed that it would be rather absurd to have a careful watch kept at the main gate on the east side (Inverleith Row) to prevent plants and flowers being carried away by that egress, and at the same time to open a back door at the west (Arboretum Road) for the convenience of depredators. They further agreed that all objections to a gate of communication being opened between the Arboretum and the Botanic Garden would be removed if a gate-keeper were provided to supervise the ingress and egress of persons by that gate under the same rules and conditions as those enforced at the east gate of the Botanic Garden. A wooden box or shelter for the gate-keeper would have to be provided by the 
Board of Works and a small annual grant would have to be asked from the Treasury to pay the wages of the person concerned. Finally they were agreed that the gate-keeper should be appointed by and be under the orders of the Regius Keeper of the Botanic Garden and that the gate should be open on such days and on such hours as the Botanic Garden was open to the public.

In January I882 the First Commissioner of Works acquainted the Treasury that he objected to these proposals on the grounds that they provided but imperfectly for free intercommunication between the two properties and that the proposed gate-keeper was unnecessary. On the first matter be pointed out that one gate-keeper would only attend to one open gate but that three gates had been formed at different points along the dividing wall to allow for the freest intercommunication. On the second point he argued that the only public entrance to, or egress from, the Arboretum was by the western gate where there already was a lodge and gate-keeper.

The months passed by without the communicating gate being opened, Dickson maintaining that the plants in the Botanic Garden would not be safe unless an attendant was stationed at any passage from it into the Arboretum, and the First Commissioner of Works refusing to recommend any expenditure of public money for this purpose. Finally the Treasury instructed Dickson, on 22nd June I882, to open one gate for the hours during which the Botanic Garden was open to the public. Dickson accepted his instructionsand placed one of the garden staff in attendance at the gate during the hours the Garden was open. And on 27 th June the SCOTSMAN said: 'Let us be thankful for small mercies'.

The prolonged argument must have been distasteful not only to the sensitive Dickson but to Sadler his Curator, who accepted his office in the Arboretum as from IIth November I88I.

Sadler had been appointed Curator at the Royal Botanic Garden in I879-on the death of James $\mathrm{McNab}$-and the appointment had not won universal approval for it was remarked at the time that he was primarily a botanist by training and not in the gardening tradition of the two McNabs. However he amply justified his two Curatorial appointments, maintaining the Garden in excellent condition and, for the salary of $\mathrm{f}_{2} \mathrm{O}$, carrying out his Arboretum work with great energy. Even before becoming Curator of the Arboretum he planted its protective border with 9,290 trees and shrubs in the month of March I880. And when once his appointment as Curator had gained Dickson's approval he spared himself nothing 
in the Arboretum's development. Although not enjoying good health at the time, he was engaged in planting the Arboretum early in December when a severe snow storm interfered with his work. He caught a chill and died on 9th December I882 at the age of 45 , leaving a widow and seven children. For all his excellent curatorial work he was no doubt happiest in his association with Hutton Balfour and with the members of the Botanical Society, of the Scottish Alpine Botanical Club of which he was an original member, and of the Scottish Arboricultural Society of which he was Secretary for close on 20 years. He had an almost unrivalled knowledge of the plants of Scotland, knowing mosses, fungi, algae, and lichens as well as he knew flowering plants. He discovered many new stations for plants, several of which perpetuate his name, possibly the most notable being the small willow Salix $\mathrm{x}$ sadleri, a hybrid between Salix lanata and $S$. herbacea.

Professor Isaac Bayley Balfour, who knew him intimately, admirably wrote of him:I

John Sadler was a born naturalist. Gifted with talents of a high order, his early life was well adapted for the development of his natural instincts, and the opportunities he had were not thrown away. In his later life he loved to dwell on his rambles when a boy in the neighbourhood of Bridge of Earn (of the flora of which he afterwards published an account) -and the love of nature thus early cultivated remained with him throughout life. As a botanist, Sadler laid claim to be no philosopher. His sphere was not that of abstract morphological or physiological problems-his education did not fit him in that way. But he was a practical botanist; one who knew plants; one who had a marvellously keen, critical, and diagnostic power; and, having an innate love of plants which had led him in quest of them in their native haunts all over Scotland, his experience and knowledge made him at the time of his death one of the first of Scottish botanists. There are few who possessed so extensive a knowledge of Scottish plants, both flowering and flowerless, as he .... His was a knowledge largely bred of experience, and of a kind no amount of book or laboratory work can create; of a kind, too, that cannot be measured by public records; indeed, on looking over the list of his publications, one cannot but feel a shade of disappointment that so much information, the accumulation of a lifetime, should pass away in one individual leaving so slight a record behind, and the loss that Scottish botanists feel at his death will not be lessened the more remote that event becomes....

By his social qualities John Sadler will ever be remembered by those who knew him. Every member of this Society [the Botanical Society of Edinburgh] counted him a friend. Genial and good-natured, with a keen sense of humour, his society was welcome everywhere, and no company could be dull of which

I TRANS. BOT. SOC. EDINB., XVI (I886), p.I4. 
he was one. Who that has climbed an Alpine crag with him will ever forget the numerous accounts of his adventures with which he relieved the difficulties and monotony of the ascent; or who that has enjoyed an evening with him, at say, a meeting of the Scottish Alpine Botanical Club, .... in some Highland inn, will not remember his outflowing spirits and his stories told with all the gusto of real appreciation? To his intimates he was always the same warm-hearted open friend, and his death, unexpected and sudden .... has removed in his prime one who will long be remembered by all of us who knew him as a true friend and genial companion.

Robert Lindsay (Plate Ixb), who succeeded Sadler as Curator both in the Botanic Garden and in the Arboretum, was, like Sadler, an excellent field botanist, being a member, and a very enthusiastic one, of the Botanical Society and of the Scottish Alpine Botanical Club. He possessed an excellent knowledge of alpine and rock garden plants and, when he retired, cultivated them expertly in his garden at Kaimes Lodge, Murrayfield. In his exploration of the Scottish countryside he made several exciting finds, but his most notable was the discovery of the white form of Astragalus alpinus the Alpine Milk-vetch, on Ben Vrackie, near Pitlochry, Perthshire. In I 898 he read a short paper on this white form to the Botanical Society.

However, Lindsay's two main contributions to this Society (apart from his many notes on temperature and vegetation) showed that primarily, unlike Sadler, he was a horticulturist and not a botanist. This is hardly surprising in view of the fact that he entered the Botanic Garden as a boy, worked under James $\mathrm{McNab}$, and passed through all the gardening grades before finally becoming general foreman during the latter part of McNab's Curatorship. On his election to the Presidency of the Botanical Society in I889 he addressed the Society on the genus Nepenthes-the pitcher plants-a group of plants of which he was an expert cultivator, and had been for many years. His first recollection of pitcher plants in the Botanic Garden had been two huge specimens, trained in balloon fashion, of Nepenthes laevis and of N. mirabilis. Unfortunately the plants seldom produced pitchers and it was reckoned a most fortunate thing when Hutton Balfour was able to illustrate his lecture on insectivorous plants, of which Nepenthes is one, by a living pitcher. In Lindsay's time, with improved methods of raising young plants from cuttings and especially with the advent of certain hybrids which freely produced pitchers, pitchers could be had at all times and in great abundance for the lectures of Dickson, and later of Bayley Balfour. At the time of Lindsay's Botanical Society lecture, I 8 species of Nepenthes were in cultivation including the rare 
$N$. bicalcarata of Borneo. The wonderful N. rajah, with the largest pitchers in the genus, had recently died. Lindsay had tried his hand at hybridising these plants and had succeeded in fertilising a female plant of $N$. rafflesiana with pollen from $N$. veitchii. The resulting hybrid, raised in I884, he named in honour of his chief, N. x dicksoniana.

Even more remarkable than his successful cultivation of Nepenthes was the fact that he also grew well that rare pitcher plant from the marshes of King George's Sound, Western Australia, Cephalotus follicularis which carries its leaves in a rosette, the lower ones forming pitchers which capture insects in the same way as do those of Nepenthes.

It is hardly surprising that, with Lindsay growing these insectivorous plants so well, Dickson should make his splendid researches into their minute structure.

Lindsay's second major contribution to the Botanical Society was the lecture he gave, when he demitted the office of President in I89I, on New Zealand shrubby veronicas. The growing of these plants, nearly forty species and varieties of which were in cultivation in the Botanic Garden in I89I, was another of Lindsay's specialities. Of them he raised many hybrids, the best of which is the pinkflowered plant which bears his name, Veronica $\mathrm{x}$ lindsayi, now to be called Hebe $\mathrm{x}$ lindsayi. This resulted from the cross breeding of the white-flowered Veronica or Hebe amplexicaulis and the blue-flowered Veronica or Hebe pimeleoides-both of New Zealand.

Lindsay's horticultural career was thus almost entirely bound up with the Royal Botanic Garden. But it was not a long career, for at the age of 50 , he retired, in I896, the same year in which the Royal Caledonian Horticultural Society awarded him the Neill Prize. He had been Curator for only thirteen years and during the time Dickson refused to accept responsibility for the Arboretum, he had been entirely responsible for its development. Not until I888, when Professor Isaac Bayley Balfour succeeded Dickson, was responsibility for the Arboretum transferred from the Curator to the Regius Keeper of the Botanic Garden.

Though Dickson was Regius Keeper of the Botanic Garden for only seven years, his record of published research exceeds, by far, that of any of his predecessors, for he was first and foremost a research botanist, who, having published his first botanical paper whilst he was yet a student in medicine, never lost his passion for research and published upwards of fifty papers, many of them in 
PLATE IX

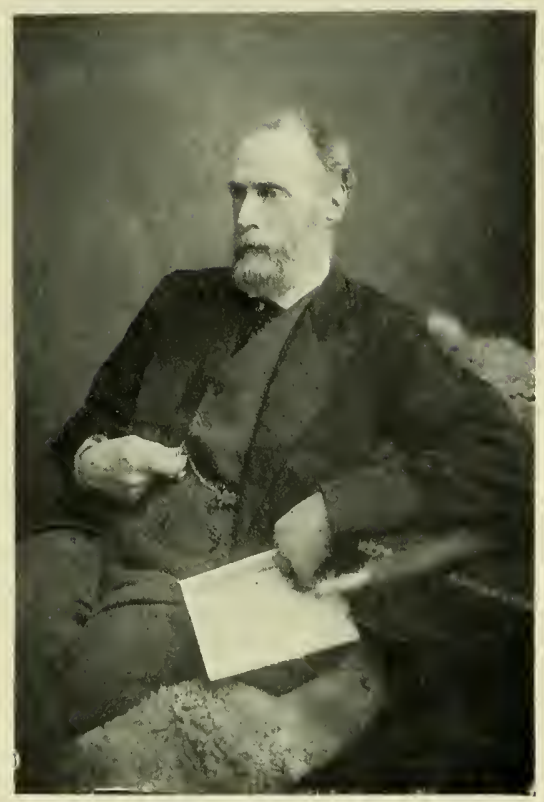

(a) Alexander Dickson (I 836-I 887) Regius Keeper and Queen's Botanist I $880-1887$

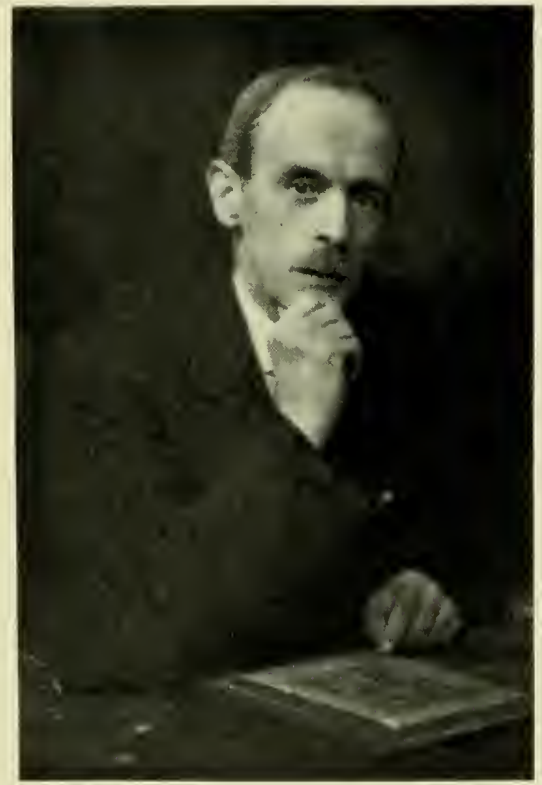

(c) Robert Lewis Harrow (I867-1954) Curator I9O2-I93 I

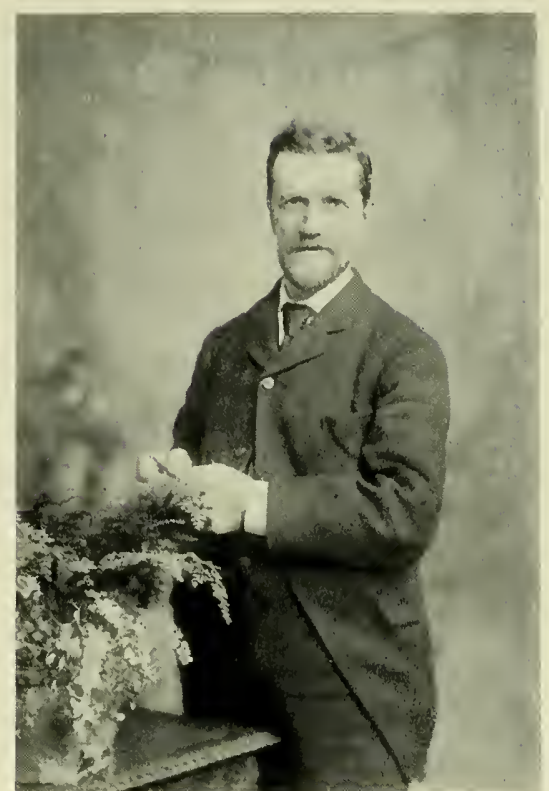

(b) Robert Lindsay ( $1846-\mathrm{I} 9 \mathrm{I} 3$ ) Curator I 883-1 896

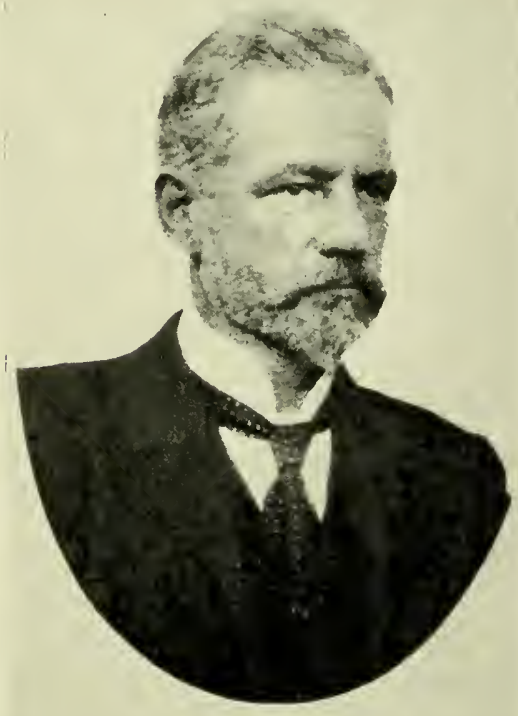

(d) Adam Dewar Richardson (1\$ $57-1930)$ Curator 1896-1902 


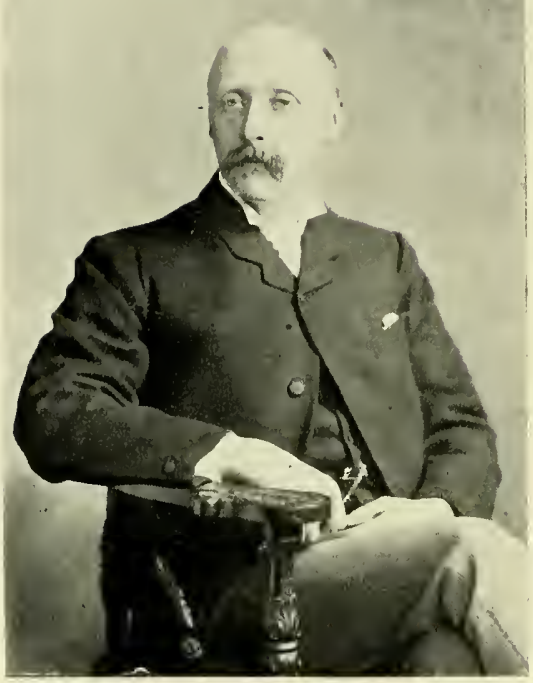

(a) Isaac Bayley Balfour (1853-1922) Regius Keeper and Queen's, later King's, Botanist I 888-1922

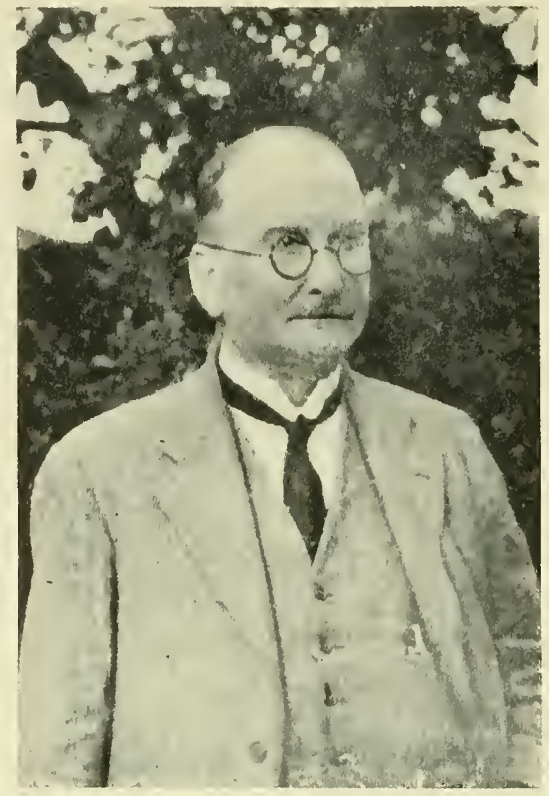

(b) Laurence Baxter Stewart (1877-1934) Curator 1932-1934

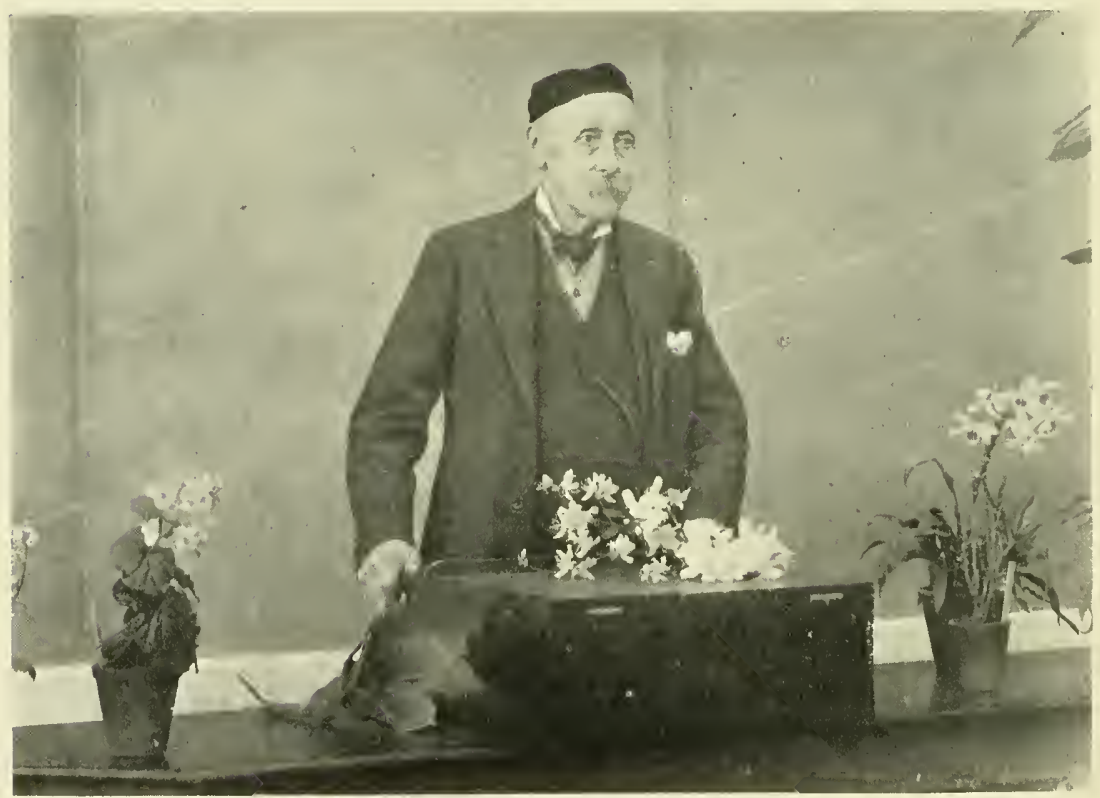

(c) Bayley Balfour at his lecture table 
the TRANSACTIONS of the Botanical Society. For a time he was intrigued by the study of phyllotaxy - the arrangement of the leaves on a shoot expressed by a fraction indicating the distance round the stem separating a leaf from the next above or below, ie, $\mathrm{I} / 4, \mathrm{I} / 3, \mathrm{I} / 2,2 / 5,3 / 8$, and so on. Later, problems of development and morphology occupied him, and in these he made contributions of permanent value and acquired the reputation of an authority. His papers on the morphology of the reproductive organs of the Coniferae, on the embryo and its appendages in Tropaeolum, on the embryology and development of the flower of Pinguicula, and on the morphology and structure of the pitchers in Cephalotus and Nepenthes, all show that Dickson possessed research powers of a high order.

Isaac Bayley Balfour, his contemporary, was to write ${ }^{\mathrm{I}}$ that 'Dickson possessed great skill in manipulation, and was strikingly effective in the use of his pencil in artistic delineation of the objects of his investigation. Careful in his work, he took endless pains to secure that accuracy which it always shows. Further, his subject is always illumined by the comparative method of treatment which his wide knowledge and sound critical faculty enabled him to bear upon it.'

Balfour further wrote: 'Dickson's passion was not teaching, and his success is testimony to the quality of the man. He was adored by his students, as could not be otherwise with a man of his geniality and kindness; he took immense pains over his lectures, spending hours daily over the making of fresh drawings on the blackboard for his classes, holding that a student would copy a temporary sketch although he would not copy a permanent wall diagram; the lecture itself was a model of scientific presentment; at excursions he was untiring in demonstration and in fruitful suggestion, and he was always ready to give of his best to his pupils.'

Undoubtedly the most important development at the Botanic Garden during his tenure of the Regius Keepership was the building of a new and greatly enlarged Lecture Hall which remains indispensable to this day.

On matters outwith his immediate professorial duties and scientific pursuits, another close friend, Professor Thomas R. Fraser, had this to say:2

He was a Conservative in State and Church politics. On various occasions he actively supported candidates for parliamentary presentation. A consistent

I In F. W. Oliver, MAKERS OF BRITISH BOtANy (I9I3), p.zor.

2 TRANS. BOT. SOC. EDINB., XVII, (I889), p.5xr. 
Free Churchman, he remained true to the original position of that Church, and opposed publicly the policy which an influential majority had adopted, of reversing its traditions on the question of a Statc-recognised and -supported Church. He strenuously opposed the legislative attempts, which fortunately proved abortive, to modify the special characters of medical education and graduation in the Scottish Universities, for the mere sake of bringing them into harmony with the systems prevailing in the southern division of the United Kingdom. He looked with much distrust on the schemes, embodied in the various bills introduced into Parliament during the last seven years, for effecting fundamental changes in the constitution and character of the Scottish Universities; considering them prompted more by political, social, and selfish aims, than by a real and disinterested desire for educational reform. If it were possible for one so charitable and generous to entertain any feeling of resentment, that feeling was approached in the indignation with which he regarded many of the statements of the extreme section of agitators for university legislation. Even when he found himself in a hopeless minority .... few men could be more courageous in maintaining or expressing the views he had deliberately adopted.

Polemical discussion, however, was not congenial to his fair and candid disposition. When not engaged in teaching or in the botanical investigations to which he was so ardently attached, his occupations as proprietor of Hartree and Kilbucho, and social intercourse with his friends, were more in accordance with his tastes.

It has been well said that, as a country laird, 'his one aim in life was to make others happy'. And the same characteristic made him also a great favourite in society, where he used to delight his friends by the exquisite taste and feeling with which he played on the piano the works of Beethoven and Bach, and the national airs of Scotland.

His social charms were never more pleasantly exhibited than when he was entertaining his friends at his country house. They werc made to feel as if the place belonged to them, and not to him; except that every now and then the host was recognised by his kindly interpositions to increase the comfort and enjoyment of his guests. His delight was to know that they had been gratified with the day's shooting or curling, or with the ramble over the hills or through the woods, where some matter of botanical interest was invariably brought under notice; their delight was the companionship and conversation of an acute and widely-informed man, genial and destitute of envy, self-denying and careful to avoid wounding susceptibilities, and appreciating heartily what was good in others, because desirous of doing so.

No one could have guessed that beneath this never-ceasing genial and amiable placidity and kindliness, a consciousness existed of a physical ailment, whose course and effect could not with certainty be anticipated for a day, nor even for an hour. It is characteristic of the man that he courageously and considerately concealed all knowledge of the existence of this 'thorn in the flesh', in order to avoid causing anxiety and pain to those nearest and dearest to him. He succeeded in his purpose; and when, on the 3 oth of December 1887 , he suddenly expired on the curling pond at Hartree, no forebodings or anxieties had occurred to increase the bitter grief of his departure. 


\section{A}

\section{CHAPTER SIXTEEN}

\section{Isaac Bayley Balfour}

HUTTON BALFOUR AND ALEXANDER DICKSON HAD NEVER envisaged that the Arboretum should be a thing quite apart from the Botanic Garden. The former had pleaded for the lands of Inverleith not only for an Arboretum but for an extension to the Garden as well, and this was the main reason why the latter had argued to have both the Garden and Arboretum under the personal control of the Regius Kceper. When Dickson died at the end of I 887 the Garden was still far too limited in its dimensions and separated from the Arboretum by a high stone wall. The collections in the Garden were numerous-for the area they occupied, too numerous-with the result that their cultivation left something to be desired; owing to their cramped conditions many trees and shrubs had grown 'leggy' and quite out of character. The planthouses were of old design and so dilapidated as to need renewing. Out-of-date also were the laboratories and, although lecturing accommodation was now adequate, the administrative rooms were quite insufficient. The whole establishment in fact required reorganisation, and in $\mathrm{I} 888$ to this great task came Isaac Bayley (Plate Xa, c), son of John Hutton Balfour, who approached it 'not as a tornado destroying ruthlessly, but as a new climate with storms that remove what is rotten but leave standing what is fit for use.' $I$

Born in 1853 at 27 Inverleith Row, Edinburgh, within a stone's throw of the Botanic Garden, he received his early schooling at Edinburgh Academy. Almost daily he was in the Botanic Garden, in contact with the staff from the Curator downwards, subconsciously, or possibly quite deliberately, receiving a practical training in garden craft which was to be of enormous use to him in

I F. O. Bower, PROC. ROY. SOC. EDINB., XIII (I923), p.234• 
later years. At Edinburgh University he devoted special attention to the natural sciences, more especially to botany. During the summer session in I87I he attended the botany class for the first time and was one of his father's assistants, a duty he undertook every year thereafter until 1878 . When he graduated as BSC in I873 he gained the Baxter Scholarship in Natural Science and was appointed Lecturer in Botany to the Edinburgh Royal Veterinary College, a post he occupied until I878. Along with the 'Baxter' he was awarded a second scholarship on the Vans Dunlop Foundation. This involved his matriculation as a medical student at a time when he was anxious to join the scientific expedition in HMS CHALLENGER, of which his elder brother was the navigator. However, his destiny was not to journey on the CHALLENGER which did not require a botanist, but to be attached, by the Royal Society, as botanist and geologist to the astronomical expedition to Rodriguez in 1874 , to observe the transit of Venus-an assignment which meant the loss of a year in his medical studies. The Rodriguez expedition was a rewarding one for Balfour in that it provided him with the material for a thesis that enabled him to graduate in I875 as DSC in botany with first-class honours-the first student to be awarded the degree of Doctor of Science from the University of Edinburgh.

Balfour renewed his medical studies during the winter session of I875-76 when he became a 'dresser' in the surgical wards of Professor (later Lord) Lister. From 1875-78 he acted as Assistant to the Regius Professor of Natural History in the University, Sir Wyville Thomson, and for two of these years fell under the influence of Thomas Henry Huxley, the great champion of evolution, who was deputising for Wyville Thomson during the time the latter was with the CHALLENGER expedition. The contact with Huxley was to prove a remarkably stimulating one for Balfour. During the summer of 1876 Hutton Balfour was unfit to take his classes and the University Senate, with the concurrence of the University Court, appointed his son to act for half the session as Deputy Professor of Botany. In 1878 he performed the entire duties of the Professorship during the whole session.

In the meantime, during Bayley Balfour's final medical session in $1876-77$, the Chair of Botany in the University of Aberdeen became vacant, and Balfour applied for the post, his candidature being supported by over twenty of Britain's most distinguished botanists, including J. D. Hooker and T. H. Huxley, by a memorial from the students of botany in the University of Edinburgh in 1876 , 
by assistants to the Professors in the Faculty of Medicine at Edinburgh, as well as by graduates and students of the University of Edinburgh. There was only one other serious contender, the Orcadian Dr James Trail, a graduate of Aberdeen, who had had botanical experience in Brazil. The appointment rested with the Crown and Trail's tropical experience won him the day. But Bayley Balfour was so obviously of professorial calibre that it could only be a matter of time before he would be elected to a University Chair. He had to wait for only two years and then, in 1879 , having by now graduated $\mathrm{MB}$, with honours, having studied under Professor de Bary at Strassburg and under Professor Sachs at Würzburg, having monographed the genus Halophila, and having prepared for publication by the Royal Society his report on the botanical results of the Rodriguez expedition, he was elected to the Botany Chair in Glasgow, vacant through the appointment of Alexander Dickson to Edinburgh.

However, before his Glasgow appointment, the Royal Society and the British Association, acting together, had decided to depute Bayley Balfour to study the geology and botany of the Island of Socotra. After completing the work of his first session at Glasgow, Balfour carried out this obligation, spending seven weeks on the island during the winter of $1879-80$, securing valuable data and amassing rich collections, including over 200 endemic species of flowering plants, nearly all of them new, and close on 70 endemic lichens. His Botany of Socotra in the TRANSACtions of THE ROYAL SOCIETY OF EDINBURGH of I 888 is an impressive paper, as indeed are the memoirs on Pandanus, Dracaena and Aloe based on material collected during his visit; they are in part morphological, in part systematic, and in part resolve some economic problems concerning certain well-known drugs. Even at this early stage in his career he was the descriptive botanist his father always had refused to be. And even at this early stage he had the eye for a good horticultural plant, for he introduced to cultivation the free-flowering Begonia socotrana which has played so important a part in the creation of the race of free-flowering begonias which horticulturists now have at their disposal.

At the early age of 35 , Balfour was also a considerable administrator. He was to be in Glasgow only until 1885 , but during this time secured the rebuilding of the main range of planthouses in the Botanic Gardens; established the Kibble house as a Winter Garden; almost achieved the purchase of a house, later to be Queen Margaret 
College, as a botanical institute, and bartered away the only botany lecture room for two rooms suitable as a students' laboratory and, by so doing, created a grievance for himself and his successor which could only be set aright by the provision of new buildings, which, in fact, materialised in I9OI. 'When I succeeded him in I885,' F. O. Bower wrote, 'I found the machinery for teaching in working order, and it only needed to be kept running'.

In 1884, largely through the persuasion of Thiselton Dyer, Balfour was translated to Oxford, to the post of Sherardian Professor of Botany in the University, with the care of the Botanic Garden and the botanical collections. At the same time he was elected to a fellowship at Magdalen and the University conferred on him the degree of MA. He found the ancient Garden-the oldest Botanic Garden in Britain, founded in I62I-badly in need of attention, and the small botanical institute adjoining it in disorder and 'threatened with decay'. Quickly, with the assistance of the garden staff, he rearranged the hardy herbaceous collections and brought the Garden into a far better state, in I 887 making it available to the public on Sundays. Likewise did he reorganise the valuable herbarium and library and made them much better available for study. Most important of all, from the point of view of botany and botanists in general, he established a splendid working relationship with the Clarendon Press.

Balfour's association with T. H. Huxley in Edinburgh and his work on the Continent with Sachs and de Bary had made it clear to him that the advancement of botany in Britain was being hampered by the enormous success of the systematists working in the main with dead plants. The investigation of plants as living things, studied from the points of view of their anatomy and physiologya line of research active on the Continent-was neglected in Britain. The entire approach to botany in Britain needed to be changed, and Balfour and Huxley and W. T. Thiselton Dyer, and F. O. Bower and S. Vines and H. Marshall Ward, and a few others, were determined to bring about a botanical renaissance. In 1875 the Clarendon Press had issued an English edition, prepared by Thiselton Dyer and A. W. Bennett, of Professor Sachs's т EXт в о о K OF BOTANY. More such translations of foreign works were necessary for English workers if the botanical renaissance was to be accomplished, and it was at Balfour's instigation that the Clarendon Press was induced to supply these-under Balfour's general editorship. Equally important for the revival of botany in 
Britain was the foundation of a botanical journal in which new researches could be published. Thus Balfour, gathering around him. a group of young botanists, all interested in the revival, persuaded the Clarendon Press to found the ANnals of BOTANY-a journal now of world-wide repute-and Balfour was the first editor.

On 30 th December I887 Alexander Dickson died, and the vacant Botany Chair was strongly canvassed by Patrick Geddes, who had been Dickson's demonstrator and was also lecturer in zoology in the University. Though unsuccessful in his attempt to fill the Edinburgh Chair, he was appointed Professor of Botany in University College, Dundee, in I889. To succeed Dickson, Balfour was recalled from Oxford to Edinburgh. From this time forth 'the reconstruction of the Edinburgh establishment from top to bottom became the chief aim of his life, and it took him thirty-four years to accomplish it. ${ }^{I}$ He lived henceforth in and for the Garden, and for the University Department centred within it. He was not often seen outside its boundary, a subject of remark sometimes by those at a distance who neither knew nor understood the work or the man.'2

The financial provisions of Dickson's appointment obtained for Balfour. He was appointed by the University Curators, University Professor of Botany in February I888, and Crown Professor and Keeper of the Garden in April I888, with a salary of fir6o. There was no obligation recognised by the Government to give him the Crown appointment although he had been appointed by the Curators to the University Chair. The University Professorship had only $f_{4} 0$ per annum of salary attached to it.

At the time of his appointment, the Botanic Garden was under the dual control of the Treasury and the Commissioner of Works, and Balfour was aware that such control did not make for efficiency. Moreover, the expenditure annually voted by Parliament was not liberal enough to make it possible to maintain the Garden in a manner worthy of a national institution. In addition, a splendid opportunity had been lost by the refusal of the University authorities of an offer made by the Treasury for the maintenance of the Garden as a National Research Institute in Botany in which Edinburgh University students would have a privileged place. Balfour clearly saw that dual control must be abolished, more money must be found for the maintenance and development of the Garden and

${ }^{1}$ His father had also held the reins in Edinburgh for thirty-four years.

2 F. O. Bower, PROC. ROY. SOC. EDINB., XIIII (I923), p.233. 
more opportunities must be made for the furtherance of botanical research.

In I888 the clauses of the Universities (Scotland) Act of I889 were made known and Balfour most strongly objected to the proposal to transfer the Botanic Garden to the University of Edinburgh. He argued the practical difficulty in the transference; the Garden and the adjoining Arboretum received an annual grant of about $f 4,000$ (in the I888-89 Estimates the exact sum was f4,I55); it was proposed to transfer only the Garden to the University-the Arboretum was not mentioned in the Act; if the transference were to be effected, the Arboretum would still have to be maintained by the State, and about a fourth of the present annual grant would be required for it; the result would be that on one side of a dividing wall the Crown would be responsible for the Arboretum, whilst on the other side the University would control the Botanic Garden; such an arrangement would not conduce to economy, and might lead to a certain amount of trouble; it might be urged that all this was no more than an argument for the transfer of the Arboretum to the University, but such a transference would involve a breach of the contract between the Crown, the City of Edinburgh, and the Fettes Trustees made in 1877 when the City purchased the Arboretum grounds.

Secondly, Balfour argued that the transference would be injurious to the Garden itself, and fatal to its continuance and development as a place of enjoyment and as a centre of national scientific education; the maintenance charge would be a heavy one upon the revenue of the University, which, with every desire to maintain the Garden adequately, would find the burden too great for its resources; buildings and plants were all more or less temporary, required constant patching and renewing, and the capital expenditure necessary for rebuilding planthouses could hardly be borne by the University; assuredly the tendency would be to curtail expenditure on those parts provided for the enjoyment of the public, and to limit outlay to what might appear needful for teaching University students; the character of the Garden as a place of public enjoyment would thus inevitably suffer. In its teaching functions, at that time, the Garden did not provide for University students alone; the general public and students from other institutions had access, and made use of it for scientific study; specimens were freely supplied for educational purposes; were the Garden to be placed under the University, this open character 
would be destroyed, for every student would have to matriculate before enjoying the privilege of the use of the Garden for study as it was unlikely that the University would give up its right to a matriculation fee in the case of botany alone of the subjects taught in it. Although, too, the University would certainly be liberal in furnishing specimens to other institutions, economy would limit the number produced and available for such purposes. Clearly the usefulness of the Garden would of necessity be restricted; it would tend to lose its character as an institution open to everyone and to become one limited to matriculated students of the University. Further, there could be no doubt that transference would severely arrest the further development of the Garden; the suggestions for a School of Forestry in Scotland, centred on the Garden, which had recently been urged in public, and the idea of the Garden as a training and teaching ground for young gardeners and foresters, were possible developments under State management, but which, under the jurisdiction of the University, would be difficult, if not impossible, chiefly owing to the want of funds.

Thirdly, Balfour argued that the transference would be injurious to the University itself, which in fact had objected to it and had urged that the responsibility should not be thrust upon it. The Garden had, as has been shown, other duties besides those connected with the University which had no exclusive claim upon it nor any control over its affairs. The relationship of the University to the Garden was that its Professor of Botany had hitherto received from the Crown the Keepership of the Garden, and the University students had thus been able to attend his lectures in the Garden, each one paying a fee to the Curator for the privilege, as did everyone who was not a University student. But if the transference were to be carried out, the University would have responsibilities outside its own proper sphere; besides having to provide for the education of its students, it would also be bound to cater for the enjoyment of the public-a function without precedent; the tax upon its revenue would, however, be so heavy that, notwithstanding the desire it would no doubt feel to maintain adequately the Garden, it would fail in the attempt, and in so doing lay itself open to the reproach of the people for what they would certainly consider a neglect of duty; it would be a serious thing to create such a possible position for a University. Moreover, it would be a reversal of the policy hitherto followed by the State to hand over a National Institution to the control of a body whose sphere of activity was 
limited. In the case of the Natural History collections of the University of Edinburgh, the Government had taken them out of the care of the University and had placed them in the Museum. of Science and Art that they might be better maintained and made more accessible to the public. The proposal to transfer the Botanic Garden to the University, if carried out, would have the opposite effect; it would mean less efficient maintenance, and possible restriction of access.

Furthermore, Balfour argued that the proposed transference appeared open to question on grounds of public policy; hitherto the State had maintained Botanic Gardens at Kew, Edinburgh, and Dublin; now it was proposed to rid the State of the responsibility for Scotland whilst it was retained for England and Ireland; surely such a proposal was not just; surely Scotland was entitled to be treated in the same way as the two sister kingdoms.

Finally, Balfour pointed out that the transference of the Royal Botanic Garden to the University was not an integral part of the Act and could easily be omitted from it. Possibly its inclusion could be traced to the mistaken idea of the connection between the Garden and the University, due to the Establishment Grant for the Garden being voted with the monies for the Universities of Scotland. The vote for the maintenance of the Garden was included in that for Royal Parks and Pleasurc Grounds, and it was with these that the Royal Botanic Garden and the Arboretum in future should be classed, Balfour emphasised, receiving the whole annual grant in one sum, and being subject to the provisions laid down by Act of Parliament for them. Under such conditions it would be possible to remove the wall which now separated the Arboretum from the Botanic Garden, and thus, throwing the two into one, give to the public the great advantage of as free access to the Botanic Garden as they now enjoyed in the Arboretum, and also allow the administration to lay out the whole ground under its care upon one satisfactory plan. Such a fusion obviously could not take place should the Botanic Garden be transferred to the University.

Balfour stated his views in public, and the University, the Town Council, the Trades Council and the public generally all agreed with him. Moreover, he succeeded in convincing the Treasury that the proposal was altogether unwise. As a result, in the Universities (Scotland) Act of 1889 there was a clause which stated:

From and after the first day of April one thousand eight hundred and eightynine all the right, title, and interest of Her Majesty, her heirs and successors, 
in right of her crown as proprietor of the Edinburgh Botanic Garden and all buildings therein, shall be vested in the Commissioners of Her Majesty's Works and Public Buildings for behoof of the public, without prejudice to the rights of Her Majesty, her heirs and successors, as superior of the said garden and buildings, and to the rights of any subject superior in and to the said garden and buildings, the said garden and buildings to be held by the said Commissioners of Her Majesty's Works and Public Buildings upon the conditions subject to which the said garden and buildings were acquired by or on behalf of His late Majesty King George the Fourth.

'Mercies are twice blessed when they come upon us unannounced and unexpected', proclaimed THE SCOT SMAN on 6th April I889:

Of this kind is the arrangement by which the Royal Botanic Garden has been handed over by the Treasury to the charge of the First Commissioner of Works .... To the citizens of Edinburgh it means that at length they will be able to enjoy the full privileges of the beautiful and extensive Botanic Garden .... One result of the change .... is that the Garden will be placed under the same Public Parks Regulations as the Gardens at Kew, and as the adjoining Arboretum. The Botanic Garden and the Arboretum are, in fact, no longer distinguishable, except by the dividing wall .... It necessarily follows that the Garden, like the Arboretum, will be open for the public use and pleasure on Sundays, beginning with tomorrow .... Another benefit, which will become more and more apparent as the summer advances, is that the Garden, like the other Public Parks, will be open all week from dawn to dusk, instead of being closed while there is still a great part of the best time of the day to come; the time, too, when working men and their families are best able to take advantage of the humanising, innocent, and elevating pleasure of strolling through a Botanic Garden.

So popular was the new Sunday opening with the general public that over 27,000 visited the Garden during the four Sundays of April. However, not everyone was pleased. The Free Church Presbytery called the new arrangement 'a most wanton desecration of the Sabbath', and naturally the Sabbath Alliance was as violently opposed as it had been in 1863 . It addressed a communication to the Rt Hon D. R. Plunket, First Commissioner of Works, requesting naively that the Garden should be specially exempted from the regulations applicable to other public parks and grounds under the charge of the Board and thus be closed to the public on Sunday. The only arguments used were those which had won the day in I863. A quarter of a century later they were doomed to failure.

The general public soon had much more for which to be grateful to Balfour, for in order to help intelligent and enquiring men and women to turn their Sunday visits to good account, by giving them knowledge, suggesting ideas and matters for observation, and 
stimulating enquiry, he instituted a series of Saturday evening lectures on elementary botany and horticulture.

So popular with the general public did the Garden and Arboretum become, especially on Sundays, that in the course of their reorganisation and remodelling the walks had to be widened to accommodate the large crowds. In the reshaping of the two properties into one, Balfour was greatly assisted not only by the Curator, Robert Lindsay, but by the general foreman, Adam Dewar Richardson (Plate Ixd). Richardson was born at Garvald, East Lothian, in 1857 , but was taken to Fifeshire when less than a year old and received his early education at the parish school of Largo, where his father had the management of the Largo estate. From Largo the family moved to Midlothian, the father to the charge of the Arniston and Polton estates of Sir Robert Dundas. At this time Arniston was one of the finest properties in Midlothian, its arboricultural features, including some of the earliest planted larches in Scotland, being of great interest. When A. D. Richardson left school his ambition was to train as a mechanical engincer. Lack of facilities compelled him to abandon the idea and he became an apprentice forester. However, practical gardening, and especially landscape gardening, appealed more to him than forestry. At Arniston he gained experience in practical landscape work, for which he further equipped himself by attending a summer course in field engincering at the University of Edinburgh, as well as the University botany class under Hutton Balfour. Richardson then left Arniston and entered the service of a large public works contractor in Edinburgh and gained experience which was to prove invaluable in later years.

When, early in I880, John Sadler invited Richardson to become his general assistant, with special charge of the Arboretum, Richardson was well qualified for the post. He worked under Sadler for two years-until the latter died in I882, and then under Sadler's successor, Robert Lindsay, who for several years had been general foreman. Under the Curatorship of Lindsay, Richardson was promoted general foreman of both the Garden and Arboretum, which by this time were one entity, whilst R. L. Harrow had charge of the Glass Department. When Lindsay retired in I896, Richardson succeeded him as Curator. For some six years he gave Balfour devoted service, his previous training being of great use to him in the relandscaping of the Garden, as well as in the rebuilding of some of the glasshouses. However, apparently the Garden did not offer him enough scope for his landscaping interests, and in 
I902, after a continuous service of twenty-two years, he resigned in order to take up general landscape gardening and advisory work, all of which no doubt was much more financially rewarding than his Curatorship of the Garden.

For the rest of his life he displayed as much interest in forestry as in horticulture, and in the affairs of the Royal Scottish Arboricultural Society of which he had become a member as long ago as I873 when he was an apprentice forester. In 1895 he took part in the first foreign excursion of the Society to North Germany, an experience which gave him an entirely new conception of what commercial forestry really meant, for at that time few foresters in Scotland had seen anything of continental practice and methods. For a time he sub-edited the TRANSACTIONS OF THE ROYAL SCOTTISH ARBORICULTURAL SOCIETY, and edited the TRANSACTIONS OF THE SCOTTISH HORTICULTURAL ASSOCIATION. In 1916 he was awarded the Neill Prize, as a botanist, by the Royal Caledonian Horticultural Society. He died in 1930, in his seventy-third year.

In I890, the Right Hon The Lords Commissioners of HM Treasury considered it desirable that an enquiry should be held "into the position of the Keeper of the Botanic Garden, Edinburgh, and as to the scale on which the outlay on that establishment is to be calculated for the future'. Towards this end a Committee was nominated consisting of $\mathrm{H}$. W. Primrose of the Office of Works; W. T. Thiselton Dyer, the Director of the Royal Botanic Gardens, Kew; Reginald Macleod, the Queen's and Lord Treasurer's Remembrancer and Bayley Balfour. The Committee met in Edinburgh in June and submitted its report in December. It recommended that the association of the University Chair of Botany with the Botanic Garden should be maintained, but that the patronage of the Chair should be transferred to the Crown, in exchange for the patronage of some other Chair connected with medicine. Not until I 896 was this recommendation put into effect, and then it was the patronage of the Chair of Natural History which was transferred from the Crown to the Curators of the University in exchange for the Botany Chair. A further recommendation of the Committee was that the Regius Professorship of Botany should be maintained, that steps should be taken to develop teaching by the Professor to non-University students, and that fees received from such teaching, subject to a capitation grant, should be carried to the Exchequer as an extra receipt. 
The matter of botanical teaching figured prominently in the Committee's report for the reason that it could be the main element in the work at Edinburgh which could not be duplicated at Kew. The Edinburgh Garden was an institution for botanical teaching; it had been founded for this purpose, it had always maintained its tradition and on this account had always occupied a somewhat unique position. But whereas, in the past, the teaching of University students had been the main concern, additionally, in the future, won-academical teaching should be placed on a well-defined basis and an efficient botanical school, affording facilities for research and investigation such as nowhere existed in the country, should be established. If such a school were to be developed, suitable lecture hall, laboratories, apparatus, and supervision would have to be provided. The existing lecture hall and laboratory were without heat and light-and consequently could only be used during the four summer months. Properly equipped, they would be excellent rooms and could be used the whole year round for elementary teaching. But for private work and research there was no accommodation and for this purpose a properly fitted research laboratory, so the Committee recommended, should be added to the present building at a cost of not more than $f^{1}, 000$. A sum of $f_{5}, 50$ should be provided annually in the service votes for the acquisition of apparatus for research and an allowance granted to the Regius Keeper to enable him to provide assistance in the teaching of non-University students.

The Committee next considered the equipment of the Garden. On what scale should a public Botanic Garden of moderate dimensions be maintained? In what directions should its work be directed? A public Botanic Garden should aim at a general representation of the most striking and instructive forms exhibited by the plant kingdom. The representation should be both discriminative and comprehensive. A selection should be made sufficiently to represent wellcharacterised groups, such as orchids, ferns, succulents, etc. Upon such carefully selected series the best available horticultural art should be expended. It was not conducive to the reputation of a scientific institution that the public should receive the impression that plants grown for scientific purposes are less amenable to skilful cultivation than the plants of ordinary gardens. Every Botanic Garden with advantage may specialise in the cultivation of one or more special groups of plants, thereby obtaining for itself a certain distinction which is a stimulus to the staff. 
Applying these principles to the Edinburgh Botanic Garden, the Committee argued that Edinburgh had attained a well-merited reputation for the excellence and interest of its collection of herbaceous plants, grown in the open air, the cool Edinburgh climate being conducive to their culture in many cases much more so than at Kew. In this department, therefore, Edinburgh could very materially supplement the work done at Kew. Because the Edinburgh Garden could not be said to possess any special advantages over Kew, in respect of the cultivation of plants under glass and because the cost of growing plants under glass is necessarily expensive, the Committee gave much attention to this aspect of the work. The Palm Houses, the range of houses 142 yards long and facing south and in great part with lean-to roofs resting on a north wall, as well as the range originally erected by the Royal Caledonian Horticultural Society, were all carefully examined and rather severely criticised.

The large Palm House, opened in 1858 , was unfortunately placed, being too much surrounded by trees which obstructed the light; it was unnecessarily high, the dome at the apex being quite superfluous, even for architectural effect; partly on this account it was impossible to maintain the temperature at a point necessary for the cultivation of the tropical palms and other plants for which it was built. Under these circumstances the contents of the house were not satisfactory. Palms of delicate constitution and requiring really tropical conditions should be being grown, whereas the house was filled with a large number of duplicates of but a few species, hardly any of them requiring really tropical conditions. Thus the Committee recommended that the Palm House should be restored for the purpose for which it was built-the cultivation of tropical plants. The heating should be remodelled; instead of many of the pipes being covered with iron plates so as effectually to cut off the supply of heat, they should be laid under the paths and covered with gratings. In order to check the condensation of moisture in the upper part of the house, a single pipe should be laid along the gallery-a step which had been found effective at Kew. Again, as at Kew, and to remedy the excessive dryness of the atmosphere due to the small surface of soil exposed, the flags which formed the floor of the house should be removed and beds formed in which the palms should be planted out in permanent positions. This would get rid of the enormous tubs in which the palms were then planted, tubs which were costly to 
renew-and rather unsightly. If this were done, other tropical plants could be planted in the beds between the palms to produce a picturesque undergrowth.

The old Palm House of I 834 might be separated from the new one by a glass partition. It would then serve for the cultivation of palms requiring only a cool temperature, and for tree ferns and large temperate plants generally, which, for economy of space, should also be planted out in beds in the ground.

The Long Range presented the Committee with a more difficult problem. When emptied of large plants which would be more properly accommodated in the tropical and temperate Palm Houses, its area doubtless would be susceptible to a considerable curtailment. Unfortunately, because of their comparative large size, the houses composing the range were not well adapted for plants which could only be grown successfully in smaller houses where the atmospheric conditions are more readily under control, and where they are nearer to the glass. Therefore, it appeared to the Committee essential to substitute for portions of the wings of the range, four smaller houses (two with lanterns) of simple and inexpensive modern construction. These should run north and south, and should be adapted for the proper cultivation of plants which were not provided for in a satisfactory fashion-orchids, ferns, economic plants, both cool and tropical, and stove plants. These four houses should be connected with the portions of the old range, which would be preserved, by a corridor which in great measure probably could be formed from materials of the houses to be removed. The existing wall would form its northern side.

The domed conservatory in the centre, with a portion of the range on either side, should be converted into a warm greenhouse (winter temperature $55^{\circ}$ to $60^{\circ} \mathrm{F}$ ). For this, by its lightness and southern exposure, it was well adapted and, when properly organised, should form one of the most attractive features of the Garden.

The eastern and western houses were span-roofed and, though somewhat old-fashioned, were in good preservation. The western one could be devoted to hard-wooded plants, and the eastern one to succulent plants which were more or less unsatisfactorily scattered throughout the range. Eventually the intervening portions of the range might be pulled down.

The heating arrangements required to be completely remodelled. There were no less than twenty boilers in eleven stokeholes-a most wasteful arrangement as regards the cost of maintenance and labour 


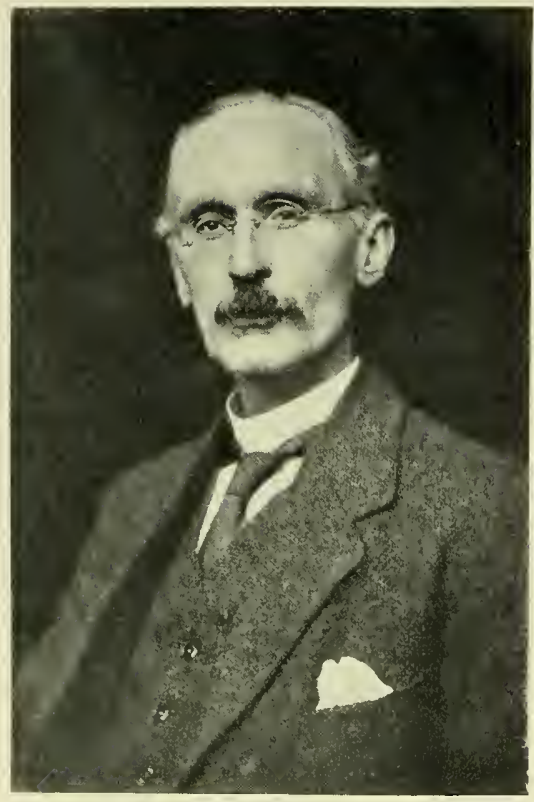

(a) William Wright Smith (1875-1956) Regius Keeper and King's, later Queen's, Botanist I922-I956

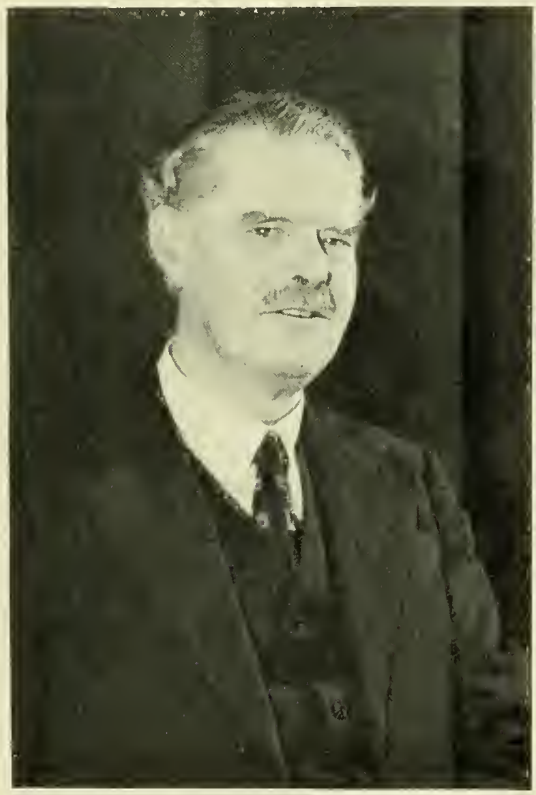

(c) John Macqueen Cowan (I 892-1960) Assistant Regius Keeper 1930-1954

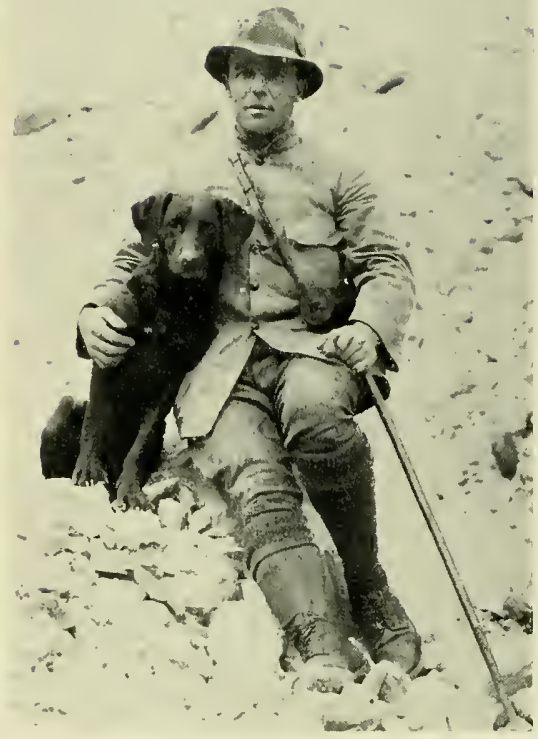

(b) George Forrest (I 873-1932)

Foremost plant collector in the

Himalaya and Western China

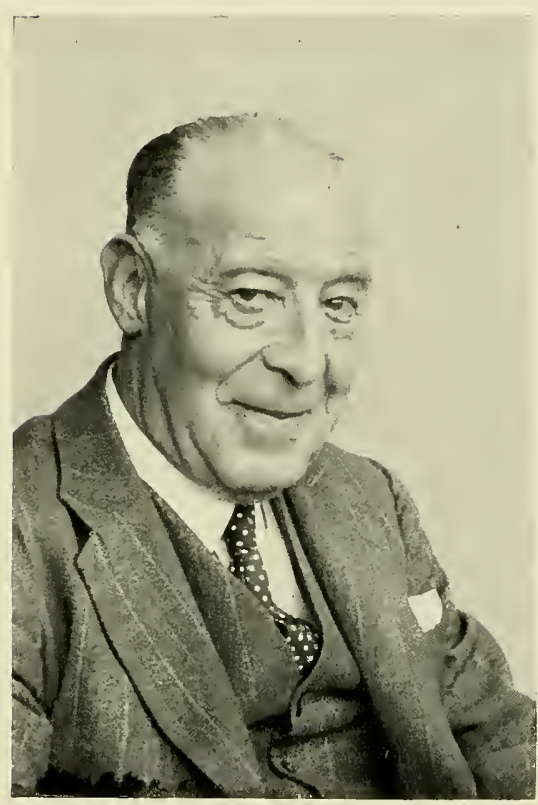

(d) Roland Edgar Cooper (I 89I-1962) Curator 1934-1950 


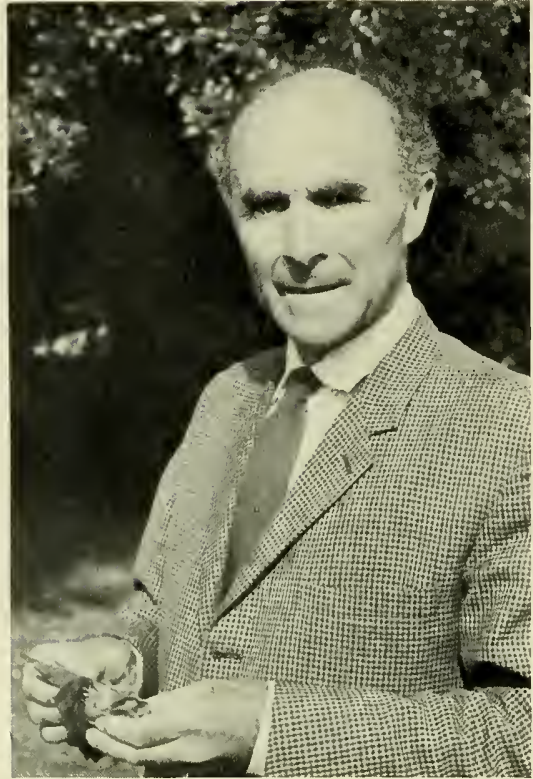

(a) Edward Edmund Kemp (I9ro-) Curator since 1950

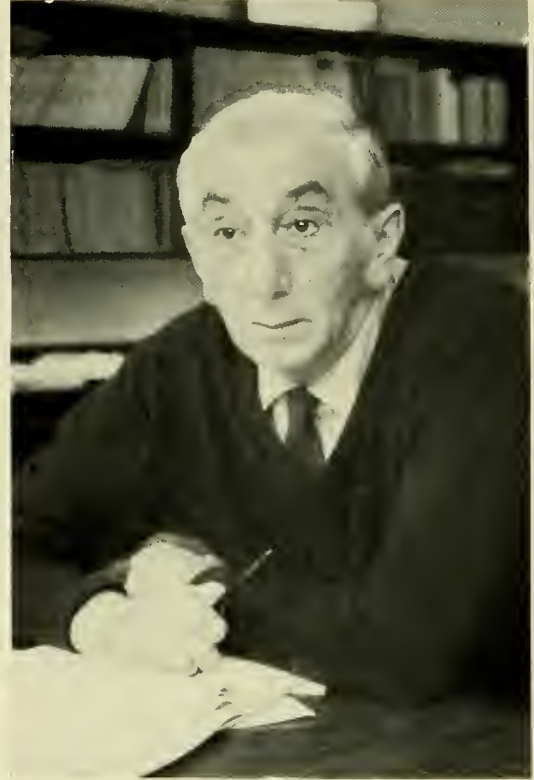

(b) Harold Roy Fletcher (1907-) Regius Keeper since 1956, and Queen's Botanist since 1967

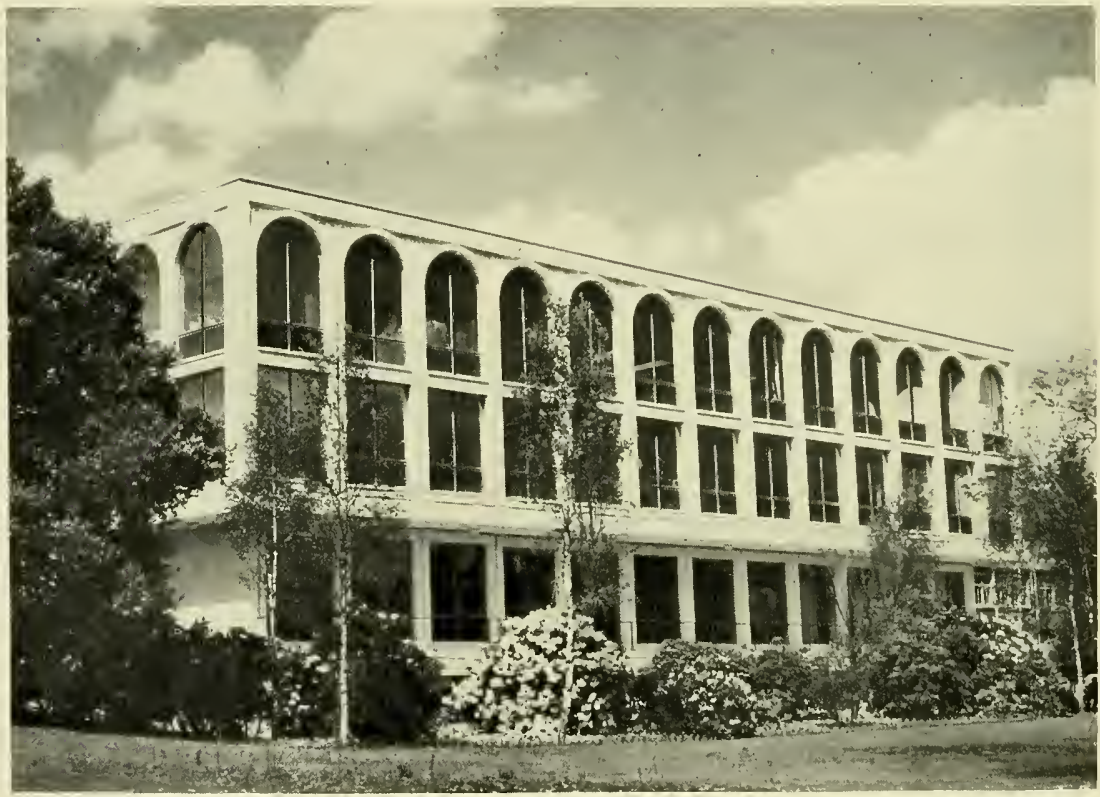

(c) The Herbarium, Library and Laboratory Building. Officially opened by Her Majesty The Queen, 29 June 1964 
and loss of heat. North of the central domed conservatory there was a disused engine-house of substantial construction which the Committee thought might be converted advantageously and at no very great expense into a central boiler-house for the whole of the reconstructed range and for the Palm Houses. Not more than four boilers would be required. The hot water for the range could be carried in one large main which would branch under the corridor, where it would always be accessible, east and west, supplying on its course the houses at right angles by lateral branches.

The range inherited from the Royal Caledonian Horticultural Society presented no problem at all. It was filled with a collection of old camellias planted in the ground, in no degree a necessary adjunct to a scientific establishment. The house was in a very dilapidated condition and was closed to the public. To restore it would cost no less than fir,500. The Committee recommended that the house be abolished and the site utilised for a northward extension of the Rock Garden-one of the most characteristic and interesting features of the whole establishment.

Of tropical aquatic plants there was no representation in the Edinburgh Garden, and the Committee recommended that future provision be made for them. Ultimately a building might be erected, perhaps in the vacant ground south of the Palm House.

After the planthouses had been discussed, there was the question of the Museum. To the Committee a museum appeared to be a proper adjunct of a botanic garden. Of course, the collections in the Botanic Garden themselves subserved in great measure the purpose of a museum. All that was needed to supplement them was a small collection to display, by means of dissections and models, points of structure which could not readily be observed in the living plants as exhibited to the public. The Committee thought the present Museum both instructive and interesting and unlike any other accessible to the public. They recommended that eventually it should be enlarged to occupy about half as much space again; that the models, the private property of the Regius Keeper, be acquired by the Government for a sum of $f_{\text {roo, and that some }}$ assistance in the maintenance and development of the Museum. should be given to the Regius Keeper, at a cost of a further froo. $_{\text {I }}$

The Herbarium, to which a Keeper had recently been appointed, the Committee regarded as an essential part of a national Botanic Garden. It was being given excellent accommodation in the old Exhibition Hall of the Royal Caledonian Horticultural Society, 
where there was room for extension for many years. To gain additional space when the present floor area was fully occupied, all that would be necessary would be the erection of a gallery round the hall. The Herbarium itself consisted of two portions, one belonging to the Crown and one the property of the University which was kept with the Government collections under an agreement of 2Ist November I85I. The two properties were combined in one arrangement, the sheets being stamped in such a way that the University specimens could be distinguished from those of the Crown. The Committee did not regard this arrangement as quite satisfactory, for the University, having the right to remove its specimens, could at any moment break up the integrity of the collection. Even so the Committee made no recommendation for change, but it did suggest that Kew and Edinburgh should establish a system for the exchange of duplicate specimens.

As regards the Regius Keeper's staff, the Committee recommended a few changes. They thought the Curator's emoluments too large.

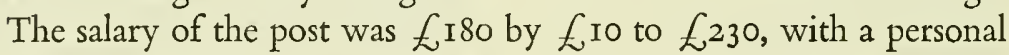
allowance of $f^{20}$ per annum. The Curator also enjoyed a residence rent free, with coal, gas, and water, and a considerable piece of garden which was cultivated for him by the Garden staff. Further, he received a fee of five shillings from each University student attending lectures at the Garden and his emoluments from this source could be reckoned at from $£ 80$ to $\AA^{100}$ per annum. The Committee recommended that, when next a vacancy arose, it should be laid down that these fees should be paid to the Exchequer as an extra receipt and that the salary should be fixed at the rate at which it now stood with the personal allowance included$f^{200}$ by $f^{10}$ to $\AA^{250}$.

The wages of the Foremen, on the other hand, appeared to the Committee insufficient to secure and retain the services of competent men. An emended scale of pay was recommended as follows:

$\left.\begin{array}{lcc}\text { I Foreman } & \begin{array}{c}\text { Present } \\ 40 /- \text { per week } \\ \text { (with a house) }\end{array} & \begin{array}{c}\text { Proposed } \\ 40 /- \text { per week } \\ \text { (with a house) }\end{array} \\ \text { 2 Foremen } & 25 /- \text { per week } \\ \text { I Foreman } & 20 /- \text { per week }\end{array}\right\} \begin{aligned} & \begin{array}{l}\text { at } 28 /- \\ \text { rising to } \\ 35 /-\end{array} \\ & \text { 3 }\end{aligned}$

Two other suggestions the Committee made; the appointment of an additional park keeper during the summer months when the 
Garden was open from $6 \mathrm{am}$ to $9 \mathrm{pm}$, and the expenditure of some $f 800$ on certain minor works necessary to amalgamate more thoroughly the Botanic Garden and the Arboretum.

They summarised their recommendations thus:

To developing non-academical teaching and research

Heating and Lighting Class Rooms

Provision of Research Laboratory

Acquisition of Apparatus

Allowance for Assistant in Laboratory

\begin{tabular}{|c|c|}
\hline Annual Cost & Capital Cost \\
\hline - & $f_{500}$ \\
\hline - & 1,000 \\
\hline Eso & - \\
\hline 100 & - \\
\hline fiso & $f_{\mathrm{N}} \mathrm{I}, 500$ \\
\hline
\end{tabular}

To improving the equipment of the Garden, and the staffing

Annual Cost Capital Cost

Alteration of Houses:

\begin{tabular}{|c|c|c|}
\hline Palm House and the Domed Conservatory & - & $£_{1,100}$ \\
\hline The Long Range & - & 2,100 \\
\hline Remodelling of Heating & - & 2,800 \\
\hline Minor Works & - & $8 c$ \\
\hline Increased Pay to Foremen (approx.) & $£_{70}$ & \\
\hline Additional Park Keeper in Summer & $3^{8}$ & \\
\hline \multicolumn{3}{|l|}{ Museum: } \\
\hline Allowance for Assistance & 100 & \\
\hline \multirow[t]{2}{*}{ Purchase of Models from Regius Keeper } & - & IO \\
\hline & $£^{208}$ & $\AA^{6,900}$ \\
\hline Total & $\{358$ & $f^{8,4}$ \\
\hline
\end{tabular}

On Ioth July I890, Thiselton Dyer wrote to Balfour: 'I have been over my portions of the draft report with Primrose. He agrees and thinks that "it will bowl over the Treasury". I hope it may be so.' Future developments were to prove that it was indeed so.

In the first fourteen years of his Keepership of the Garden, Balfour had had the services of two Curators. He who succeeded Richardson in I902, Robert Lewis Harrow (Plate IXc), was to remain in office for the rest of Balfour's regime-and well into the reign of Balfour's successor. Harrow was a native of Kent, born in I867. After serving his gardening apprenticeship in various private gardens and nurseries in the south he moved to the Botanic Garden in Cambridge and 
there worked under the renowned R. I. Lynch, one of the greatest gardeners of the late nineteenth and early twentieth centuries. Lynch formed a high opinion of Harrow's abilities and in I89I persuaded him to move to Kew where he became sub-foreman of the fern department. In I893 Balfour was redeveloping the Glasshouse Department in Edinburgh and, needing an enterprising gardener to take charge, sought the advice of Sir William Thiselton-Dyer, ${ }^{\mathrm{I}}$ the Director of Kew. Harrow was recommended for the post and thus for the second time a Kew man crossed the border to Edinburgh. William $\mathrm{McNab}$ had moved north in 1810 and served the Edinburgh Garden in incomparable fashion for thirty-eight years. Harrow was also to give thirty-eight years of his life to the Garden, twenty-nine of them as Curator.

Harrow was immediately caught up in the reorganisation of the Palm Houses, but not entirely as Balfour's Committee of I890 had recommended. In the early years of these houses they had been divided by a partition which in the course of time was removed and the two houses maintained at the same temperature. This partition was now restored so that visitors passed from the temperate Palm House with a temperature of $50^{\circ} \mathrm{F}$ into the tropical Palm House with the prevailing heat about $70^{\circ} \mathrm{F}$. For the most part the tubs, in which the palms and other plants in the houses had been grown, were now abolished and the plants placed in specially prepared beds. In the large temperate house the staging round the walls, which cramped and darkened the interior, was removed so as to allow light to enter the windows from top to bottom. On the stone walls, between the windows, wire trellis was fixed for climbing plants. Along the length of the house four large soil beds were prepared, each $33 \mathrm{ft}$ by is $\mathrm{ft}$, two on each side of a six foot wide central passage. Around each bed and along the side of the walls passages five feet wide, formed of gravel laid upon slabs, were formed to allow of close inspection of the plants by the public. The beds were five feet deep with an abundance of rubble below for drainage and with four-and-a-half feet of good soil above. Coils of pipes were placed along the side of the inner wall and along the iron gallery so that in the winter an equable temperature of $50^{\circ} \mathrm{F}$ could be maintained. New Zealand and Australian palms and conifers, tree ferns, myrtles and acacias, and much else, quickly took on a new lease of life.

I The hyphen was assumed about I89I. 
In the tropical Palm House the arrangement of the plants in the ground was much the same. The oldest inhabitant of the house, Sabal umbraculifera, which had been brought from the Garden in Leith Walk, was given a special round bed in the centre of the house. Other conspicuous features of the house were the cycads and their allies. Formerly this house had been heated from a number of small parasitic houses on the outside of the walls. These were now cleared away, the lower walls were opened up and encircling the house on all sides, save that by which the house was joined up to the Temperate House, an iron and glass annexe was built to give about two hundred feet of extra staging. In this annexe many rare and interesting plants were grown, whilst a number of climbers were grown along the ribs of the roof.

At the same time an important rearrangement of the heating appliances in the Garden was undertaken. The numerous furnaces and stokeholes scattered all over the place were now concentrated into one stokehole situated not far from the back of the Palm. Houses. There were four large boilers, with room for a fifth, and the pipes for the heating of the various houses were led from each side of the stokehole or boiler-house in passages four feet high.

The total cost of the reconstruction of the Palm Houses and the new heating arrangements was about $£ 3,000$.

Round about this time Balfour had plans for the construction of a water lily house on the north side of the temperate Palm House, but although the foundations for this house were laid, the project was never completed. Not so his project for the rebuilding of the main glasshouse range, which consisted of heavily built structures of pitch pine, some of the main rafters being 3 in wide, while the width of the glass was in most cases only 7 in. The houses were dark, low-pitched, and with large sliding sash ventilators; each worked independently with a cord and heavy weight. And each house was heated separately. The plants were almost all grown in pots and tubs.

One of the most attractive houses was the Heath House in which fine specimens of Erica and other hard wooded plants were accommodated. Elsewhere Azalea mollis and camellias were largely grown, the former being trained as pyramids and other decorative forms. Chrysanthemums were grown in small quantities but the production of large blooms was discouraged. Orchids were not numerous although, occasionally, a case of newly imported plants was received. These were usually odontoglossums and were 
accommodated in the last remaining old house at the east end of the range. Behind the main range were a few propagating houses, but the main area of ground between the houses and the north wall of the Garden was covered with a dense mass of shrubs.

By I 895 two new houses on the west side of the old range nearest the Palm Houses had been completed. They were each $70 \mathrm{ft}$ long, $24 \mathrm{ft}$ in width and $\mathrm{I} 4 \mathrm{ft}$ high to the ridge of the roof. Running east and west behind them was a corridor which was planned ultimately to extend along the whole range. The part completed in 1895 was $80 \mathrm{ft}$ in length by Io $\mathrm{ft}$ in breadth, with a rubble wall $17 \mathrm{ft}$ in height. Along the corridor was a central path $6 \mathrm{ft}$ in width on each side of which were beds for plants, and on the wall and over the glass roof of the corridor climbing plants were trained. Each of the new houses was divided into two halves. One house was for orchids; those requiring a warm temperature were grown in one half and those needing cooler conditions in the other half. In like manner the other house was reserved for stove plants. Constructed by Mackenzie \& Moncur Ltd in 1895 , these houses were described as being 'of a light and airy character'. Behind the corridor wall was an annexe specially for the culture of filmy ferns, whilst to the north of this was a potting shed and a room for a foreman gardener. Space was retained at the west end of the house for an octagonal fern house.

The two houses and corridor were built at a cost of $f_{\mathrm{I}}, 800$.

By 1898 a new glasshouse range with a frontage of $340 \mathrm{ft}$ had been erected; a centre house with rhododendrons and camellias, myrtles and acacias, and two additional conservatories running from the continuation of the corridor, similar to the others, and for the growing of succulents and economic plants. In I908 a new fern house was opened for tropical ferns, built on the site where William $\mathrm{McNab}$ had cultivated his remarkable Cape Heaths, as well as two other houses, one for temperate ferns and one for heaths. By igis a rhododendron house and two alpine planthouses had been erected and the development of the frame yard had begun. Behind the main range were other houses devoted to the cultivation of insectivorous plants, chiefly pitcher plants-Nepenthes, aroids, and the relatives of the pineapple, the bromeliads.

The range of houses was built on a terrace below which was a collection of herbaceous and woody plants arranged in their families. Balfour remodelled the collection, with the aim of increasing the number of genera to the exclusion of a large number 
of species in which there were only slight differences. Shrubs and small trees were planted mostly to the margins of the collection, whilst some of the less hardy were grown in the shelter of the terrace wall. Lying along the northern boundary of the Garden, Balfour and his Curator, Harrow, about 1903, constructed a southfacing herbaceous border about 200 yards long. Its length was broken up by conifers, hollies and other evergreens and was backed by the boundary belt of deciduous trees, with rhododendrons planted under them. Elsewhere in the Garden (Plan II) an attempt was made to group, as far as possible, the trees and shrubs, according to their families. At this time rhododendrons were becoming more popular, some of the Himalayan species were growing remarkably well, and efforts were made to increase the number of species and hybrids which were grown in beds and borders and interplanted with such herbaceous plants as lilies. Likewise the collection of hollies was increased and these were grown partly for shelter.

Many of the trees and shrubs on the present 'Hill', Balfour himself planted-and was very proud of having done so. On one occasion he was walking round the Garden with Professor F. O. Bower and, with a proud wave of his arm, exclaimed 'I planted all these myself'. 'Splendid', replied the Professor, 'but I see Nectria cinnabarinal on one of them!' 'I know', said Balfour, 'and it is going to be cut out tomorrow morning'.

The Rock Garden, of course, had been famous since the days of James $\mathrm{McNab}$. However, it was not entirely pleasing to Balfour, who from time to time reconstructed part of the rockwork with the aim of abolishing many of the small pockets which had been for so long in use, and of using much larger and more irregular rocks. Even so, in 1907 the Rock Garden was severely condemned by Reginald Farrer in his book MY ROCK GARDEN; he styled it the 'Devil's Lapful'. 'The plan is simplicity itself. You take a hundred or a thousand cart loads of bald, square-faced boulders. You next drop them all about absolutely anyhow; and you then plant things amongst them. The chaotic hideousness of the result is something to be remembered with shudders ever after.' Whether or not Balfour was stung to fury by the taunts of Farrer is not recorded, but possibly it is not without significance that, beginning in 1908, under his personal supervision, the old Rock Garden was torn apart

I The Coral Spot fungus which grows on dead twigs and branches of many trees and shrubs. 
and a new one erected in its place using bold lumps of conglomerate from Perthshire and red sandstone from Dumfries. The work of reconstruction went on each winter until 1914 when the new Rock Garden, which is fundamentally the one of today, was over 3 acres in area. In the middle of the reconstruction, $\mathrm{H}$. Correvon, the great Swiss expert on alpine plants who had built a wonderful rock garden in Geneva, visited Edinburgh, where, so he wrote, 'I saw . . . . alpines which I knew only by reputation. I went there as a pilgrim. to a shrine, and I should never have imagined that such rare and choice plants could be made to flourish together. Words fail me to express my enthusiasm. Everything is flourishing to an extent I never found elsewhere. Professor Balfour is an enthusiast, pur sang, and loves plants in a way I have seldom seen.'

Inevitably all this reorganisation of the Garden required extra labour, and this was in large measure supplied by students in horticulture and forestry-probationers as they were called. Not content with the education of the general public, in I 892 Balfour involved himself in the education of young gardeners and foresters when he organised a course of instruction in the sciences underlying the practice and principles of horticulture and forestry. A curriculum extending from two-and-a-half to thrce years covered such subjects as chemistry, physics, botany, horticulture, forestry, entomology, metcorology, geology, surveying and mensuration, and book-keeping. Lectures and practical work in these subjects were given, free of charge, to the students in the evenings, whilst during the day the students worked in the Garden-and received a weekly wage of twenty-one shillings. In this way were some of the most distinguished horticulturists and foresters of the twentieth century to receive their basic training at Edinburgh.

It was at one of the probationers' classes that one of the most famous of all apples was named. A well-known local horticulturist had been lecturing on fruit and, at the close of his lecture, passed round apples-and asked for criticism. One particular unnamed apple appealed to the probationers, who suggested that it be named after the lecturer. Thus was the apple 'James Grieve' given its name.

Those employed in the Garden worked long hours-from 6 a m until $5.30 \mathrm{pm}$, and from $7 \mathrm{am}$ until sunset during the winter months. The week's work did not end until Saturday evening. Holidays were very short and for a time a choice of Christmas Day and Boxing Day, or New Year's Day and the following day were allowed, together with Good Friday. New members of the 


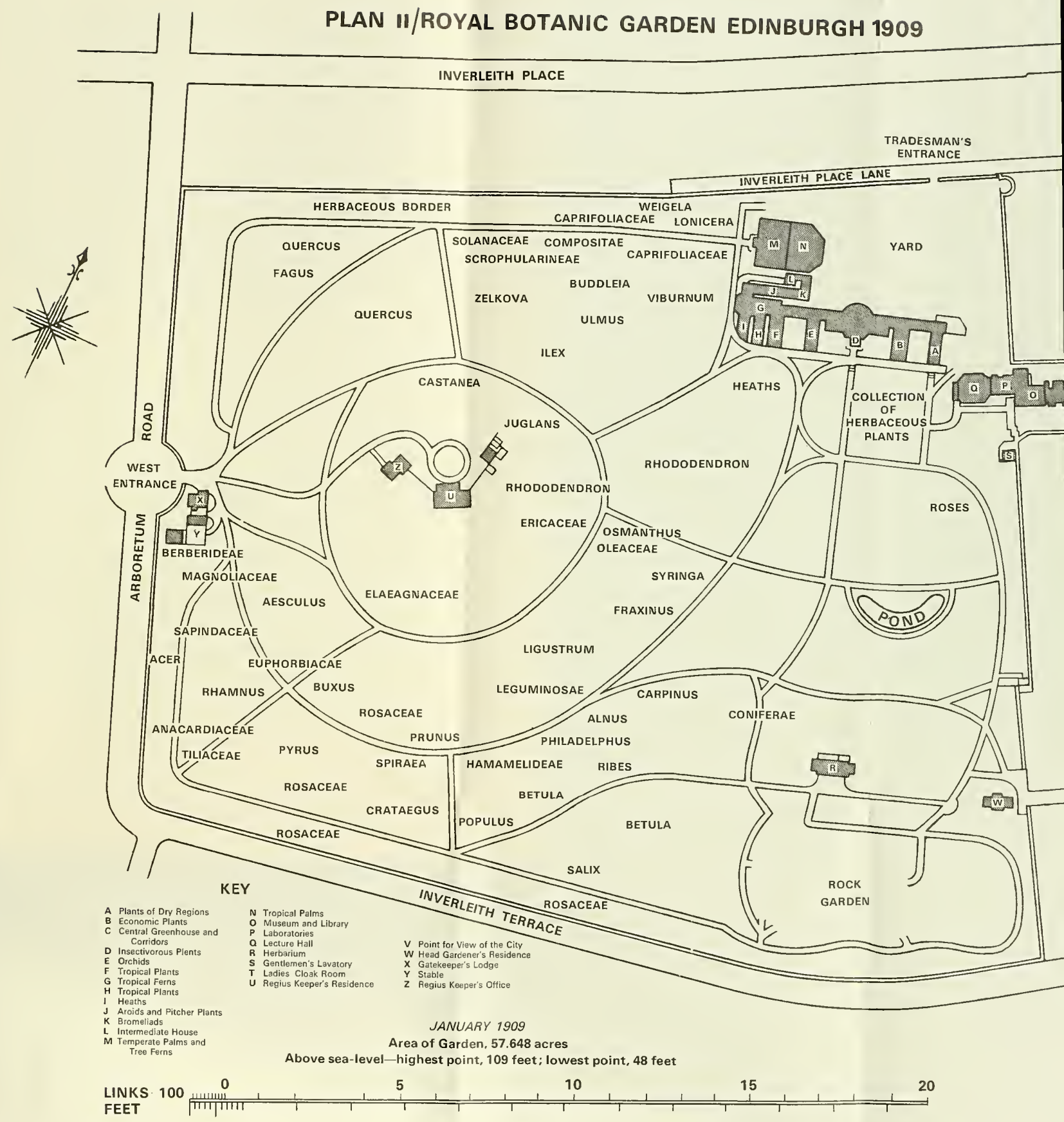



gardening staff were always disgusted when they heard that leave for holidays would not be granted until after a period of one year's service.

Long hours though they may have worked, the morale of the staff was always high, and in I9I3 they formed themselves into a Guild. The driving force behind this was Walter Morland, who had joined the staff as a gardener in I9I0, especially to take charge of the herbaceous collections. He first made the suggestion for the formation of a Guild and the publication of a Guild JOURNAL, in I9I2, with the object of promoting social intercourse between past and present members of the staff. Not until the following year was the Guild inaugurated and then Bayley Balfour was elected the first President and Morland the first Secretary. The I9I4-I8 War, during which Morland and nineteen other members of staff lost their lives, put a temporary halt to the Guild's development. After the war, however, the Edinburgh Royal Botanic Garden Guild successfully began to fulfil its function and, with a membership which is scattered throughout the world, today admirably serves to link together past and present members of staff. 


\section{CHAPTER SEVENTEEN}

\section{Bayley Balfour and the Sino-Himalaya}

BAYLEY BALFOUR, THISELTON DYER, VINES, MARSHALL WARD and Bower, through their championing of the New Botany of the Continent, did much to change the face of botany in Britain: they shifted the emphasis from the study of the dead plant to the living; from the herbarium to the laboratory and garden; from external morphology to structure, function, development, and life history of both flowering and non-flowering plants. Thus, when Bayley Balfour returned to Edinburgh in 1888 , the times were wonderfully stimulating. The times were also impossibly exacting, for now the whole wide field of botany was covered by the Professor, working practically single-handed and without teaching assistance. However, the following year the New Ordinances under the Universities (Scotland) Act were to change all this. Degrees in science were established, advanced courses of instruction had to be given and, consequently, greater accommodation and staff for teaching and research had to be found. In addition to reorganising the Botanic Garden and re-equipping it with new glasshouses and other ancillary services, Balfour had therefore to build up a new University Department of Botany. The great task occupied his attention for over thirty years. Gradually the Botany Buildingthe building which is now $20 \mathrm{~A}$ Inverlcith Row-took on its present form, the last addition being made in 1920 when a large laboratory for elementary teaching was completed.

Between roro and ror2 the erection of the Botany Building was the subject of much controversy between Edinburgh Corporation and the Commissioners of Works and Public Buildings. Until rgro 
the public entrance to the Botanic Garden from Inverleith Row was in the space between the houses Nos. 20 and 2I. In I9IO the Commissioners closed this entrance and erected, on the entrance space, buildings for laboratory purposes. The public entrance to the Garden was transferred to the lane between Nos. 7 and 8 Inverleith Row. The laboratory buildings extended for $82 \mathrm{ft}$ along Inverleith Row on a line $26 \frac{1}{2} \mathrm{ft}$ from the centre of the street; the adjoining buildings were on a line $44 \frac{1}{2} \mathrm{ft}$ from the centre and thus those of the laboratory interfered with the symmetry of the handsome line of frontage of Inverleith Row. The buildings, and their erection, excited considerable public opposition as impairing the beauty of one of the leading accesses to the City and as threatening a real injury to the amenity of the street inasmuch as they interposed a serious obstacle to any scheme for widening the thoroughfare at some future date. Notwithstanding the expressions of public disapproval, the Crown authorities persisted in their proposed course. However the Commissioners did present an application to the Dean of Guild Court for a lining, which technically, apparently, they were not bound to do. Certain objections seem to have been taken by the Corporation which were adjusted, but no serious attempt was made to rectify the building line by having it set further back from the centre line of the street. The application went through the Dean of Guild Court, the application was proceeded with, and the building was completed.

Prior to the inception of this building scheme, the Edinburgh Corporation Act of 1906 had made provision enabling the Corporation to require that no houses or buildings should be erected within thirty feet of the centre line of the street. At the date of the proceedings in I9Io no steps had been taken to render this provision operative in regard to Inverleith Row, but on 2oth September I9I I the Corporation passed an Act of Council resolving 'that no houses or buildings shall be erected in Inverleith Row within a distance of thirty feet from the centre line' of portions of the street, including that opposite the Laboratory Buildings in the Botanic Garden. This somewhat belated resolution was prompted by a proposal of the Commissioners of Works to extend the buildings already erected along the remaining northern part of their frontage, and also to erect a porch. For this extension, warrant had been applied in the Dean of Guild Court on 2nd September I9II. The proceedings of the Dean of Guild Court led to no definite result-except that the porch proposal was withdrawn. However in October I9II the 
Corporation raised an action in the Court of Session to have the Commissioners restrained from proceeding with the buildings and forced to keep to the thirty foot line as far as the proposed extension was concerned. The Lords Ordinary decided in favour of the Corporation, but, on appeal, the First Division reversed this and found that, upon the construction of a particular clause in the Corporation Act of 1906, the resolution was not in this case binding upon the Department.

Understandably the whole unfortunate business caused a certain amount of resentment in Edinburgh, the more so as, in the past, the Corporation had acted liberally towards the Commissioners of Works. The Corporation had paid $f_{18,408}$ for the Arboretum and had handed it over to the Department. Again, when the strip of land to the south of the Arboretum had been in danger of being applied to a purpose which would have been detrimental to the Botanic Garden, the Corporation, on the urgent entreaty of Bayley Balfour, had acquired the ground at a cost of $\oint_{\mathrm{N}} \mathrm{I0,000}$ and had secured that it should be laid out in such a way as was best and most advantageous to the Garden.

In the end a compromise was reached. The Town Council proposed that, if the Commissioners of Works would agree to the building line being set back some 9 or Io $\mathrm{ft}$ from the centre of the roadway, the Corporation would go to the expense of taking down the front of that part of the building already erected and rebuild it on the new line, using not brick but stone. The Commissioners pointed out that, owing to the loss of space caused by the setting back of the building, it would be necessary to provide equivalent accommodation behind the building, and would only agree to the Corporation's suggestion provided that the latter was willing to pay for the cost of such accommodation. Thus the compromise involved the expenditure of some $\mathcal{E}^{2,000}$ by the Corporation.

At appropriate moments Balfour gradually increased his staff. As early as I894 he made Government appointments in the Herbarium. and Museum. To the charge of the Museum, Harry Frank Tagg was appointed. Tagg was but twenty years of age when he joined Balfour's staff, having received some training in horticulture at Swanley College in Kent. Thereafter for nearly forty years he was to fill the post of Assistant in the Museum. In this capacity, in I904, Balfour granted him long leave of absence for the purpose of collecting botanical material, for his Museum, in other parts of the world, and in the course of this prolonged tour he visited Australia 
and New Zealand. His early years in Edinburgh were devoted to the study of plant pathology, especially with regard to the diseases of timber, and during the I9I4-I8 War he performed valuable work as Scientific Officer to the Timber Supply Department under the Board of Trade. In the preparation of museum exhibits Tagg was an expert, developing methods for the preservation of specimens which were quite unique at the time. Gradually, scope for his activities in the Museum became less and less. At the same time scope for research in taxonomic botany in Edinburgh increased enormously with the influx of the rich collections from the SinoHimalaya. Thus, under Balfour's prompting, Tagg turned his attention to taxonomy and especially the taxonomy of the genus Rhododendron on which he became a great authority.

To the charge of the Herbarium, John Frederick Jeffrey was appointed. He came to Edinburgh from Kew and was to be one of the furst privileged to handle the herbarium collections from the Himalayas and Western China which began to pour into the Herbarium from 1904 onwards. He worked among the herbarium collections until the end of I9I7, when, due to failing eyesight, he retired to Somerset where he lived until his death in I943.

Jeffrey was succeeded in the Herbarium by William Edgar Evans, whose grandfather for a time had been Curator of the Royal Caledonian Horticultural Society's Garden, before it was incorporated into the Botanic Garden, and whose father, William Evans, the foremost Scottish naturalist of his day, had been born in the house in the Garden occupied by Curators of the Horticultural Society and later of the Botanic Garden. W. E. Evans had been educated in Edinburgh, first at Merchiston Castle School and later at the University, graduating BSC in 1906. After spending two years as a Carnegic Scholar in Botany, at the Botanic Garden, he had been appointed Assistant in Mycology to Professor Emil Westergaard, at the Heriot-Watt College. From I9I6-I9 he was in the army and, on his returning to Britain in I919, Balfour appointed him Assistant in charge of the Herbarium and in this capacity he worked until his retirement in 1944, naming the vast collections from the Sino-Himalaya and specialising in certain groups such as Nomocharis, Coluria, Diapensia and Vaccinium, on which he published revisions or notes in the NOTES FROM THE ROYAL BOTANIC GARDEN EDINBURGH.

To the Herbarium staff, and to a very menial post, one other was appointed, in 1902-George Forrest. Born at Falkirk in 1873 , 
and educated at Kilmarnock Academy in Ayrshire, Forrest, on leaving school, had found a post in the shop of a plarmaceutical clicmist. Though this was little to lis liking it did give him an interest in botany through which he acquired a knowledge of the native flora. But life as a potential chemist was too inhibiting for him and he departed for Australia to scek what fortune he could. For several years he enjoyed the open air life of the 'bush', but, furding little prospect of advancement, he returned home in s902and accepted the poor post in the Edinburgh Herbarium. Indoor work on dried plants must have been an enormous change from his life in the Australian bush, but he took his excrcise by daily walking the six miles from his home to Edinburgh, and back, and by standing at his task in the Herbarim, where for two years he was able to scrutinise the thousands of specimens from all parts of the world and to gain a sound knowledge of the main families and genera of plants. At this time neither he, Balfour, nor anyone else, was to realise that soon he was to give direction to the future line of botanical research to be pursued in Edinburgh.

Not until 1912 did Balfour make an appointment in the Library, which by that time was of considerable proportions. Then James Todd Johnstone was placed in clarge. Jolnstone, who always maintained that he was descended from Robinson Crusoc, was the son of an antiquarian bookseller from Dumfriesshire. By assisting his father in the bookshop in Dundonald Strect, he gained a good knowledge of books, bookbinding and printing; as he had studied botany in his University degree (he specialised in mathematics), he was thus a splendid choice for the Library post which he filled for thirty-five years. For many years he also acted as Assistant Secretary to the Botanical Socicty and edited its TrAnSACtions. And for many years be also cdited the NOTES FROM THE ROYAL BOTANIC (:ARDI:N EDINBURCil which Balfour established in 1900 as the official scientific publication of the Carden.

The other post created at this time was that in the Laboratory. At first this was temporarily filled by Bertha Chandler and then, in 1913, Mattliew Young Orr was appointed. He came to Bayley Balfour as Assistant in the Laboratory, from Cardiff University, and on the staff of the Garden he was to serve for thirty-four years. Although, as many of his published papers show, he was interested in plant amatomy and plant abnomalitics, like other botanists on Balfour's Government staff he was greatly to be influenced by the new Sino-Himalayan introductions. It was on 
the conifers that he specialised and on which he becane a leading authority, being consulted from far and wide on problems of their identification by foresters, garden owners and others. Apart from being a rescarch worker, Orr was also a lucid teacher who over the years lectured to University students as well as to the botany class of the Edinburgh Workers' Educational Association.

In 1903, Balfour appointed to an assistant head gardener's post, under Curator Harrow, Robert Moyes Adam, who soon proved that he was much more than a gardener. He had a flair for drawing and a deep interest in the native plants of Scotland. His talents were quickly spotted by Balfour, who used him in the Laboratory for the preparation of diagrams to illustrate lectures. A talent he was to develop above all others was that for photograpley; in his spare time he photographed the native plants be loved so much, especially the alpine plants, as wcll as their habitats; and in his official working hours he photographed vast numbers of the new Sino-Himalayan introductions which were growing in the Botanic Garden. Balfour promoted him to the post of Photographer and Artist, and in 1915 created for him a new post, that of Assistant in the Studio. This post Adam held until he retired in 1949, by which time he had won for himself an unrivalled reputation as a plotographer of the native scene and of native plants.

At the same time that Balfour was building up his Governmental staff he was also assembling together a group of colleagues to assist him in the University teaching. The first appointment he made was that of 1894 when William Gardner Smith filled the post of Assistant and Lecturer in Plant Physiology, after graduating in science at University College, Dundec, in I890, after having done post-graduate work in botany under Balfour, and having continued his studics at the University of Munich. Though Smith held the post only until 1898 he amply justificd Balfour's sclection for in later ycars he proved to be one of Britain's pionecr plant ccologists and it was largely due to his efforts that the British Ecological Socicty was founded.

In 1899 the post of Lecturer and Assistant in Plant Physiology was filled by Albert William Borthwick who had received his carly education at Madras College, St Andrews, and at the University there, where he graduated in scicnce in 1895 , proceeding to the degrec of DSC in 1904. For threc years he was in Munich making a special study of forestry and forest pathology before joining Baylcy Balfour in 1899 . In 1908 he ccased to be Lecturer in Plant Physiology 
being transferred to the newly instituted Lectureship in Forest Botany which post he retained until I9I4. With the outbreak of war he severed his connection with the Edinburgh University Department of Botany. He became Chief Advisory Officer in Forestry to the Board of Agriculture for Scotland. A natural sequel was his translation to London as Chief Research and Advisory Officer to the Forestry Commission which was established in I9I9. And in 1926, when the Chair of Forestry was instituted in the University of Aberdeen, Borthwick was elected as its first occupant.

Borthwick was succeeded in the post of Assistant and Lecturer in Plant Physiology, in 1908, by John William Bews, an Edinburgh graduate who for a year had been Lecturer in Economic Botany in the University of Manchester. He was to stay with Balfour only until I9Io when he left for South Africa where he served botany with great distinction for the rest of his professional life. In like fashion, Bews's successor in Edinburgh was to serve Balfour only until 1912. William Brown was a Dumfriesshire man who, like Bews, had also graduated in Edinburgh. Leaving Balfour's service he moved to London, to the Imperial College of Science and Technology, where, first as Assistant Professor, and then as Professor and Head of the Department of Botany, he had a most distinguished career as a plant pathologist.

Balfour replaced Borthwick in the post of Lecturer in Forest Botany in I9I5-and in Indian Forest Trees in 1917-by William Grant Craib, a native of Banff who was educated at Banff and Fordyce Academies and at the University of Aberdeen where he graduated $\mathrm{MA}$ in 1907. The following year he received a temporary appointment as Acting Curator of the Herbarium at the Royal Botanic Garden, Calcutta, and while in India made large collections of plants from the North Cachar Hills. In Igog he accepted the post of Assistant for India at Kew, where he became deeply interested in the flora of Siam. His association with Balfour in Edinburgh lasted only for five years, for in 1920 , in succession to Trail, he was appointed to the Regius Professorship of Botany at Aberdeen where he worked unsparingly on the flora of Siam until his death in 1933 .

Two more of Balfour's Lecturers gave him, and the University Department of Botany, longer service. In I9I I Balfour was anxious to fill a Lectureship in Mycology, and after consulting Sir John Farmer of Imperial College, London, appointed Malcolm Wilson, who was to spend the rest of his professional life in Edinburgh, 
retiring from his post of Reader in Mycology in I95I. Wilson had been a student at Swanley Horticultural College before taking first-class honours in botany in the Bachelor of Science degree of London University. In Edinburgh he proved himself a most stimulating teacher, all his students being impressed not only by his enormous mycological knowledge but also by his firm grasp of much of the botanical field. Teaching apart, he brought considerable renown to the mycological department in Edinburgh by his researches, especially those on the rust fungi. A major work on these was to be published by the Botanical Society in 1934 and a further one, in the TRANSACTIONS OF THE BRITISH MYCOLOGICAL SOCIETY, twenty years later. At the time of his death, in I960, he was engaged on a revision of the rust fungi of Great Britain. Fortunately, one of his former students, D. M. Henderson, was to take up the task Wilson left and to publish the revision in 1966 , as a joint work.

The other Lecturer, appointed by Balfour, who was to devote the major part of his professional life to the University Department of Botany, was James Lindsay Salmond Smith. Appointed in I9Is to teach plant physiology, in 1920, in succession to Craib, he took over the teaching of forest botany and of Indian forest trees and still later, in 1934, was appointed Lecturer in Botany. Thus from I9IS until he retired in I950, he devoted himself entirely to the teaching of the thousands of students who attended the University Botany Department during this period. Strangely, he had no taste for research and there is no record of his having published a single research paper.

Above all else Balfour expected his University staff to be good teachers and, though he himself was to undertake a vast amount of research, in the Department as a whole more emphasis was placed on teaching than on research. Certainly it is true that during his regime Edinburgh became the chief centre in Britain for the teaching of the classification of the flowering plants.

What was to prove to be Balfour's most important appointment was made in I902, when he invited William Wright Smith to become onc of the Assistants and Lecturers in his University Department. Smith was born in Dumfriesshire in 1875 and had been educated in Dumfries Academy before entering the University of Edinburgh. Whilst pursuing the course for a Degree in Arts at the University he completed the Diploma Course at Moray House Training College, intending to become a teacher. And on com- 
pletion of the Arts Curriculum in 1896 he did, in fact, take up a teaching appointment under the Edinburgh School Board. But at the same time he was able to pursue scientific studies, devoting his time chiefly to botany, chemistry and zoology. He accepted Balfour's invitation and from 1902 until 1907 assisted him in the conduct of the large practical classes for medical and science students, in the teaching of advanced botany, and in the superintendence of research work.

In 1907 the opportunity came for obtaining overseas experience. Supported by Balfour and by Lt Col David Prain (later Sir David), the then Director of Kew, Smith was appointed to the charge of the Government Herbarium in the Royal Botanic Garden, Calcutta. He spent four years in India, gaining experience in the administration of a large scientific garden. Moreover, in 1908 he officiated as Director of the Botanical Survey of India and by so doing gaincd, at first hand, a wide acquaintance with the flora of India and Burma. In I9I I Balfour invited him to return to Edinburgh, not to the University staff again, but to the staff of the Garden, in the post of Deputy to the Regius Kceper under HM Office of Works. This post Smith was to hold until I922, when, on Balfour's retirement, he succeeded to the dual post of Regius Keeper of the Garden and Regius Professor of Botany in the University.

The nature of the main scientific work of the Garden was determined in 1904 when a Liverpool cotton-broker, Arthur Kilpin Bulley, the first of the great twentieth-century patrons of plant-collecting, appealed to Balfour for advice. Gardening was Bulley's hobby, and his garden at Mickwell Brow, Ness, Neston, Cheshire, had become celebrated. Part of his garden he had used as a conmercial nursery and to such profit that he had founded the nurseryman and seedsman's firm of Bees Ltd. Interested in the introduction of forcign plants, he now asked Balfour to recommend a man adequately qualified to travel and collect personally for him in Western China. Balfour recommended George Forrest (Plate xtb), who left for China in 1904.

Undoubtedly at this time Balfour was aware of the richness of the flora of the provinces of Western China. Augustine Henry, after qualifying in medicine at Edinburgh, in I88I, had accepted a post with the Chinese Maritime Customs, and had collected in the region of Ichang, by the gorges of the Yangtze River, and had sent off a box of specimens to Kew in I886. By the time he retired in I900, Henry had sent some I58,000 dried specimens to Kew. The 
French missionaries David, Soulié, Farges and Delavay, had likewise collected many thousands of dried specimens from the provinces of Yunnan and Szechuan and had sent them to the Paris Herbarium. Balfour was aware of these dried collections in Kew and Paris and saw in the departure of Forrest in 1904 the opportunity for the introduction of living plants into British gardens, the opportunity to augment the collections of seeds, bulbs and living roots which Ernest Henry Wilson had recently introduced on behalf of Messrs Veitch, who in 1899 had sent him to China with the main objective of introducing Davidia-the Dove or Handkerchief Tree.

Forrest returned home in 1907 and the expedition had been successful beyond all expectation. He brought home with him thousands of herbarium specimens and many pounds of seeds as well-and the knowledge that, somehow or other, he had to return to China. And return to China he did, on six other occasions, so methodically organising his work there, so skilfully training his native collectors, that he was able to introduce plants on a far larger scale than ever before. In his later expeditions he received much financial support from the Rhododendron Society, which was formed in I9IS, and in particular from John Charles Williams of Caerhays Castle, Cornwall. Williams had begun growing rhododendrons about I885 and was one of the early successful hybridisers of these plants. One of the leading figures in the Rhododendron Society he encouraged Forrest to collect all the rhododendrons he saw with the result that by 1917 he had in cultivation in Connwall over 250 of Forrest's rhododendron introductions.

When Forrest died in Western China in 1932, on his last expedition, he had collected over 30,000 magnificent herbarium specimens and had introduced hundreds of new plants into cultivation. All the herbarium material had been deposited in the Edinburgh Herbarium and most of Forrest's seed collections had been cleaned in Edinburgh and distributed from the Garden to those who had subscribed to the expeditions, to other private growers and other botanical institutions. Examining the herbarium. collections of the first expedition and studying carefully the raising, in the Botanic Garden, of the plants from Forrest's seeds, Balfour realised immediately that the new material, if it could but be grown, and when once it was named, would completely change the face of gardening and gardens in Britain: Aucuba, Ligustrum, holly and yew would give place to Rhododendron, Camellia, 
Magnolia, Primula, Gentiana and Meconopsis. Thus for the rest of his life Balfour's research followed two lines: the systematisation of this new Chinese material-making himself one of the foremost authorities on the vegetation of Western China; and the solving of the problems of its successful cultivation in Edinburgh, and in Britain generally. In the naming of the material he wisely enlisted the co-operation of members of his staff, such as Smith, Evans, Orr and Tagg, as well as of other workers abroad, for the detailed study of particular groups, whilst he gradually concentrated his attention on the two great genera Rhododendron and Primula, of both of which he became the acknowledged master, as his many papers in the TRANSACTIONS OF THE BOTANICAL SOCIETY and in NOTES FROM THE ROYAL BOTANIC GARDEN, EDINBURGH, and elsewhere, abundantly illustrate. And, with the object of solving the problems of the successful cultivation of the material, he not only built his great Rock Garden and designed some of his new conservatories, but paid visits to China and Japan in 1909 and I9I0, there to acquire for himself a first-hand knowledge of Eastern Asiatic cultural conditions. The experience and knowledge he gained he put at the disposal of gardeners in I9I2 in the two notable Masters Memorial Lectures he delivered to the Royal Horticultural Society, on Drought and Gardening and on Problems in Propagation.

In his plant propagation lecture, Balfour admitted that he had drawn largely upon the work of Laurence Baxter Stewart (Plate xb), 'the enthusiastic plant propagator, whom I am so fortunate as to have on my staff'. From I90I, when Stewart joined the Garden staff having served an apprenticeship at Kirriemuir where he was born in I876, Balfour had been the dominating influence in his life. As foreman of the Glass Department from I90I until I9II, the supervision of the supply of teaching material for the University classes had fallen to him and had afforded ample contact and scope for discussion with the Professor. In I9I I he was appointed Plant Propagator and, until his death in I934, after two years in the office of Curator, succeeded in propagating many plants which previously had resisted all attempts to propagate them vegetatively, often collaborating with members of the University Botany staff in the publication of his results.

A great botanist, Balfour won recognition as such: elected a Fellow of the Linnean Society in I875 and on the Council from I884-85; elected a Fellow of the Royal Society of Edinburgh in 
I877, and on the Council from I888-9r; elected a Fellow of the Royal Society of London in I884, and on the Council from I892-94; President of the Biology Section of the British Association at Oxford in 1894 and President of the Botany Section of the Association in Glasgow in 1903; Honorary Degrees of LLD from the Universities of Glasgow and Edinburgh. Likewise did he win recognition as a great horticulturist when he was awarded the Victoria Medal of Honour by the Royal Horticultural Society in I897-this even before his greatest contributions to horticulture had been made.

No one whom we have met understands plants as he does. He comprehends them as individuals, each with its peculiar idiosyncrasy, and he understands them as members of a vast community. Of him it may be said in truth, as in a larger way it was said with irony of Lord Bacon, that he took all plant knowledge as his province. Profundity without pedantry is the characteristic of his knowledge. His mind is a great store of the facts of biological science and of plant life, which it has always been his habit to put freely to the use of his colleagues.

Such was the verdict of the leader writer in the GARDENER'S CHRONICLE on his retirement in I922-shortly after he had been created KBE.

When Bayley Balfour resigned the posts he had occupied with such distinction be left the more rigorous climate of Edinburgh to live at Courthill, near Haslemere. Too ill to meet his staff who had subscribed for a presentation to him-and to Lady Balfour-he wrote to them as follows:

To no man holding public office can there come a life of greater happiness than it has been my lot to enjoy for so many years in Edinburgh, where I have found so much real reward to deeds in doing them, feeling all the time that in the mutual work that occupied all of us as Members of the Staff I as leader had the confidence, respect, and esteem of you my co-workers. This gives me many happy recollections to take with me into retirement. And now your good-heartedness and kind thoughts set seal in tangible form to that belief which I ventured to encourage and which has supported me here. These gifts will always be before me, recalling happy times which neither I nor you, I believe, would wish to forget. It is thus they touch in true harmony.

If I may say so, you have chosen in the form of your gifts to me a sequential combination most fitting. Through the pipes you afford me aids to contemplation during absorption of that soothing weed which bids fears avaunt and unpercheth care. In the beautiful camp walking-stick you provide me facilities suited to my ailment for resting during contemplation, and the hut secures that I have shelter and quiet for consummation of thought. 
I feel that never a day will they be absent from my sight, and I shall always be thinking of the times past and all of you who have been so generous in the expression of your desire that the link should not be wholly broken.

He certainly did not intend the link to be broken for, though in shattered physical health, it was his will to continue to work on Chinese plants-and on other matters. Of his plans for the future on leaving Edinburgh he wrote to his friend Thiselton-Dyer on 24th April r922:

The new Keeper will have two interesting things to carry out. It was bad luck that I collapsed when the negotiations were on completion. Lord Airlie is allowing us to have the sanctuary of the Caenlochan Deer Forest in which to make an Alpine Garden. Bulley is financing. The spot is ideal. How I wish we had had such a place going to have taken you to it on one or more of your northern pilgrimages. The other business is-the Forestry Commission offered me as much area as might be necessary in one of their suitable forests for the planting of Rhododendrons. The one I had in view was on the west coast near Ben More. The Rhododendron planting will be quite within easy reach of Glasgow and should be very attractive. The action has, I am glad to say, stimulated the Glasgow Corporation to make use of the extensive area that belongs to them along the shores of Loch Goil. All this to the good. But I hate to drop out of it just when success is achieved_-and indeed but for the engineering of these schemes chiefly I should have bid my adieu at once on settlement after the war with the prospect of a good time in retirement from work. I am trying in bed to arrange papers for a completion of a history of the Edinburgh Botanic Garden-begun many years ago-from which if I achieve it I look for much pleasure and none greater than in the telling of what it owes to you.

Though the great west coast rhododendron garden was splendidly developed by his successor, the Caenlochan alpine garden did not materialise; and neither did the history of the Royal Botanic Garden, the present story being but a shadow of the fascinating account Balfour would have written had he been spared. Regrettably he died on 30 th November-St Andrew's Day-r922.

For the rest let his friends and contemporaries speak of him:

The loss to a science of an acknowledged leader is all the greater when, as in the case of Bayley Balfour, leadership is imposed, and when, as in his case, what a leader does affords a clear index of what the leader is. An outlook as wide as his instinct for the essential was unerring; an enthusiasm as keen as his patience was unwearied; an interest as catholic as his attention to detail was exact enabled him, during a critical phase of botanical history, to blend what was valuable in an order that was passing with what was vital in a new. Knowledge as precise as it was extensive, which ranged far beyond the bounds of his especial science, diction as lucid as the thought that inspired 
it was clear, enhanced the value of his judgment on technical questions and on their relationship to life and affairs. His personal qualities rendered him equally effective as a teacher of those ambitious to promote and those anxious to apply natural knowledge; they endowed him with the still rarer gift of ability to employ botanical facts in furthering the intellectual development of pupils for whom his science was only an item in a prescribed curriculum. Botanists devoted to the study of the natural history of plants know that Bayley Balfour was a distinguished systematist, whose memory will survive in his descriptive work. Yet it does not surprise them to learn that competent students of the plant as a mechanism regard Bayley Balfour as one of the most effective investigators of plants as living things. This judgment helps them to solve a difficulty that confronts them when trying to form one of their own. They are aware that the work of Bayley Balfour when dealing with his material from Rodriguez and Socotra was unlike his work on Chinese plants. The dissimilarity is due to divergence in method, not to any difference in quality. The reason is plain. In his treatment of the materials from the Indian Ocean, Bayley Balfour, with only botanical requirements in view, gave to plant characters that indicate affinity the attention which is essential to the elucidation of system and is desirable for the discussion of distribution. In reducing his Chinese material to order, Bayley Balfour, with gardening requirements in mind, gave to plant characters that facilitate diagnosis the attention which is advantageous in the discussion of plant association and is necessary where botanical information is put to industrial use. He was, like his father, guided by the precept that 'system should be subservient to, not the main object of, pursuit'. This did not lead him, as it had led Hutton Balfour, to avoid descriptive study; it caused him to vary his method of working in accordance with the purpose of his work. This accounts for the value of Bayley Balfour's Chinese results, and may explain why those interested in taxonomic study for its own sake took so long to appreciate the importance of his Chinese studies. ${ }^{\text {I }}$

Such was the judgment of his friend Sir David Prain, whilst another, F. O. Bower, had this to say:

His friends had hoped that he would have been able to use his retirement in writing a comparative and systematic treatise on the Flowering Plants. I say advisedly that no man living could have done this as he could from firsthand knowledge, wide and deep, and regulated by grasp of principle and mature judgment. Moreover, his experience as a systematist was unrivalled. But it was not to be. He had worn himself out in the service of others. That wonderful resistant and elastic fibre had been strained beyond the limit, and was past recovery. Already in the summer of I92I the silver cord was loosed and the golden bowl broken.

In all the gallery of Scottish botanists, whose portraits and whose lives Balfour knew so well, there never was one like him-so catholic in his tastes, so willing to help others, and so able to do it from his ample store.

I PROC. ROY. SOC., B. Vol. XCVI (1924), p.xvi. 
Landowners, horticulturists, foresters, and farmers, as well as specialists in pure science, looked to him for advice and acknowledged its worth. Truly, if ever there was one, he was in the fullest sense of the words 'The King's Botanist in Scotland'.

I PROC. ROY. SOC., EDINB., XIIII (1923), p.236. 


\section{(2)}

\section{CHAPTER EIGHTEEN}

\section{William Wright Smith}

DURING THE THIRTY-FOUR YEARS JOHN HUTTON BALFOUR had been in charge of the Botanic Garden, its prestige had increased enormously. During the thirty-four years Isaac Bayley Balfour had been in command, it had developed into a scientific institution of the first order. During the thirty-four years William Wright Smith was to be in control, he was to maintain and develop the Bayley Balfour tradition.

When he retired, Bayley Balfour was anxious that Wright Smith should succeed him, and on I3th February 1922 wrote to him as follows:

I am, and naturally, supremely interested in the question of the choice of my successor .... - -anxious, yet full of hope, that this great national institution, built up on the solid foundation laid by my predecessors of a compact, now, I trust, definitely cemented, between Crown and University, shall have as Chief one whose education, training, and experience have been such as to give him a wide look upon Science generally as well as upon Botany. Your position here for so many years gives you a title to an expression of opinion from me upon your qualifications, and I have pleasure in giving it.

The appointments which I am resigning are a unique combination and make Edinburgh a teaching centre different from others in the countryUniversity interests in the ordinary sense and National interests have alike to be considered. The Botanic Garden, with its equipment and maintenance by the Government, apart from the University, affects the whole atmosphere, asking that the Chief shall be a Systematic Botanist before all things, trained in administrative work, with knowledge of the Plant World, gained by tropical exploration, in full sympathy with and informed to press the many applications of Botany, and withal an expert laboratory worker and experimentalist as well as a stimulator of research.

From this standpoint I have read with care your life-history, which shows that you are one of those who have a sane and sound view of proportion to devotion to Botany. If I may appraise by items: 
(I) Systematic Botany is your special line, and in it you are a master. Not of it merely as descriptive science, but radiating a brilliant appreciation of correlation and the evolution of plant-form in fitting the world of plant-life for its purposes. In relation to this, your travels and exploration have given you first-hand knowledge of tropical vegetation.

(2) In union with this Systematic side you possess wide and precise knowledge of methods of experimental and analytical laboratory work; in your teaching experience you have put these in practice for instruction and also for research.

(3) As a teacher you have had experience in the control of Elementary and Advanced Students, and in guiding research. Few have had the opportunity of dealing with such large classes both in lecture hall and laboratory. And here I may interpolate that from personal knowledge I can witness to your success. To a vast store of initial enthusiasm, and a corresponding plentitude of patience, you add the gift of lucid exposition and of timely reference which impress your hearers and infuse them with pleasure in listening. Thoroughness marks your efforts in the laboratory, and your aptitude for taking pains in preparation overcomes difficulty. Germane to your teaching experience is your service as examiner in Edinburgh and elsewhere, through which you have obtained an insight into varied methods of teaching and educational work.

(4) Your administrative experience is great. It carries its own record of success, and to this I may add my personal testimony born of our association here since I9II. And what can I say, save that as an administrator, whatever be the sphere, you would not be found lacking, nay more, would certainly succeed, for you possess the equable temperament and that inestimable power of making friends by which you carve paths for overcoming obstacles.

Having regard to all the issues, I cannot but feel that your life has been one which has specially fitted you to be Chief of this establishment, both on the University side and on the Garden side. I should be confident were you installed that while the traditions of the past would not be forgotten, they would not be allowed to stand in the way of progress. A successful future would attend under your guidance....

Not surprisingly, Wright Smith included Bayley Balfour's letter in his application to the Secretary of State for Scotland for the posts of Regius Professor of Botany in the University of Edinburgh and of Regius Keeper of the Royal Botanic Garden. And, not surprisingly, his application was successful. Balfour was content, believing that, under Smith and his supporting staff, the fortunes of the Garden and of the University Department of Botany working in the Laboratories in the Garden, could do no other than prosper.

For his part Wright Smith (Plate XIa) had no illusions about the exacting nature of the duties attaching to the dual post; no illusions about the great scope for botanical research in, and for the further 
development of, the splendid establishment he had inherited from his predecessor-new laboratories for teaching and research, new glasshouses, and a Botanic Garden planted in a definite systematic order.

In the University Department of Botany he was magnificently supported not only by his colleagues of long standing, $\mathrm{M}$. Wilson and J. L. S. Smith, but also by two members of staff Balfour had appointed towards the end of his tenure of office, James Robert Matthews and Robert James Douglas Graham. Matthews had been associated with Balfour since his student days in the University of Edinburgh. Since his student days he had also been closely associated with the Botanical Society, reading his first paper to the Society on Some British Hybrid Roses in 1910. In I9I3 he had been appointed Lecturer in Botany at Birkbeck College, University of London, had worked as a protozoologist during the 19I4-18 War, and had joined Balfour's University staff in 1920. As with Balfour, Smith expected that his University staff should be first and foremost able teachers, and from this point of view none was to serve Smith with more distinction than Matthews who, until 1929, taught the whole of the first year class and almost everything except plant physiology, mycology and the systematics of flowering plants to the second and third year students. In 1929 he was appointed to the Chair of Botany in the University of Reading and in 1934 to the Chair of Botany in the University of Aberdeen-and always maintained a close association with the Edinburgh Department and Garden, especially through the Botanical Society, which, to honour bis 70th birthday, in 1959, published a special volume of its TRANSACTIONS. Matthews, of course, was more than a teacher, for he was to make valuable contributions to plant scienceespecially to the origin and distribution of the British flora.

Graham was invited by Balfour to join his staff in I92I, as Lecturer in Plant Physiology. A graduate of St Andrews, Graham had had experience in the Indian Agricultural Service, and during the First World War as Director of Agriculture in Mesopotamia. Over the years, until I934 when he was appointed to the Botany Chair at St Andrews, he was to serve Wright Smith well, having charge of the large classes in elementary botany, as well as being responsible for more advanced training in plant physiology, plant breeding and genetics. Teaching apart his main interests lay in the activities of the Botanical Society, which he served as secretary, and as President, and in the propagation work of L. B. Stewart. 
In fact it was in large measure duc to Graham's collaboration with Stewart that the latter's work was made more widely known to the botanical and horticultural public.

On the departure of Matthews to Reading, Wright Smith appointed Alexander Nelson, chicfly to teach plant physiology and agricultural botany. A Glasgow graduatc, with agricultural experience in Tasmania, and commercial experience with Messrs David Bell Ltd of Leith, during the course of the next thirty-nine years Nelson's teaching was to cover much more than plant physiology. Towards the end of Smith's regime, by which time Nelson was Reader, he had charge of the instruction to the large number of medical students who still attended an early morning class at the Botanic Garden during the summer term for a grounding in elementary botany. When Graham moved to St Andrews, Smith appointed to Edinburgh one of his former students, John Anthony, who had had administrative experience in Malaya and had worked on some of Forrest's herbarium collections. Although originally appointed to teach forest botany, gradually he was required to cover several other botanical fields-especially that of the cryptogams.

At the time of Wright Snith's appointment the two senior members of the gardening, or horticultural, staff were, of course, Harrow and Stewart. Harrow had been appointed by Balfour to take charge of the glasshouses in 1893 and had filled the office of Curator, with great distinction, since 1902. Thus for twenty years he had become familiar with the great collection of plants, both under glass and in the open, and had assisted Balfour in the many developments in the Garden during this period. Stewart, too, had known the collection well for twenty years and for half this time had been solving the many problems of successful propagation such a collection presents. Smith was indeed fortunate to have the active co-operation of two such great gardeners.

In 1923, the year after his appointment, Wright Smith made the first of his major changes in the Garden and was prompted to do so by his interest in forestry. During the First World War he had been seconded to the Timber Supply Department as officer in charge of labour for Scotland, and had become very familiar with the work and problems of the Forestry Commission. Subsequently, desirous of promoting the interests of forestry in Scotland, he served for a time on the Scottish Consultative Committec for Forestry. In the early 1920's the Forestry Conmission was faced with the problem of finding a site for a forestry nursery and Wright Smith 
argued that it should be sited at the Botanic Garden. At that time a field grazed by cattle occupied the area between Inverleith Place and the iron railing marking the north side of the Garden. In 1923 this field of some three acres was feued from the Fettes Trust, was incorporated into the Botanic Garden by the removal of the iron railing to Inverleith Place, and was converted into a forcstry nursery. The Forestry Commission agreed to discharge the rent until Martinmas I934. In this nursery experimental plots were laid down and much scientific work was undertaken of great benefit not only to the Forestry Commission but to the Garden as well.

At the same time Wright Smith was negotiating for the collaboration of the Forestry Commission and the Office of Works on another matter. The last twenty to thirty years had been remarkable for the introduction into Britain, especially from the temperate regions of Eastern Asia, of a wealth of species of trees and shrubs suitable for forestry and horticultural purposcs. It was conceivable that many of these would prove of economic importance in forestry devclopment. Unfortunately their growth and correct culture could not be adequatcly appraised in the existing State Gardens owing to proximity to town conditions. For instance, conifers generally do not flourish in urban areas and Bayley Balfour, during the last ten years of his Regius Keepership of the Garden, had felt keenly the want of some place where these plants could be cultivated under conditions favourable to their development. He had realised however that the purchase of such an area, its maintenance and control from the Botanic Garden, would necessitate an expenditure which in the circumstances of the time he did not feel was justified. But the establishment of State Forestry in Scotland had brought an opportunity which had commended itself strongly to him as in the first place it afforded a means of securing such an area at no additional expense to the State, and in the second place brought him in touch with a Department whose interests were akin and to which the results would be of great service in the development of its own legitimate work. The project therefore offered no less inducement to the Forestry Commission than to Bayley Balfour as a horticulturist.

The acquisition of the Forest of Glenbranter, Argyllshire, by the Forestry Commission, as one of their areas for the development of State Forests, made possible the realisation of the scheme. The Commission agreed to place an area of fifty acres within Glenbranter Forest for Balfour's purpose. The ground was intended not only as a trial ground for newly imported conifers and other trees 
in which the Forestry Commission was interested, but also for the establishment of rhododendrons and other horticultural shrubs which would be supplied by the Botanic Garden. Experiments had already been made in planting trees and shrubs which had amply confirmed the suitability of the arca. Balfour retired, and Smith had to negotiate with the Office of Works and especially had to convince this Department that the expense which would be involved was not such as would prove too heavy for the scheme to merit approval.

The area was a narrow glen of great natural beauty situated entirely within the Glenbranter Government Forest Reserve which extended to some 10,000 acres. All arrangements for general control and supervision, roads and bridges, fencing against deer, protection from depredations of game, etc, that were necessary for the upkeep of the Forest itself would serve for the special area and would entail no particular expenditure under these heads. There would be no intention of developing the special area as a formal Arboretum or Experimental Garden. The ground would be planted with conifers and other trees, rhododendrons and other shrubs of horticultural interest, and all would be allowed to develop naturally in sites chosen for their special requirements. Operations for many years would be confined to establishing young plants of many species at the planting season and to clearing away occasional scrub and bracken which might interfere with their development. Nothing would be expended on the purchase of plants. New buildings would not be required. For the purpose of Glenbranter Forest itself buildings were already on the reserve and in possession of the Forestry Commission and, for the limited needs of the special area, accommodation would be available there.

Smith estimated that the maximum cost in which the Office of Works would be involved, for the first five years, would not exceed $f_{200}$ per annum; $f_{50}$ for travelling expenses and $\mathcal{E}_{\mathrm{i} 50}$ for labour. It would be quite unnecessary in the first instance for any permanent employee of the Office of Works to be attached to the special area because the general control of the officers of the Forestry Commission would be sufficient. The co-operation between the Office of Works and the Commission would be similar to that existing in the management of the forest nursery at the Botanic Garden; the special area would be under the superintendence of the Regius Kecper, the Forestry Commission sharing with the Office of Works the general control.

The Office of Works fully supported Smith's scheme, Treasury 
granted the necessary funds, and a start was made in the planting of the great rhododendron garden which Balfour had envisaged and which all agreed should be the Balfour Memorial Garden.

However, before planting had been far advanced, Harry George Younger of Benmore and Kilmun decided to gift to the nation his estate of Benmore, an estate of 10,200 acres continuous with Glenbranter. The greater part of the area, heavily forested, would come under the control of the Forestry Commission. Particularly interested in the Balfour Memorial Garden, Younger suggested that a site for it more suitable than that at Glenbranter might be found on his estate. Smith quickly saw that the Benmore site had several advantages over Glenbranter; it was much nearer to steamer communication, much easier of access to the general public, and there was ample accommodation in the way of buildings. His contention that the climate was more favourable was, and is, open to doubt. The great virtue of Benmore was, however, that it was already fairly fully developed, with many of the conifers, planted by James Duncan, a former proprietor between 1870 and I880, having reached fine proportions. Its main feature was its splendid avenue of the Big Tree of California. It was already worthy of a visit by the general public whereas it was not to be expected that Glenbranter would be sufficiently developed for some fifteen years to be worth visiting by anyone but the rhododendron enthusiast. With the acquisition of the Benmore estate the Forestry Commission would now have jurisdiction along the whole length of Loch Eck and, instead of the Balfour Garden being situated at the far north end of the Loch, Smith suggested that it now be sited in the Benmore policies at the south end, under the same joint jurisdiction as in Glenbranter. All parties were agreeable.

Younger did not completely hand over his estate to the nation until towards the end of 1928 . Then the greater part of the area came under the control of the Forestry Commission, for use, with Younger's former residence, as a training school for young foresters, whilst the policies of some 90 acres, surrounding the house, were controlled by the Regius Keeper of the Royal Botanic Garden, acting on behalf of the Office of Works. In this fashion did the 90-acre Younger Botanic Garden, not the Balfour Memorial Garden, come into being, Balfour being memorialised by the erection of a hut in the nearby Puck's Glen.'

I The hut was transferred to the Younger Botanic Garden in 1969. 
Having placed the Botanic Garden at the service of the Forestry Commission in 1923 , Wright Smith now encouraged the Board of Agriculture to make use of its facilities. Until 1924 the plant pathology of horticultural plants had been more or less omitted from the Board's research and advisory policies. Now, pressed by Scottish horticulturists, the Board decided to initiate a Plant Pathology Branch. There was some uncertainty as to the centre from which the Branch should operate until Smith suggested that the logical centre was the Royal Botanic Garden. Thus in July 1924 Mrs N. L. Alcock was appointed Plant Pathologist and functioned from a room in the Laboratory of the Botanic Garden-at first with no assistance. The major expenses and the control of the Branch were the responsibility of the Board, now the Department, of Agriculture. After various assistants had worked with Mrs Alcock for short periods of time Charles Foister joined her in 1928 and from then onwards splendid work was done in this small department. In this way was born the Plant Pathology Section (Science Services) of the Department of Agriculture for Scotland.

Thus, within a couple of years of his succeeding Balfour, Smith had proved himself to be the successful administrator his predecessor had forecast. The same success attended the teaching of his large University classes. Teaching did not worry him; unlike some other Professors he did not begrudge the time spent in instructing his students; he did not feel that such time would be better spent on his researches. Both had to be done and he would find the time for both. He was a good instructor who really enjoyed instructing. Not only did he train a large number of botanists, some of whom attained great eminence in their profession, but in each student he took a personal and friendly interest no matter whether or not they were to continue in the Honours course. Each year he would take particular pride in mastering the names of all those in the large Medical Botany class. Very often he was able to say to a student "Give my greetings to your father. I remember him as a student in this laboratory in the year .... And once, at least, he was able to send similar greetings to a student's grandfather. Or he might say 'Your father was a good classics man. Do you have Latin? Or Greek?'. And, with a shake of his head, he would mutter 'Pity'. Or again: 'What's your weight? You'll not be so good in the scrum as your father'. In this way, throughout the years, he held the large medical class in the palm of his hand; the rowdiness experienced by some of his colleagues in other departments was utterly unknown to him. 
No matter how heavy the administrative and teaching burden, Smith insisted in finding the time to continue his researches. To name and classify Sino-Himalayan plants almost had been second nature to him since his days in India when he had undertaken botanical exploration into little known regions of the Himalayas, especially in Sikkim, and on the borders of Nepal, Tibet and Bhutan. His two most interesting journeys had been those of 1909 and I9IO which were reported in the RECORDS OF THE BOTANICAL SURVEY OF INDIA. In the former year he had botanised the hitherto untraversed alpine regions of Llonakh on the Tibetan frontier, north of the Kanchenjunga glaciers, at altitudes of over $14,000 \mathrm{ft}$, whilst in I910 he had penetrated the high alpine regions between the Tibetan valley of Chumbi and Eastern Sikkim. During these days of exploration, days which he confessed were some of the happiest of his life, he collected much material for future systematic study and gained an intimate knowledge of the country and of the people. He was aware, when he was at Chumbi in I9I0, that his great friend George Forrest was even then on the Likiang Range in Yunnan; but he did not realise in what measure this circumstance was to shape his future activities.

He had returned to Edinburgh from India more or less at the same time as Forrest's great plant collections of the second expedition to Western China were being unpacked. As a result of his Indian experience the task of sorting out this mass of material was one which Smith was able to undertake with unusual facility. Thus Balfour and he devoted many of their working hours, and most of their free ones, to the systematic analysis of Forrest's beautiful collections. Whilst Balfour concentrated mainly on the two great genera Rhododendron and Primula, Smith endeavoured to encompass the rest. Between the years I9I2 and I92I, he published, in NOTES FROM THE ROYAL BOTANIC GARDEN, EDINBURGH, the descriptions of over 550 species new to science-new species of Saxifraga, Androsace, Delphinium, Gentiana, Codonopsis, Senecio, Aster, Corydalis, Salvia, Cremanthodium, Astragalus, Daphe, Potentilla, Vaccinium, Magnolia, Abelia, Berberis, Jasminum, Spiraea, Lonicera, Cotoneaster, and other good garden plants-as well as a most valuable account of the lilies of China. When he succeeded Balfour in 1922 it would not occur to him that he should do any other than continue to devote his energies to the elucidation of Forrest's collections, and of others such as those of Reginald Farrer and of Frank Kingdon-Ward, who rivalled each other in their search for 
new plants from China and the Himalaya. But he did not cast his net so wide as before. He encouraged the taxonomists on his staff to name the Sino-Himalayan collections and to specialise in certain groups, whilst he immersed himself in the study of Rhododendron and Primula-particularly the latter-and, jointly with Forrest, presented a revision of the sections of the genus Primula to the Primula Conference organised by the Royal Horticultural Society in 1928. This important paper was to be the foundation of a much more detailed examination of the genus, the results of which were published, jointly with $H$. R. Fletcher, in a long series of papers in the TRANSACTIONS OF THE ROYAL SOCIETY OF EDINBURGH and in the TRANSACTIONS OF THE BOTANICAL SOCIETY OF EDINBURGH.

Smith's influence on the taxonomy of the genus Rhododendron is not so generally known and appreciated. Whereas primulas had always interested him and had fascinated him during his travels in the Himalaya, not so rhododendrons. 'I did not devote any time to them', he wrote in the RECORDS OF THE BOTANICAL SURVEY OF INDIA. It was only Bayley Balfour's infectious enthusiasm which induced Wright Smith to take up the threads from his chief. It was fortunate that he did so, for it brought the Botanic Garden in close touch with some of the greatest gardeners of the day-Col F. R. S. Balfour (of Dawyck), Lt Col Stephenson Clarke, Major Dorrien-Smith, Lord Headfort, Sir George Holford, G. H. Johnstone, Sir Edmund Loder, Lord Aberconway, L. de Rothschild, K. McDouall, Sir Herbert Maxwell, Sir John Stirling Maxwell, Lord Stair, J. C. Williams, Sir John Ramsden, Sir Frederick Moore-and many others.

Forrest's Rhododendron collections from the Sino-Himalaya, as well as those of Farrer and Kingdon-Ward, more than any other, had caught the imagination of these British amateur gardeners with many acres of land at their disposal. These men entered into friendly rivalry, germinating their seeds which had been distributed to them from Edinburgh, nurturing their young plants, planting their many acres and holding week-end house parties at which they discussed their plants with their gardening friends. Never before had there been such enthusiasm for any one group of plants. Moreover, these great gardeners, in contact almost daily, first with Balfour and later with Smith, organised themselves wonderfully well. In I9Is they formed themselves into the Rhododendron Society and in 1926 organised their first Show which filled the Old Hall at the Royal Horticultural 
Society's headquarters at Vincent Square, London, and was so highly successful that it became an annual event. To spread knowledge of the behaviour of rhododendrons in cultivation, the RHODODENDRON SOCIETY NOTES were published, in annual parts, forming three volumes containing much information, botanical as well as horticultural. The Society's most important publication, however, was that of I930, THE SPECIES OF RHODODENDRON'.... the lasting monument to the Rhododendron Society, as also it will be to those who compiled it, Mr H. F. Tagg for the lepidote rhododendrons, Mr J. Hutchinson for the elepidote, and Dr Rehder for the azalea series', as G. Johnstone described it in the Royal Horticultural Socicty's I958 RHODODENDRON AND CAMELLIA YEAR BOOK. The aim of the book was to provide a single page description of each species and to attempt to group the species into series. The grouping was admittedly tentative and has had to be revised but the book is still an immensely important one for the student of rhododendrons. Those who were associated with Smith at the time, his colleagues in Edinburgh and his friends the rhododendron enthusiasts throughout the country, were aware of the kind counsel and enormous help he gave to the Rhododendron Society in the preparation of the book and especially of the encouragement and guidance he gave to the member of his staff, H. F. Tagg.

Smith's association with rhododendrons is commemorated in the rhododendron which bears his name. 'William Wright Smith' is a magnificent hybrid between Rhododendron muttallii of Bhutan, Upper Burma and South-Eastern Tibet, and $R$. veitchianum of Burma, Tenasserim and Siam, with trusses of large scented flowers the petals of which are white, stained on the outside with various shades of pink, and delightfully frilled at the margin. This hybrid, suitable for cultivation in a cool glasshouse, was raised in the Royal Botanic Garden and received the First Class Certificate from the Royal Horticultural Society in I960.

Just as Bayley Balfour had found the tasks of administering a large University Department and a Botanic Garden, and of investigating the enormously rich Sino-Himalayan flora, very exacting, so did Wright Smith. The tasks could never have been successfully accomplished, had both men not been willing to work long hours, to forego holidays and to be in some measure 'sheltered', in the seclusion of the Regius Keeper's office, by their devoted secretaries, at first by Jean Brockie and later by Edna L. Linsell 
as well. Even so, in I9II, Balfour had found it necessary to have assistance, especially in the administration of the Garden, and had appointed Smith as Deputy Keeper. In like measure, in I930, Smith also deemed it necessary to have a Deputy in the Garden and secured John Macqueen Cowan (Plate xic), who had recently retired from the Indian Forest Service.

A son of the manse, Cowan was born in Banchory, Kincardineshire, in 1892 , and received his early education at Robert Gordon's College, Aberdeen. Entering the University of Edinburgh in I9IO, and there taking the Arts Course and the MA Degree as well as the Degree of Bachelor of Science with Intermediate Honours in geology and zoology and Final Honours in botany, he then became an undergraduate at Oxford in I9I4, reading botany under Professor Vines and Dr Church, and forestry with Sir William Schlick, before being appointed to the Indian Forest Service. In India he proved himself a Forest Officer of outstanding merit. In the Chittagong district of Eastern Bengal he explored a region of tropical rain forest, monsoon forest and xerophilous woodland, classifying the forest types and determining the factors governing the distribution of the various plant communities, before being transferred to the Kalimpong Forest Division in Northern Bengal as Divisional Forest Officer and Forest Working Plans Officer. Here, for three years, in an area of 250 square miles extending from near sea-level to well over $12,000 \mathrm{ft}$, he again had ample scope for the study of vegetational types, as indeed he had in 1926 and 1927 in the high alpine pasture lands in Sikkim and on the borders of Tibet, when acting as Director of the Botanical Survey of India. In 1927 he published his first major paper The Forests of Kalimpong-An Ecological Account, which was accepted for the Degree of Doctor of Science by the University of Edinburgh. By this time he was holding the chief botanical post in the Indian Empire, Superintendent of the Royal Botanic Garden, Calcutta, the post he had to relinquish on his retirement from India in 1928, the year preceding the publication, with his wife, of THE TREES OF NORTHERN BENGAL. Obviously one with this experience, as well as one with the tremendous energy and drive which was Cowan's, appealed to Smith who considered himself fortunate in securing Cowan's services for Edinburgh.

Once in Edinburgh, with typical enthusiasm he became involved in a detailed history of the Garden using materials which had been assembled by Bayley Balfour. Unfortunately, he was able to take 
the history only until the end of the reign of the Prestons-I738.I There were difficulties with His Majesty's Stationery Office over publication of further portions of the history in the Garden's official scientific publication which prevented Cowan from continuing with this eminently worth-while task. But there was another reason why he did not take the history beyond the Prestons. In $1933 \mathrm{H}$. F. Tagg, who, though officially in charge of the Museum. had been working on the taxonomy of rhododendrons for so long, and who, with Hutchinson of Kew, was regarded as the authority on the genus, died, leaving his work far from finished. Forrest's rhododendron collections from his last expedition (Forrest had died in Yunnan in 1932 when his expedition was almost concluded) still required to be named, as did many of the collections of KingdonWard and Joseph Rock. Moreover, George Sherriff and Frank Ludlow in I933 were collecting in Bhutan, on the first of many subsequent expeditions; their rhododendron collections would be sent to Edinburgh for naming. Cowan had had experience of rhododendrons in the field, in India, and straightway took up Tagg's unfinished work. Assisted in no small measure by several members of Smith's staff, notably, at first, by Helen T. Maxwell and later by H. H. Davidian, Cowan published widely on the taxonomy of this complex genus of which he made a special study for the next twenty years and ensured that Edinburgh remained pre-eminent as a centre of rhododendron research. All who had worked on rhododendrons had shown the prime importance of the leaf covering, or indumentum, in classification and in relationships. Cowan, believing that this character was worthy of closer investigation, made a very detailed study which he published in THE RHODODENDRON LEAF of I950. This was probably his major contribution to rhododendron literature.

The vacancy in the Museum Department, caused by Tagg's death, was filled in 1934 by Harold Roy Fletcher, at that time an Assistant Lecturer in Botany, under Professor Matthews, in the University of Aberdeen. Born in Glossop, Derbyshire, in 1907, Fletcher had graduated with Honours in botany in the Victoria University of Manchester, had been appointed in 1929 to Aberdeen immediately after graduation, and had been required to teach plant physiology and agricultural botany to elementary students, as well as various groups of non-flowering plants to advanced

\footnotetext{
${ }^{I}$ NOTES ROY. BOT. GARD. EDINB., XIX (I933-35), p.I-I34.
} 
students. At that time Professor Craib was deeply immersed in his studies on the flora of Siam and had immense Siamese collections at his disposal. Fletcher gradually also became interested in these collections and, when transferred to Edinburgh in I934, was fully committed to continue with the work on the Siamese flora-work which had suffered a great setback due to the death of Craib in I933.

Unfortunately, or possibly fortunately, once in Edinburgh Fletcher became interested in plants other than Siamese. Both in the Botanic Garden and in the Herbarium he came under the spell of the flora of the Sino-Himalaya-and especially under the spell of the genus Primula of which in the 1930's many species, including many rare ones, were in cultivation in Edinburgh. In the Herbarium there were the enormously rich collections of Forrest, Farrer, Kingdon-Ward, Rock-as well as a fair representation of the collections of the Frenchmen, Delavay, David, Soulié and Fargesand the new, beautiful material gathered by Ludlow and Sherriff in Bhutan and South-East Tibet had begun to arrive in Edinburgh for Smith's study. Here was a genus which, like Rhododendron, required to be monographed, and Fletcher, abandoning his work on Siamese plants, began the collaboration with his chief which was to result in a long series of papers, on the various groups of Primula, which were to be published by the Botanical Society, and by the Royal Society of Edinburgh.

Shortly before Fletcher arrived in Edinburgh in 1934, R. L. Stewart, the Curator, died. Stewart had been in the office of Curator since Harrow had retired from Edinburgh in I93 I to take over the onerous position of Director of the Wisley Gardens of the Royal Horticultural Society, after having served the Edinburgh Garden for thirty-eight years. During these years he had witnessed, and in large measure had played a part in, enormous changes in the Garden; great developments in the planthouses, the Arboretum-the whole western portion of the Garden, the Woodland Garden lying to the west of the Rock Garden and, of course, the Rock Garden itself. One of the most recent changes, initiated shortly before he retired, was the construction of the moraine, or scree, near the northern approach to the Rock Garden. It was designed essentially for the cultivation of plants requiring very sharp drainage. The soil was excavated to a depth of between two and three feet, and the cavity filled with rough boulders overlaid with granite chips to a depth of about eight inches. There was practically no soil on the moraine and plants from dry areas, especially those of the cushion type, 
which resent damp at the collar, already were growing exceedingly well. Forrest, very familiar with the moraine habitat during his travels, had advised on the construction and had approved of the result. For four years, Stewart had had a personal assistant, Roland Edgar Cooper (Plate XId), who now, at Stewart's death, succeeded to the Curatorship. Born in I89I, at Kingston-on-Thames, Cooper had lost both parents before his fourth birthday. Until he was sixteen, guardians provided for him; then there was a change in guardianship, William Wright Smith taking charge; from this time forth the two were to work closely together.

When Smith was appointed to the charge of the Government Herbarium in the Royal Botanic Garden, Calcutta, Cooper accompanied him to India and it was this Garden and the influence of Smith which helped to shape Cooper's future career. He accompanied Smith on the latter's journeys of botanical exploration in Sikkim and on the borders of Nepal, Tibet and Bhutan, and thus was able to appreciate the richness of the floral treasures of the high alpine regions of this part of the world. In rgro Cooper returned to Scotland with Smith and took the course of horticultural instruction at the Botanic Garden. Even before his course of study was finished he was persuaded by Balfour and Smith to undertake botanical exploration in the Himalayas, on behalf of Mr A. K. Bulley of Cheshire, who had already launched Forrest and Kingdon-Ward as plant collectors. In the Himalayas, especially in Bhutan, he discovered many new species-chiefly rhododendrons and primulas. Probably his most interesting discovery, however, was that of the sole Asiatic and European representative of the African giant lobelias, Lobelia nubigena of Bhutan.

After the First World War, during which he was commissioned in the Indian Army, Cooper was appointed Superintendent of the Botanic Garden at Maymyo in the Shan Hills of Burma. Probably this was the happiest period of his life, for he loved the Burmese and their ways, and was loath to return to Scotland, for the education of his son, at the end of the 1920's.

In Edinburgh, Cooper was well served by bis horticultural staff; by his assistant, David Wilkie, who had previously been a foreman in the Garden, and by the foremen of the various departmentsWilliam Gregor MacKenzie in the Rock Garden and Herbaceous Department, Charles Lamont in the Arboretum, James John Campbell in the Glass and Edward Edmund Kemp in the important Propagation Department to which Stewart had brought so much 
renown. The scene was set, and the time was ripe, for important developments in the Garden.

In the I830's, in the time of William McNab, there had been in cultivation in the Garden a splendid collection of heathers native to South Africa. McNab had solved the problem of their successful cultivation, under glass, in Britain, and an entire glasshouse had been devoted to their culture-for at that time they were very popular horticultural plants. Gradually, however, they lost favour with the horticultural public and in the early 1930's only a few of $\mathrm{McNab}$ 's specialities were in cultivation in the Edinburgh glasshouses. But heaths of another kind were being grown, and indeed were in great demand by gardeners all over Britain; heaths not from South Africa but from Britain and Europe. In the Botanic Garden there was a small collection of these opposite the west end of the planthouses, below the terrace. The collection, however, was not nearly representative enough and never could be representative on that site. Consequently, about 1935, a new Heather Garden was laid down, on a site immediately east of the Rock Garden. Thousands of plants were propagated: the many forms of the variable Ling or Heather Calluna vulgaris, common throughout the British Isles on heaths and moors, especially in acid soils, and occurring in Europe from Iceland and Finland, to Spain, Italy, Greece, and the Urals; the many forms of the Bell-heather Erica cinerea, which in many parts of Britain runs riot, over the Highlands of Scotland, the mountains of Wales and on the moors of Devon, Cornwall and Somerset, and is also found in Western Europe from Norway and the Faroe Islands to N. Spain, Portugal and N.W. Italy; the many forms of Erica carnea, wide ranging in the mountains of Central and Southern Europe; the less variable Cornish Heath Erica vagans; the Mediterranean Heath Erica mediterranea; Erica $\mathrm{x}$ darleyensis, a hybrid between the Mediterranean Heath and Erica carnea; various forms of the Spanish Heath Erica australis; Erica arborea, the Tree Heather of Southern Europe, North Africa and the Caucasus, and Erica terminalis, the tall-growing heath from the region of the West Mediterranean. Thousands of all these plants were planted informally with junipers, pernettyas and brooms and bulbous plants such as crocuses and squills. There is variety and colour every month of the year in the Heather Garden, which from the time of its construction has been one of the most popular parts of the Garden.

Changes elsewhere in the Garden were made necessary not by 
PLATE XIII

(top) The Herbarium

(centre) The Library

(bottom) The Laboratory
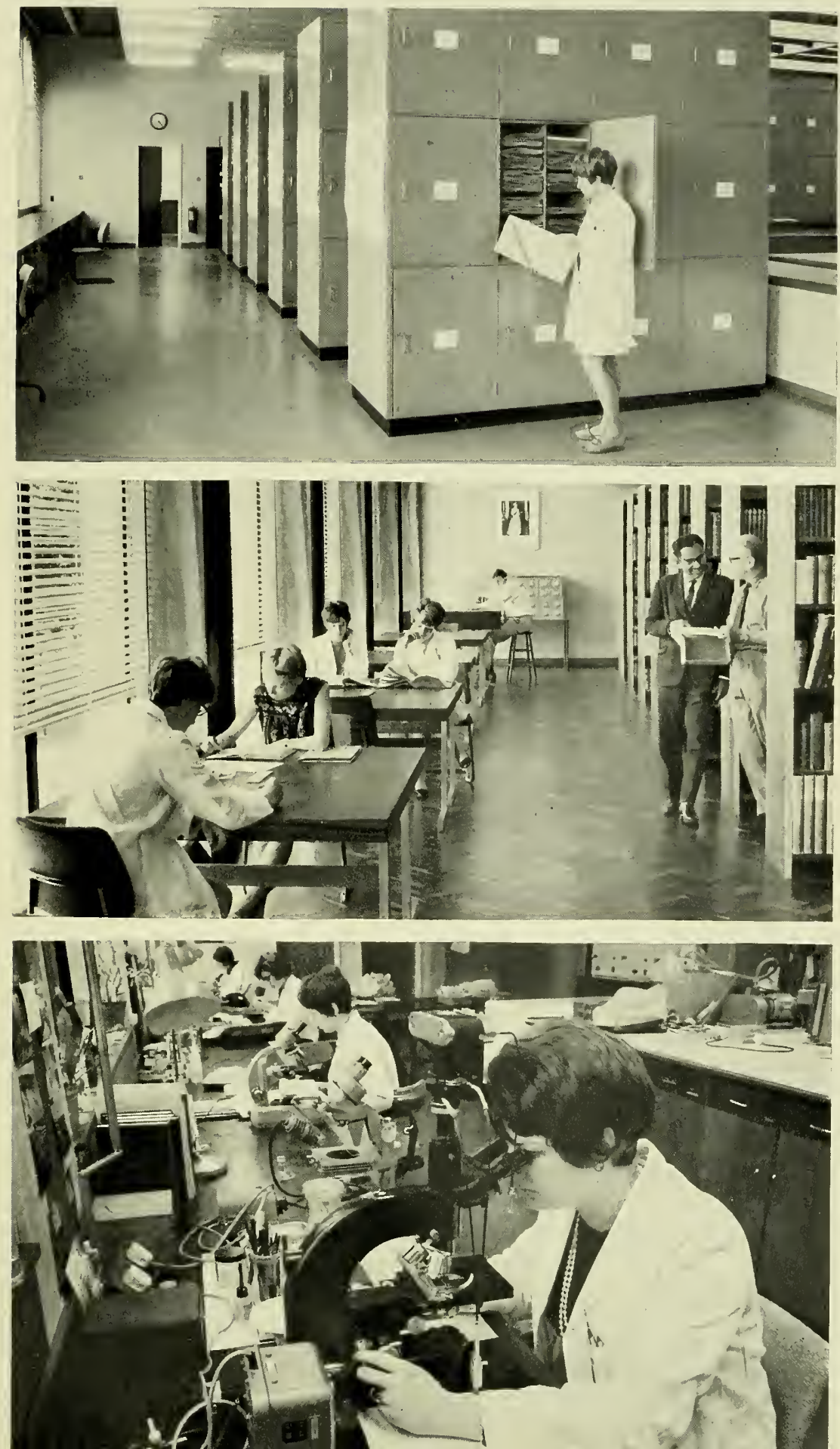


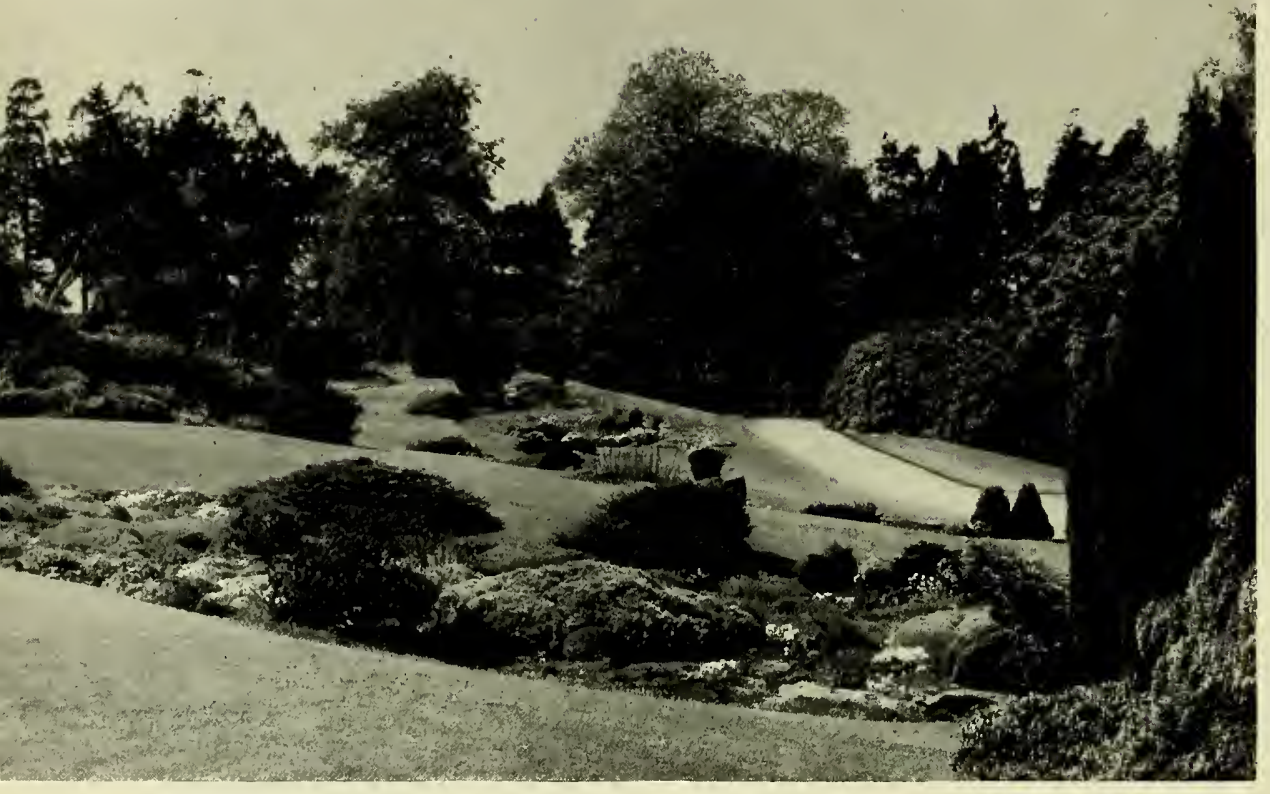

(a) The Rock Garden : the North face

(b) The Rock Garden (compare Plate viII)

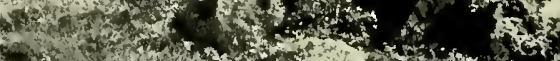

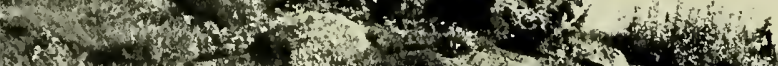

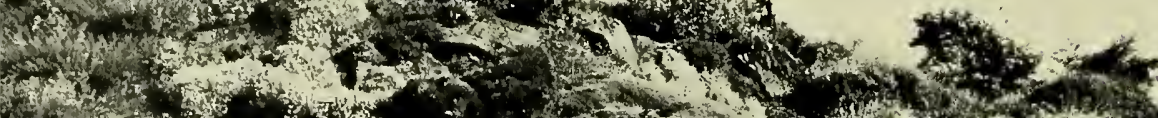

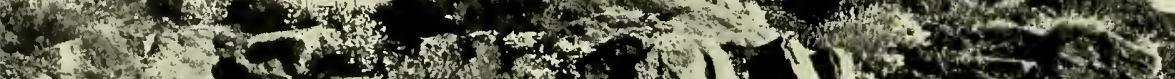

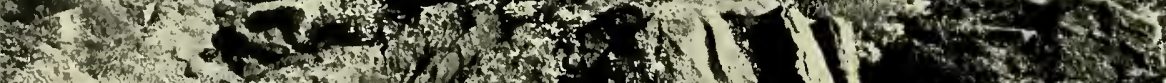

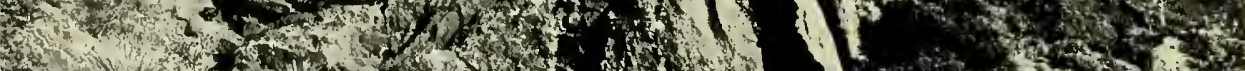
T.t.

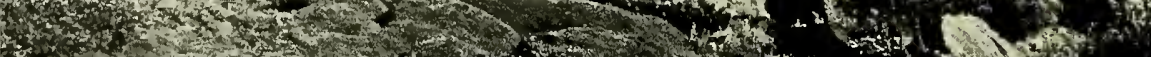

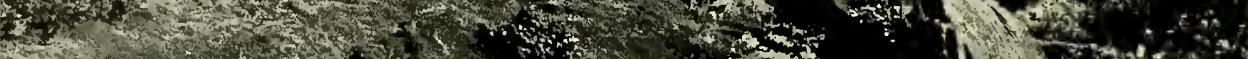

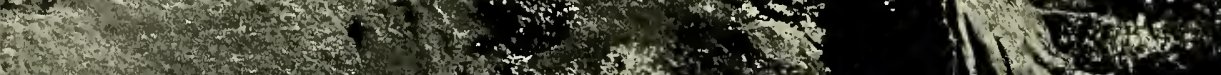
H.

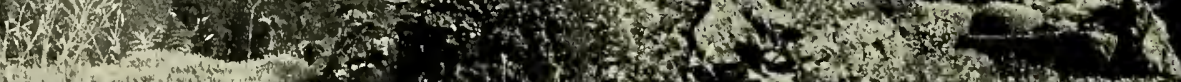
1.

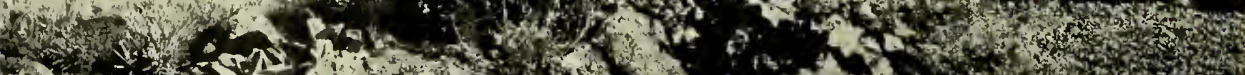

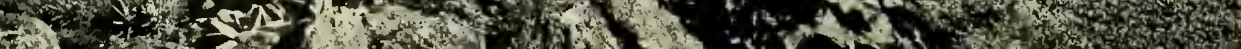


the popularity and garden usefulness of a particular group of British and European plants but by the great mass of Sino-Himalayan plants of every type-rock garden plants, herbaceous plants, trees and shrubs-which had been raised in the Propagation Department and for which accommodation had to be found. It was for some of the plants suitable for the Rock Garden that the north-facing moraine was built. Later, another moraine was constructed on the south side of the Rock Garden when the entire south bank was redeveloped in 1937-38. Ten years later, at the west side of the Rock Garden, a long bed of gravel was designed to simulate the dried up course of a river now in process of being colonised by plants. In the construction of all of this, a member of the Garden staff with a flair for rock work, Jack Roberts, played a prominent part. Roberts had been one of Smith's student gardeners, or probationers as they were then called, before being appointed to the permanent gardening staff. In 1946 he became a member of Smith's University staff, first as Assistant Lecturer. Later, as Lecturer, he taught botany to first year students until his early death in I960. He proved a most popular lecturer and very appropriately the Jack Roberts Memorial Prize (in books) was established in 1962 and is awarded to the best first year student in botany.

Experience showed that not all Sino-Himalayan alpines found the rather dry and warm conditions of the Rock Garden completely to thcir liking. Certain primulas, lilies, gentians, meconopsis, ericaceous plants and others obviously demanded cooler, more moist conditions. To accommodate such plants, 'rooteries' were constructed on the fringe of the Woodland Garden (a development of the Arboretum)-old tree stumps partially buried beneath a peaty compost. For a time many plants grew well in this environment until they and the old tree stumps became infested with Honey Fungus

The Peat Garden, substitute for the 'rooteries', was much more successful-so successful indeed that it was soon extended on to the site of the old 'rooteries'. Constructed in I939 at the north entrance to the Woodland Garden, the series of raised borders, rich in peat and supported by peat turves to produce irregularly shaped terraces, allowed of the successful cultivation of dwarf rhododendrons and their allies, many primulas, gentians, lilies, meconopsis and much else. Copied from the Peat Garden created by the McDouall brothers in their garden at Logan in Wigtownshire, the Edinburgh Peat Garden has since been imitated in many another garden. 
Accommodation for the many rhododendrons and other trees and shrubs had to be found in the Arboretum. In this way the present Woodland Garden and Copse took on their present form, whilst many more rhododendrons were added to those which had been planted, in the early days of Bayley Balfour's Keepership, in the shelter of the yew hedges partly encircling Inverleith House. In fact, the numerous rhododendron plantings gradually changed the character of the Garden. Never very formal in nature, it now became delightfully informal, especially in the vicinity of the Woodland and Copse where, with winding grassy paths and rhododendrons growing under the light canopy of Scots Pine, oak and birch, visitors still find it difficult to realise that they are so near to the heart of the city. Apart from the rhododendrons, thousands of other trees and shrubs were planted along the entire south side of the Garden and throughout the Arboretum, as a result of which Balfour's arrangement of plants in related groups tended to be somewhat obscured.

Naturally, even more than the Edinburgh Garden, the Younger Botanic Garden at Benmore profited from the woody SinoHimalayan material. At Benmore there was abundant space for the thousands of rhododendrons which Smith sent from Edinburgh and which responded so well to the Benmore climate of over 90 inches of rain annually. In the I930's both Smith and Cowan were regular visitors to Benmore, Cowan finding there the additional attraction of excellent fishing.

Such was the Garden in 1939, when, with war with Nazi Germany seeming inevitable, it was concerned with developments of another kind. Throughout the country preparations for Civil Defence, referred to as 'Air Raid Precautions', had begun, and in the Garden plans were made for the protection of the staff and members of the public. Sand-bag baffles, brick walls and timbered reinforcements were hastily erected at vulnerable points. Air-raid shelters were constructed and anti-gas devices hurriedly improvised to meet the sombre threat of modern warfare. Those members of the staff exempt from military service were enrolled in the Civil Defence organisation, some to act as Wardens, some to control in the event of emergency, and others to form the nucleus of a Firstaid Detachment. To combat fire, squads of fire-fighters were mobilised and instructed in the use of fire appliances. A Control Room was established in the Garden office, to act as the nerve centre of the Civil Defence scheme, and ARP instruction courses 
and exercises became a recognised part of the daily routine of the Garden staff.

As the war developed, the Ministry of Home Security instituted a compulsory system of fire-watching in which everyone not specially exempted was compelled to do duty as a Fire Guard for a period not exceeding 48 hours in each month. All available members of the staff consequently had to undergo a course of training in fire-fighting methods. Persomnel, including women, when trained, were grouped into squads, each under a leader, and a nightly quota did duty during 'black-out' hours, the men in the Laboratory, the women in the Regius Keeper's office. Happily, the organisation was never put to the final test. Throughout the war the Botanic Garden remained unscathed, the only damage being a few panes of glass broken by falling fragments of antiaircraft shclls.

Even so, the times were desperately anxious and exacting ones for Wright Smith and his greatly depleted staff with which he had to maintain the Garden and to continue to teach his University and Garden students. For the duration of the war he lost the services of his Deputy, who was seconded to the Home Grown Timber Production Department of the Ministry of Supply as Divisional Officer for the West of Scotland with headquarters in Glasgow. In this capacity Cowan built up a large production organization, with over thirty operational units which varied in size from some twenty to several hundred workers, supplemented by students, schoolboys and others, by units from Newfoundland and latterly by German and Italian prisoners of war. Cowan's tremendous energy and drive never stood him in greater stead than during these years of the war.

Anthony, of the University Botany staff, was also seconded to timber production.

As much as these, Smith missed the services of the man in charge of the Garden's Propagation Department. E. E. Kemp (Plate xIIa) had not only upheld the great traditions of this Department but from 1935 had endeavoured to place it on a sure scientific foundation. During the war he served with the Royal Artillery and was commissioned in I943. Having previously worked in the Berlin Botanic Garden in 1936, and again in 1939, his knowledge of the German language proved invaluable, since, because of this, in 1944 he was transferred to Force 134. And the following year he was an interpreter in the Operation 'Apostle' herald party which was flown to General Boehme's Headquarters in Norway. 
Smith never ceased to be grateful to those of his staff who helped him to hold the fort during these difficult years; grateful not only to the members of his teaching and research staffs but to those who for many years had been holding positions of less seniority; Daisy Drysdale in the Herbarium since 1904, Ella R. Stott in the Laboratory since I9I3, Helen Maxwell (later Miller) working chiefly with rhododendrons since 1925 , and the clerical officers, Jean Brockie since 1908, David R. Oliver since I9II, Edna L. Linsell since 1924 and George F. Reid since 1927. Neither did he cease to be grateful to those who left the Garden to enter the Forces, some, by so doing, giving their lives. Just as it had been Bayley Balfour's wish to have a bronze plaque erected in the Laboratory to commemorate the names of those who had died in the 1914-I 8 War, so was it Wright Smith's wish that a similar plaque be erected after the 1939-45 War.

The years following immediately on the war were no less trying ones for Smith for he was to lose the services of many of the senior members of his Government staff, chiefly through retirement. W. E. Evans, in fact, had retired in November 1944 and H. R. Fletcher had taken over the responsibility of the Herbarium. In July I946, J. T. Johnstone retired from the Library and, until a replacement could be found, Dorothea E. Purves who had assisted Johnstone, ably took charge. Finally, M. Y. Orr severed his long association with the Garden-especially the Laboratory-in December I947, and R. M. Adam his even longer association, two years later.

With the exception of that of Evans, these retirements followed the reorganisation of the Scientific Civil Service on which a Government White Paper was issued in 1945; the proposals therein were implemented by the Treasury the following year. As a result, Smith was given a complement of Officers in the Scientific, Experimental and Assistant Classes. Cowan was ranked as Senior Principal Scientific Officer, Fletcher as Principal Scientific Officer, and David Wilkie, who in 1936 had published his book on Gentians and who for some years had been working in the Herbarium, was appointed Senior Experimental Officer.

Thus, when over seventy, Smith was faced with the task of appointing virtually a new Government staff. Though he regretted the departure of the colleagues with whom he had been associated for so long he was not unduly troubled. His old friends would be replaced by young new ones, who, given experience, would serve him, and his successors, just as loyally, and bring equal distinction 
to the Royal Botanic Garden. He was not to foresee that a young post-war Edinburgh University botany student, Peter H. Davis, who, even before joining Smith's University classes had made large herbarium collections, would in large measure change the future direction of the research work from the flora of the Sino-Himalayas to that of South-West Asia.

There were other retirements and resignations. R. E. Cooper, the Curator, retired in 1950 and his post, one of the most responsible horticultural posts in Europe, was filled by E. E. Kemp, who, following the years of the war, was to find much scope for development in the Garden. In I95I H. R. Fletcher resigned from the staff on his appointment to the office of Director of the Royal Horticultural Society's Garden at Wisley and was replaced by Brian Lawrence Burtt, a distinguished taxonomist from the Royal Botanic Gardens, Kew. Burtt was to spend several years in large measure training, and supervising the research work of, Smith's young and newly-appointed Scientific and Experimental Officers.

After the war, Cowan had become deeply interested in the activities of the National Trust for Scotland and especially interested in the two great Scottish gardens the Trust had taken over-Crathes in Kincardineshire, and Inverewe in Ross and Cromarty. It was he who had inaugurated the early 'Garden Cruises' of the National Trust, a unique and previously unused method of transport by which people from all parts of the world were enabled to visit famous, and often sonewhat inaccessible, gardens in great comfort. In 1954 he retired from Edinburgh and thereby entered into another phase of his career when he accepted the post of Garden Adviser to the National Trust for Scotland. Life in India had suited his temperament immensely; in Edinburgh he had been very industrious and always happy; but it was not until he took up his new post with the Trust, with his headquarters at Inverewe, on that incredibly lovely and rocky peninsula at Poolewe in Ross-shire, that complete contentment and satisfaction came to him. And naturally so, for there, in the surroundings that he loved, he fished; there he sang the praises of one of Scotland's great gardens-and to such effect that the number of visitors to the garden rose steadily from a few hundreds in 1954 to over 60,000 in 1961. Cowan's services to horticulture were acknowledged by the Royal Horticultural Society by the award of the Veitch Memorial Medal in I95I-especially for his work on rhododendrons-and the Victoria Medal of Honour in 1955 . 
To succeed Cowan in Edinburgh, Fletcher returned from Wisley, unfortunately to be associated with his former chief for two years only. For over forty years, thirty-four of them as Regius Keeper, Smith had slaved unsparingly and unceasingly for the University Department and for the Garden, greatly adding to the prestige of both. He had guided the fortunes of the Garden through the difficult years of the war, had experienced the gradual dissolution of the old Government Scientific staff which he had largely inherited from his predecessor, and had, towards the end, assembled around him a group of young energetic taxonomic botanists on whom rested his hopes for the future. ${ }^{1}$ He was now tired and in failing health - and somewhat distressed because of it. Fortunately for him he was not to be thus for long, for he died on I sth December 1956.

Balfour's confidence in him had been amply justified; he had added greatly to our knowledge of the flora of Asia; he had won for the Botanic Garden a reputation for being one of the most beautiful Gardens in the world, noted for taxonomic research and for the successful propagation and cultivation of plants. Naturally his great contributions to botany and horticulture were widely recognised: Knighthood in 1932; Fellowship of the Royal Society in 1945; the MacDougall-Brisbane Prize from the Royal Society of Edinburgh, of which he was President from 1944-49; the Victoria Medal of Honour in 1925, and the Veitch Memorial Medal in 1930, both from the Royal Horticultural Society of which, for many years, he was a Vice-President and its Honorary Professor of Botany and to which in I935 he delivered the Masters Lectures on problems in the classification of plants. He was also an Honorary Member of the American Academy of Arts and Sciences, and held the degrees of DèsSC of the University of Toulouse, and LLD of the University of Aberdcen.

Sir Willian was born in the country and all his life remained a man of the country, detesting cities and crowds. He had loved his days on the high hills of the Himalaya and for long afterwards nothing gave him greater joy than to carry his gun on a long moorland walk or to climb the Scottish mountains in search of plants. In fact, a day's shooting or an alpine excursion, or a visit to a friend's garden in the country, or a game of tennis, was the only

${ }^{1}$ D. M. Henderson, I. C. Hedge, A. J. C. Grierson, L. A. Lauener, J. Keenan, H. H. Davidian, C. Winsome Muirhead, Heather T. Prentice, Rosemary M. Smith, Dorothea Purves, R. Eudall, P. J. B. Woods. 
respite from work he took for many years. When the time came for him to forego these pleasures he was troubled. 'My step was once so light on the heather, now I puff and blow if I climb the hill from the Laboratory to my house.' But during his later years, that which concerned him-even grieved him-most, was the death of an old friend, and his first task of the day on entering his office each morning (Sundays cxcepted) punctually at 8.15 was anxiously to scan the death notices in his newspaper. Often there ran in his thoughts the words from one of Horace Walpole's letters to Horace Mann: 'When one preserves one's senses and faculties and suffers no pain, old age would be no grievance, but for one-and oh! that is a terrible calamity-surviving one's friends.' 


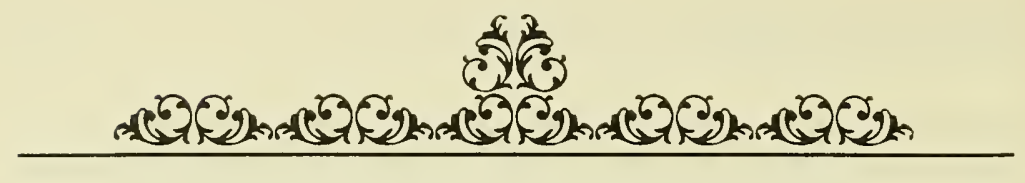

\section{CHAPTER NINETEEN}

\section{New Buildings}

DURING THE LATTER YEARS OF WRIGHT SMITH'S REgIME there had been a heavy increase in the scientific work carried out by the members of the Government staff responsible to the Regius Keeper. In like manner the responsibilities of the Professorship had also increased with the growth of the University Department of Botany. Thus, on Smith's death, agreement was reached between Her Majesty's Minister of Works and the Court of the University of Edinburgh that the posts of Regius Keeper and Regius Professor should no longer be held by the one individual. At the same time, however, arrangements were made to maintain the valuable and historic association of the Botany Department of the University with the Royal Botanic Garden; the University Botany staff continued to occupy the Botany Building at the Garden where they were in daily contact with the members of the Government staff, to the advantage of both, whilst the resources of the Botanic Garden continued to be placed at the disposal of the University.

With effect from I6th December I956, H. R. Fletcher was appointed Regius Keeper (Plate xnb), in the grade of Deputy Chief Scientific Officer, although the Royal Warrant was not granted until 2nd June I958. Not until 1967 was he appointed Her Majesty's Botanist in Scotland. As he was not required to use Inverleith House as an official residence in 1960 the house was converted by the Ministry of Works into the Scottish National Gallery of Modern Art and the adjacent Regius Keeper's office into a refreshment room.

Until the University appointed a successor to the late Professor of Botany, Alexander Nelson acted as Head of the Department. Not until October 1958 was a new Regius Professor appointed, and then a new chapter in the history of botany in Edinburgh was opened. The University Department of Botany had enjoyed a long and honourable tradition of plant taxonomy. The new Professor, Robert Brown, a Fellow of the Royal Socicty, 
was a very distinguished plant physiologist who had made a remarkable series of studies of the development of cells from growing points, first in the University of Leeds, and then, from 1953, in his very active Agricultural Research Council Unit of Plant Cell Physiology at Oxford. Once in Edimburgh he straightway made new appointments to his staff and began to develop a similar school of research. However taxonomy was not neglected for P. H. Davis was appointed head of a sub-department which now vigorously pursues work on the flora of Turkey and offers a postgraduate diploma course in taxonomy, a course in which members of the Government Scientific staff collaborate.

Shortly after Fletcher's appointment, significant changes took place in the Plant Propagation Department. In any establishment where vast collections of plants are grown for reference, teaching, or research, a constant stream of material is required for the renewal of plantings, the replacement of suppressed or short-lived species and for inclusion in the collection of additional items which are likely to be of future scientific interest, or of economic or decorative value. The efficient organisation of such a supply can really only be achieved in suitably designed premises where all the raw materials used are available in correct juxtaposition to each other.

In 1956, three isolated groups of staff and students carried out all the plant raising and potting in the Garden in congested and antiquated premises to which none of the raw materials in everyday use could be transported by mechanical means. Moreover the existing glasshouses in the Propagation Department were widely dispersed, badly sited, and in most cases in a dilapidated condition. Consequently an efficient Propagation Department could be built only by the demolishing of the old and the erecting of new premises stage by stage.

The mainstay of any glasshousc layout is an efficient heating system with thermostatic control. Accordingly, at the outset, the heating plant was modernised. Oil-fired high pressure steam was adopted in place of hot water on account of the greater flexibility and cheaper piping associated with this medium. This allowed the entire heating to be centralised in one unit and two outlying boilerhouses to be dispensed with.

When once the heating plant was modernised, the demolition of a sufficient number of old houses and buildings followed to make way for the first part of a completely redesigned Propagation Department. Apart from new propagation houses with modern 
equipment, and plant-growing houses of new design, the main building to be erected was the Process Building where all the benchwork in connection with plant propagation and raising is carried out and where all the raw materials are prepared. This building, with the Staff Welfare Block adjacent to it, is an integral part of the entire planthouse layout and is but one part of the ultimate development of the Propagation Department. Further development had to be deferred in order that even more pressing building matters could be proceeded with.

The old Exhibition Hall of the Royal Caledonian Horticultural Society may have been adequate for a Herbarium building at the time of the Treasury inquiry in 1890; in 1960 it was utterly inadequate and had been for many many years, its priceless collections of scientific material overflowing into four quite unsuitable huts and other buildings. Moreover, the members of the Herbarium staff were separated from the Library, which was vital to their work, as well as from the rest of their scientific colleagues working in the Botany building, by 300 yards of Botanic Garden. Conditions in the Library were as unsuitable as those in the Herbarium - the vast collection of books and periodicals overflowing from the main Library room into three other subsidiary store rooms-rooms which were urgently required for the work of the rapidly enlarging University botany staff. Under such conditions the work of the Government scientific staff inevitably was severely handicapped.

Thus the provision of a new building to accommodate the Herbarium and Library collections, the scientific staff, senior members of the horticultural staff, as well as the administrative staff, was even more urgent than the further development of the Propagation Department. Such a building was designed in the Directorate of Works, Ministry of Public Building and Works (the name of the Ministry since 1962) by Mr R. Saddler, the engincering services being by $\mathrm{Mr} \mathrm{A}$. Mitchell, whilst much of the fittings and furnishings were provided by the Design Group of the Ministry's Furniture Branch. The main contractor was W. \& J. R. Watson, Ltd, Edinburgh. Thus, for the first time in the history of the Garden, the splendid Herbarium and Library were acconmodated in a building specially designed for use as such.

The new Herbarium and Library (Plate Xrrc) occupies a site just south of the Botany building, now in large measure used for other purposes than botanical teaching and research; the site, in fact, of 
two huts which since the latter years of Bayley Balfour's regime had housed the museum collections, the old Museum having been utilised by Balfour for teaching purposes. The building is $143 \mathrm{ft}$ long and $76 \mathrm{ft}$ wide, the long axis running east-west. It consists of a two-storey block set on top of a smaller ground floor block; there is a lower ground floor of the same size as the upper storeys. This lower ground floor accommodates the administrative offices, curatorial staff, store rooms and a small conference room; the Library is on the ground floor and the Herbarium and Laboratories on the two upper floors. Except for the offices and the store rooms, the building is air-conditioned. It is designed as a framed structure in reinforced concrete with floors and roof of slab construction for economy and speed of erection. The external facing material is entirely prefabricated in standardised units of polished white terrazzo and the podium and terrace are finished in warm grey Heworthburn stone with inset panels of grey vitreous tiles. Windows are sealed double-glazed units fixed into black anodized aluminium window-frames. Suspended acoustic ceilings have been used.

The Library (Plate XII) occupies the whole of the ground floor, a simple rectangular stack providing some $7,500 \mathrm{ft}$ of shelving. There are rows of reading tables along both north and south walls, those along the north being contained in small bays formed by short folio cases. Ancillary accommodation consists of a store on the lower ground floor and a workroom and service desk on the main floor. In the open area at the entrance there are built-in display racks for current periodicals, catalogue cabinets, map table, atlas cases, and reading space. The furnishings are uniform throughout. The bookcases have ends of American walnut which matches the panelling and built-in fixtures. Lighting over the book stack is provided by a suspended illuminated ceiling. The wood-block floor is of Rhodesian teak.

At the present time the Library carries a stock of about 45,000 volumes; two-thirds of these are periodicals of which some 700 titles are taken. For the first time the stock is arranged systematically, the whole Library having been recatalogued by Marguerite Alford and W. H. Brown, ex-Librarians, according to Bliss's classification. Modifications to this scheme have been kept to a minimum but some sections have been rearranged-notably by the use of Bentham and Hooker's numbering in systematic botany, so that the arrangement of the taxonomic books matches that of the Herbarium. 
Along the north side of the first floor a 22-ft strip is cut off from the Herbarium to form the photographer's studio and darkroom, workrooms for the mycologists and the cytologist on the staff, a general laboratory and a culture room. For this part of the building there is an independent air extraction system. The Laboratory (Plate XII) is equipped for all normal routines in mycology, cytology and plant anatomy and provides working space for 6-8 technical staff. ${ }^{\text {I }}$

Though the Herbarium is distributed over two floors its unity is preserved by a central well above which is a raised glass-brick section of roofing with underslung artificial lighting in false beams. It is planned for maximum flexibility with central storage of specimens and peripheral working space. Along the full length of the south side of each floor there is a free consultation bench which is not encroached on for permanent working places for the staff; these are distributed around the other three sides of the top floor and at the two ends of the lower floor.

The Herbarium specimens are housed in specially designed steel cabinets (Plate XII); these are stacked threc high and each contains two ranks of six pigeon-holes. In order to permit a simple magnetic closure each cabinet has a single door the inner flange of which is fitted with rubber containing a magnetized strip. This system gives not only effective dust-proofing but most acceptable silence of operation as well. These cabinets are finished in grey stove-enamel and were made and installed by Roneo, Ltd.

The Herbarium contains one and one-half million specimens. Among the most interesting of the old collections is that of Paul Dietrich Giseke (1745-96), a pupil of Linnacus. His specimens include several from the Garden at Uppsala and two which evidently came from Linnacus's own herbarium and bear his handwriting. Another very valuable collection, which is especially rich in cryptogams, is that of the great Edinburgh botanist, Robert Kaye Greville (I794-I866). And of course there are the enormous collections made by George Forrest in South-West China, the collections which gave new impetus to active taxonomy in Edinburgh from which stemmed the work on Rhododendron, Primula and other Sino-Himalayan groups of plants and which brought international fame to the Royal Botanic Garden. Equally

IJ. A. Ratter was appointed Cytologist in 1960 and R. Watling Mycologist in 1962. 
large and equally important are the more recent collections from South-West Asia, especially P. H. Davis's Turkish collections; the work currently being pursued on the flora of S.W. Asia is bringing further international renown to the Garden.

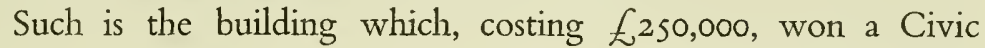
Trust Award in 1966, was widely admired by many of the 3,500 visitors to the Tenth International Botanical Congress in Edinburgh in August 1964, and was officially opened on 29th June 1964 by Her Majesty The Queen. The records of this splendid occasion are a birch tree, planted by The Queen near the south-west corner of the building and, in the Library, a rare volume of paintings of Indian plants by Mrs James Cookson, specially purchased for the Library, and autographed by Her Majesty. Little is known about Mrs Cookson although her paintings show that she was a knowledgeable botanist and a very skilled artist. Thus the volume is not only an object of great beauty but is also of considerable scientific interest and value.

A specially bound copy of the first catalogue of plants grown at Edinburgh, the HORTUS MEDICUS EDINBURGENSIS of James Sutherland (1683), was presented to Her Majesty.

The Queen examined some of the Library's most interesting volumes and several exhibits in the Herbarium. One of the latter illustrated something of the work of George Forrest; others, the travels made by members of the staff in furtherance of present investigations-travels to Turkey, Afghanistan, Pakistan, Burma, Malaya, Sarawak and New Guinea. All the exhibits were illustrated by interesting specimens, photographs, and living plants-for the introduction of new material to cultivation in the Botanic Garden has been an important aim of these expeditions. And all the exhibits showed abundantly well, how, because since the Second World War China and much of the Himalaya have been virtually closed to Western botanists, the research work done at the Garden has been largely directed to these other parts of the world-as well as to Great Britain.

As in the past, so today, the research work in the Herbarium and Laboratory is concerned with one aspect of botanical science, taxonomy, which comprises the naming of plants and their classification, affinities, geographical distribution, etc, and which can only adequately be pursued when one has access to the large collections of dried plants in the Herbarium. These large herbarium collections are essential to any study of the natural resources of a 
particular area, to studies of land potentials, to the evaluation of raw materials possibly suited to man's needs in a multiplicity of activities-forest products, agricultural crops, medicine, industry, for instance. So long as world populations increase and areas of low population density exist man will demand an increasing quantity of biological data on these areas, data which will serve as factors influencing human migrations. Thus plants must always have an economic importance in man's everyday existence and this is not always appreciated.

Also not always appreciated is the importance of a system of precise naming for these plants. Just as the engineer, for instancc, must have precise names for the units he works with, so must the worker with plants. Perhaps the importance of this can best be seen against the background, for instance, of the breakfast table, where the cloth, table, chairs, probably are plant products, and the tea, coffee, cereals, toast, marmalade, certainly are. Just as it is necessary to have names for these plant products so is it necessary to have names-precise names-for the plants from which these products have been derived; for these plants are of international importance and, as such, must be recognised internationally. It is of little use to know that tea is manufactured from some species or other of Camellia. There are approximately Ioo species of Camellia and it is absolutely necessary to know that tea is manufactured only from one of them, Camellia sinensis. The international nature of botanical taxonomy is best appreciated when it is realised that Latin is the universal language used to obtain the necessary precise connotation.

The necessity for this precision, the necessity for a precise name and an accurate identification of every plant-the necessity for plant taxonomy-will be evident from the following example. A species of St John's Wort, which had been identified, rather casually as it happened, as Hypericum perforatum, became a weed of considerable nuisance in the arable parts of New Zealand. As it refused to respond to normal weed eradication measures biological methods of control were tried. It was known that, in Europe, a particular insect did great damage to the flowers of this Hypericum, destroyed the fruits and thus prevented the widespread distribution of the plant by means of seed dispersal. Accordingly, at great expense, the insect was extensively bred in Britain and multitudes were transported to New Zealand. But the insects simply refused to inhabit the flowers of the New Zealand Hypericum which continued to spread all over the country. In desperation, and as a last resource, specimens of the 
pernicious weed were sent to a herbarium for critical study. In the herbarium it was quickly realised that the plant in question was not typical $H$. perforatum at all but a Mediterranean form of this species known as $H$. perforatum variety angustifolium, the flowers of which are also inhabited by an insect. Now when this insect was bred and shipped to New Zealand in huge numbers it did inhabit the New Zealand Hypericum, destroying the fruits, preventing seed dispersal, and thus effectively controlling the spread of the weed. Until this Hypericum became a noxious weed threatening an important part of the country's economy taxonomic work on these plants no doubt would have been regarded by many people as a matter purely of academic interest. But who can say which species of plant may be an even more obnoxious weed tomorrow, or, for that matter, a host for an insect pest or a fungal disease?

The research work of the Garden's scientific staff is published in the Garden's official scientific journal, NOTES FROM THE ROYAL BOTANIC GARDEN, EDINBURGH, which Bayley Balfour founded in I900, as well as in other international scientific journals.

At the official opening of the Herbarium and Library one exhibit on view was of particular interest; it comprised preliminary models and plans of new glasshouses to replace the existing front range of houses which, dating mainly from the early years of this century, were outmoded and in some cases in an unsafe condition. The central house, for instance, was in a hopelessly dilapidated state, and, having been propped up for several years with great wooden struts, was now closed to the public. The preliminary plans showed that the new plant houses were to be quite unique in design, lacking an internal framework and depending for support on an intricate external structure of steel tubes and cable from which the glass would be suspended. Preliminary design studies had shown that a structure of this sort would produce minimum shadow and light interference to the plants within the houses and at the same time afford an architectural result pleasing and well suited to its position in the Garden.

Work on the demolition of the old houses began early in 1965, and the laying of the foundations of the new ones in November of that year. Not until July 1967 did planting begin.

The main house (Plate Xva) is a single structure and, running east to west, is divided into five climatic environments. It is $420 \mathrm{ft}$ long, spans $60 \mathrm{ft}$, is $\mathrm{I} 5 \mathrm{ft}$ high to the eaves, and to the ridge $28 \mathrm{ft}$, except in the large central section where it is $36 \mathrm{ft}$. 
The gain in height in the central environment was made possible by taking advantage of the existing site levels. A second house, of identical construction and running north-south, is $100 \mathrm{ft}$ long and $50 \mathrm{ft}$ wide and links the main range with the Palm Houses. The external supporting side framework consists of diamond-shaped latticed tetrahedrons made up of light tubular members which project upwards above the rafters to twice the height of the eaves. The main tubular members are 3 ins in diameter while the lacing members are solid and $\frac{3}{4}$ in in diameter. Additional support is provided by side and overhead rafters which are of rectangular hollow sections, 6 ins by 3 ins, and which are prevented from sagging by $\frac{1}{4}$ in diameter suspenders which ride over the apex of the side frames. Inter-action between the suspenders and the framework also provides resistance to side sway from the wind.

In the main house a $40 \mathrm{ft}$ span prestressed concrete footbridge is provided to link the east and west environments and at the same time to provide a viewing platform about $9 \mathrm{ft}$ above ground level in the large central section-a platform which allows visitors to see the ground vegetation and layout pattern from above and which ultimately will bring them into intimate contact with the crowns of tall specimens.

The houses are equipped with fully automatic heating and ventilation devices. Among the refinements incorporated in the system is an external rain sensing device which automatically lowers ventilators and so protects plants, as well as visitors. Similarly, a wind-direction sensor overrides the normal opening sequences of the ventilators to lower them during periods of high wind. There is also provision for night temperature 'set-back' to provide a better environment for the plants and by means of which, on frosty nights, the minimum temperature setting in a particular environment within the planthouses can be lowered to save fuel. Ventilation is natural and carried out by side and ridge opening windows in all sections of the house except the Tropical Aquatic one where there are only ridge opening windows. The heating is by high pressure hot water and the heating surfaces are gilled tubular units arranged singly or in banks of two, three or five. In order that pipework inside the houses be limited to the minimum, the lieating units are restricted to the external sides of the houses and are fed by pipework from a perimeter duct carrying the mains. Nerve centres for the heating and ventilation systems, which are 


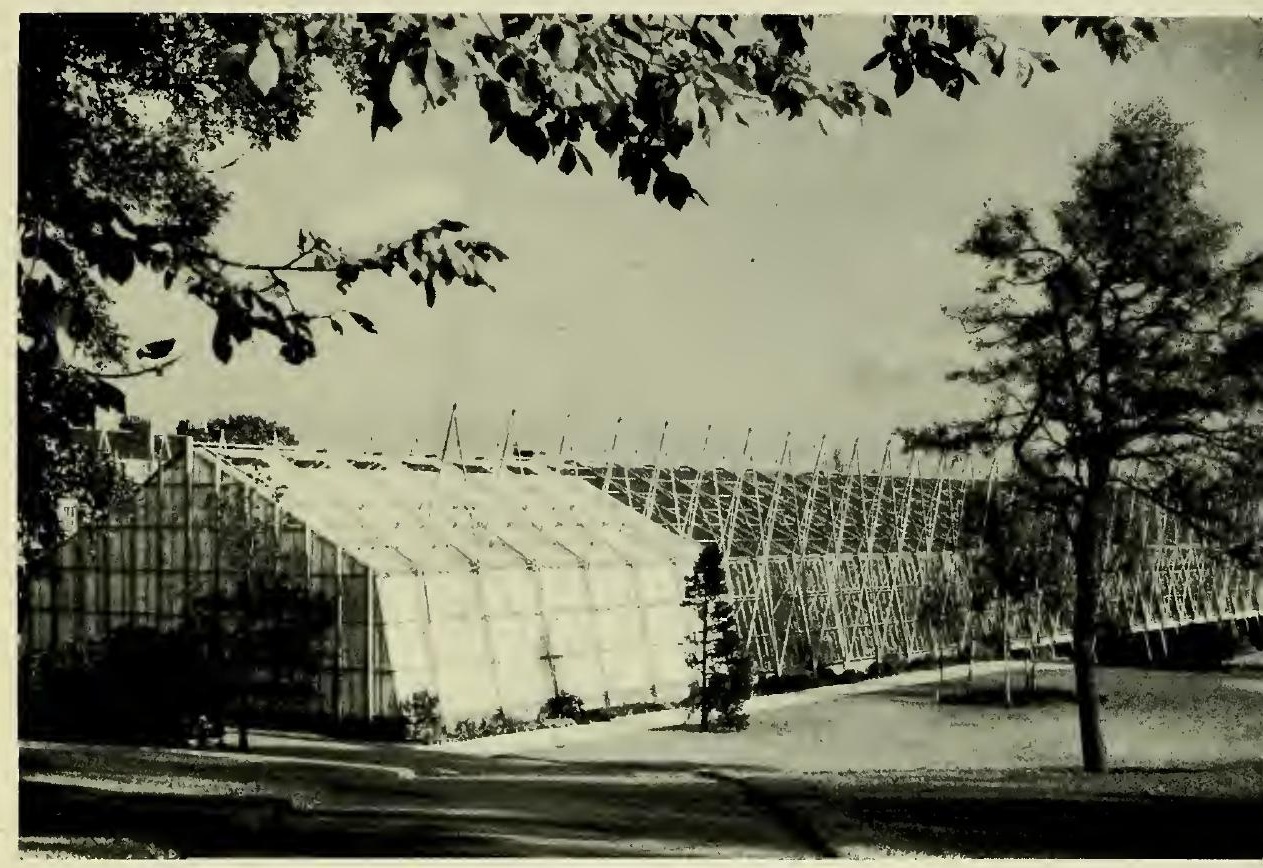

(a) Exhibition Plant Houses, officially opened by Her Royal Highness The Princess Margaret, Countess of Snowdon, 25 October 1967

(b) Giant Victoria Water Lilies

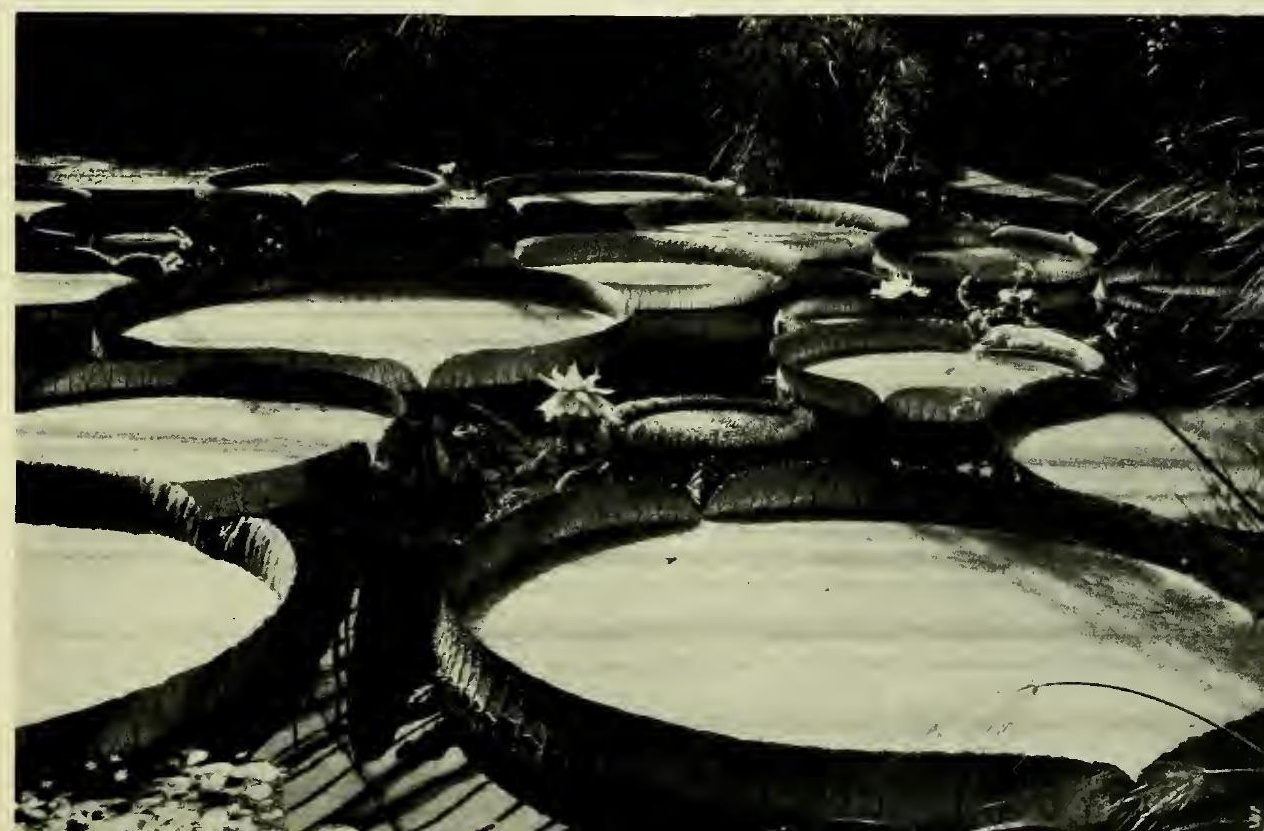




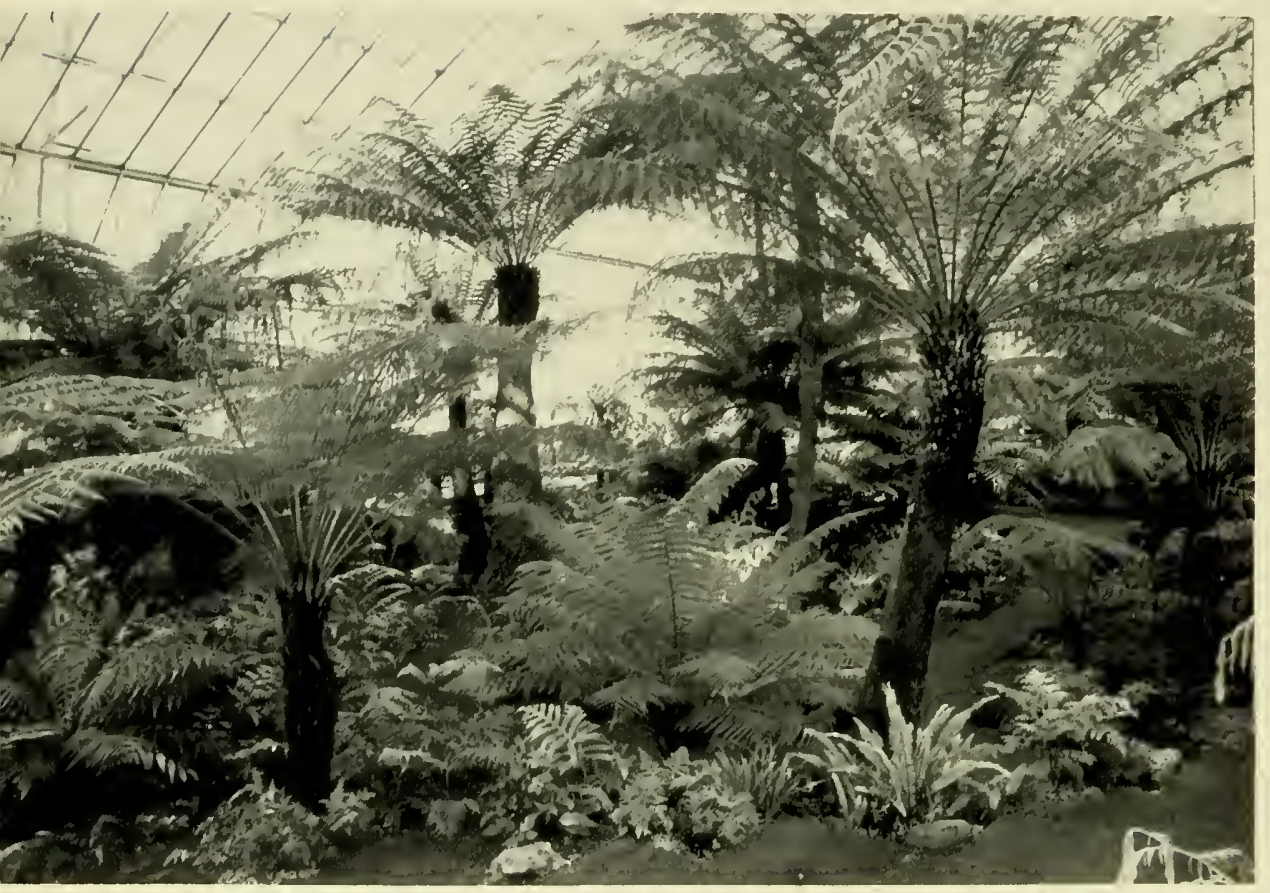

(a) Ferns in the Exhibition Plant Houses

(b) Tree Ferns in the Logan Botanic Garden, Wigtownshire

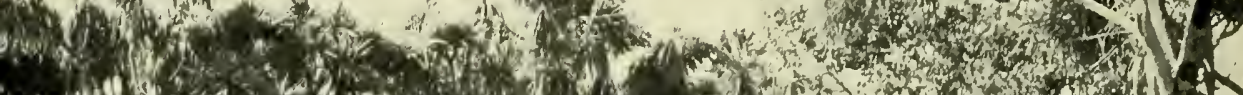

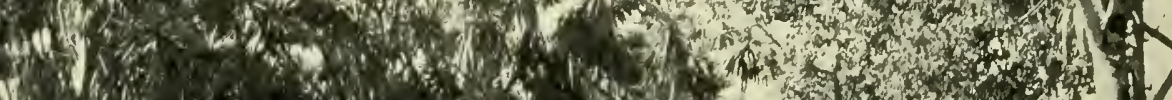

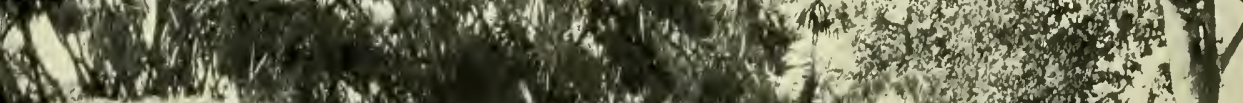

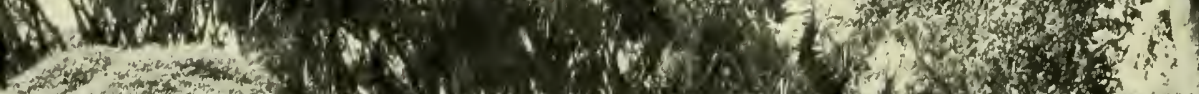

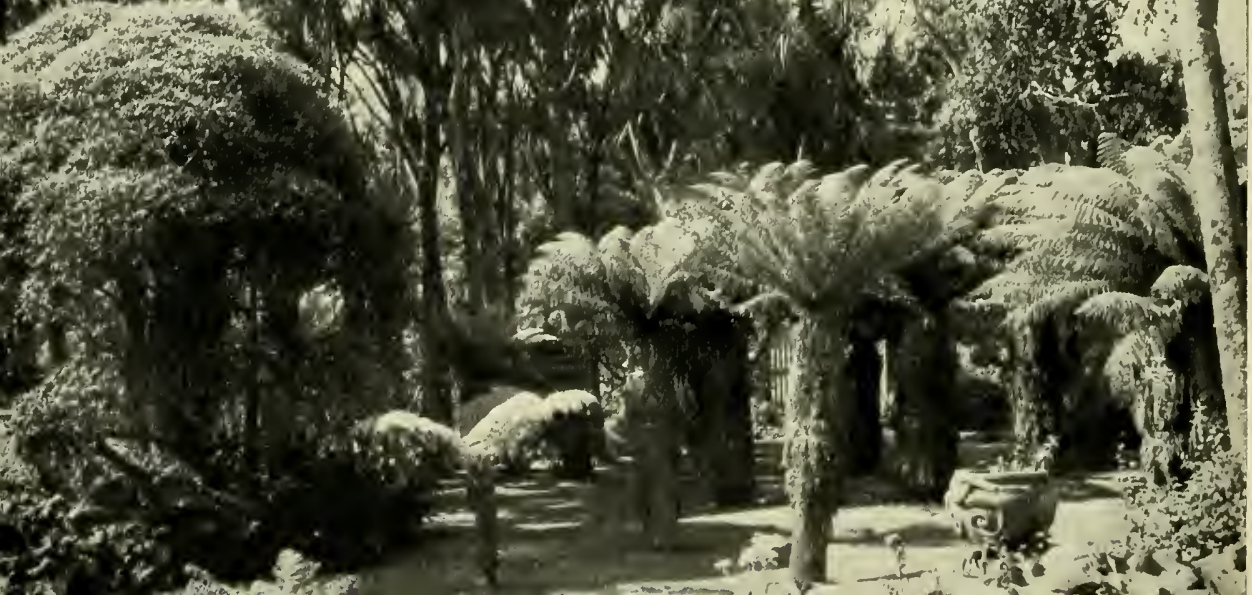


electronically operated, are concentrated in two control rooms; each contains three control panels, one for each environment.

The project was the responsibility of the Ministry of Public Building and Works, Scotland. G. A. H. Pearce was the Architect and was assisted by J. Johnson. L. R. Creasy, J. W. Walley and H. E. Mills were the Structural Engineers and A. D. McDougall, assisted by $\mathrm{T}$. Dowie, the Mechanical and Electrical Engineers. Alexander Hall and Son (Builders) Edinburgh Ltd was the main contractor.

The building of these houses undoubtedly was the most important event in the annals of glasshouse construction since the nineteenth century works of Joseph Paxton and the construction of the Kew Palm House. So far as internal planting and landscaping is concerned, however, the new houses represent a complete break with the past and in achieving a natural type of layout, displaying the plants, wherever possible, with a piece of their own environment, the results have proved not only environmentally satisfactory for the plants but aesthetically satisfying as well.

The landscaping and planting of the houses occupied most of the labour resources of the Garden during the entire year of 1967 . Not since the construction of the range of houses at the turn of the century did a comparable upheaval confront the Curator and his staff. But on this occasion the task was of greater magnitude and required considerable ingenuity to exploit the differences in level of the site in the interests of visual effect and efficient design. The work required a very considerable effort by everyone concerned and it was accomplished without additional labour but merely with some hired equipment and the efficient use of existing plant.

As the contractor completed the concrete walling of the various environments or sections, sandy sub-soil, obtained as a result of regrading operations to the south of the main structure, was transported into them. Though manual labour was considerable it was greatly reduced by hiring a motorised soil elevator with a thirtyfoot boom. The soil was tipped from tractor shovels directly into the improvised cone-shaped hopper, constructed by Garden staff, over the soil conveyor belt, and the infill was deposited almost precisely where it was required in the interiors of the houses. Not until the beginning of July was it possible to begin introducing the top-soil to the houses and laying the paved pathways. The paving, of exposed aggregate concrete, was laid by small work parties of the horticultural students supervised by foremen and so well was 
it handled that it is a major attraction in the houses. Finally, with the opening date just over three months ahead, the first few plant specimens, a group of tall Aloe bainesii, preserved from the old houses, were planted in the east-end Cactus and Succulent section on I3th July. Even then there was only glass in the roof and none at the gable end. In fact some specimens subsequently planted there were so badly tattered by the wind that planting had to be delayed for several weeks until the glazing of this section was completed.

On Ist August one of the giant water lilies, Euryale ferox, was planted in the pool of the Temperate Aquatic House and in the next few days other aquatic species were also set out, including Thalia, Cyperus and Nymphaea. With the subsequent planting of large specimens from the old houses, in the borders surrounding the pool, the house had a very established appearance in a matter of a few weeks. In the meantime the paving of the pathways was proceeding in the next environment, the Temperate House, and on Sunday 24th September a plant of the giant Victoria water lily was carried by six students and the Curator from a temporary pool in the Plant Propagation Department to the newly-completed pool in the Tropical Aquatic House. Although the date for the official opening was now only four weeks distant this plant produced its first flower on that very day. Well-established plants of other aquatics, such as rice and Egyptian Paper Reed, were also placed in the water then, and within a week the planting of the entire house was completed.

As a result of delays in the glazing, planting of the large central Temperate section could not be started until $x 2$ th October, thirteen days before the opening. In the west-end Fern section, by this time, some tree ferns had been planted but until the day before the opening ceremony there was intense activity to have the work completed. No effort was made to plant the new link between the main structures and the Palm Houses; it was thought best to delay the transference of large specimens of Cycas from the Palm House to their new environment until March 1968.

Obviously the erection of a building of such dimensions and architectural merit necessitated considerable reshaping of the surrounding land and precluded any compromise in the landscape treatment of its environs. In the planning of the landscaping activities it was realised that considerable quantities of fertile topsoil would be needed not only for the disturbed areas of the Garden but also for the interiors of the houses: Good top-soil has become 
very difficult to obtain and it was only after a prolonged search"in I966 that a considerable stockpile was located near the site of excavations for ancillary roadworks connected with the Forth Road Bridge. Tests showed that the reaction and composition of the soil was satisfactory, but, since it had been stockpiled for several years in almost anaerobic conditions due to the great depth of the stack and compaction by tracked vehicles, its fertility had been impaired. Some eight hundred tons were obtained merely for the cost of transportation and, in order to restore its fertility, it was spread in a nine-inch deep layer over an area of existing top-soil in the turf nursery at the Garden's Experimental Ground, a ten-acre site near the Garden, for long known as Duncan's Nursery, which the Ministry had acquired from the Fettes Trust in 1958. Here it was aerated by frequent cultivation for two months and then a leafy, vigorous strain of agricultural rye grass was sown upon it to improve the crumb structure. By the time it was required for the borders in the houses and in the open ground, the soil was completely rehabilitated and has given very satisfactory results.

Landscape drawings already had been prepared of a layout which would complement that envisaged for the interiors of the houses and create a setting worthy of such a structure. Reshaping of the entire area up to I 50 yards from the imposing south facade of the building was necessary. Several large deciduous trees, represented elsewhere in the collection, were removed to facilitate the reshaping of the landscape and realignment of roadways to link the new structure with the rest of the Garden for pedestrians and service vehicles alike. Where valuable specimen trees could not be spared and were too large or mature to transplant the land was appropriately undulated in order not to bury the root systems so deeply as to impair their survival.

But much more than extraction and preservation of trees was required. Many large semi-mature specimens from other parts of the Garden were transplanted to the vicinity of the new building to link it with the existing planting. Thus a row of twenty-five-foot tall Leyland Cypresses was transplanted to screen some visual clutter at the east end of the building. A grove of birches with their concomitant ground flora was moved from a Forestry Commission wood in East Lothian and this group now ties the new house very effectively to its setting and gives a feeling of permanence and maturity to the building. In addition, a large Japanese Umbrella Pine and two Scots Pines were successfully transplanted, as were, 
to the rear of the site, many Lombardy poplars and birches, about thirty feet tall. These latter were planted in late summer, when still in leaf, to screen the heterogeneous collection of semidilapidated glasshouses and wooden huts which still formed part of the Plant Propagation Department. All the trees were moved by the Newman tree transplanter the development of which was sponsored by the Civic Trust some years ago. William and James McNab would have approved.

Apart from the rearrangement of the trees it was only by stripping the entire area of walling, paths and other features that suitable land shapes, on a scale acceptable near the new houses, could be created. Previously this part of the Garden landscape had been marred by piece-meal alteration over the years with concomitant diversely angled slopes and numerous small angular areas of lawn the maintenance of which absorbed a disproportionate amount of labour. These reshaping activities were accomplished mainly with the Garden's two agricultural tractors fitted with soil levelling equipment. A fortunate long, dry period of summer weather permitted the use of these implements almost to the total exclusion of manual labour except for the preparation of the grass seed bed. In carrying out the work the fine sandy sub-soil, which had to be excavated over considerable areas to a depth of six feet, was used in the glasshouses to bring the terrain there up to within two feet of the surface ready to receive the top-soil.

By the end of July quietly rolling contoured surfaces had been sown and were already green. By the end of August the slopes around Sutherland's great three hundred year-old Yew were swept gently downward to the paved concourse at the main entrance to the new house. The remainder of the main area in front of the house was sown early in September and although the establishment of young grass at that time of year is precarious in this part of the country, nevertheless, as a result of continued favourable weather the entire area was green by the date of the inauguration of the houses-25th October 1967.

Her Royal Highness The Princess Margaret, Countess of Snowdon, performed the inauguration ceremony and was happy to meet many of those who had played a part in this great enterprise.

In the early hours of the morning of I 5 th January 1968 the new Exhibition Planthouses triumphantly survived a most severe test. Hurricane winds of up to I2O miles per hour swept over parts of Scotland, including Edinburgh and the Botanic Garden. In spite 
of the fears which some had expressed as to the stability of the houses they remained quite unimpaired and only three panes of glass in the main house were broken. Unfortunately, the Garden's most historic specimen, Sutherland's Yew, which had grown in the old Physic Garden at Holyrood, which had been moved to the Garden in Leith Walk and transported to Inverleith in I822, was completely blown out of the ground and had to be destroyed. In all some thirty trees were lost.

The Botanic Garden was not alone in being blessed with fine new buildings during these years. Much earlier than the University authorities anticipated it was found possible to erect a new building for its Department of Botany near the other biological sciences at West Mains Road. Thus the main University Botany Department left the Botanic Garden and, on Ist September 1965, occupied its new premises, which were officially opened on 27 th November by $\mathrm{Mr}$ (Sir in 1967) F. C. Bawden, the Director of Rothamsted Experimental Station, Harpenden. Happily, the University's historic connection with the Garden was not entirely severed for the University Botany Department's Taxonomy Section still continued to occupy premises in the Botany building at Inverleith whose main area was now put at the disposal of various sections of the Department of Agriculture and Fisheries for Scotland. Moreover, in 1968, the Regius Keeper of the Garden was appointed to an Honorary Professorship in the University Department of Botany. 


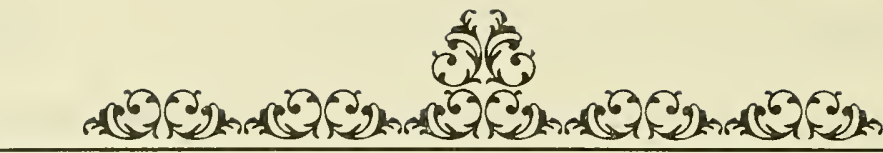

\section{CHAPTER TWENTY}

\section{The Garden in 1970}

ORIGINATING FROM A SMALL PIECE OF LAND 40 FT BY 40 FT at Holyrood in 1670 , the Royal Botanic Garden, Edinburgh, in $1970^{I}$ has to be considered not only from the point of view of the 75 acres (including the Nursery and Experimental Ground) at Inverleith, and the roo-acre Younger Botanic Garden at Benmore, Argyll, but also from the point of view of the famous Garden of Logan in Wigtownshire, the direction of which became the responsibility of the Regius Keeper in 1969.

Logan is most interestingly situated. To the south of the Garden is the Mull of Galloway at the extreme end of the narrow peninsula upon which the Garden lies; a mile to the east is the Bay of Luce; about a mile to the west is the rock-bound coastline and the Irish Sea. Thus the Garden is surrounded by the sea on three sides and as a rule the climate is mild, much more so than in Edinburgh and at Benmore, with a really hard frost rarely occurring. For these reasons many plants from the warm temperate regions of the world can be grown in the open and over the years the Garden became famous for its collection of plants which usually are regarded as so tender in most parts of Britain that they must be given the protection of glasshouses.

Unfortunately, the winters of I96I-62 and I962-63 were desperately severe ones at Logan. In I96I-62, $24^{\circ} \mathrm{F}$ of frost were recorded and, during the first sixty days of 1963 , frost was recorded on forty-eight days. These were the hardest winters for half a century at Logan and, as a result, many tender plants were killed. Moreover during the past twenty years severe gales have seriously damaged the original shelter belts which now have to be renewed. In any

I S. J. Armstrong (trees and shrubs), A. Evans (rock garden and herbaceous plants), A. Snoddy (glasshouse plants), L. Bisset (plant propagation), J. M. Marshall(education) are the Assistant Curators. 
case nothing is less static than a garden and in every garden the time comes when large-scale reconstruction has to be done. Thus it is with Logan now; over the next few years visitors there will see much replanting and will share the excitement of witnessing the partial recreation of a new garden within the framework of the old, under the direct supervision of Martin Colledge a former horticultural student at Edinburgh.

Many years ago the Garden was just an old-fashioned Scottish one in which vegetables, fruits and flowers grew side by side; but, thanks to the unrivalled gardening skill and knowledge and a dedication to beauty on the part of the creators-Kenneth and Douglas McDouall, and later R. O. Hambro-this unique Garden of ornamental plants was created.

Immediately on entering the Garden there is a hint of the almost tropical splendour of parts of the Garden in the shape of a short avenue of the Chusan Palm Trachycarpus fortunei, named after Robert Fortune, the Berwickshire man born in 1812 at Blackadder Town, who trained as a gardener in the Edinburgh Botanic Garden under William McNab before joining the staff of the Royal Horticultural Society in 1840 , who travelled in China and Japan during the years $1843-61$ and who introduced into cultivation in Britain many ornamental plants.

Part of the famous Walled Garden is dominated by the pagan splendour of form of an avenue of the so-called Cabbage Palm Cordyline australis (Plate $\mathrm{xV} n \mathrm{I})$. This plant is one of the main features of Logan (Plate XVIIa); but it is not a palm-it is a member of the lily family; and it is not a native of Australia as the name might imply. It is, in fact, a New Zealand plant and Captain Cook gave it the name Cabbage Palm when first he saw it in 1772 . The avenue was planted in r9I3 when each plant was a couple of feet high. Usually in July great heads of bloom are formed, up to four feet long, creamy-white and fragrant, to be followed by huge bunches of white berries the size of a small pea. The other dominant and infinitely spectacular plant of the Walled Garden, unlike Cordyline australis, is a true native of Australia-the tree fern Dicksonia antarctica (Plate Xvib). Some of the plants are over fifty years old, 8-1o ft tall, and have a diameter of $\mathrm{I} 2 \mathrm{ft}$ or more across the fronds. Normally given the protection of glasshouses in Britain at Logan these tree ferns are so much at home in the open that self-sown sporelings frequently are found in various parts of the Garden. 
Many plants from Chile find the conditions at Logan very much to their liking; the climbing Lapageria, with fleshy pendulous pink or white flowers, named after Josephine de la Pageric, wife of Napoleon and an ardent botanist and gardener; the closely allied Philesia magellanica, in Chile growing in the shade of dense woods and at Logan forming a great low-spreading evergreen shrub in June and July covered with rosy-crimson tubular flowers; Mitraria coccinea, the bright scarlet Mitre Flower; Asteranthera ovata, an evergreen climber also with large red flowers; Jovellana violacea, forming a remarkable hedge and commencing to flower in early May, producing thousands of pale violet or yellowish-white, heavily spotted, calceolaria-like flowers; Crinodendron hookerianum, the Lantern Tree, in June ablaze with red lantern-shaped flowers; the Winter's Bark Drimys winteri, its milk-white flowers with the fragrance of jasmine; three azaras, the small-leaved Azara micropliylla with small vanilla-scented flowers, the narrow-leaved $A$. lanceolata, and the oval-leaved $A$. dentata; Myrtus luma with beautiful cinnamoncoloured stem, white flowers and black sweet fruits; Lardizabala biternata, at the end of the year with two types of flower, drooping clusters of purple male flowers and solitary female flowers; and the close ally of the pineapple, Fascicularia bicolor, the rosettes of narrow spiny leaves turning a glowing red, and surrounding, from July to September, clusters of pale blue flowers.

These southern hemisphere plants give to the Garden at Logan a particular atmosphere which, certainly in Scotland, is quite unique. Even so, plants of the northern hemisphere, especially from the Sino-Himalaya, grow with great abandon. Certain primulas, Primula japonica and P. pulverulenta for instance, seed themselves all over the place in countless thousands, whilst in May the Water Garden is a sheet of blue Meconopsis grandis, M. betonicifolia, and the marvellous hybrid between these two species, M. x sheldonii.

Other, less tall growing species of Meconopsis, such as the yellow $M$. integrifolia and the purple to sky-blue $M$. simplicifolia, find a congenial home in the Peat Garden, a garden of great historical interest, for it was here, on these low terraces built of peat, that the now so popular peat gardening originated. These terraces were constructed by the McDouall brothers especially to grow the brilliant flowered dwarf high-alpine rhododendrons from the Himalaya and Western China which enjoy an open moist situation and all the light and air possible. But apart from rhododendrons the Peat Garden is an ideal place for the cultivation of rare species 


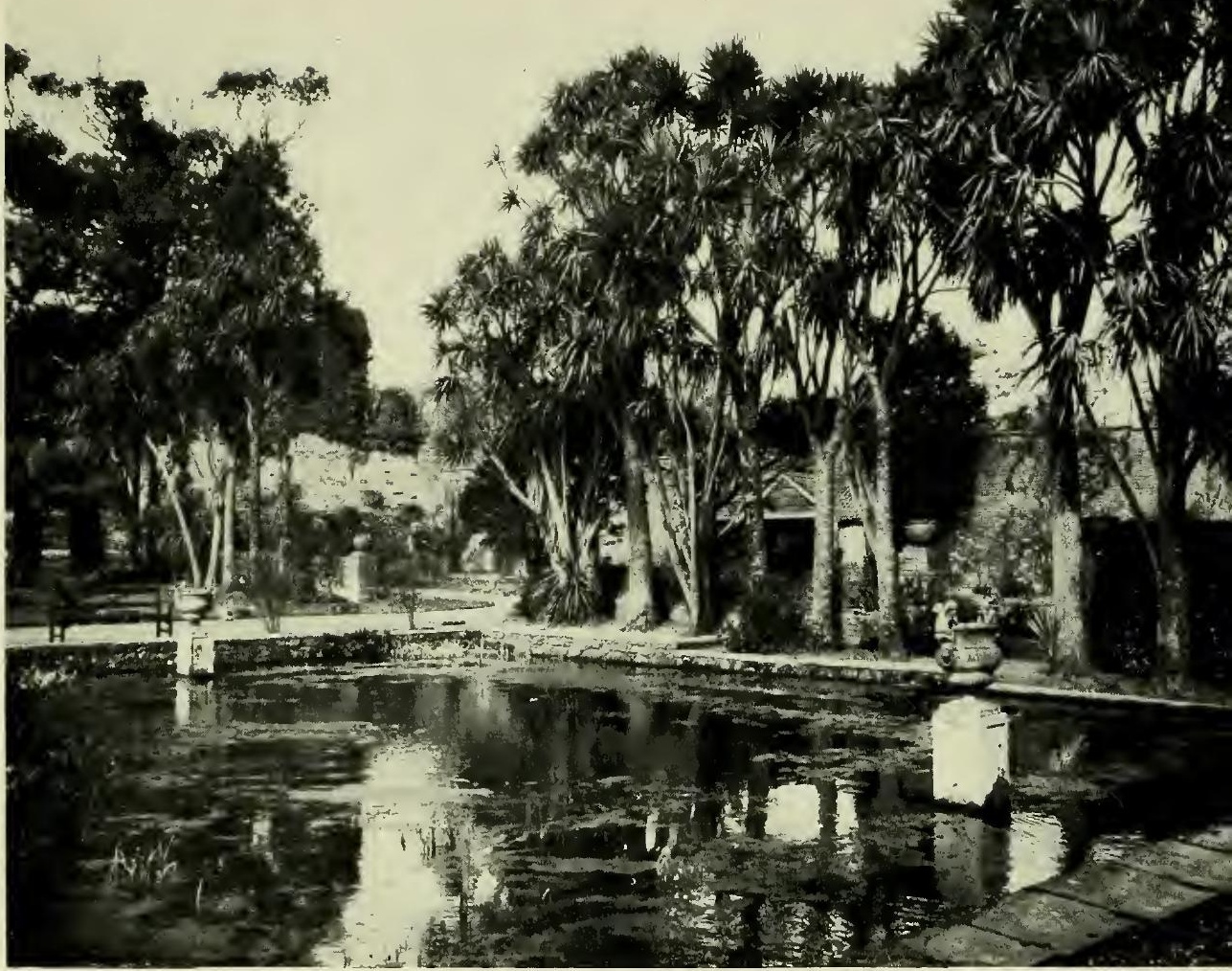

(a) Cabbage Palms in the Logan Botanic Garden, Wigtownshire

(b) Rhododendrons in the Younger Botanic Garden, Benmore, Argyll.

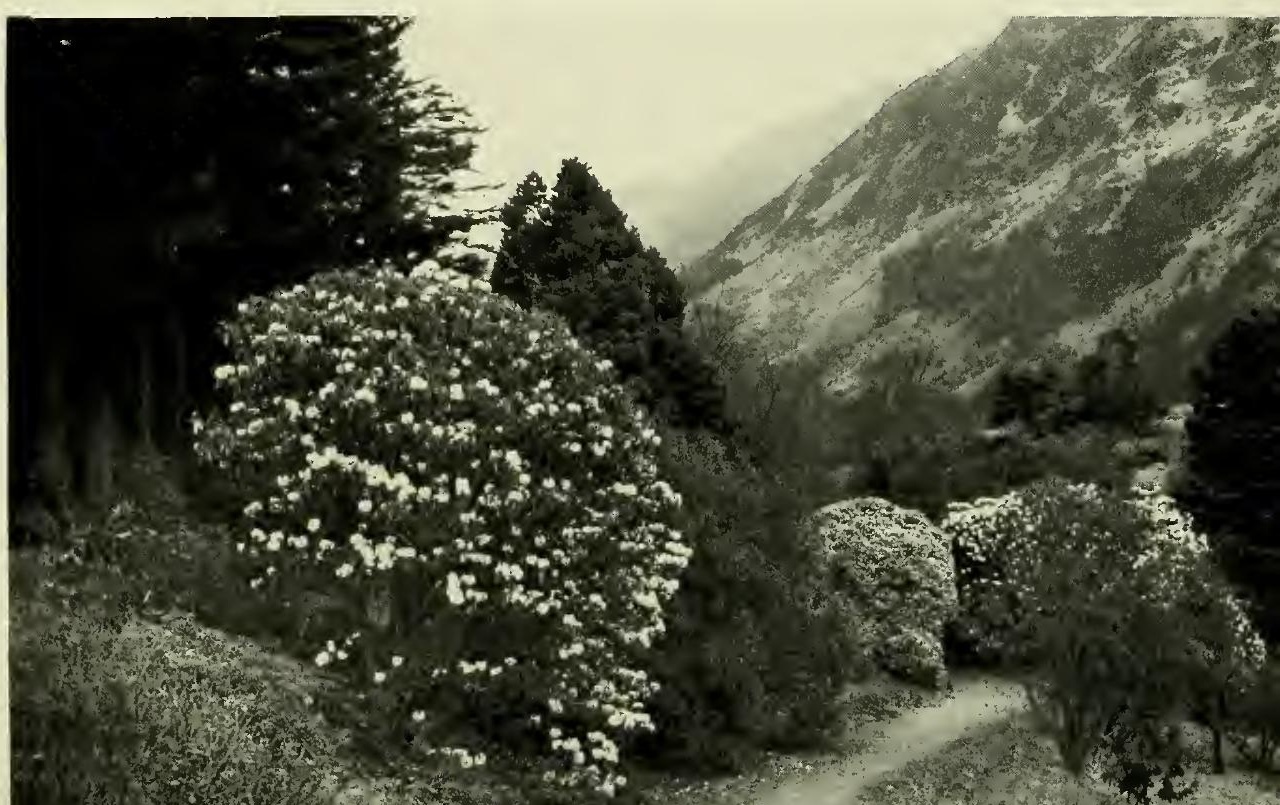


Cabbage Palm Avenue, Logan Botanic Garden

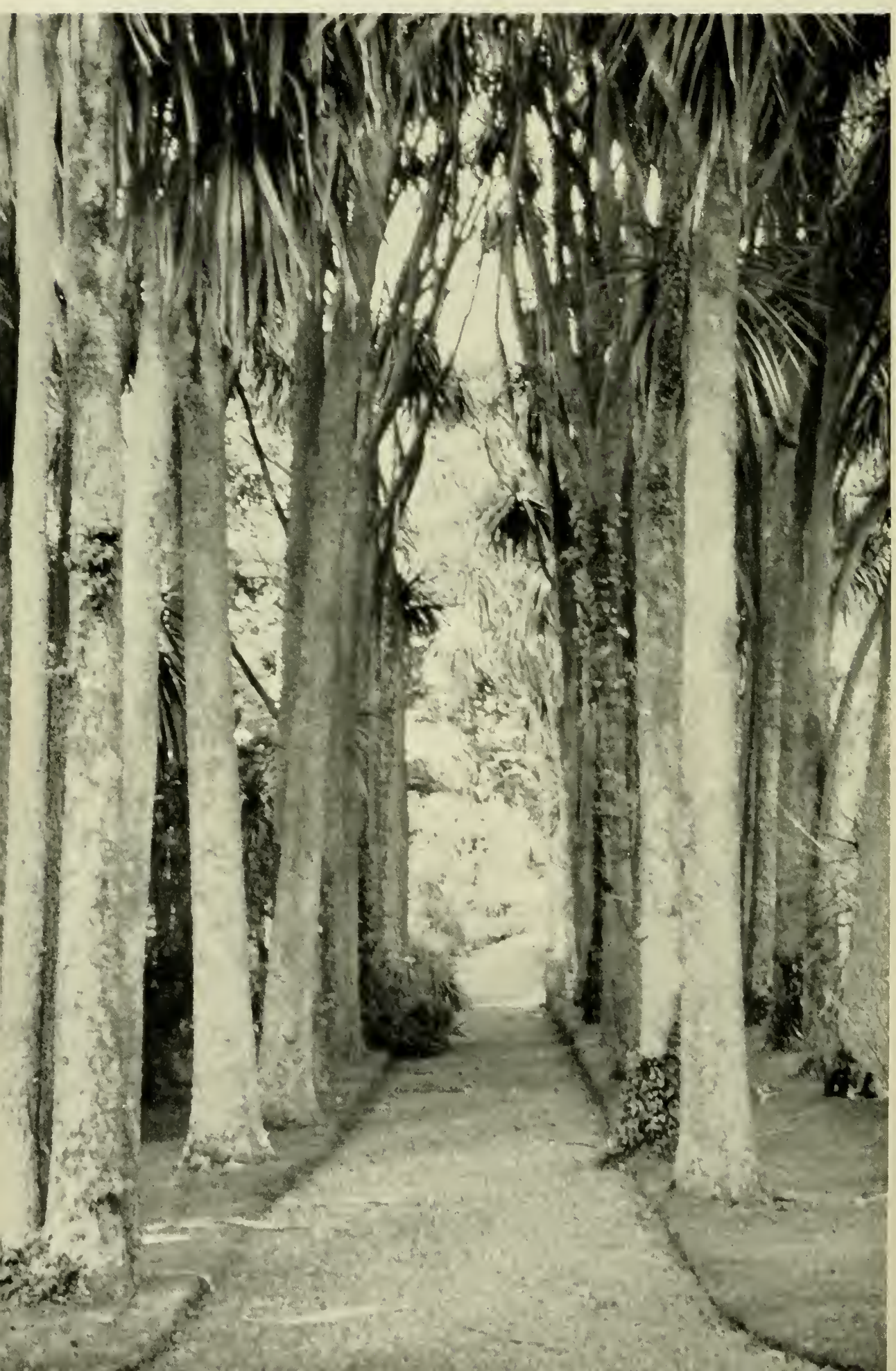


The Woodland Garden, Royal Botanic Garden, Edinburgh

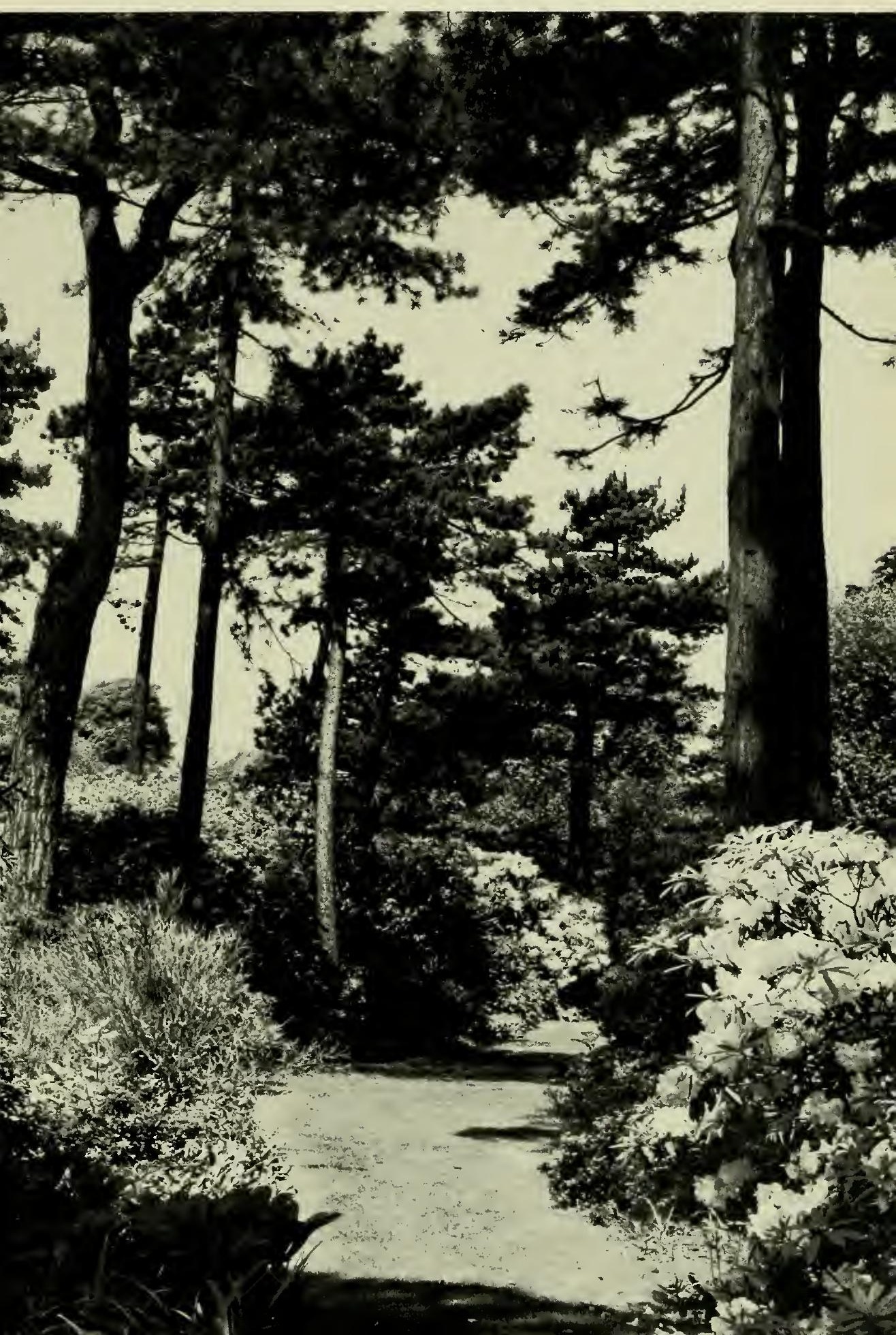


The Avenue at Benmore of the California Big Tree

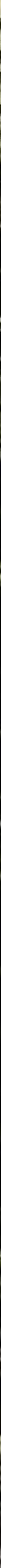


of Primula, Lilinm, Nomocharis, Notholirion and many another plant for the connoisseur. Over the years the Peat Garden had gradually deteriorated and had to be resoiled and replanted in 1964 by Colledge. This historic site is now restored to its former glory and once again, as one distinguished horticulturist wrote years ago, 'all the lilies of the field grow waist deep in seas of dwarf rhododendrons.'

As at Logan, even more so at the Younger Botanic Garden at Benmore; during the next few years visitors there will be able to witness an enormous amount of replanting and literally the recreation of a new Garden, or Arboretum (for Benmore is essentially an Arboretum) within the framework of the old.

The vast majority of the plantings made by $\mathrm{H}$. G. Younger and his predecessors at Benmore, and later by W. Wright Smith, who sent vast quantities of plant material from Edinburgh, had been highly successful. Many of the conifers and the rhododendrons had reached remarkable proportions and, moreover, had naturally regenerated themselves in an astonishing fashion. Never employing a large working staff, the labour force during the years of the Second World War was totally inadequate to maintain the Garden and to prevent the regeneration of Rhododendron ponticum, brambles, and many another invasive shrub. By 1956, the Garden was a jungle, chicfly of brambles and $R$. ponticum which had suppressed the proper growth and development of countless trees and shrubs.

In 1956, Richard Lendrum Shaw, who had been trained at the Royal Horticultural Society's Garden at Wisley, Surrey, and who for a short time had been on the Edinburgh Garden staff, was transferred to Benmore and placed in charge of the small staff. With great dedication, industry and intelligence, Shaw and his colleagues began the immense task of rehabilitating the roo-acre Garden. Each year a section of the Garden was cleared of Rhododendron ponticum and other undesirable shrubs and replanted according to a preconceived plan. Many conifers, propagated in Edinburgh and not previously grown at Bennore, were introduced and many rhododendrons, some of great stature, were moved from various parts of the Garden and planted in the newly rehabilitated areas in accordance with their presumed natural affinitics. This arrangement of the species of rhododendron in their natural groups, or series as the botanist calls them, is one of the features of the Benmore Garden. By I965 the process of rehabilitation was nearing completion, and then Shaw joined the staff of the Royal Botanic 
Gardens at Kew where he was appointed Curator of the Gardens in the following year.

Shaw was succeeded at Benmore by Arthur Hall who had received his horticultural training at the Edinburgh Botanic Garden before gaining further experience in Uganda. By the end of 1967 the Younger Botanic Garden, in its magnificent Argyll setting and dominated by its great conifers, was as exciting and as spectacular a garden to visit as any in Britain.

Tragically, early in the morning of I sth January 1968, gales of hurricane proportions swept over and devastated the Garden. Two people narrowly missed being killed, most of the buildings were severely damaged, the conservatory being completely demolished, and over five hundred conifers, many of them over $100 \mathrm{ft}$ in height, were destroyed. The problems confronting the Garden staff in 1956 were as nothing compared to those which now taxed their courage and skill. The huge task of clearing away the fallen timber, with the support of the Forestry Commission, of rescuing precious plants, of repairing drains and making roads and paths accessible to the public, took many many months, but finally was accomplished in most triumphant fashion. Even so, developments at Benmore were delayed for at least two years. However, in 1970, the Tercentenary year of the Royal Botanic Garden, it is encouraging to realise that its Garden at Benmore is in large measure a young creation which promises well for the future.

Though the rhododendrons (Plate Xvirb) at Benmore provide a great display of colour over several months of the year, are beautiful to see at any time of the year, and are of considerable interest, in that, planted in their various series, visitors may study what has aptly been called a Living Textbook of the Genus Rhododendron, it is really the conifers which are of greatest importance, simply by reason of the fact that they grow not at all well in Edinburgh, but, magnificently, most of them, at Benmore. Edinburgh's average annual rainfall of some 25 ins, and its industrial pollution, prohibit the successful cultivation of most conifers. Only a few species are really tolerant of an impure atmosphere. Pinus nigra, the Black or Austrian Pine, is much more resistant to industrial pollution than is the Scots Pine and forms the backbone to the shelter in several parts of the Edinburgh Garden. Picea ontorika, the Serbian Spruce, known to occur in nature only on the banks of the River Drina in Yugoslavia, certainly succeeds better in the soot and grime than any other spruce and grows fairly well in Edinburgh. 
Cedars also succeed reasonably well, and the Edinburgh plant of the hybrid Leyland Cypress, x Cupressocyparis leylandii, of quickgrowing pyramidal habit, is one of the best in the country. The rest of the conifers, unfortunately, are poor.

But in the clean atmosphere and the annual average 90 ins of rain at Benmore, most conifers-especially those of the Pacific West Coast of America-grow quite splendidly. In spite of the hurricane of 1968 there are magnificent stands of the Douglas Fir Pseudotsuga menziesii, Picea sitchensis the Sitka Spruce, Tsuga heterophylla the Western Hemlock, and Thuja plicata the Western Red Cedar or Arbor-vitae. All of these are over a hundred feet high, one specimen of the Western Hemlock being over I5o ft high and probably the tallest in Britain, and from them all natural regeneration is very prolific. There is an avenue of the Monkey Puzzle Araucaria araucana, showing great variation in leaf size and in stem marking. Abies alba the European Silver Fir and $A$. procera the American Noble Fir quickly grow into splendid trees, whilst the growth of some of the Himalayan and Chinese species, notably $A$. spectabilis the East Himalayan Fir, is very promising. Most remarkable of all, however, is the avenue, some 300 yards long, of the California Big Tree Sequoiadendron giganteum, each plant about $\mathrm{I} 20 \mathrm{ft}$ high and approaching 90 years in age (Plate $\mathrm{xx}$ ).

As at Edinburgh and at Logan, so many of the plants at Benmore recall the names of some of those who have been associated with the Botanic Garden; George Forrest who introduced to cultivation many of the rhododendrons; John Jeffrey, recommended by Hutton Balfour for the Oregon Expedition from Edinburgh of 1850 and the introducer of the Noble Fir, the Douglas Fir, the Sitka Spruce and the Western Hemlock; and Archibald Menzies, a pupil under John Hope in the Leith Walk Garden, who will always be associated with the introduction of the Monkey Puzzle. And high on the Benmore hillside, with a superb view of the Holy Loch, is a shelter erected to the memory of William Wright Smith.

Probably no garden in the northern hemisphere has been more widely influenced by the plant introductions from the SinoHimalaya during the first half of the twentieth century than has the Botanic Garden at Inverleith. Of course, during the last fifty years many gardens have been created consisting almost entirely of rhododendrons and azaleas, but at Edinburgh 'if rhododendrons play the most important role in the display .... they are well supported by a full cast of trees and shrubs, herbaceous and rock 
plants and bulbs, where each member is of established reputation.' $x$

A comparison of the plans of the Garden in 1909 and in 1970 (Plans I and II facing pp. I60 and 216) shows that fundamentally the basic structure of the Garden has changed but little. In the intervening years most trees and shrubs have, of course, markedly increased in size and accommodation has had to be found for large numbers of new trees and shrubs raised from SinoHimalayan seeds and from other sources. Inevitably, the Garden today has a more wooded and mature aspect and for this the rhododendrons are in the main responsible. Although the Garden is by no means a rhododendron garden it is the rhododendrons which gave the Garden its rather unique character.

The story of their introduction to the Garden is interesting. When the Garden was at Leith Walk in I775, only three species were in cultivation; Rhododendron ferrugineum, the so-called Alpine Rose from the Alps of Central Europe, and two North American species, $R$. maximum and $R$. viscosum. Gradually others were introduced: in I8Io $R$. ponticum, a native of Spain and Portugal but more especially of that part of Asia Minor known to the ancients as the Pontus, which makcs a splendid windbreak, will resist frost, and is much used as a stock for grafting other rhododendrons; in I8I4 $R$. caucasicum, from below the snow line on the higher reaches of the Caucasus and N.E. Turkey; by I8I5 $R$. catawbiense, occurring in thousands of acres on the upper slopes of the Southern Alleghanies on the North Carolina border; and in 1820 , from the foothills of the Himalaya and of almost tropical magnificence, the tree-like $R$. arboreum.

Unfortunately, $R$. arboreum with all its splendour brought with it an almost tropical aversion to cold and soon it was evident that, unlike the others, it would be far from hardy over much of Britain. Even so, its introduction marked an era in the annals not only of the rhododendron but of British floriculture; the rearing of this splendid product of nature was the 'herald voice' of all the charms we associate with the rhododendron of today. What could not be accomplished by acclimatization would be achieved by hybridization; the blood of the tough would be mixed with the blood of the tender; and by I 860 there had been fashioned in various parts of Britain, from these original few species, several hybrids which have withstood the test of time and which even today are still almost

I G. C. Taylor in COUNTRY LIFE, 23rd September 1933. 
unbeaten where factors of habit, size of flower and truss, and hardiness are concerned-the double bluish-mauve 'Fastuosum', 'Nobleanum' in scarlet, rich pink and white, 'Lady Eleanor Cathcart', clear pale pink with a reddish blotch-these and more. Examples of these old historic hybrids with their gnarled twisted stems can be seen near the Copse $\left(\mathrm{F}-\mathrm{G}_{3}\right),{ }^{\mathrm{I}}$ in the region of the daffodils on the Hill (D-E 7-8), and in the rhododendron bank which stretches from near the East Gate entrance of the Garden to near the lower Peat Garden.

Such was the position a hundred and twenty years ago. Today it is vastly different thanks to Sir Joseph Hooker who introduced ten other species from the Himalaya in I849-5I; to George Forrest who between 1904 and 1932 introduced large numbers of species from S.E. Tibet and W. China; and to such collectors as Wilson, Farrer, Rock, Kingdon-Ward, Ludlow and Sherriff, who likewise introduced or reintroduced many rhododendrons from the same area. Today it is estimated that over 400 species-plants introduced into cultivation from their native haunts-are in cultivation in Edinburgh and the vast majority of them have cone from W. China, S.E. Tibet and the N.W. Himalaya.

In Edinburgh these many species have not been planted, as at Benmore, in accordance with their natural groupings; they have been planted, due regard being paid to aesthetic effect, where experience has shown they will grow best, and where they form an interesting background and give shelter to a vast assemblage of herbaceous species. The Garden's soil-for the most part alluvial sand, in some places overlying clay and lacking in humus-and Edinburgh's east coast climate-cold easterly winds and, very often, late frosts, an average rainfall of only some 25 inches and a lack of warmth and sunlight-are by no means ideal conditions for rhododendron culture. However, by enriching the soil with peat or leaf mould and by providing the necessary shelter and irrigation, considerable success has attended the efforts to cultivate out of doors all but the more tender species.

They vary enormously in habit; from tiny mat-like growths a couple of inches high, through pygmy undershrubs up to $2 \mathrm{ft}$ and to large shrubs is $\mathrm{ft}$ or more high and even to tall trees. It is obvious, therefore, that they cannot all be grown in one part of the Garden. Thus it is necessary to visit the Rock Garden (H-I9--Io)

I The letter and figure references are to the grid squares of the map-Plan $\Pi^{\prime}$ facing p.28o. 
and Peat Garden (F-G8-9) to study the dwarf low-growing species; and the Woodland Garden (G-H9-Io), the Copse $\left(\mathrm{E}-\mathrm{F}_{3}\right)$, the Rhododendron Walk (C-F4-6) and the Azalea Lawn (G-H4-5) to study the medium and large-sized species.

When a site for a woodland garden can be chosen in a glade traversed by a winding stream or upon the wooded rocky slopes of a hillside, nature has laid a good foundation for the gardener to work upon. When, however, such a garden has to be evolved in the less promising environment of a town the difficulties are much greater. In Edinburgh the illusion of remoteness from the artificial atmosphere of the town is rendered possible by introducing bold masses of evergreen shrubs, mostly rhododendrons, which serve to shut off the surrounding buildings, whilst trees are spaced to provide partial overhead shade. The Woodland Garden (G-H9-1o) is not merely a place for growing such plants as may be too rampant elsewhere; it offers scope for a characteristic and pleasing form of landscape gardening. Winding paths, grassy or strewn with pine needles, wander through the woodland, and at almost every turn a new prospect unexpectedly opens. Evergreen shrubs-above all the rhododendrons-provide a leafy background and masses of colour in their season, and with these the many herbaceous plants combine to produce a series of pictures each complete in itself.

We know, of course, that the area of the present Woodland Garden (Plate XIX) has for long been devoted to the growing of conifers-cypresses, thujas, firs and pines. Unfortunately, none is of great size, none is a beautiful specimen, and none will ever be satisfactorily cultivated in Edinburgh's soot-laden atmosphere. Nevertheless they serve their purpose in providing an appropriate amount of shade and shelter for the woodland vegetation in general. Protection from wind at ground level is provided chiefly by the evergreen rhododendrons which also form a setting for the smaller growing plants, especially herbaceous plants, and from an aesthetic point of view provide interest in winter when these have died down. As in a natural woodland many of the herbaceous plants forming the ground vegetation are bulbous or tuberous containing in their underground organs reserves of food which enable them to flower early in the year before the deciduous trees have broken into leaf.

The abundance of rhododendrons in the Woodland Garden should not blind one to the presence of other shrubs. There are hydrangeas, viburnums, eucryphias, camellias, magnolias, coton- 
easters, and many others. Neither should the shrubs divert one's attention from the woodland floor and from the plants which revel in shade and thus make excellent ground cover. One of the most striking is the May Lily Maianthemum kamtschaticum, whose slender rhizome quickly colonizes the ground so that in the deepest shade pairs of heart-shaped leaves appear in the spring together with slender racemes of small white flowers. The Wood Anemone Anemone nemorosa, which is a British native, is another gregarious herb of deciduous woodlands, spreading by means of its slender rootstock. This plant varies greatly in size, structure and colour of flower, and in time of flowering. There are several forms in the Woodland including the well known 'Robinsoniana' with large lavender-blue flowers.

Horticulturally there is at the present time great interest in ground cover plants especially for shady situations. Visitors interested in such plants can learn a great deal from a careful study of the ground vegetation in the Woodland. There is the yellowflowered Greater Celandine Chelidonium majus; two species of Corydalis, the purple-flowered C. solida of N.W. Asia and Europe, and C. cava of C. and S. Europe in both its typical purple form as well as in its white-flowered form albiflora; the N. American Bleeding Heart or Dutchman's Breeches Dicentra formosa, with pink or dull red flowers; several species and hybrids of Bergenia, close ally of the saxifrage, with their large thick glossy leaves and massive inflorescences of reddish or pinkish flowers; many species and hybrids of Hosta, the Plantain Lily of Japan, with their beautiful, often variegated, foliage and racemes of white to dull lilac rather tubular flowers; these and many more herbaceous plants.

Situated on a knoll overlooking the Palm Houses, the Copse $\left(\mathrm{E}-\mathrm{F}_{3}\right)$ is protected by shelter belts of holly and of Swiss Stone Pine, Pinus cembra, and its development from a copse of deciduous trees has been progressing since the early I930's. As with the Woodland, the exploitation of the area was motivated by the scarcity in the Garden of suitably sheltered areas for the growth of the new introductions of rhododendron, magnolia, meconopsis, lily and many other plants of unknown potential. Shortly after I950 the Copse was reconstructed; beds and borders were widened to accommodate herbaceous plants, broad grass paths were laid, spreading beeches which cast far too much shade were removed, and pines, mainly Scots Pine Pinus sylvestris, and Corsican Pine P. nigra var. calabrica, were planted to improve plant association and to provide more 
light in summer and more shelter and insulation from frost in winter.

Though rhododendrons form the main fabric of the Copse, there is a wealt 2 of other flowering shrubs and trees in this section of the Garden. There is a collection of viburnums which extend beyond the Copse on to the grassy slope at G3. There is a collection of magnolias including those precocious kinds which open their flowers before the leaves have appeared, as well as those which produce their flowers and leaves at the same time. Unfortunately, the precocious kinds, including Magnolia campbellii from Sikkim, its sub-species mollicomata from S.E. Tibet and W. China, and the Chinese $M$. sprengeri, which are among the most magnificent of flowering trees and shrubs, are liable to be damaged by spring frosts and usually are not very satisfactory plants in Edinburgh. Much more rewarding is the group of species which display their flowers and leaves at more or less the same time, usually in June. One of the best of these is $M$. sieboldii, of Japan and Korea, which carries white cup-shaped scented flowers each with a central boss of ruby-red stamens. Quick to attain tree proportions is the Japanese $M$. obovata, whose large creamy-white flowers are conspicuous in June not only on account of their size but also because of their heavy perfume which, on a still evening, is discernible at a distance of many yards.

The Rhododendron Walk $\left(\mathrm{C}-\mathrm{F}_{4}-6\right)$ extends from the West Gate entrance to the Garden (A6) and encompasses the Gallery of Modern Art. Although the borders on each side of the Walk mainly contain rhododendrons, these plants provide settings and sheltered situations for many herbaceous species; species of Paeonia, Hosta, Bergenia, Meconopsis, Lilium, Primula. Formerly, when the Gallery of Modern Art was the residence of the Regius Keeper, this was a somewhat isolated part of the Garden. However, since I957 redesigning of the entire area has attempted to link it to the rest of the Garden and even beyond the precincts of the Garden, by means of a series of vistas. For example a long vista, flanked by fastigiate forms of commonly grown trees, draws the eye to the vivid summer colours of the Annual Borders (D2); another, framed by a pair of graceful pendulous birches, affords a pleasing view of the Copse; whilst a third, facing south, utilizes Edinburgh Castle as its focal point. Apart from typical rock garden plants, and heathers, representatives from almost every other part of the Garden are to be found in the Rhododendron Walk which, therefore, in large measure, represents the Garden in microcosm. The rhododendrons, and the other shrubs and trees, both deci- 
PLAN III/ROYAL BOTANIC GARDEN EDINBURGH 1970

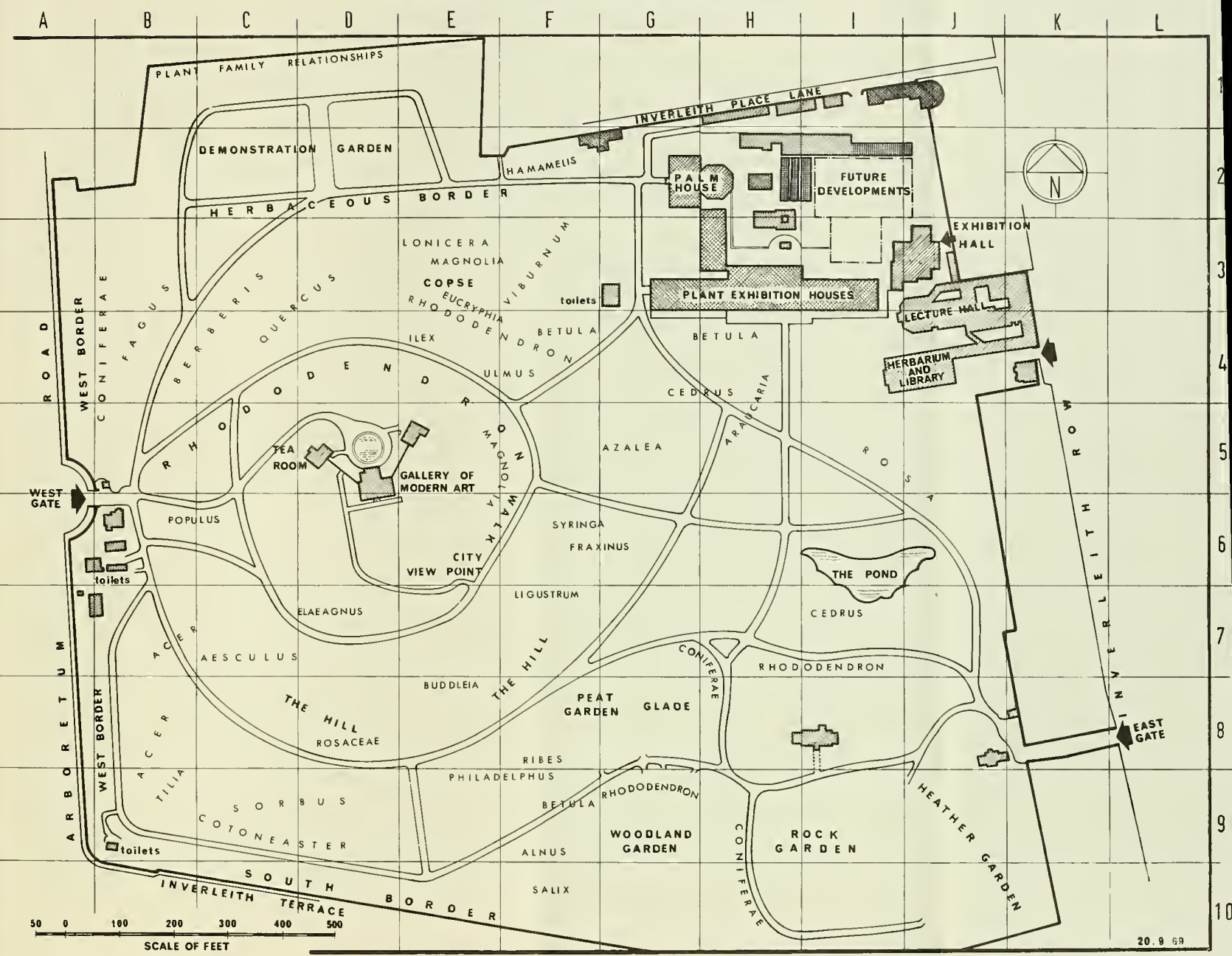



duous and evergreen, in the Arboretum (B-F7-9; B-J4-6), form the main structural elements in the layout of the Garden and give the Garden its particular seasonal character. Originally, it was intended that, as far as was convenient, all the species of a single genus would be assembled as near together as possible, and in fact much of the original planting was done on this basis, as may be seen on Plan IIr. Over the years, however, owing to the continuous introduction of new plants from many parts of the world, especially from the Sino-Himalaya and from N. America, and because certain trees and shrubs irrespective of their relationships have had to be used for shelter, it has not been possible to adhere strictly to this plan. Thus, while concentrations of species of certain large genera such as the oaks (Quercus), the birches (Betula) and the ornamental crab apples (Malus) can be found on particular lawns, it should not be assumed that the entire tree and shrub representation of a genus is in a particular area.

For instance, the main collection of oaks (Quercus) is on the lawn to the north of the Gallery of Modern Art $\left(C-D_{3}-4\right)$, but fine specimens of Quercus dentata, Q. farnetto and Q. lusitanica can be found at J6, $\mathrm{H}_{7}$ and $\mathrm{I}_{5}$ respectively. Near the Pond (I-J6-7) there are specimens of chestnut, although the main chestnut (Aesculus) collection is on the southern slopes of the Hill $\left(\mathrm{C}_{7}-8\right)$. Even so, members of certain genera and families are conveniently close to each other. The lawns (B-F8-9) on either side of the main walk extending from the West Gate eastwards contain a varied collection of trees of the rose family (Rosaceae) such as the flowering crabs and rowans (Malus and Sorbus), hawthorns (Crataegus), and of the maple family (Aceraceae) and the lime family (Tiliaceae). East of these lawns (F9-1o) will be found willows (Salix) and poplars (Populus), both members of the Salicaceae, and silver birches (Betula) and alders (Alnus) of the family Betulaceae. An extensive and interesting collection of barberries (Berberis) is principally on the lawn (C-D $3-4)$ between the conifers and the main collection of oaks.

The collections of trees and shrubs provide much of interest and of beauty at all times of the year and are worthy of study in every season. And they are by no means confined to the Arboretum, the Woodland, the Copse and the Rhododendron Walk. They form a most important element of the Rock Garden (H-J9-IO)-probably the most widely known and appreciated feature of the entire Garden.

By present-day standards and tastes the Rock Garden is by no means a beautiful construction and although in recent years certain 
changes and improvements have been made-notably the addition of the water course with its miniature waterfalls and pools-there is still a very great deal too much rock and not enough soil for the successful cultivation of many plants. Even so most plants in the Rock Garden grow remarkably well thanks to good drainage, a fairly moist atmosphere and very few extremes of temperature in summer and in winter; they grow so well in fact that the casual visitor is not conscious of a surplus of rock for much of it is covered by prostrate and creeping shrubs as well as by mats of herbaceous plants. For this purpose several members of the family Leguminosae are invaluable. There are certain species of broom for instance: Cytisus ardoinii from the Maritime Alps, a decumbent shrub 4-8 inches high and, in April and May, a sheet of golden-yellow flowers; a hybrid of this species with the white Spanish broom C. albus, known as C. $\mathrm{x}$ kewensis, with flowers of creamy-yellow; Cytisus hirsutus var. demissus, or $C$. demissus from the sun-baked cliffs of Mount Olympus and thus needing all the warmth it can get but perfectly hardy in all but the most exposed situation and prolific in the production of its large yellow and rich brown flowers. There are several genistas: Genista hispanica the Spanish gorse, one of the most brilliant of garden shrubs when covered with golden-yellow flowers; another Spanish gorse, the spiny G. horrida, of value in that it flowers from July to September; G. lydia from S.E. Europe and the East Mediterranean; and G. pilosa, which, with a wide distribution in S. Europe, is also a native plant of S.W. England.

Members of the rose family, Rosaceae, also serve this same purpose of carpeting the rocks. There are many species of Cotoneaster from the Himalaya, S.E. Tibet and W. China, all of which provide an abundance of decorative fruits, and the deciduous species fine colour in the autumn before the leaves are shed. There are many kinds of Potentilla, especially the many forms of Potentilla fruticosa wide ranging in the northern hemisphere and a native British plant in Teesdale, the Lake District and Western Ireland. And there are several prostrate conifers, especially junipers, forms of Juniperus sabina, J. squamata and J. horizontalis. All these, and many others, help to hide great boulders of rock which otherwise would be somewhat offensive to the eye.

The conifers in the Rock Garden are of especial merit. In a Rock Garden of so vast a size clearly it is of importance to have plants of interest and of beauty during the entire year. There is no problem. during the spring, summer and autumn seasons; at these times 
there are far too many fine plants, in flower or in fruit, to be studied by the visitor even during continued visits. In the winter, however, it is all very different; bulbous plants are dormant under the ground; herbaceous plants have died back; deciduous shrubs present only naked stems. But the dwarf evergreen conifers are of great interest and beauty. Study the diversity in their shape; prostrate carpets, low round cushions, umbrella shapes, pyramids broad and narrow, compact cones, small fastigiate columns. Study the diversity in colour; every shade of green, glaucous-grey and blue, bronze, silver or gold or green splotched with these colours, colours which are rather intensified during the winter months.

As elsewhere in the Garden, so in the Rock Garden (Plate XIva, b), rhododendrons, this time the dwarf kinds, are invaluable plants. Most of them evergreen, in nature they favour an open situation and find the conditions in the Rock Garden greatly to their liking. Again, they vary greatly in habit, from a carpeting creeping species no more than an inch high such as Rhododendron imperator, to specimens $3 \mathrm{ft}$ or more tall. One group of rhododendrons is particularly well represented-the so-called Lapponicum Series. All members of this series are high altitude plants, most of them from Western China where they form a low matted growth over hundreds of miles of alpine moorland, producing in May, as Captain Kingdon-Ward wrote, 'a chromatic storm-tossed surfrose, pink, purple, lavender, and amber, through which one may wade ankle-deep for days on end .... the term "Lapponicum Sea" is not inappropriate for this rainbow ocean of blossom.' Nor is the term inappropriate to describe the Edinburgh Rock Garden during the months of May and June, although there are, of course, rhododendrons belonging to other series in flower from January until September or October.

Thus the shrubs are of tremendous importance in the Rock Garden. They give it stability, they break the uniformity of the contours, they cover unsightly rock and they provide an appropriate setting and shelter for the cultivation of herbaceous plants from all parts of the world. Indeed it is doubtful if there can be seen elsewhere such a vast representation of the world's herbaceous and shrub flora within the confines of a similar area; plants from Europe, India, China, Japan, Australia, New Zealand and North and South America growing happily together in the open air. Here is excellent proof that many species, which in their native habitats grow under conditions very different to those pertaining in Edinburgh, under 
cultivation and with the minimum of competition which good cultivation can ensure, can be grown very successfully. There is a collection of mainly Scottish alpine plants in the centre of the Rock Garden; there are saxifrages, campanulas, alliums, gentians from Europe, America, Asia Minor, the Himalayas, China, Turkestan; Cistus, Colchicum, Galanthus mostly from the Mediterranean region; Narcissus from Spain, Portugal and North Africa; Trillium, Lewisia, Penstemon, Iris, Erythronium, Dodecatheon, Phlox from North America; Bolax from South America; primulas, mostly of the auricula type, from the Alps of Europe as well as others from the Himalaya; many plants with white flowers from New Zealand, including the celmisias with silvery, often sword-shaped leaves, and great daisylike flowers, Ranunculus lyallii, probably the most beautiful buttercup in the world, and Gentiana saxosa.

To discuss in any detail the plants in the Rock Garden would be merely to catalogue their names, and, instead of perusing a long plant list interested visitors to the Rock Garden doubtless will prefer to make discoveries for themselves, noticing as they do so the great variation in plant form; the succulent habit in Sedum and Sempervivum; the rosette habit in the European Ramonda, primulas, and the New Zealand celmisias; the cushion habit in Silene, Dianthus, Bolax, Acantholimon; the carpet habit of the acaenas of New Zealand and the creeping species of Veronica or Hebe; the whip-cord habit with small leaves closely appressed to the stem in other species of Hebe such as $H$. armstrongii and $H$. cupressoides.

Many shrubby and herbaceous alpine plants find the environment of the Rock Garden rather too dry and warm, and the soil conditions not sufficiently acid, for their successful development. Such plants are much more happily accommodated in the Peat Garden (H8-9) which is in two parts separated by a small area of woodland through which there are interconnecting paths. The peat used consists of irregularly shaped turves cut from the top layer of a deposit, open and spongy in texture and light brown in colour. It is derived mainly from Bog Cotton Eriophorum vaginatum, a little Deer Grass Scirpus caespitosus, some Sphagnum moss and a trace of Calluna, the heather. The reaction is from $\mathrm{pH} 3.5$ to 3.8 rising to just over $\mathrm{pH} 4$ after a few years.

There is so great a wealth of plants in the Peat Garden that in this brief account it is possible merely to indicate the range. The majority of the shrubs are dwarf rhododendrons of creeping mat-forming habit which readily ramify into the peat turves and 
thus stabilize the terracing. Other suitable plants for this purpose are Arcterica nana from N.E. Asia and the Japanese Gaultheria miqueliana which makes an important contribution in autumn and winter with its decorative pinky-white fruits. The red-fruited Gaultheria procumbens from $\mathrm{N}$. America is also an invaluable creeping shrub with great appeal in autumn and winter for fruit and foliage alike, and the white-fruited G. cuneata from W. China is also outstanding among dwarf berrying shrubs. The plants par excellence for clothing the peat turves, however, are the schizocodons and the related shortias. The large leaves of Schizocodon soldanelloides var. magnus become attractively tinted with crimson and bronze during autumn and winter but the main attraction of the plant is the one-inch wide, curiously fringed, rose and white spring flower. Notable among the shortias is Shortia galacifolia characterised by pinkishwhite flowers and long stalked leaves which also become attractively tinted in winter. The most handsome of them all is probably Shortia uniflora with usually pale pink flowers and the magnificent form of it, grandiflora, which has larger flowers more freely produced.

Among the other dwarf shrubs which provide winter ground cover and thus limit the extent to which frost penetrates into the ground, the most prominent are Phyllodoce and Cassiope, while a slightly taller element is provided by Menziesia, Leucothoe and Pieris. Growing among all these shrubs there is a great variety of other plants many of them by no means common in cultivation. There is, for example, Selaginella helvetica distributed from C. Europe to Japan and thus one of the two European representatives of this mainly tropical genus; and the fern, the native Adder's Tongue, Ophioglossum vulgatum, which flourishes here along with the more showy flowering plants. Of the great numbers of these mention must be made of the dwarf lilies, especially the yellowflowered Lilium oxypetaltum and L. mackliniae with attractive nodding rosy-pink flowers, and of the terrestrial orchids which have responded well to this environment. Apart from some groups of native orchids, the two which attract most attention are Dactylorhiza elata from N. Africa, and the Madeiran D. maderensis. Primulas of the Petiolarid group, notably Primula whitei and $P$. gracilipes, make their first important contribution in spring and attract so much attention that the turf in the vicinity of the main groups is often worn bare by visitors. Shortly after these, the Wood Lilies, Trillium, are characteristic of the scene and find here the summer moisture they require. The commonly cultivated and more robust species such as 
Trillium grandiflorum are mainly planted among taller shrubs in the Woodland Garden and elsewhere, but the less common, such as the diminutive, slender-stalked $T$. rivale and the reddish-purple $T$. sessile find an appropriate niche in the Peat Garden. The ourisias, which have an interesting geographic distribution from Tasmania and New Zealand to Andean and Antarctic S. America, also carpet the ground between the shrubs and find in the soil adequate surface moisture for their needs, as do some of the dwarfer meconopsis species, notably the yellow-flowered Meconopsis villosa whose leaves are an added attraction, and the very slender stemmed, fragile $M$. chelidonifolia.

Such, then, are those particular parts of the Botanic Garden which give to the Garden, as a whole, its particular character or individuality. However, there are many who believe that in one other regard the Edinburgh Garden is different from the vast majority of other Botanic Gardens; the endeavours which are made to introduce to the visiting public the enthralling world of plant knowledge.

It was specifically from this point of view that the Demonstration Garden (B-Er) was established in 196r. For many years the Garden Nursery, this part of the Garden was given over to demonstration purposes when the Io-acre site of the former Duncan's Nursery to the north of Inverleith Place was purchased in 1958 and planted as a Nursery and Experimental Ground. Now the Demonstration Garden attempts to illustrate such botanical matters as the different types of pollination, of fruit and seed dispersal, the relationships of some plant families, as well as certain horticultural mattersthe development in cultivation of certain groups of flowers, suitable hedge and ground cover plants, for instance. The exhibits of a botanical nature are of value to all interested in botanical science, especially at school level standard, and are, in fact, frequently studied by visiting school parties, whilst those of a horticultural nature are of interest to all who have an appreciation of plants, and, in their season, are immensely appreciated by the public.

As in the traditional museum, so in this open-air museum, for this is what the Demonstration Garden essentially is, the educational value of the exhibits depends on their adequate documentation. This is done by the use of labels, 8 in by $s$ in, on stands $3 \mathrm{ft} \mathrm{high}$. Up to 400 words of text can be contained on these labels, as can black and white illustrations. The label-text is typed on a 'D. S. J. Varityper' machine, which produces both roman and italic 
type. The typescript is then enlarged on a Xerox I358 machine and printed xerographically on to special aluminium sheets. These sheets are then stuck on to the label stands and coated with a clear lacquer for aluminium and so made watertight. During the winter the labels are taken indoors and are cleaned and revarnished.

These exhibits, and others, are meant for those who have practically no knowledge of botany. But many visitors to the Garden are already students of botany and are anxious to learn more about plant evolution and the relationships of plants. For such visitors especially, but naturally also for the information of all the public, there is a display of plant family relationships in the Demonstration Garden. Even if they were known the interrelationships of all families could never be shown by arrangement in the Garden for they are multidimensional. How inadequate, then, must be a display restricted to a small number of families of hardy plants, most of them herbaceous. This has to be remembered in studying these Plant Family beds. Most of the families are arranged in half-beds facing one another, so that visitors walk through the families rather than round them.

The buttercup and magnolia families, Ranunculaceae and Magnoliaceae respectively, deemed relatively primitive, are at the east end of the Demonstration Garden and the families regarded as most advanced are at the west end. But the area in between is not to be thought of as representing the course of evolution. What visitors see is simply an arrangement of families in such a pattern that various interesting comparisons and contrasts are made easy of examination. For instance, Caryophyllaceae the pink family, and Primulaceae the primula family, can be viewed within a yard or two of one another. Though the flowers of the former have their petals quite free from one another and the petals of the flowers of the latter are joined together, not a few botanists think the two families are closely related. The witch hazel family, Hamamelidaceae, is sited within a few steps of both the rose family Rosaceae and the catkin-bearing plants, two groups which, by some, it is thought to link. Hydrangeas and viburnums are close enough for the resemblances between them to be emphasised.

A balanced view of evolution in the plant kingdom is only obtained by seeing both real relationships and parallelisms. The families are here arranged not only to bring out such possible relationships as those just mentioned, but also to show up parallelisms in structural organization which are certainly not due 
to close kinship. The scabious family, Dipsacaceae, which usually has its flowers in heads, is in close juxtaposition to the daisy family, Compositae, which always does so; but the differences between the two families are so great that their relationships cannot be very close.

Another comparison worth making is that between the orchids, Orchidaceae, in the great group of plants which have but one seed leaf, the monocotyledons, and the balsams, Impatiens, in the dicotyledons. There is a superficial resemblance in their complex floral form and the flowers of both are frequently upside down or resupinate. It is also intrinsically interesting to note that both have reached a high degree of specialisation although both have free petals. Elsewhere, advanced floral structure is nearly always correlated with union of the petals into a gamopetalous corolla.

The visitor who is primarily a gardener or horticulturist and not particularly interested in botany, finds much to absorb his attention in the exhibits of the best plants to use for hedge and ground cover purposes, especially in the Edinburgh area; of the large variety of grasses which can be successfully used for so many purposes and in so many environments; of poisonous and irritant plants; of culinary or sweet herbs; and of the development in cultivation from the parental species, of the modern gladiolus, garden pansy and viola, garden antirrhinum, and autumn-flowering chrysanthemum.

Just as the Demonstration Garden attempts to inform the public on certain aspects of the life of plants which can be grown out of doors, so does the Soundguide Tour of the new glasshouse complex seek to make the public more aware of the plants and landscapes of certain parts of the world-the deserts of Africa and America, the tropics, and the temperate areas of Australasia, for instance. Thus, in house No. I, which contains cacti and other succulent plants, the plants and the Soundguide convey to visitors a general impression of the vegetation of the dry areas of the world-the deserts and semi-deserts of Southern Africa and the other arid areas northwards to the Sahara and from there to the Canary Islands, as well as those of North and South America. By grouping the plants in this geographical fashion a very striking phenomenon is illustrated-the remarkable parallel development in response to arid climate of plants which are widely separated in space and very distantly related botanically.

The adjacent house No. 2 contains warm temperate plants, mainly marsh and aquatic species, and the pool is dominated by 
specimens of the Indian Lotus, Nelumbo nucifera, and its relatives. Such plants, and the water lilies proper, Nymphaea, die down in the late autumn but they produce large tubers which are retained in a dry condition during winter. The marsh plants in this house do not die down, however, and accordingly provide interest throughout the whole year. The well-known so-called Water Hyacinth, Eichhornia crassipes, is a prominent member of the pool. This plant has special air-filled tissues in the leaf stalks with which it is kept afloat. It is native to sub-tropical America but has become widespread in the warmer parts of the world and achieved notoriety through hindering navigation in rivers and waterways by fouling the propellers of ships.

Among the land plants in this house is an outstanding tree-like plant, the Frangipani, Plumeria, a native of Central America and Mexico, with deliciously scented flowers. It has been widely planted in the vicinity of temples in tropical oriental countries. Also represented is the weil-known African Sycamore Fig, Ficus sycomorus, which had an important place in the gardens of Ancient Egypt, producing, as it did, timber, shade and edible fruit. Dominating a considerable part of the African continent from Egypt to South Africa it was much venerated by these ancient peoples.

As the Soundguide explains, the dominant species in the large central section (house No. 3), which is planted geographically, are trees from various temperate regions of the world which are not quite hardy out of doors in Britain. Thus many familiar Australasian trees are here. Among the dwarfer woody plants and the herbaceous species are also representatives of the Australian and New Zealand floras, but of the world's flora perhaps that of Southern Africa is best represented in this house.

The scene in house No. 4 (Plate xvb), which contains tropical aquatic plants, is normally dominated by the giant Victoria water lily. These plants are of annual duration but in the warm water and moist heat in this environment they develop very quickly. Usually the large edible seeds, which are known as Water Maize in their native Amazon region, are sown at the beginning of March and the seedlings are planted in the pool towards the end of April. The leaf structure of Victoria is, of course, one of nature's wonders, but the interest lies in the veins of the leaf which are not really visible from above. Accordingly, below the pool, an underground viewing chamber enables these remarkable leaves to be seen from below. Also in this chamber are other aquatic plants which 
hitherto have never been grown in the Botanic Garden for lack of suitable accommodation.

House No. 5 (Plate Xvia) is the last in the main structure and contains ferns and other plants. The most striking are the tree ferns, the giants of this great group of plants. There are just over three hundred species of these and they inhabit mainly the cooler elevations within the tropics where clouds impinge upon mountains and saturate them with mist to produce the so-called 'Weeping Woods'. Some of them have spread outwards from the tropics, for example to the mild oceanic climate of New Zealand where several species occur. Because of the elevations at which they mainly grow within the tropics, they do not require tropical temperatures and the minimum temperature in the Fern House in winter is $50^{\circ} \mathrm{F}$.

Planthouse No. 6 contains mainly collections of orchids and of cycads-both groups of outstanding botanical interest. The cycads are the most primitive of surviving seed-producing plants. They are related to the ferns on the one hand and to the conifers on the other. The development of their fern-like leaves recalls the ferns, but, like the conifers, they produce true seeds. The ferns, on the other hand, do not produce true seeds, but spores. Their link with the ferns is further exemplified by the female eggs being fertilized not by means of a pollen-tube as in the conifers but by motile sperms as in the ferns.

One of the main botanical interests in orchids is the tremendous variation in the shape of the flowers. These different shapes are no idle fantasies of nature. They have a definite purpose. In many orchids the flower of each species is designed for pollination by one kind of insect. The bait which attracts them is usually nectar and the signposts to it are colour and scent. The scent is usually vanillalike; the vanilla of commerce used to be an orchid and the flavouring essence derived from the ripe fruits. Today vanilla flavouring is largely produced synthetically.

It was Charles Darwin who first studied the pollination of orchid flowers. The flower is of very precise construction. Effortless waste to secure pollination is absent. Only a single stamen remains which produces agglomerations of pollen in a position where the appropriate insect will carry it to the next flower. Each orchid flower, then, in shape, in scent and in colour, in time of flowering, attracts just one kind of insect. It is only when artificial cross-breeding is practised in horticulture that nature's system, which prevents promiscuity in the field, breaks down. 
Planthouse No. 6 forms a link between the new glasshouse complex and the historic old Palm House group which will always be associated with the names of Professor Robert Graham, Professor John Hutton Balfour and William and James McNab. Without a doubt they, and all those who have played their part in the making of the Royal Botanic Garden, would have approved of the efforts being made, by quickening observation with knowledge, to help all those who visit the Garden to savour the full beauty of the living plant world. No doubt also they would be approving of the scientific research work being undertaken on a scale greater than ever before, of the instruction which still is provided to students in horticulture, of the advice which is given, on request, on botanical and horticultural matters, to the general public. And one likes to believe that they would agree with the judgement of Sir Arthur Hill, one time Director of the Royal Botanic Gardens at Kew, when, at the Twenty-fifth Anniversary Celebrations of the Missouri Botanical Garden in I9I4, he said: "With its fine collections of living plants, its herbarium, library, laboratories, ... . the Edinburgh institution may well serve as an example of the ideal Botanic Garden'.

For eighty years, from Ist April I889, the Garden was under the aegis of the Ministry of Public Building and Works (in I889 the Commissioners of Works and Public Buildings). However, as from Ist April 1969, as a result of a transfer of certain Government functions in Scotland to the Secretary of State, Departmental responsibility for the Garden passed to the Department of Agriculture and Fisheries for Scotland. While acknowledging with deep appreciation the long and harmonious association with the Ministry, the Regius Keeper and his colleagues welcomed the new association of Scotland's National Botanic Garden with the Scottish Office. This establishes the closest possible link with Scottish Departments having a direct interest and involvement in the educational, research and practical aspects of botany and horticulture ${ }^{1}$ and provides an appropriate official Scottish context for the continuation of the work of the Garden, recognised throughout the world as a major benefit to plant science.

\footnotetext{
I Towards this end the Exhibition Hall, built with funds generously provided by an anonymous benefactor, is to be officially opened on 2 June I970, on the occasion of the Garden's Tercentenary.
} 


\title{
(3)
}

\section{Appendix}

Text of the 1876 agreement between the Town Council of the City of Edinburgh, the Commissioners of HM Works and the Fettes' Trustees and Carl H. Rocheid, Esq. regarding the purchase of the Lands of Inverleith for an extension of the Botanic Garden.

\section{AGREEMENT}

\section{BETWEEN TOWN-COUNCIL OF EDINBURGH}

AND THE COMMISSIONERS OF HER MAJESTY'S WORKS, \&C.

\author{
AND FETTES' TRUSTEES AND MR ROCHEID
}

\author{
8th, 9th, and I5th May I877
}

\section{The llparties bereto - viz. The Loro Provoss,} Magistrates, and Town-Council of the City of Edinburgh, of the first part (hereinafter called the first parties); The Commissioners of Her Majesty's WORKs and Public Buildings, of the second part (hereinafter called the second parties); and Frederick Pitman, EsQ, ws, as authorised by and on behalf of the Trustees of the late SIR William Fettes, Baronet, and by and on behalf of Charles Henry Alexander Frederick Camillo Everhard James John RoCHEID, ESQ, of Inverleith, of the third part (hereinafter called the third parties): CONSIDERING that the first parties have been empowered by the 'Edinburgh Improvement Act, 1876,' to acquire, for the purposes of the said Act, for the formation of an Arboretum, Public Park, and Pleasure-Ground, and to enter upon, take, and use, for such purposes the lands and property at Inverleith, including Inverleith House, delineated on the Plans and described in the Books of Reference referred to in said Act, or certain portions thereof, lying in the Parish of St Cuthbert's, and County, and County of the City and Royal Burgh of Edinburgh: FurTHER CONSIDERING that the first parties have also entered into an agreement with the third parties as to the extent of the ground so to be acquired, and the rate of Feu-duty to be paid therefor, and as to the conditions and obligations to be inserted in the Feu-Charter to be granted by the said third parties: FURTHER Consmering that the first parties have also, with the concurrence of the second parties, taken powers 
or made agreements to acquire, in addition to the lands delineated on the Parliamentary Plan, certain lands lying immediately to the westward of those delineated in the Parliamentary Plan, and which are described in the heads of Conditional Agreement with the Proprietors of the lands hereinafter referred to; and that the first parties have also obtained powers or entered into agreements to transfer the lands and property so acquired, or the use of the same, to the second parties, for the purpose of the same being enclosed, improved, laid out, ornamented, and maintained as an Arboretum for extending the scientific instruction given to Students attending the University of Edinburgh, and others, in the Royal Botanic Garden, and to lay the same open, under suitable regulations, for the recreation and enjoyment of the Public, and for other objects of public utility: Therefore the parties hereto agree and declare as follows:

First. The first parties shall transfer to, and execute whatever deeds may be necessary for vesting in the second parties all right to the said lands and property at Inverleith, which they have or shall acquire thereto, for the purposes foresaid, and subject to all burdens and obligations whatsoever binding on the first parties in relation to the said lands and property, constituted by agreement with the former proprietors or otherwise, and without prejudice to such generality, subject to the conditions and obligations contained in the document, entituled, 'Heads of Conditional Agreement 'between the Right Honourable the Lord Provost, on behalf of the 'Promoters of 'The Edinburgh Improvement Bill, I876,' on the first part, 'and Frederick Pitman, ESQ, $\mathrm{WS}$, on behalf of the Trustees of the late 'Sir William Fettes, Baronet, and Carl F. Rocheid, ESQ, of Inverleith, on 'the second part,' and bearing date the IIth and I3th days of May I876,a printed copy of which Agreement and relative Plan are annexed, and signed with reference hereto, as the said conditions and obligations shall be expressed in the Feut-Charters of said lands and property at Inverleith, to be granted, with consent of the first parties, in favour of the second parties, the one by the Trustees of Sir William Fettes, Baronet, and the other by $\mathrm{Mr}$ Rocheid of Inverleith, or his commissioner.

Second. That the first parties shall make payment to the Trustees of Sir William Fettes of the redemption price of the feu-duty stipulated by the feu-charter to be granted by them, amounting to the sum of $f_{18} 8,406$, with interest thereon at the rate of five per cent from and after the term of Whitsunday I877 until payment; and the second parties shall make payment to said Trustees of the sum of $f_{3,000}$ as the redemption price of the remainder of said feu-duty.

Third. That the second parties shall further make payment to Mr Rocheid of Inverleith of the sum of $f_{1}, 926$ as the redemption price of the feu-duty stipulated to be paid under the feu-charter to be granted by him or his commissioner as aforesaid, with interest as aforesaid.

Fourth. The second and third parties agree that the first parties shall be, as they are hereby, released from all obligations connected with the said lands and property. 
Fifth. The second parties hereby agree to accept of the said lands and property at Inverleith, and undertake to enclose and fence in such way as the second parties shall consider suitable, in conformity always with the terms of the said Heads of Conditional Agreement, and as to be set forth in said feu-charters, and also conform to plans subscribed by the parties hereto with reference to these presents, and to hold, lay out, and maintain, in a suitable manner, the said whole lands and property as an Arboretum, for extending the scientific instruction given to Students attending the University of Edinburgh, and others, in the Royal Botanic Garden, and as a Park and Pleasure-Ground for public recreation, and for other purposes of public utility, and for no other purpose whatever; but always in conformity with the Parks Regulations Act, 1872 , and Schedule first thereto annexed.

Sixth. The third parties shall provide proper accesses, by good roads or avenues, to and from the said Arboretum, Park, and Pleasure-Ground, and land; and, in particular, ( $\mathrm{I}$ ) They shall give access to the said grounds by the private avenue leading from St Bernard's Row to Inverleith House, but declaring that they shall have right to resume possession of the said private avenue last mentioned, if that is found necessary, for altering, widening, and improving the same, the second parties having, however, continuous right of access for the public by said avenue when and as so altered and improved. (2.) In the event of Inverleith Terrace being continued from Inverleith Row westward, by Sir William Fettes' Trustees, or their successors, or their feuars, or others deriving right from them, the said second parties shall have right of access for the public thereby to the said Public Park and Pleasure-Ground, but the second parties shall not be bound to pay any portion of the expense of forming or maintaining said road leading from Inverleith Row westward. (3.) The third parties shall be bound, and hereby undertake, to make a road, marked on the said plan with the letters A A A, leading northward in continuation of said private avenue until it joins the road from Inverleith Place to Fettes College, said road marked A A A being formed to the satisfaction of the Edinburgh Road Trust; and the said first parties, or the Road Trustees of the City of Edinburgh, being bound to maintain the said road after it is so formed.

Seventh. The second parties shall be entitled to enter upon the possession of the said lands and property, with entry as at the term of Whitsunday I877, notwithstanding the date hereof, and shall thereafter proceed to fence and enclose the said ground, in conformity with said plans, as soon as the third parties shall put the ground into such a state as will admit of the said fences being erected; and thereafter the second parties shall, with all convenient expedition, proceed to lay out the said grounds for the purposes foresaid, so as the said ground may be ready for the Arboretum, and the Pleasure-Grounds may be completed for the purposes foresaid, within two years from the last date hereof.

Eighth. The second parties shall not erect any building or buildings on any part of the said lands, excepting such as may be suitable and necessary for or in connection with the said Arboretum and Park and Pleasure-Ground. 
Ninth. In case any dispute or difference of opinion shall arise under these presents, such dispute or difference shall be referred to the decision of Robert Horn, Esq., Advocate, Dean of Faculty, whose award shall be final.IN WITNESS WHEREOF, these presents, consisting of this and the two preceding pages of print, with this testing clause, which is written by Charles Thomson, clerk to Donald Beith, Writer to the Signet, Edinburgh, are subscribed in triplicate by the parties hereto as follows,-viz., by Sir James Falshaw, Baronet, Lord Provost, and William Skinner, Esquire, Town-Clerk, in name of and by authority of the remanent members of Council present in Council of the City of Edinburgh, both at Edinburgh, on the eighth day of May Eighteen hundred and seventy-seven, before these witnesses, Thomas Clark and David William Walker, both clerks to the said William Skinner; by the said Frederick Pitman, at Edinburgh, on the ninth day of the said lastmentioned month and year, before these witnesses, Alexander Hill Cooper, Writer to the Signet, Edinburgh, and Alexander Mossman, clerk to the said Frederick Pitman; and by the Right Honourable Gerard Noel, First Commissioner of Her Majesty's Works and Public Buildings, at Whitehall Place, London, on the fifteenth day of the said last-mentioned month and year, before these witnesses, Algeron Bertram Mitford, secretary, and Henry Russell Potter, clerk, both of Her Majesty's Board of Works, London.

\author{
JAMES FALSHAW, Lord Provost \\ WM. SKINNER, Town-Clerk \\ FREDERICK PITMAN \\ GERARD NOEL
}

Thos. Clark, witness

D. W. WALKER, witness

Alex. H. CoOper, witness

Alex. Mossman, witness

A. B. MitFord, witness

H. R. POTTER, witness 
Note: The names of plants included in the index are confined to significant discoveries or introductions into Scotland associated with the flora of Scotland and the Royal Botanic Garden

\section{A}

Aberconway, Lord, 242

Abies amabilis, $\mathrm{I} 37$

Abies lowiana, $\mathrm{I} 37$

Abies procera, $\mathrm{I} 37$

Adam, Robert Moyes, 223, 252

Agriculture and Fisheries for Scotland,

Department of,

assumes responsibility

for Garden, 29I

Agriculture, Board of, plant pathology laboratory established, 240

Aiton, William Townsend, 48, 80, 89, 92

Ajuga pyramidalis, 62

Alcock, Mrs N. L., 240

Alexander, Richard Chandler afterwards Prior, $\mathrm{II} 3$

Alford, Marguerite, 259

Alopecurus alpinus, 77

Alston, Charles, Regius Keeper, 37

appointed King's Botanist and

Professor of Botany, 38

study at Leiden, 39

Secretary, Royal College of

Physicians, 39

appointed to the University Chair, 40 publications, 42, 43

Alstonia, 44

Amnals of Botany founded by Bayley

Balfour, I99
Anthony, John, 236

Araucaria araucana, 67

Araucaria araucana avenue at Benmore,

275

Araucarioxylon found in Craigleith

Quarry, I59

Arboretum in Botanic Garden

established, I8I

Dickson's dispute over its opening, I 86 described, $28 \mathrm{I}$

Arbutus andracline, 84

Arctous alpinus, 95

Armstrong, S. J., 270

Arnot, Hugo

his description of the Leith Walk garden, 64

Arthur, William, Regius Keeper, I8, 20

Asperula odorata, 60

Asplenium septentrionale, 10

Asplenium viride, 95

Astragalus alpinus, I II, I9I

Ayrton, Rt. Hon. A. J., I2O

B

Babington, Charles Cardale, 176

Baird, Principal George H., IOI

Balfour, Sir Andrew, 3-10

Balfour, Sir Isaac Bayley, Regius

Keeper

original member of Scottish Alpine

Botanical Club, I23 
quoted on his father, $\mathrm{I} 28$

candidate for Hutton Balfour's Chair in 1879,183

quoted on Sadler, 190

quoted on Alexander Dickson, 193

succeeds Dickson, I95

expedition to Rodriguez, $\mathbf{1 9 6}$

elected to Chair of Botany, Glasgow, I97

expedition to Socotra, 197

publications, 197, 228

appointed Sherardian Professor of

Botany, Oxford, 198

founds Annals of Botany, 199

work in Edinburgh, 212, 232

Honours, 228

retires to Haslemere, 229

Prain's judgment on, 230

Bower's judgment on, 231

recommends Wright Smith as his

successor, 232

Memorial Garden begun, 239

Balfour, John Hutton, Regius Keeper

founds Botanical Society, I I 3

original member Scottish Alpine

Botanical"Club, I23

succeeds Graham, I25

President of the Royal Medical

Society, I 28

work and teaching methods, 128

Professor of Botany, Glasgow, 129

Secretary, Royal Society of Edinburgh, I3O

his excursions, I3 I, I33

procures new class-rooms and

museum, I42

procures new Palm House, I43

negotiates the acquisition of

Inverleith House, I 78

last annual report, 182

Banks, Sir Joseph, 48, 65

his correspondence with Rutherford, 80

foundation of Royal Horticultural

Society, 92

his travels and work for Kew, 92

Barry, Martin, II4

Bartsia alpina, 77
'Battle o' Glen Tilt', I34

Bauhin, Caspar

classification used in the Trinity

Garden, 8

Bawden, Sir F. C., 269

Beattie, Professor, 96

Bee's Nurseries, 226

Begonia socotrana, 197

Bell, William, I4S

Benmore, see Younger Botanic Garden

Bennett, A. W., I98

Bentham, George, I72

Beta naritima, 50

Betula nana, 62

Bews, John William, 224

Bignonia unguis-cati, 70

Bisset, L., 270

Blair, Patrick, 4 I

Bobart, Jacob, 46

Boerhaave, Hermann, 39, 4I

Bonaly Friday Club, $\mathbf{1} 28$

Borrer, William, 96

Borthwick, Albert William, 223

Botanic Garden

distinction in terminology between

the early gardens, 13

see also

College Garden

King's Garden at Holyrood

Leith Walk Botanic Garden

Physic Garden

Royal Botanic Garden

Trinity Hospital Botanic Garden

Botanical Society Club, I22

Botanical Society of Edinburgh

founded, I 13

early progress, 115

establishes with the University the

College herbarium, I 16

transfer of the foreign collections to the Royal Botanic Garden, II7

Craig's report on the library, I I9

Library presented to the Crown, I2O

Transactions first published, I2I

Botany Building controversy, 218

Botrychium lunaria, 95

Boussingault, Jean Baptiste, I75

Bouvardia triphylla, Io9 
Bower, Alexander, quoted on George

Preston, 33

Bower, F. O., quoted on Sir J. D.

Hooker, I72

appointed to Glasgow, 176

Clarendon Press developments, 198

and Nectria cinnabarina, 2 IS

quoted on Bayley Balfour, $23 \mathrm{I}$

Boyle, Robert, 52

Brand, William, III, II3

British Ecological Society, 223

Brockie, Jean, 243, 252

Brodie, James, 96

Brown, Horace, 176

Brown, John, 6

Brown, Robert, botanist

John McKay's correspondence, 72

appointed librarian to the Linnean

Society, 93

asked to accept candidature as

successor to Rutherford, 99

work on morphology, I73

Brown, Robert, Professor of Botany, 256

Brown, Robert, nurseryman, 96

his visit to North America and

Canada, 136

Brown, William, 224

Brown, William H., 259

Brunfelsia latifolia, 70

Bulley, Arthur Kilpin, 226, 247

Burtt, Brian Lawrence, 253

Bute, Earl of, 48

C

Caenlochan Deer Forest proposed as an alpine garden, 230

Calcutta Botanic Garden, 66

Calliandra tweedii, 70

Calycantlius floridus, 84

Cambridge Botanic Garden, 48

Camerarius, Rudolf Jakob, 5 I

Campbell, Sir Ilay, I03

Campbell, James John, 247

Campbell, William Hunter

First secretary of the Botanical

Society of Edinburgh, II 3
Cardaminopsis petraea, 95

Carex atrofusca, 77

Carex limosa, 63

Carex pauciflora, 95

Carex rariflora, 77

Carex saxatilis, 77

Carex vaginata, 77

Carex vesicaria, 77

Cephalotus follicularis, 192

Cerastium alpinum, 77

Chamaepericlymenum suecicum, 95

Chandler, Bertha, 222

Charlton, Edward, II 3

Chelsea Physic Garden, 47, 93

Cherleria sedoides, 95

Chilean introductions at Logan, 272

Cicerbita (Sonchus) alpina, 77

Cinnamomum camphora, 84, 109

Circaea alpina, 95

Civil Defence, 250

Clarendon Press, 198

Clarke, Lt.-Col. Stephenson, 242

Cleghorn, William, I6 gardener to the College Garden

Clerk, Sir John, 2nd Bt., 2 I

Cochlearia alpina, 77

Cochlearia officinalis, 50

Cockburn, Henry, quoted on Mrs Rocheid, 104

Coeloglossum viride, 95

Colledge, Martin, $27 \mathrm{I}$

College Garden

transferred to Sutherland, I 3

Charles Preston appointed Keeper, 29

George Preston appointed Keeper, 30 garden abandoned, 36

Cookson, Mrs James, 26r

Cooper, Roland Edgar, Curator

succeeds Stewart, 247

Copse in Edinburgh Botanic Garden, 250, 279

Corallorliza, 95

Cordyline australis avenue at Logan, $27 \mathrm{I}$

Correvon, Henry, 216

Cowan, John Macqueen

appointed Deputy Regius Keeper, 244

publications, 244

seconded to Ministry of Supply, 25 I 
retires to join staff of National Trust for Scotland, 253

Craib, William Grant

appointed lecturer, 224

collaboration with Fletcher, 246

Craig, William, II9

Cryptogamic Society of Scotland formed, 122

Cryptograninia crispa, 95

Curtis, William, 93

Cycas circinalis, 84

Cyperus papyrus, 84

D

Dalkeith, Earl of, first President, Royal Caledonian Horticultural Society, I 38

Darwin, Charles, 174

Davidian, H. H., 245, 254

Davis, Peter H., 253, 257, $26 \mathrm{r}$

de Bary, A., I74-I76, I97-I98

de Grisebach, August, I75

de Jussieu, Antoine Laurent, 9 I

de Jussieu, Bernard

Hope's pupilage, 56

system used by McNab, 85

de Quincey, Thomas, I29

de Saussure, Théodore, 9 I

Demonstration Garden, 286

Deschampsia alpina, 77

Desmodium gyrans, 59

Dickie, George, r7 I

Dickson, Alexander, Regius Keeper, 123

original member, Scottish Alpine

Botanical Club, 123

publications, I85, 192

experience in Aberdeen, 185

Professor of Botany in Dublin and

Glasgow, 185

dispute over opening of Arboretum, I 86

Bayley Balfour's judgment on, 193

T. R. Fraser's judgment on, 193

Dickson, James, 92

visits to Scotland, 96
Dickson, Thomas

founds the Royal Caledonian

Horticultural Society, I 38

Dickson, Walter

Leith Walk Nurseries, $7 \mathrm{r}$, 85

Dicksonia antarctica planting at Logan, 271

Dillenius, Johann Jakob, 46

Don, George, principal gardener, 7r, 73

his garden at Forfar, 75

his Herbarium Britannicum, 76

his plant discoveries, 77

Donn, James, 82

Dorrien-Smith, Major, 242

Draba rupestris, 96

Dracaena draco, 84

Drummond, Thomas, 96

Dryas, 95

Drysdale, Daisy, 252

Dublin, Trinity College Physic Garden, 48

Duncan, Andrew, Jnr., Ioo

Duncan, James, 239

E

Edinburgh Castle

Sutherland and the siege of I689, Is

Arthur and the siege of I7I 5, 2I

Edinburgh Town Council

leases Trinity Hospital Garden, 7

assists Preston's restorations at Trinity, 33

awards Alston a salary, 40

appoints Rutherford, 68

Botanical Society's petition on

accommodation, II 8

considers claims of Balfour and

Hooker, 126

purchases Inverleith, I 8 I

complains at Dickson's failure to open

the Arboretum, I 88

Botany Building action, 218

Edinburgh University

Town's Chair of Botany, I2

Hope's re-organisation of the Chairs, 58

Principal Baird's explanation of the

joint posts, IoI 
College and Botanical Society

herbaria combined, I I6

Universities Commission, $\mathrm{x} 862$, 184

transfer of Garden to University

control resisted, 200

Curators' Chair transferred to the

Crown, 205

new Department of Botany, I9Io, 218

Robert Brown succeeds Smith as

Regius Professor, 256

Taxonomy Diploma course, 257

Department of Botany's move to

King's Buildings, 269

Edinburgh Workers' Educational

Association, 223

Edwards, Sydenham, 93

Epidendrum (grahamii) phoenicium, 109

Erigeron borealis, 96

Eriocaulon, 95

Eriocaulon septangulare, 63

Erysimum perofskianım, 109

Eudall, R., 254

Euphorbia esula, 62

Euryale ferox, 85

Eurycles sylvestris, 84

Evans, A., 270

Evans, William, 22 I

Evans, William Edgar

succeeds Jeffrey, 22 I

retires, 252

Evans, William Wilson, $\mathrm{r}_{4} \mathrm{r}$

Exhibition Hall, r40, 258, 29I

\section{F}

Falconer, David, $x_{4} 4$

Farlow, W. G., 175

Farrer, Reginald, 215

Ferula asafoetida, 63

Fettes Trust

negotiations in 1874,178

extensions for forest nursery, 237

Fletcher, Harold Roy, Regius Keeper

collaboration with Smith, 242

appointed to succeed Tagg, 245

collaboration with Craib, 246

Director of Wisley Gardens, 253 returns as Deputy Regius Keeper, 254

succeeds Smith, 256

Foister, Charles, 240

Forbes, Edward, I I 3, I25

Forestry Commission

nursery at the Royal Botanic Garden, 236

jurisdiction at Benmore, 239

Forrest, George

appointed to Herbarium staff, 22I

leaves for China, 226

death, 245

herbarium collections, 260

Forsyth, William, 92

Fortune, Robert, I56, 271

Fothergill, John, 4I

Fothergilla, 42

Franscicia latifolia, 70

Fraser, Thomas R., quoted on Dickson, 193

Fries, Elias, 9x

G

Gardener, Walter, I76

Gardoquia multiflora, I09

Geddes, Patrick, 199

Gentiana nivalis, 96

Gerard, John, 48

Gibson-Craig, Sir William, I4I, 147

Gilbert, J. H., I75

Giseke, Paul Dietrich, herbarium collection, 260

Glasgow Botanic Garden

Hopkirk collections, 96

established under Graham, 103

Balfour's improvements, 197

Glasgow University

Graham appointed Regius Professor

of Botany, 96

W. J. Hooker appointed Professor of

Botany, Glasgow, I69

Dickson appointed Regius Professor of Botany, I85

Bayley Balfour appointed Regius

Professor of Botany, 197

Glasnevin Botanic Garden, 70 


\section{Glasshouses}

first in use at Trinity Hospital, 34 at Leith Walk site of Botanic Garden, 59

their ruinous state in 1808,79

Graham's improvements at Inverleith, I09

Palm House opened, 1834, 109

James McNab's experiments, I36

Balfour's restorations, I 858 , I4 I new Palm House opened, 143 condition of glass in I 890, 207 reconstruction, $1893,2 \mathrm{I} 2$ new main range constructed, 1898,2 I 4 demolition, I965, 263

design and construction of new range, 263

sound guides, 285

description of new range, 288

Glenbranter proposed as an arboretum, 237

Goodyera, 95

Goodyera repens, 62

Gorton

Charles Preston's private botanic garden, 28

Graham, Robert, Regius Keeper Professor of Botany in Glasgow, 96 succeeds Rutherford in Edinburgh, $\mathrm{IO} 2$

publications, 108

transference of Botanic Gardeu to Inverleith, 104-I08

improvements at Inverleith, I09

his methods of teaching, I Io

his excursions, II I

elected first President of the Botanical Society, II4

Graham, H. G., quoted on condition of universities in Scotland, xiv

Graham, Robert James Douglas, 235

Gray, Asa, 175

Greville, Charles Francis, 92

Greville, Robert Kaye excursions with Graham, I I I founder member of Botanical Society, I I 3 herbarium collection, I 58,260
Grew, Nehemiah, 53

Grierson, A. J. C., 254

Grieve, James, 216

Gronoviuss, Johann Friedrich, 42

\section{$\mathrm{H}$}

Hales, Stephen, 53

Hall, A., 274

Hambro, R. O., 27I

Harrow, Robert Lewis, Curator foreman of glass department, 204 succeeds Richardson as Curator, 2 I I director of Wisley Gardens, 246

Harvey, William Henry, I25 succeeded in Dublin by Alexander Dickson, I85

Hay, Alexander, apothecary, 3 I

Headfort, Lord, 242

Heather garden established, 248

Hebe $\mathrm{x}$ lindsayi, 192

Hedge, I. C., 254

Henderson, Alexander, IOI

Henderson, D. M., 254 completes Wilson's work, 225

Henry, Augustine, 226

HM Queen Elizabeth II opens new building, 26I

HRH Princess Margaret, Countess of Snowdon, opens new glasshouse, 268

Herbarium

Botanical Society's formed, II S Society and University collections, combined, II 7 transfer to Inverleith, I I 8 Keeper appointed, 209 administration in 1890,209 Jeffrey appointed assistant, 22 I Evans succeeds Jeffrey, 22I new accommodation, 1964, 259

Hieracium alpinum, 95

Hieracium lingulatum, 77

Hill, Sir Arthur, 29I

Hill, John, 5I

Hofmeister, Wilhelm, 174

Holford, Sir George, 242 


\section{Holyrood Abbey \\ Sutherland's lease of the King's \\ Garden, 13}

Alston appointed overseer, 38

proposed as site of new garden, 1820 ,

IO4

see also Physic Garden

Home, Francis, 58

Hooke, Robert, 52

Hooker, Sir Joseph Dalton

deputises for Graham, I I I, I2S

candidate for the Edinburgh Chair, I26

appointed botanist to the Geological

Survey, I72

publications, $\mathrm{I} 72$

supports Bayley Balfour for Aberdeen

Chair, I96

Hooker, Sir William Jackson

Graham's contributions to Botanical

Magazine, 109

influence at Glasgow, II I, I69

appointed to Kew, I7I

Hope, John, Regius Keeper, 56

Professor of Botany, 58

secures new site for Botanic Garden, 59

secures permanent endowment for

Botanic Garden, 59

physiology experiments, 60

studies in Scottish flora, 6 I

Hopea, 67

Hopkirk, Thomas, 96, I03

Hortus Medicus Edinburgensis, I I

Hoy, James, 96

Hudson, William, 94

Humbolt, Alexander von, 91

Hutchinson, John, 243, 245

Huxley, T. H., 175, 196, 198

Hymenophyllum, 95

Hypericum, 262

I

Illiciun anisatum, 59

Ingen-housz, John, 60, 94

International Botanical Congress, 26I

Inverewe Gardens, 253

\section{Inverleith House \\ gardens described, ros \\ grounds acquired as site for \\ Arboretum, I48 \\ Regius Keeper's residence, I7 8 \\ partly destroyed by fire, I 8 I \\ conversion into Gallery of Modern}

Art, 256

Isoetes, 95

Isolobus corymbosus, I09

$\mathrm{J}$

Jeffrey, John, I36

his plant introductions, I 37

Jeffrey, John Frederick, 22I

Jenner, Charles, 123

Johnson, Thomas, 49

Johnstone, George, 242

quoted on Species of Rhododendron, 243

Johnstone, James Todd, 222, 2\$2

Juglans regia, 34

Juncus biglumis, 77

Juncus bulbosus, 77

Juncus castaneus, 77

K

Keenan, J., 254

Kellerman

Assistant Curator of the Botanical

Society, II6

Kemp, Edward Edmund, Curator

foreman, Propagation Department,

247

war-time service, $25 \mathrm{I}$

appointed Curator, 253

Kenyon, Roger, 25

Kerr, William, 92

Kew, see Royal Botanic Gardens, Kew

Kingdon-Ward, Frank, 245

King's Botanist

Post instituted, I6

King's Garden at Holyrood, I3

Knight, Thomas Andrew, 94 
L

Lamont, Charles, 247

Latlyrus niger, 96

Lauder, Sir John, xv

Lawener, L. A., 254

Lavatera arborea, 50

Lawes, J. B., I75

Lecuwenhock, Anthoni van, 52

Leiden

Alston a student at, 39

Leith Walk Botanic Garden site acquired by Hope, 59 its sudden decline I809-I 810, 79

transferred to Inverleith, I05

Leith Walk Linnean Society, 86

Library

Dr Craig's report to the Botanical Society, II 9

presented to the Crown, I20

Johnstone appointed Librarian, 222 new accommodation, 1964, 259

Lightfoot, John, 6I

collections in Scotland with Pennant, 94

Ligusticum scoticum, I0

Lindsay, Robert, Curator, I9I awarded Neill Prize, 192

Lindsay, William Lauder, I 50

Linklater, Eric, quoted on the rise of botany in Edinburgh, xvi

Linnaea borealis, 96

Linnacus, Carolus, 62

Alston repudiates his 'sexual system', 42

Hope's advocacy of, 6I monument erected by Hope, 64 relocation of monument at Inverleith, Is 6

Linnean Society, founded I 788, 93

Linsell, Edna L., 243, $2 \$ 2$

Livingston

Murray's botanic garden, 6

Lobelia coronopifolia, 109

Lobelia nubigena, 247

Loder, Sir Edmund, 242

Logan Botanic Garden first peat garden created, 249 described, 270

Loiseleuria procumbens, 62

Ludlow, Frank, 245, 246

Luzula arcuata, 77

Lychnis viscaria, I0, 50, 77

Lycopodium alpinum, 50

Lynch, R. I., 2I2

M

McCoig, Malcolm, principal gardener, 64

McDouall, Kenneth and Douglas, 242, 249, $27 \mathrm{I}$

MacGillivray, William, 170

McKay, James Townsend, 7I, 73

McKay, John, principal gardener, 7I

MacKenzie, William Gregor, 247

Maclagan, Andrew Douglas, I 8

Maclaren, John, I 50

Macleod, Reginald, 205

McNab, Gilbert, II 3

$\mathrm{McNab}$, James, principal gardener founder member of Botanical

Society of Edinburgh, II 3

appointed Curator to the Botanical Society, II4

succeeds his father as Principal

Gardener, 135

his visit to North America and

Canada, 136

his work for Royal Caledonian

Horticultural Society, I 39-I4I

his work at Botanic Garden, I4I-I47,

I 57

publications, I45, I63

his tree lifting machine, I 57

his description of the Rock Garden, I 59

landscape gardening and town

planning activities, 163

President of Botanical Society, I63

McNab, William, principal gardener, 80

his work at Leith Walk Botanic

Garden, 84

presents a Memorial, 87 
his transplanting operations at

Inverleith, I05

publications, 108

founder member, Botanical Society of

Edinburgh, II 4

testimonial dinner, I 34

Macvicar, S. M., I2I

Magnolia coco, 84

Malpighi, Marcello, 52

Mandevilla suaveolens, 70

Mar, John Erskine, Earl, 24

Marshall, J. M., 270

Martyn, John, 48

Martyn, Thomas, 49

Masson, Francis, 92

Matthews, James Robert, v, 235

Maugham, Robert, II4

Maxwell, Helen T., 245

Maxwell, Sir Herbert, 242

Maxwell, Sir John Stirling, 242

Mendel, Gregor, 94

Menzies, Archibald, 66

Menzies, Robert, principal gardener, 69

Menziesia, 66

Mertensia maritima, 50

Miller, Charles, 49

Miller, Helen T. (née Maxwell), 245, 252

Miller, Philip, 36, 43, 47

Minuartia rubella, 77

Mohl, Hugo von, 173

Moneses uniflora, 96

Monro, Alexander, 40

Moore, Sir Frederick, 242

Morison, Robert, 3, 46

Morland, Walter, 2 I7

Morton, Earl of, IoI

Muirhead, C. Winsome, 254

Munby, Giles, II3

Murchison, Charles, I 50

Murray, Alexander, 96

Murray, Patrick, 6

Murray, Stewart, I03

Museum

established, I42, I 49

enlargement recommended, 209

Tagg appointed assistant, 220

Myosotis alpestris, 77
$\mathrm{N}$

Naegeli, C. von, 173

Nandina domestica, 84

Neill, Patrick

recommends Don to J. E. Smith, 7I

on John McKay, 72

visits Don at Forfar, 74

notes state of Leith Walk garden, 79, 84

comments on superintendent's salary, $8 \mathrm{I}, 85$

encourages Robert Brown to apply as

Rutherford's successor, 99

founder member of the Botanical

Society of Edinburgh, I I 4

Secretary of the Royal Caledonian

Horticultural Society, 138

Neill Prize, Royal Caledonian Horticultural Society

awarded to Sadler, 146

awarded to Lindsay, I92

awarded to Richardson, 205

Nelson, Alexander, 236, 256

Nelumbo nucifera, 85

Nepenthes cultivated by Lindsay, I9I

New Botany, the, 176

Nicholson, Henry, 48

Notes from the Royal Botanic Garden, 263

Nuphar micropliylla, 85

Nuphar pumila, 96

Nympliaea lotus, 84

Nymphaea rubra, 84

Nymphaea stellata, 84

$\mathrm{O}$

Oliver, David R., 252

Ononis reclinata, I I I

Oregon Association, I 36

Orr, Matthew Young, 222, 252

Oxford University

Morison first professor, 3,46

Physic Garden, founded, 1621,46

Balfour appointed Sherardian

Professor, 198

Oxytropis campestris, 77 
$\mathrm{P}$

Palmerston, Lord, 167

Parnel, Richard, I I3

Paterson, Robert, I5O

Pearce, G. A. H., 265

Peat Garden

established in Edinburgh, 249

described in 1970,284

at Logan, 249, 272

Pennant, Thomas, 94

Persoon, Christiaan Hendrik, 9I

Phyllodoce caerulea, 96

Physic Garden

Holyrood site, 6

Sutherland acquires Trinity Hospital

site for extension, 7

plants grown in $\mathrm{I} 683$, II

flooding in 1689 , Is

first glasshouse erected, 34

plants grown in $\mathrm{I} 7 \mathrm{I} 2,34$

plants transferred to Leith Walk, 59

Physicians [Royal] College of

Sibbald's Presidency, 5

disciplines Preston, 27

Preston appointed Secretary, 28

Alston appointed Secretary, 39

Picea sitcliensis, $\mathrm{I} 37$

Picea sitchensis stand at Benmore, 275

Pinguicula lusitanica, 95

Pinus balfouriana, $\mathrm{I} 37$

Pintus contorta, $\mathrm{I} 37$

Pinns contorta var. latifolia, I37

Pinus jeffreyi, $\mathrm{I} 37$

Pinus ponderosa, $\mathrm{I} 37$

Pitcairn, Archibald, xv, 28

Plant physiology

Hope's experiments, 60

Plummer, Andrew, 40

Poa alpina, 62

Poa $\times$ jemtlandica, 77

Polygonum viviparum, 95

Polystichum lonchitis, 95

Pothocites grantonii, 150

Prain, Sir David

recommends Wright Smith as

Director, Royal Botanic Garden,

Calcutta, 226 quoted on Bayley Balfour, 230

Prentice, Heather T., 254

Preston, Charles, 26

appointed Professor of Botany, I8, 29

correspondence, 27,30

published work, 30

Preston, George, 30

appointed Intendant of the Botanic

Garden, 30

appointed Surgeon-Major, 3 I

appointed Professor of Botany, 32

erects first glasshouse in $17 \mathrm{r} 3,34$

publishes list of plants in Garden, I7I2, 34

Prestonia, 27

Priestley, Joseph, 69

Priestley, Sir W. O., I 50

Primrose, H. W., 205

Primula scotica, 63

Pringsheim, Nathanael, I75

Prioria, II3

Probationers see Student Gardeners

Prinus malialeb, 84

Pseudotsuga menziesii, I 37

Pseudotsuga menziesii stand at Benmore, 275

Public Building and Works, Ministry of, 203

designs new buildings, 258,265

transfers control of Garden, 29I

Puck's Glen memorial to Bayley

Balfour, 239

Purves, Dorothea E., 252, 254

Pyrola minor, 95

Pyrola secunda, 95

Q

Quacaplesink, I04

Quercus suber, 34

$\mathrm{R}$

Ramsden, Sir John, 242

Ransford, Charles, quoted on Graham's teaching, IIO 
Ranunculus reptans, 62

Ratter, J. A., 260

Ray, John

his visit to Scotland, 49

contributions to botany, $5 \mathrm{I}$

Rehder, Alfred, 243

Reid, George F., 252

Rheum palmatum, 63

Rhododendron introductions, 276

Rhododendron Society, 227, 242

Rhododendron Walk in Edinburgh

Botanic Garden, 280

Rhododendron 'William Wright Smith', 243

Richardson, Adam Dewar, Curator, 204 awarded Neill Prize, 205

Roberts, Jack, 249

Rocheid, James, 104

Rocheid, Mrs, $\mathrm{IO}_{4}$

Rock Garden

begun, I59

Farrer's criticism, 215

reconstruction, 215

Correvon's enthusiasm, 216

moraine constructed, 246

its description in $1970,28 \mathrm{r}$

Rock, Joseph, 245

Rodriguez expedition, 196

'Rooteries', 249

Rothschild, L. de, 242

Roxburgh, William, 65

Royal Botanic Garden

first Inverleith site selected, I04

new classroom and museum opened, 142

acquires the Royal Caledonian

Horticultural Society's garden, $x 47$

its description in 1870,149

Queen's Views, I57

Rock Garden under construction, I 59

Sunday opening, I64, I86, 203

extension for Arboretum acquired, I80 extensions transferred to $\mathrm{HM}$

Commissioners of Works, I $8 \mathrm{r}$

dispute on opening of Arboretum, 186 new lecture hall, 193

transfer to University resisted, 200

final vestiture as Crown property, 203 committee of enquiry into

organisation, I890, 205

Botany Building controversy, 2 r8

war-time conditions, 250

present staff, 254, 260, 270

new buildings, 256-269

Plant Propagation Department

reorganised, 257

its description in 1970,270

see also

Arboretum

Demonstration Garden

Herbarium

Library

Glasshouses

Heather Garden

Rock Garden

Logan Botanic Garden

Younger Botanic Garden

Peat Garden

Woodland Garden

Rhododendron Walk in Edinburgh

Copse in Edinburgh

Royal Botanic Garden Guild, 2 I7

Royal Botanic Gardens, Kew, established, 48

John Smith appointed Curator, 90

Royal Botanic Institution of Glasgow, I03

Royal Caledonian Horticultural

Society, 104

founded, $\mathrm{x}_{3} 8$

acquires garden at Inverleith, 139

the Winter Garden, I39

Exhibition Hall, I40, 258

transfers its garden to the Office of Works, I 47

Royal High School botany classes, I 46

Royal Horticultural Society

foundation, 92

Bayley Balfour's Masters Memorial

Lectures, 228

Bayley Balfour's award of Victoria

Medal of Honour, 229

Primula Conference, 1928, 242

awards to Cowan, 253

awards to Smith, 254

see also Rhododendron Society 
Royal Scottish Arboricultural Society, 205

Royal Society of Edinburgh founded, II4

Rutherford, Daniel, Regius Keeper, 68 correspondence with Banks, 80

Rutherford, John, 9, 40

\section{S}

Sabbath Alliance, The, 164

Sachs, F. G. J. von, 174-176, I98

Sadler, John, Curator original member Scottish Alpine Botanical Club, I23

lecturer at Royal High School, 146 appointed Balfour's assistant, I46 awarded Neill Prize, I46 succeeds $\mathrm{McNab}, \mathrm{I} 82$ curator of arboretum, I 87 Bayley Balfour's judgment, 190

Saddler, R., 258

Sagina saginoides, 77

Salaries and wages, I890, 210

Salisbury Crags proposed as a rock garden, $\mathrm{IO}_{4}$

Salix herbacea, 95

Salix lanata, 96

Saxifraga cermua, 96

Saxifraga oppositifolia, 77, 95

Saxifraga rivularis, 77

Schenck, H., I75

Schimper, A. F. W., I75

Schleiden, M. J., I73

Scloenus ferruginens, 63

Scott, D. H., I76

Scott, Sir Walter, account of I7IS plot to capture Edinburgh Castle, 22

Scottish Alpine Botanical Club, I23

Scottish flora

finds of Ray and Willisel, so

pioneering by Hope, 6r

McKay's contributions to English

Botany, 7I

Don's collections, 74

work of the Leith Walk Linnean

Society members, 86
William McNab's collecting, 89

Lightfoot and Pennant's tour, 94

Hopkirk's Flora Glottiana, 96

Graham's excursions, Iro

work of the Botanical Society, II 3 ,

120

Balfour's expeditions, I33

Hooker's Flora Scotica, I 69

work of MacGillivray and others, 170

finds of Sadler and Lindsay, 190

Scottish Gallery of Modern Art, 256

Sequoiadendron giganteum avenue at

Benmore, 275

Shaw, Richard Lendrum, 273

Sherard, William, 35,46

Sherriff, George, 245-6

Sibbald, Sir Robert, xv, 3-Io

publishes Scotia Illustrata, 8

Sibbaldia procumbens, ro

Sibthorp, Humphrey, 47

Silene acaulis, 95

Silene maritima, so

Sinclair, Andrew, 40

Sisymbrium irio, 50

Sloane, Sir Hans, I 8, 27, 47

Smith, James Edward

on Cambridge Botanic Garden, 48

recommends Don as curator, 73

foundation of Linnean Society, 93

McKay's contribution to English

Botany, 72

suggested as Rutherford's successor, 102

Smith, James Lindsay Salmond, 225

Smith, John, Curator, Royal Botanic

Gardens, Kew, 89

Smith, Rosemary M., 254

Smith, William Gardner, 223

Smith, Sir William Wright, Regius

Keeper

appointed assistant to Bayley Balfour, 225

service in India, 226, 24I

succeeds Bayley Balfour, 233

association with Forestry Commision, 236

association with Board of Agriculture, 240 
publications, 24I

collaboration with Fletcher, 242

honours, 254

Snoddy, A., 270

Socotra, Bayley Balfour's expedition to, 197

Sommerville, Thomas, principal gardener, 78

Sound guide tour of glasshouses, 288

Sowerby, James, 93

Sparganium, 95

Sprengel, Christian Konrad, 9I

Spruce, Richard, I2 I

Stair, Lord, 242

Steuart, David, I I 4

Steuart, Sir Henry, Io6

Stewart, Laurence Baxter, Curator, 228, 235

Stott, Ella R., 252

Student gardeners' course introduced, 216

Sunday opening of Botanic Garden, 164, I 86,203

Surgeons [Royal] College of apprentices instructed by

Sutherland, I6

Charles Preston's petition for the post of instructor, 28

George Preston appointed instructor, 32

Sutherland, James, Regius Keeper appointed Intendant, 7 publishes Hortus Medicus

Edinburgensis, I I

Professor of Botany, I2

King's Botanist, I4, I6

Regius Professor of Botany, I4

resigns his appointments, I7

correspondence, I8

Sttherlandia, 19

$\mathrm{T}$

Tagg, Harry Frank

appointed Museum Assistant, 220

contributions to Species of

Rhododendron, 243
Taxonomy, its significance, 262

Thalictrum alpinum, 77, 95

Thiselton-Dyer, William Turner, 176 , I98, 205, 230

Thomson, Sir Wyville, I76, I96

Thuja orientalis, 84

Thuja plicata stand at Benmore, 275

Tofieldia pusilla, 50, 95

Trachycarpus fortunei, I 56

Trachycarpus fortunei avenue at Logan, 27 I

Trail, James, I97

Treasury report on Botanic Garden, 205-2I I

Tree transplanting, I05, I44, I 57, 268

Trichophorum alpinum, 62

Trinity Hospital Botanic Garden site acquired, 7

George Preston's leases, 32, 35

first glasshouse, 34

Sutherland's catalogue of plants, 7

Charles Preston's catalogue, 34

plants transferred to Leith Walk, 60 garden flooded, I5

Tsuga heteropltylla, I 37

Tsuga heterophylla stand at Benmore, 275

Tsuga mertensiana, I 37

Tübingen Botanic Garden, SI

Tulasne, Louis René and Charles, I74

Tweedia, 70

Tweedie, John, 70

Tyacke, Nicholas, I I 3

U

Universities (Scotland) Act, 1889, 200, 2 I 8

Utricularia minor, 95

V

Vaccinium uliginostm, 95

Van Tieghem, I74

Veitch, Messrs, 227

Verbena, 70

Veronica alpina, 62 
Veronica fruticans, 96

Victoria, 289

Vines, Stanley, I76, 198

\section{W}

Walker, John, 5

Walker, Richard, 49

Walker-Arnott, George Arnold, I I4, I7 I

succeeded in Glasgow by Dickson, I 85

Wallich, George Charles, II 3

Ward, Harry Marshall, I 76, 198

Warming, E., I75

Watling, R., 260

Watson, Hewett Cottrell, I I I, I70 publications, I70-I 7I

Wauchope, John of Hill, 3 I

Wedgwood, John, 92

Wernerian Natural History Society, I I 4

Westergaard, Emil, 22 I

Wilkie, David, 247, 252

Willdenow, Carl Ludwig, 9I

Williams, John Charles, 227, 242

Williamson, John, principal gardener, 64

Hope's memorial tablet, 64, I 5 I

Williamson, William Crawford, $\mathbf{I} 76$
Willisel, Thomas

contributions to British flora, 50

Willughby, Francis, $5 \mathrm{I}$

Wilson, Ernest Henry, 227

Wilson, Malcolm, 224

Winch, Nathaniel, I70

Wodrow, Robert, I 8

Wood, Andrew, IO2

Wood, Robert, gardener to George

Preston, 36

Woodland Garden and Copse in

Edinburgh

developed from Arboretum, 249

Woodland Garden described, 278

Woods, P. J. B., 254

'Working Men', The, I64

\section{Y}

Yew, Sutherland's, I56, 268

Younger Botanic Garden

Benmore first considered, 230

presented to the nation, 239

success of Sino-Himalayan material, 250

described, 273

Younger, Harry George, 239 

11451 



$$
11451
$$




\section{(C) Crown Copyright 1970}

Published by

Her Majesty's Stationery Office

To be purcliased from

13 a Castle Street, Edinburgh EH2 3 AR 49 High Holborn, London wCI 109 St Mary Street, Cardiff CF1 i JW Brazennose Street, Manchester M60 8AS so Fairfax Street, Bristol BSI 3DE 258 Broad Street, Birminghamn I 7 Linenlall Street, Belfast BT2 8 AY or through any bookseller

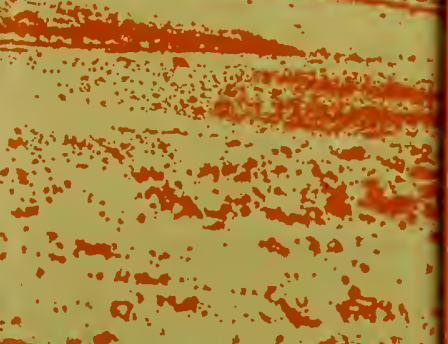


$-\frac{1}{2}$

i.

2.

it:-

jost

toring

a.

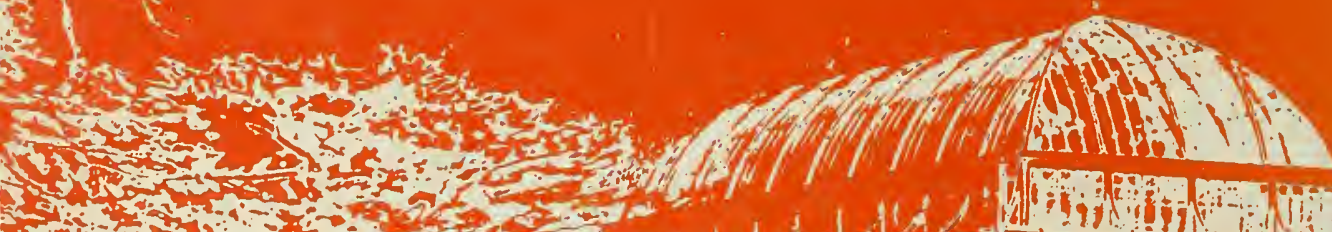
(1)

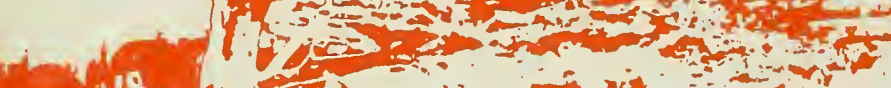

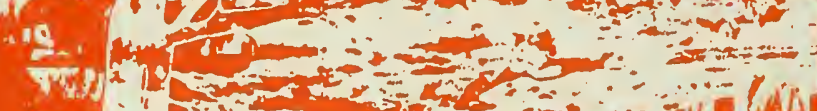

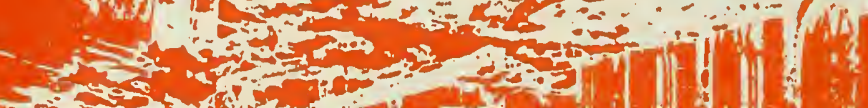

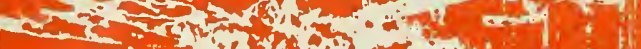

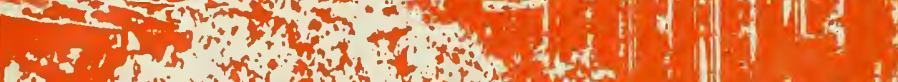
and (3) mand mand

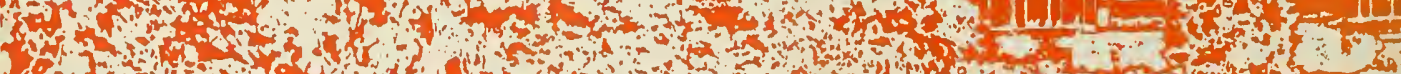

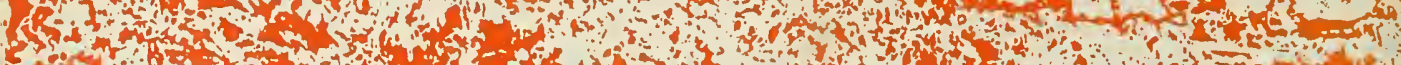

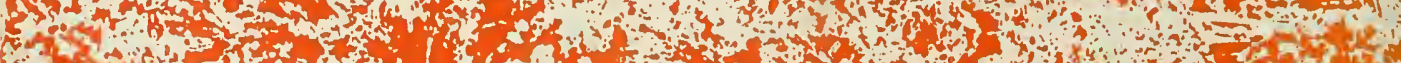

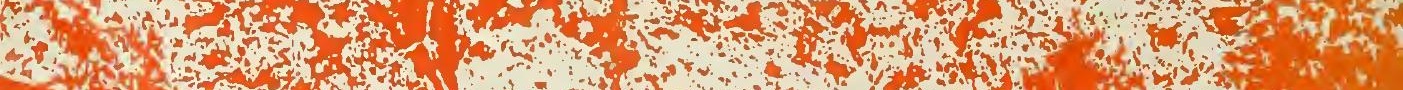

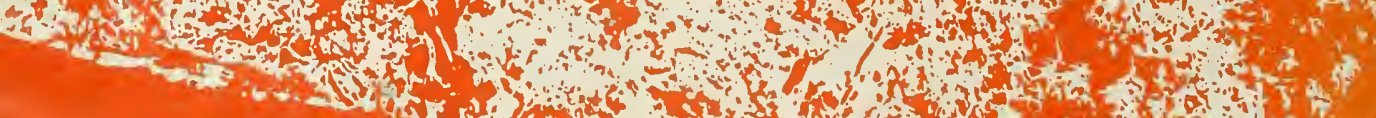

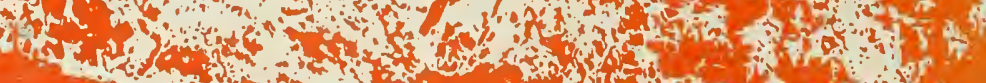

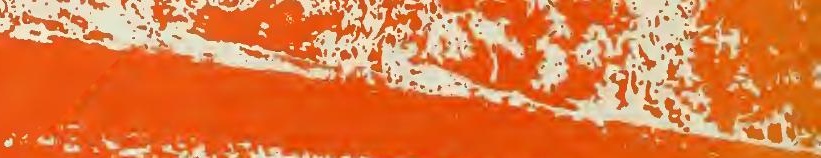

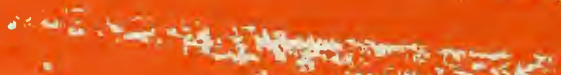

d.

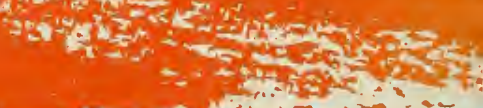

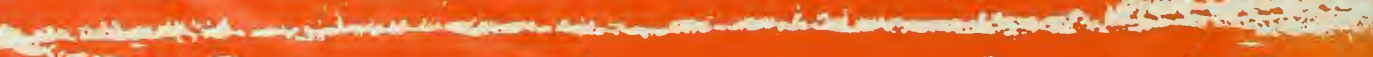

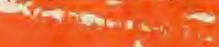

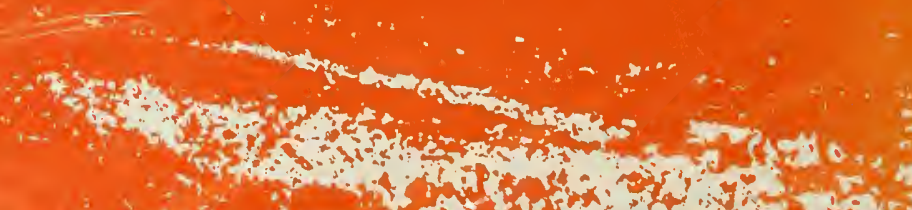

